\title{
Combined Heat and Power Market Potential for Opportunity Fuels
}

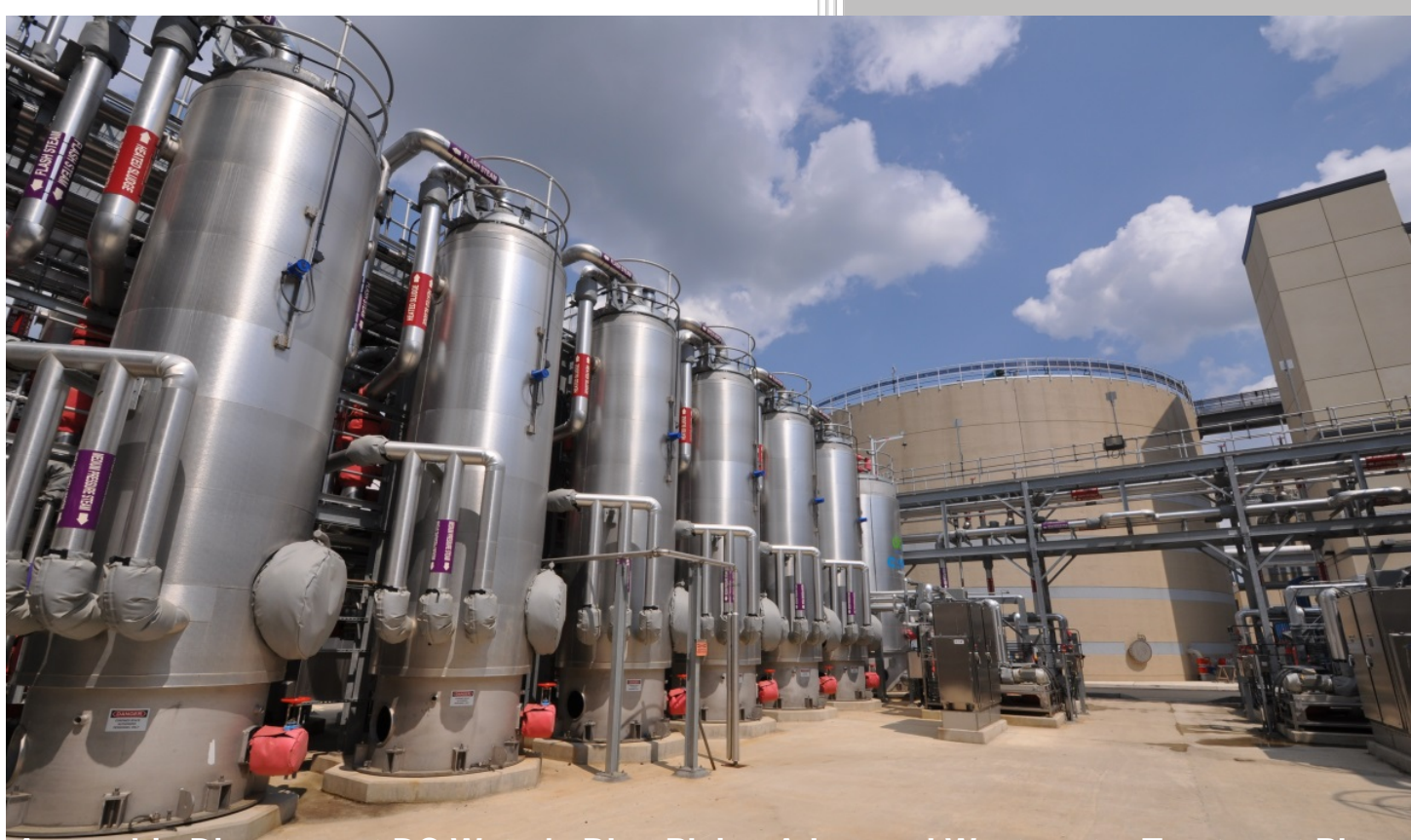

Anaerobic Digesters at DC Water's Blue Plains Advanced Wastewater Treatment Plant

Source: DC Water

\section{Approved for public release.} Distribution is unlimited.
David Jones

Paul Lemar

Resource Dynamics Corporation

December 2015 


\section{DOCUMENT AVAILABILITY}

Reports produced after January 1, 1996, are generally available free via US Department of Energy (DOE) SciTech Connect.

Website http://www.osti.gov/scitech/

Reports produced before January 1, 1996, may be purchased by members of the public from the following source:

National Technical Information Service

5285 Port Royal Road

Springfield, VA 22161

Telephone 703-605-6000 (1-800-553-6847)

TDD 703-487-4639

Fax 703-605-6900

E-mail info@ntis.gov

Website http://www.ntis.gov/help/ordermethods.aspx

Reports are available to DOE employees, DOE contractors, Energy Technology Data Exchange representatives, and International Nuclear Information System representatives from the following source:

Office of Scientific and Technical Information

PO Box 62

Oak Ridge, TN 37831

Telephone 865-576-8401

Fax 865-576-5728

E-mail reports@osti.gov

Website http://www.osti.gov/contact.html

This report was prepared as an account of work sponsored by an agency of the United States Government. Neither the United States Government nor any agency thereof, nor any of their employees, makes any warranty, express or implied, or assumes any legal liability or responsibility for the accuracy, completeness, or usefulness of any information, apparatus, product, or process disclosed, or represents that its use would not infringe privately owned rights. Reference herein to any specific commercial product, process, or service by trade name, trademark, manufacturer, or otherwise, does not necessarily constitute or imply its endorsement, recommendation, or favoring by the United States Government or any agency thereof. The views and opinions of authors expressed herein do not necessarily state or reflect those of the United States Government or any agency thereof. 


\title{
COMBINED HEAT AND POWER MARKET POTENTIAL FOR OPPORTUNITY FUELS
}

\author{
Resource Dynamics Corporation \\ 7921 Jones Branch Drive \\ McLean, VA 22102 \\ 703-356-1300 \\ www.rdcnet.com
}

Date Published: December 2015

\section{Prepared by}

OAK RIDGE NATIONAL LABORATORY

Oak Ridge, Tennessee 37831-6283

managed by

UT-BATTELLE, LLC

for the

US DEPARTMENT OF ENERGY

under contract DE-AC05-00OR22725 



\section{CONTENTS}

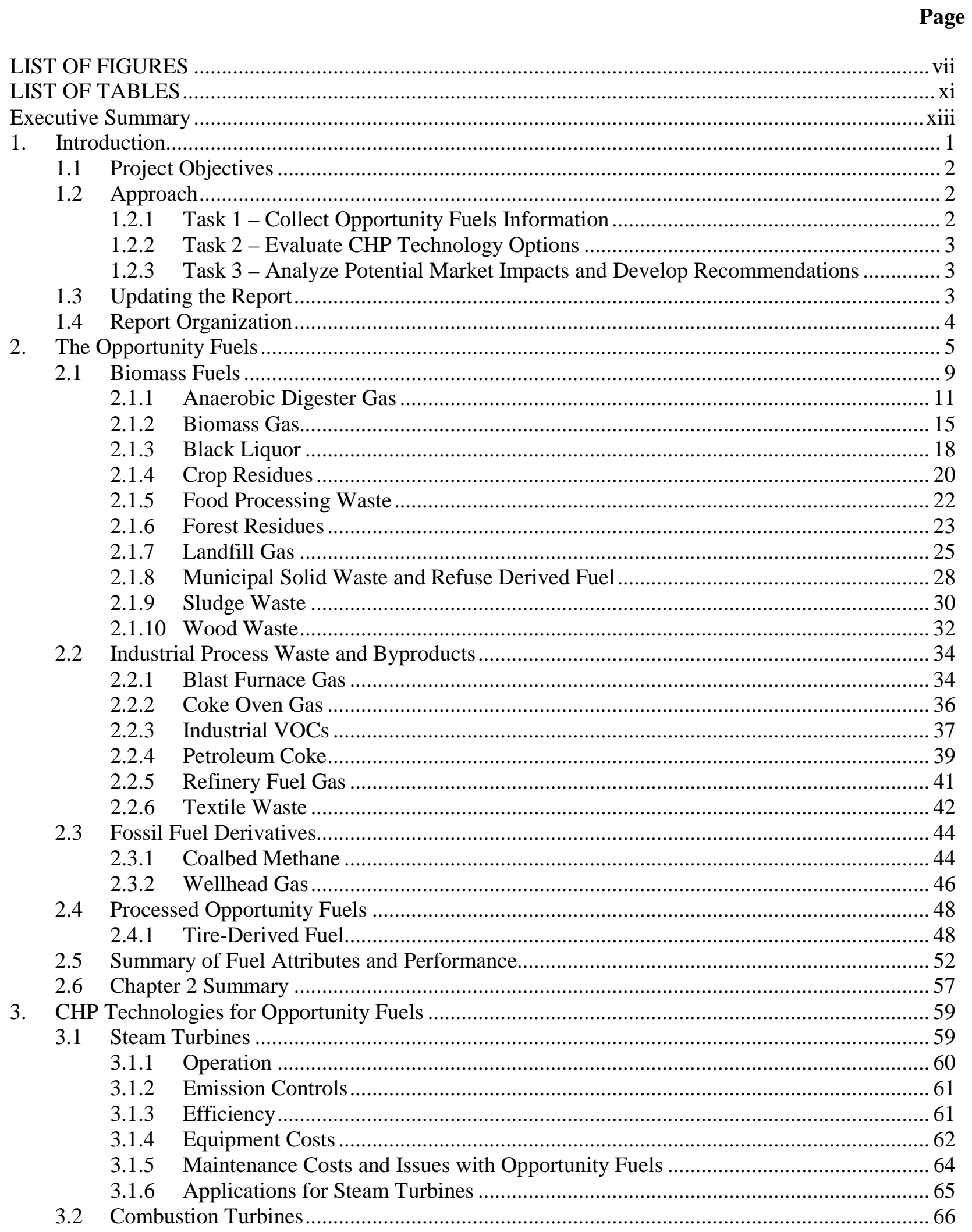




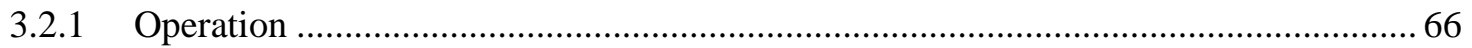

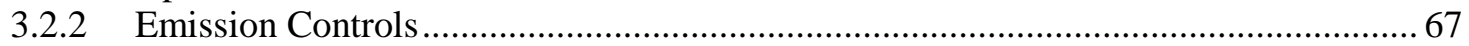

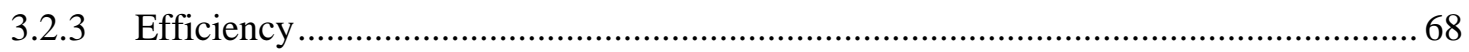

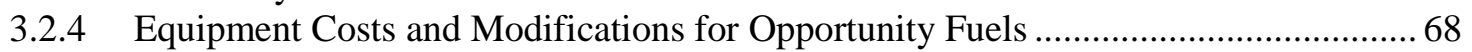

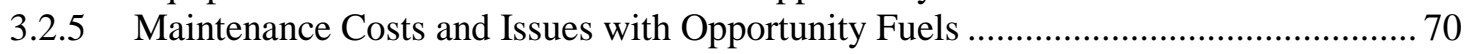

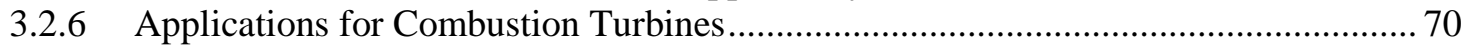

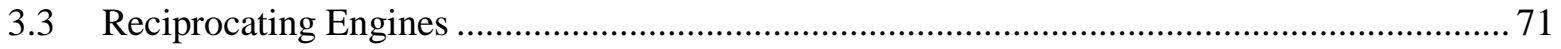

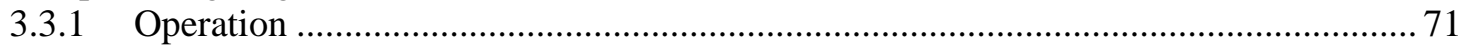

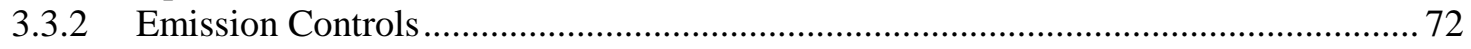

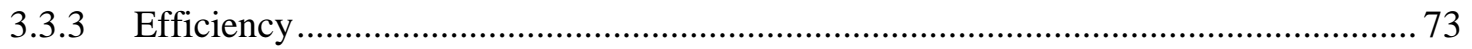

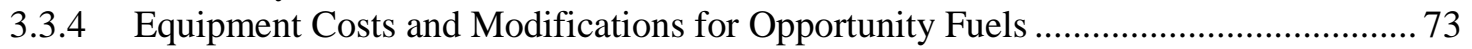

3.3.5 Maintenance Costs and Issues with Opportunity Fuels .............................................. 74

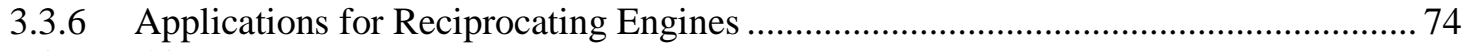

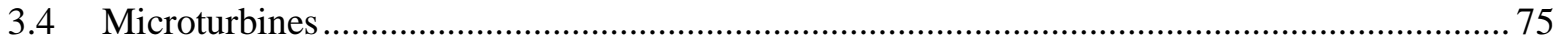

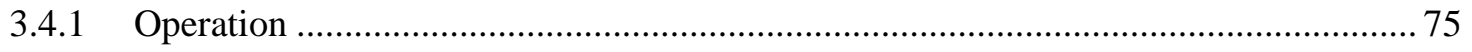

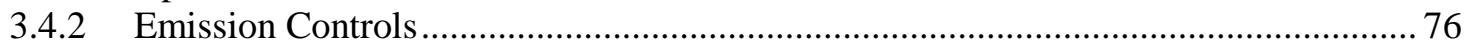

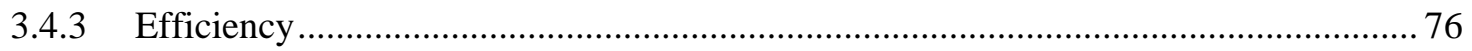

3.4.4 Equipment Costs and Modifications for Opportunity Fuels ...................................... 76

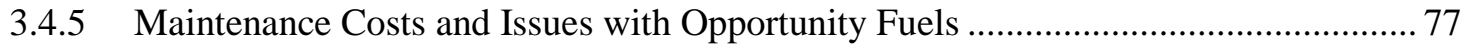

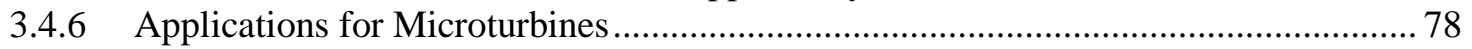

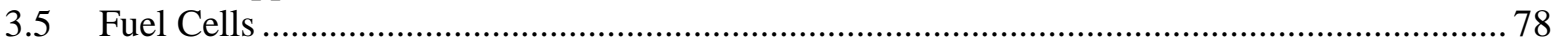

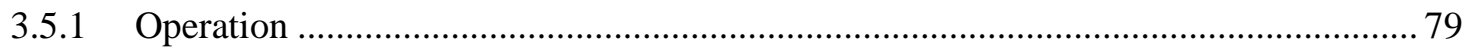

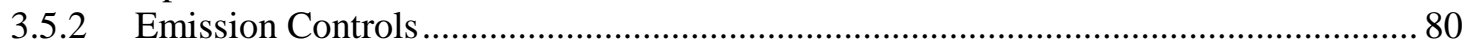

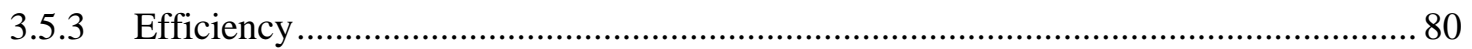

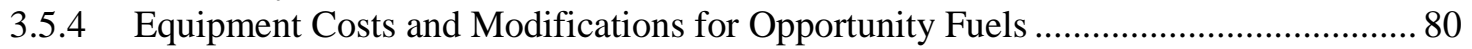

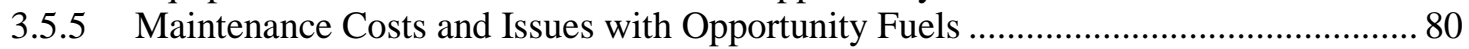

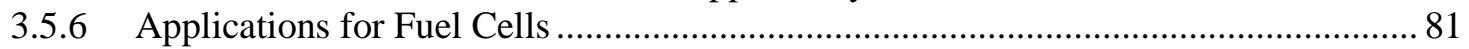

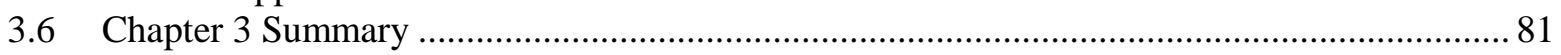

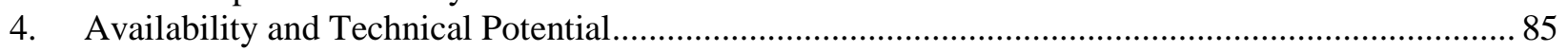

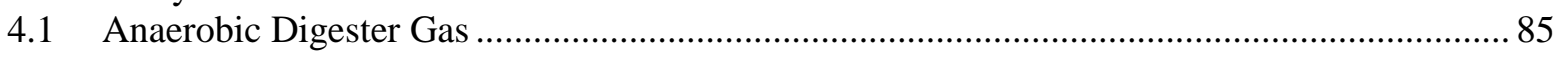

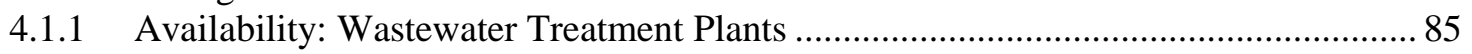

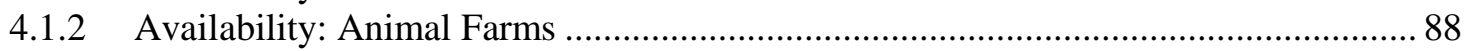

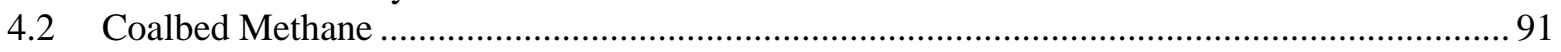

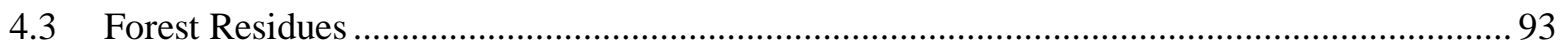

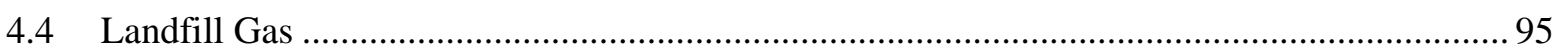

4.5 Tire-Derived Fuel................................................................................................. 97

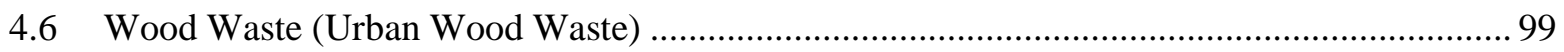

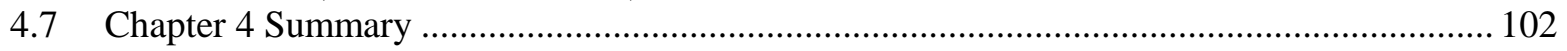

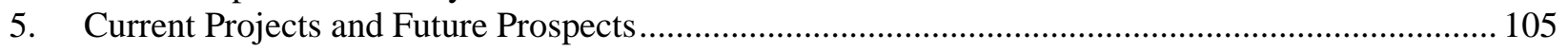

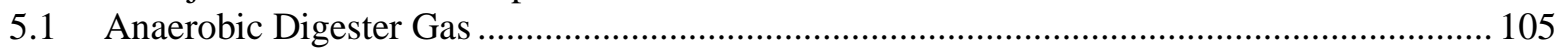

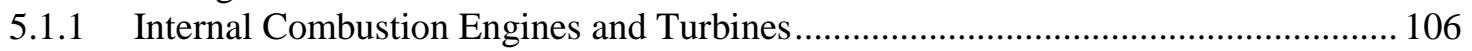

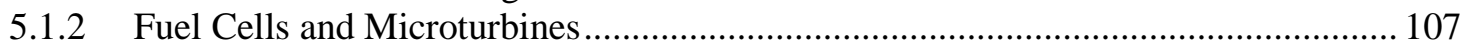

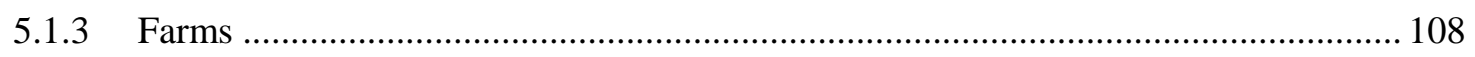

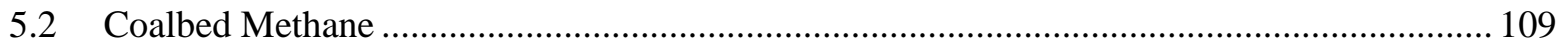

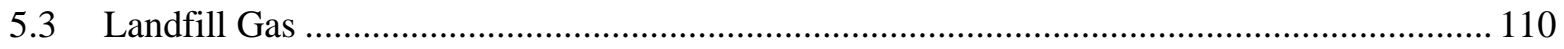

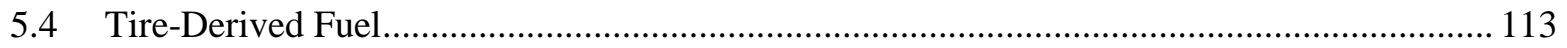

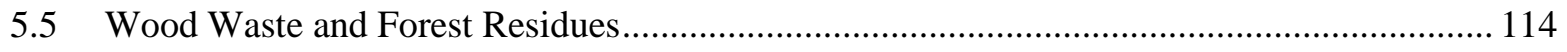

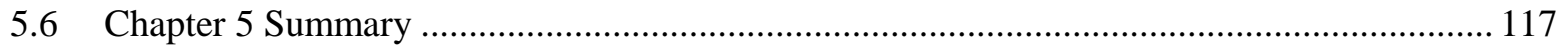

6. Analyzing Market Potential with the DISPERSE Model ........................................................ 119

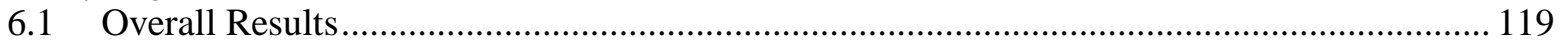

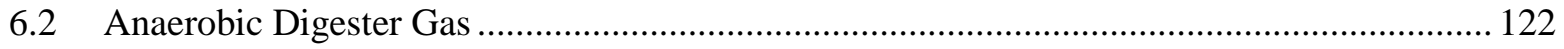




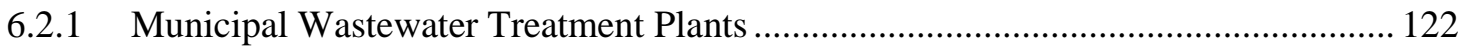

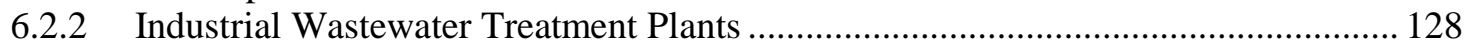

6.2.3 Anaerobic Digester Gas from Dairy Farms ....................................................... 129

6.2.4 Anaerobic Digester Gas from Swine Farms ......................................................... 132

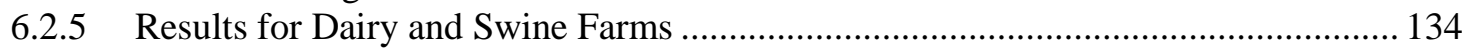

6.2.6 Anaerobic Digester Gas Results: All Sources..................................................... 136

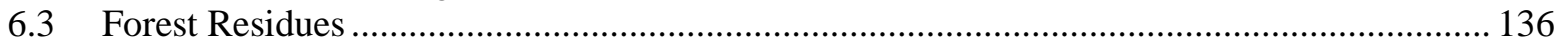

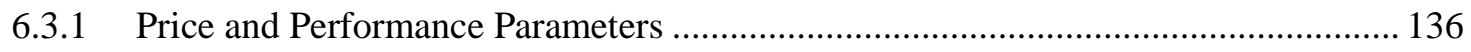

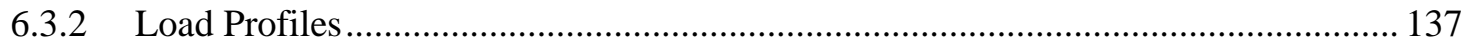

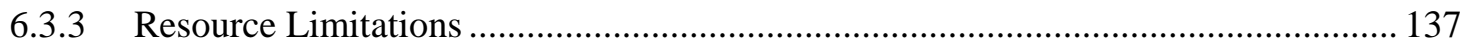

6.3.4 Results for Industrial Facilities, Not Including Power Export................................... 139

6.3.5 Special Case: Power Exporting with Pulp and Paper Mills, Wood Product

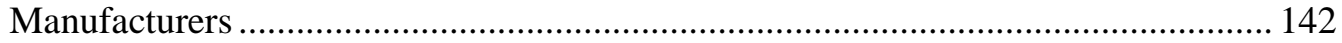

6.3.6 Sensitivity: Replacing Mill-Produced Electricity .................................................. 147

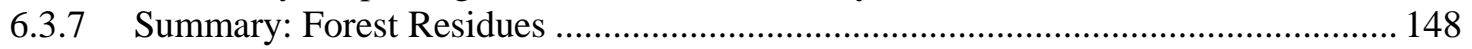

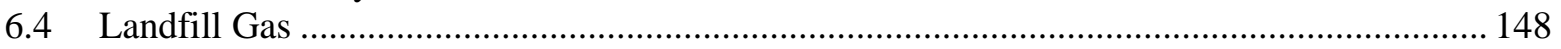

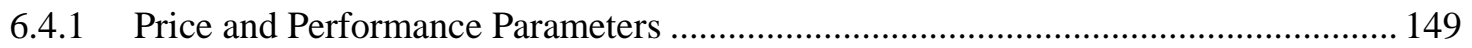

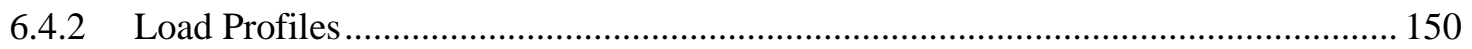

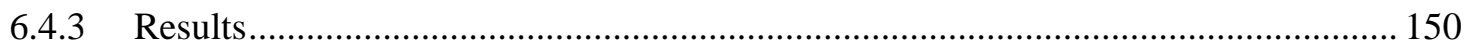

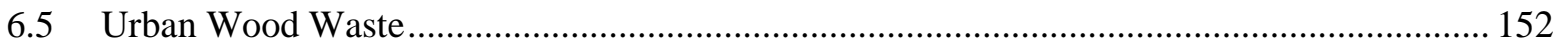

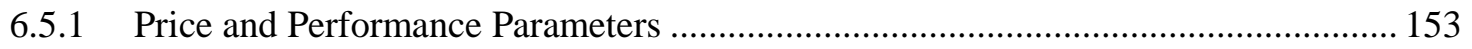

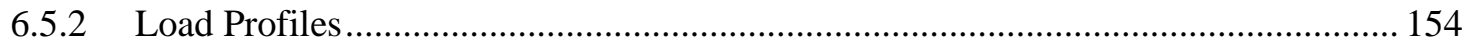

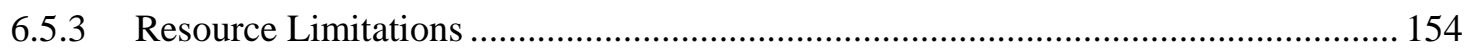

6.5.4 Results for Industrial Facilities, Not Including Power Export................................... 154

6.5.5 Special Case: Power Exporting with Pulp and Paper Mills, Wood Product

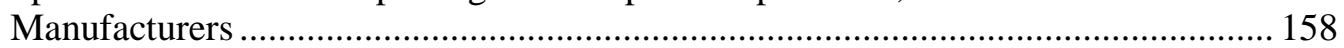

6.5.6 Sensitivity: Replacing Mill-Produced Electricity .................................................. 160

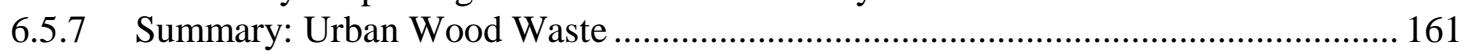

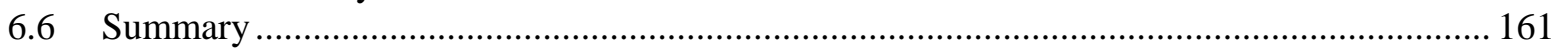

Appendix A. DISPERSE Model Methodology .............................................................................

Appendix B. Detailed Market Potential by Fuel, Facility Type and TAP Region.................................. B-3 



\section{LIST OF FIGURES}

Figure

Page

Figure 1. Estimated Economic Market Potential for Opportunity Fuels in 2013 and 2006.....................xv

Figure 2. Economic Market Potential for Opportunity Fuels, by Fuel and Facility Type ........................ xvi

Figure 3. Economic Market Potential for Opportunity Fuels, by TAP Region ......................................... xvii

Figure 4. Historical and Projected Natural Gas Prices................................................................... 1

Figure 5. Flowchart of Biomass Fuels for CHP Applications ......................................................... 6

Figure 6. The Biomass Fuels - Individual fuel types are italicized.................................................. 9

Figure 7. The Anaerobic Digestion Process: Converting Waste to Energy ............................................. 11

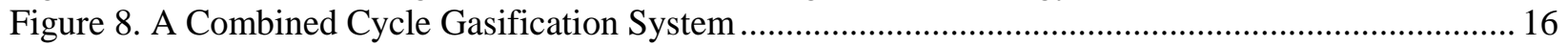

Figure 9. Crops - almost any type of crop produces residues that can be used as a fuel ........................... 20

Figure 10. Municipal Solid Waste - the source of MSW, RDF and LFG ............................................... 28

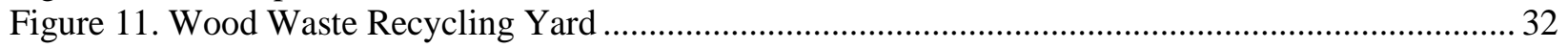

Figure 12. Fuel Gas Flare at an Oil Refinery ..................................................................................... 41

Figure 13 Coalbed Methane Collection Process - CBM can be collected before, during and after

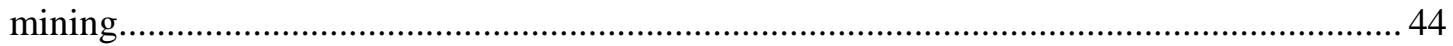

Figure 14. Tire Piles - A Potential Source of Tire-Derived Fuel …….................................................. 50

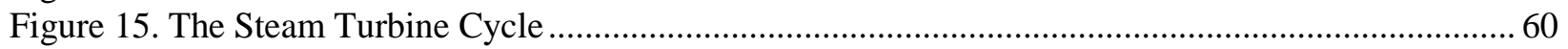

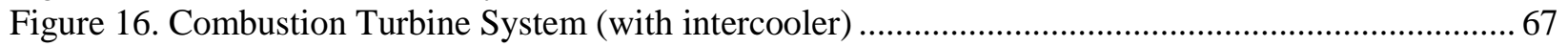

Figure 17. Schematic of an Otto (spark-ignition) Reciprocating Engine with Heat Recovery ................... 72

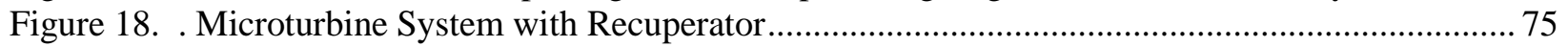

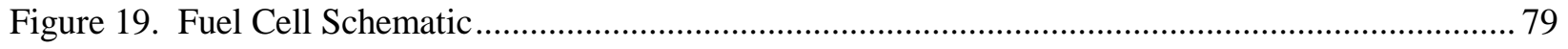

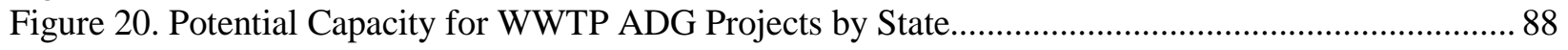

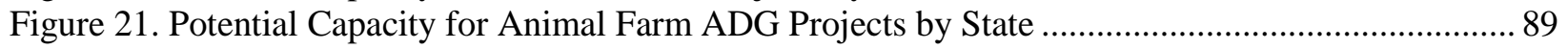

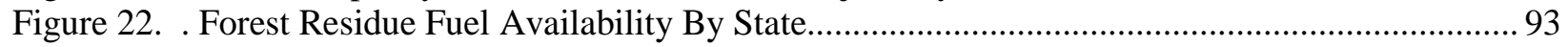

Figure 23. Estimated Potential Capacity for New LFG Projects, By State............................................. 95

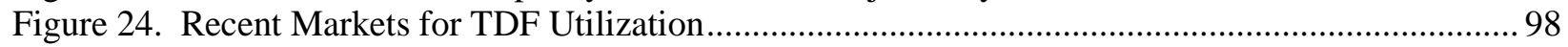

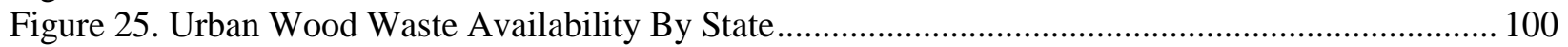

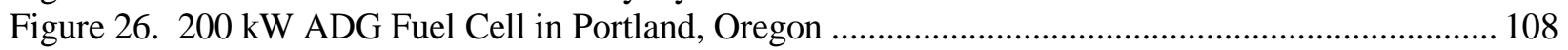

Figure 27. Landfill Gas Microturbines in Sauk County, Wisconsin.................................................... 110

Figure 28. The Sterling Energy Facility designed to burn 100 percent tire-derived fuel (Source:

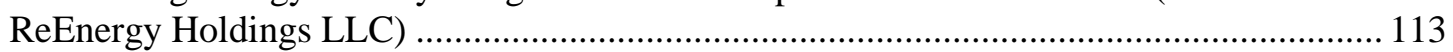

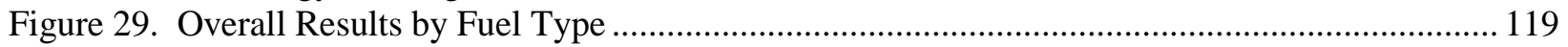

Figure 30. Top States for ADG-Fueled CHP at Municipal Wastewater Treatment Plants with

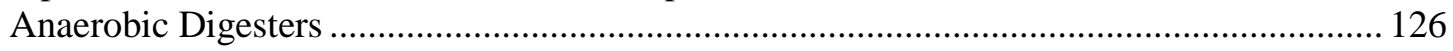

Figure 31. Payback Period Ranges for ADG CHP at Municipal WWTPs with Anaerobic Digesters (177 MW Total, Optimistic Estimate) ............................................................................... 127

Figure 32. Potential for Municipal WWTPs with Digesters by Size Range and Tech ......................... 127

Figure 33. Load Profile for a Typical Dairy Farm ............................................................................ 131

Figure 34. Load Profile for a Typical Swine Farm (950-Head Hog Operation) ...................................... 133

Figure 35. Estimated Potential for Farm-Based ADG, with and without RECs at 1 cent/kWh.............. 135

Figure 36. Economic Potential for Forest Residue CHP Applications: Top Twelve States ..................... 140

Figure 37. Economic Potential for Forest Residue CHP Applications, by Facility Type........................ 140

Figure 38. Payback Periods for Forest Residue CHP Applications (No Wood or Paper Products) .......... 141

Figure 39. Configuration of Paper Mill Boilers and Turbines Power Export Scenario, Before and

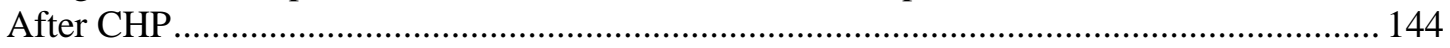

Figure 40. Economic Potential for CHP from Forest Residues with CHP Power Export Scenario .......... 147 
Figure 41. Economic Potential for LFG CHP Applications: Top Fifteen States ................................... 151

Figure 42. Payback Period Ranges for LFG CHP Projects................................................................... 151

Figure 43. Landfill Gas CHP Potential by Technology and Size Range (Optimistic Estimate).............. 152

Figure 44. Economic Potential for Urban Wood Waste CHP Applications by State ............................. 155

Figure 45. Economic Potential for Urban Wood Waste CHP Applications, by Facility Type .................. 156

Figure 46. Payback Period Ranges for Urban Wood Waste CHP Applications ...................................... 157

Figure 47. Economic Potential for CHP from Urban Wood Waste with CHP Power Export Scenario

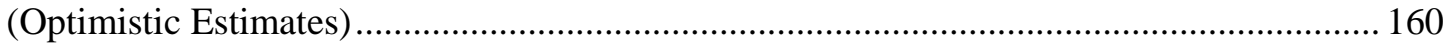

Figure 48. CHP Market Potential by Fuel Type (Optimistic Estimates) …............................................ 161

Figure 49. Estimated Potential for All Opportunity Fuels, by State ...................................................... 162

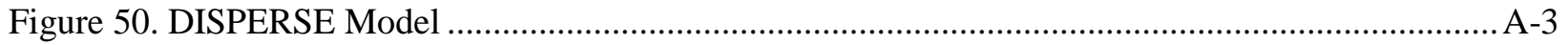

Figure 51. Installed Costs for ADG/LFG Engines, 2006 and 2013 ................................................ A-4

Figure 52. Installed Costs for ADG/LFG Turbines, 2006 and 2013....................................................

Figure 53. . Opportunity Fuel Market Potential by TAP Region.......................................................... B-3 




\section{LIST OF TABLES}

Table

Page

Table 1. Optimistic and Conservative Assumptions for Economic Analysis .............................................

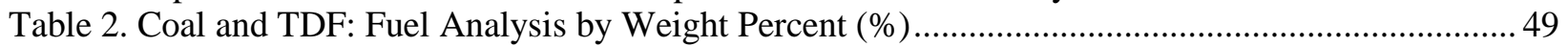

Table 3. Summary of Opportunity Fuel Attributes ................................................................................ 52

Table 4. Opportunity Fuel Performance Matrix.................................................................................... 54

Table 5. Estimated Total Installed Costs (per kW) for Boiler/Steam Turbine Systems ............................ 64

Table 6. Price and Performance Parameters for CHP Combustion Turbines (Full Pretreatment).............. 70

Table 7. Price and Performance Parameters for CHP Reciprocating Engines (Full Pretreatment) ............ 74

Table 8. Price and Performance Parameters for CHP Microturbines (Full Pretreatment) .......................... 78

Table 9. Price and Performance Parameters for CHP Fuel Cells (Full Pretreatment) ............................... 81

Table 10. Equipment and Maintenance Average Costs for CHP Equipment (Full Pretreatment)............. 83

Table 11. Wastewater Treatment Plants: Potential Projects and Capacity by State .................................. 87

Table 12. Potential MW Production from Cow and Hog Farms Large Enough for CHP Projects............. 90

Table 13. Coalbed Methane Annual Production and Future Reserves, by State ...................................... 92

Table 14. Forest Residue Availability and Technical Potential................................................................ 94

Table 15. Potential Projects and Capacity for New LFG Projects, by State ............................................ 96

Table 16. Urban Wood Waste Availability and Technical Potential .................................................... 101

Table 17. Estimated Potential Thermal and Electric Capacity for the Opportunity Fuels....................... 103

Table 18. Assumptions for Conservative and Optimistic Estimates for Each Fuel ................................ 120

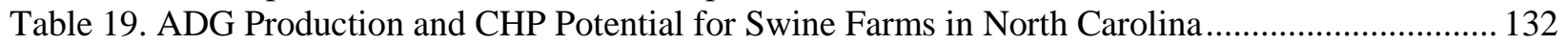

Table 20. Economic Potential for ADG from All Fuel Sources .............................................................. 136

Table 21. Forest Residues Available Annually at \$20/ton and \$40/ton................................................. 138

Table 22. Industrial Sites with Forest Residue CHP Payback Periods of Five Years or Less .................. 142

Table 23. Pulp and Paper Mills Installing New Steam Turbine CHP Systems........................................ 143

Table 24. Economic Potential for New CHP Installations at Pulp and Paper Mills using Forest

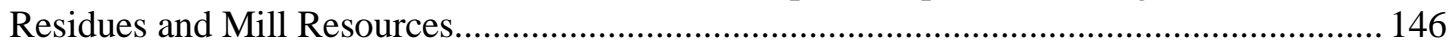

Table 25. Industrial Sites with Wood Waste CHP Payback Periods of Five Years or Less ..................... 158

Table 26. Economic Potential for New CHP Installations at Pulp and Paper Mills using Urban

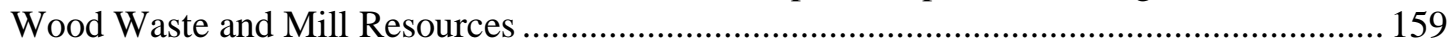

Table 27. Market Potential for ADG CHP by Facility Type and TAP Region....................................... B-4

Table 28. Market Potential for LFG CHP by Facility Type and TAP Region........................................ B-4

Table 29. Market Potential for CHP from Forest Residues, by Facility Type and TAP Region .............. B-5

Table 30. Market Potential for Urban Wood Waste CHP, by Facility Type and TAP Region................. B-5 



\section{EXECUTIVE SUMMARY}

This report updates the potential for opportunity fuel combined heat and power (CHP) applications in the United States, and provides more current estimates for the technical and economic market potential compared to those included in an earlier report. An opportunity fuel is any type of fuel that is not widely used when compared to traditional fossil fuels. Opportunity fuels primarily consist of biomass fuels, industrial waste products and fossil fuel derivatives. These fuels have the potential to be an economically viable source of power generation in various CHP applications. ${ }^{1}$ In 2006, Resource Dynamics Corporation published a report analyzing the potential for opportunity fuels to be used for distributed generation and combined heat and power. In the years that have passed, market conditions have changed and new insights have been gained. This report updates the 2006 report and seeks to capture those conditions and insights in terms of the CHP market potential. ${ }^{2}$

Out of twenty different opportunity fuels re-examined, four proved to be the most promising for CHP applications: anaerobic digester gas (ADG), landfill gas (LFG), forest residues, and urban wood waste. In most states with Renewable Portfolio Standards, all four of these fuels are considered renewable, which could increase the value of electricity generated from these resources. The available resources for these fuels amounts to $40 \mathrm{GW}$ of technical potential, but economic limitations reduce the market potential to about 3.4 GW. This is far less than the $32 \mathrm{GW}$ of economic potential found in 2006, when it was thought that biomass resources could be economically utilized in the near future with developing advanced gasifier technologies. As advanced gasifier systems have not significantly progressed towards commercialization with the expected cost reductions, they were removed from this 2013 analysis. ${ }^{3}$ Along with less favorable economic conditions toward opportunity fueled CHP applications (higher equipment costs, lower natural gas prices), this caused the estimated market potential to decline.

The CHP technologies evaluated in 2006 have advanced in their capabilities, but their costs have also increased. The range of proven CHP technologies that can be used with opportunity fuels has largely remained the same, including steam turbines, combustion turbines, reciprocating engines, microturbines and fuel cells. Estimated installed costs for all systems configured for opportunity fuels have risen, due to higher prices for materials and increased requirements and costs for fuel pretreatment equipment. In particular, siloxane removal is now seen as a requirement for most LFG and ADG installations (with the exception of farm waste), and biomass fuel preparation facilities for boiler/steam turbine systems have proven to be more expensive than previously estimated. Price and performance data for recent opportunity fuel CHP installations, including full pretreatment equipment, were incorporated into this updated analysis. Also, for solid biomass fuels, more CHP options including back-pressure and extraction steam turbines were evaluated, leading to more thermal utilization and less electric capacity for some potential sites.

\footnotetext{
${ }^{1}$ Combined heat and power applications consist of on-site distributed generation equipment configured to utilize waste heat from the prime mover to provide thermal energy for hot water, space heating, and/or process heating. CHP systems are typically more energy efficient than separate sources of heat and power.

${ }^{2}$ While the 2006 report analyzed both DG and CHP applications, all of the economic potential for opportunity fuels came from CHP applications at industrial sites (or wastewater treatment plants) where thermal energy could be thoroughly utilized. Unlike power-only DG units, CHP systems benefit from the Federal Investment Tax Credit (10 percent of the installed cost, applies to units installed by end of 2016), so they tend to provide superior economics even when thermal utilization is minimal.

${ }^{3}$ Advanced gasifiers for biomass fuels could potentially be the subject of new research and development efforts.
} 
Recently, several legislative factors have come into play that could influence the economic viability of many of these opportunity fuels, at both the federal and state level. In 2011, the U.S. Environmental Protection Agency (EPA) proposed changes to standards that would reduce emissions of air pollutants from existing and new boilers (Boiler MACT) and commercial and industrial solid waste incinerators (CISWI). The EPA recognized that boilers use a wide variety of fuels, including coal, oil, natural gas and biomass. The CISWI proposal recognizes the important relationship to the Non-Hazardous Secondary Materials (NHSM) rule, which defines solid waste for purposes of the air rules. The NHSM rule helps categorize units as either boilers or CISWI units, which have to comply with different emission limits.

EPA has also proposed revisions to its final rule which identified the types of nonhazardous secondary materials that can be burned in boilers or solid waste incinerators ${ }^{4}$. These revisions include an exemption from the CISWI rule for small power production facilities or qualifying cogeneration facilities which burn "homogeneous wastes". The EPA specifically includes tires and clean wood waste, but excludes refuse derived fuel in their definition of homogenous wastes. The final rule requires qualifying small power producers and qualifying cogeneration facilities that combust solid waste to notify the EPA that such waste is homogeneous. For information on how to obtain qualifying facility status, the Federal Energy Regulatory Commission (FERC) provides guidance on its website ${ }^{5}$. FERC Order No. 732 does not require facilities with net capacity of $1 \mathrm{MW}$ or less to make a filing with the Commission to claim QF status ${ }^{6}$.

The availability of opportunity fuels depends on a number of factors, including local resources, processing plants, and market infrastructures. For anaerobic digester gas and landfill gas, facilities are located throughout the country, with concentrations around population centers and areas with large dairies or swine operations. The availability of coalbed methane, on the other hand, is highly regional, depending on the prevalence of underground reserves and the locations of coal mines. Tire stockpiles for tire-derived fuel are located throughout the country, generally more prevalent around high-population areas. Forest residues are most readily available in the Southeast, the Northwest, and other heavily forested areas, while the availability of urban wood waste is more population-based.

Current and future opportunity fuel projects were examined to find out exactly how each fuel is being used and if there are any potential barriers, limitations, and/or drawbacks to their use. Anaerobic digester gas, landfill gas, biomass and wood waste are starting to become widely used with growing acceptance for CHP applications.

The project employed Resource Dynamics Corporation's DISPERSE model to evaluate the U. S. market for CHP applications of opportunity fuels. This model calculates the approximate cost to generate electricity and thermal energy using opportunity fueled CHP, and compares it with tariff electricity and natural gas prices throughout the country. The model, based on fuel, equipment and maintenance costs, as well as local electricity rates, chooses the best locations for potential opportunity fuel projects and calculates the overall cost to generate electricity, as well as equipment payback periods. CHP systems are sized to provide baseload electricity with no grid export and close to 100 percent utilization of thermal output. All of the model inputs (CHP price and performance, facility characteristics and locations, natural gas pricing, and utility tariff modeling) were updated for the 2013 analysis.

\footnotetext{
4 “Commercial and Industrial Solid Waste Incineration Units: Reconsideration and Final Amendments; onHazardous Secondary Materials That Are Solid Waste; Final Rule”, 78 Federal Register 26, (7 February 2013), pp.9124

${ }^{5}$ http://www.ferc.gov/industries/electric/gen-info/qual-fac/obtain.asp

${ }^{6}$ Ibid
} 


\section{MARKET POTENTIAL RESULTS}

The potential for opportunity fuels has declined since 2006 due to a number of factors including lower natural gas prices, higher fuel costs for biomass and LFG, and higher estimates for fuel pretreatment equipment. In addition, biomass gas was projected to have the most potential of all the opportunity fuels in 2006, based on widely available biomass resources, and assumptions about the near-future commercialization and pricing of advanced gasifiers. Since then, gasification technologies have not significantly advanced in commercial status, and cost reductions are no longer expected in the near term, so biomass gas was not included in this updated analysis. Finally, many sites have adopted CHP or some other use of opportunity fuels since 2006, so they have been removed from consideration. The final market analysis for opportunity fuel CHP was completed in 2013. Overall, up to $3.4 \mathrm{GW}$ of economic market potential was found among anaerobic digester gas, landfill gas and solid biomass fuels (forest residues and urban wood waste). The potential for each fuel in 2013 is compared to the 2006 potential in Figure 1.

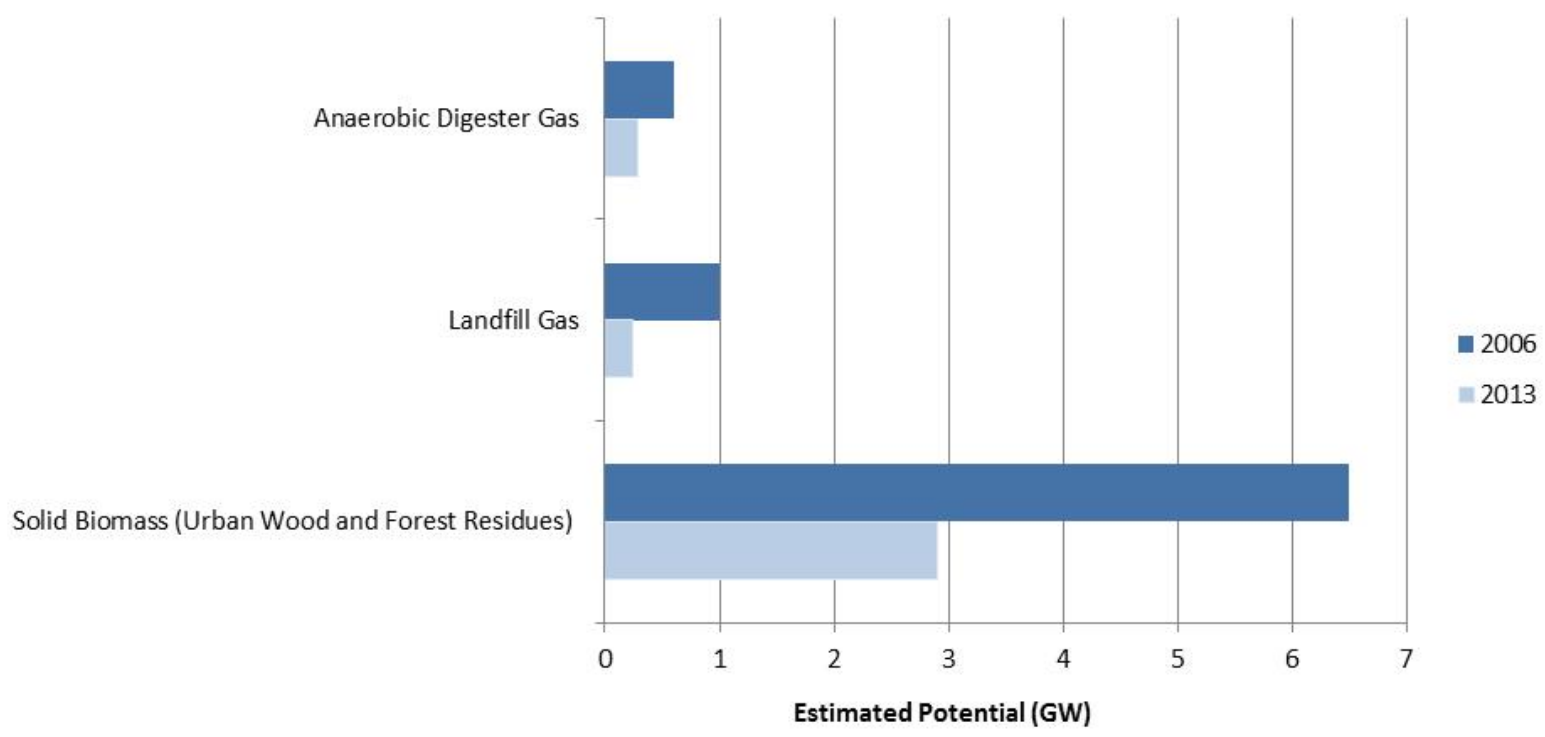

Figure 1. Estimated Economic Market Potential for Opportunity Fuels in 2013 and 2006

In the updated analysis, different assumptions were made to provide conservative and optimistic estimates of the economic market potential. The optimistic estimates were used for most market potential calculations, but the conservative estimates were included to show the effects of different sensitivities related to each fuel. In some cases, a small change in assumptions can lead to significant differences in estimated market potential. The assumptions made for both the optimistic and conservative cases are shown in Table 1 for each fuel that was included in the market analysis. 
Table 1. Optimistic and Conservative Assumptions for Economic Analysis

\begin{tabular}{|l|l|l|}
\hline Opportunity Fuel & Optimistic Assumptions & Conservative Assumptions \\
\hline $\begin{array}{l}\text { Anaerobic Digester Gas: } \\
\text { wastewater treatment plants with } \\
\text { anaerobic digesters installed }\end{array}$ & $\begin{array}{l}\text { Facilities with digesters but no } \\
\text { record of ADG utilization are } \\
\text { assumed to flare all ADG }\end{array}$ & $\begin{array}{l}\text { Facilities with digesters but no record } \\
\text { of ADG utilization are assumed to use } \\
\text { ADG for digester heating (less thermal } \\
\text { benefits) }\end{array}$ \\
\hline $\begin{array}{l}\text { Anaerobic Digester Gas: Farms } \\
\text { and WWTPs without anaerobic } \\
\text { digesters }\end{array}$ & $\begin{array}{l}\text { Digester installation costs assumed } \\
\text { to be } \$ 1,000 / \mathrm{kW}\end{array}$ & $\begin{array}{l}\text { Digester installation costs assumed to } \\
\text { be } \$ 3,000 / \mathrm{kW}\end{array}$ \\
\hline $\begin{array}{l}\text { Forest Residues (from logging } \\
\text { operations) }\end{array}$ & $\begin{array}{l}\text { Average transportation distance for } \\
\text { forest residues: } 10 \text { miles }\end{array}$ & $\begin{array}{l}\text { Average transportation distance: } 25 \\
\text { miles for pulp and paper mills, } 50 \text { miles } \\
\text { for other facilities }\end{array}$ \\
\hline Landfill Gas & $\begin{array}{l}\text { Fuel is piped } 2 \text { miles to nearby } \\
\text { industrial facility, no siloxane } \\
\text { removal required }\end{array}$ & $\begin{array}{l}\text { Fuel is piped } 5 \text { miles to nearby } \\
\text { industrial facility, and siloxane removal } \\
\text { is required }\end{array}$ \\
\hline Urban Wood Waste & $\begin{array}{l}\text { Average transportation distance for } \\
\text { urban wood waste: } 10 \text { miles }\end{array}$ & $\begin{array}{l}\text { Average transportation distance for } \\
\text { urban wood waste: 25 miles }\end{array}$ \\
\hline
\end{tabular}

The 2013 economic potential is broken down more specifically by fuel source in Figure 2, using the optimistic assumptions.

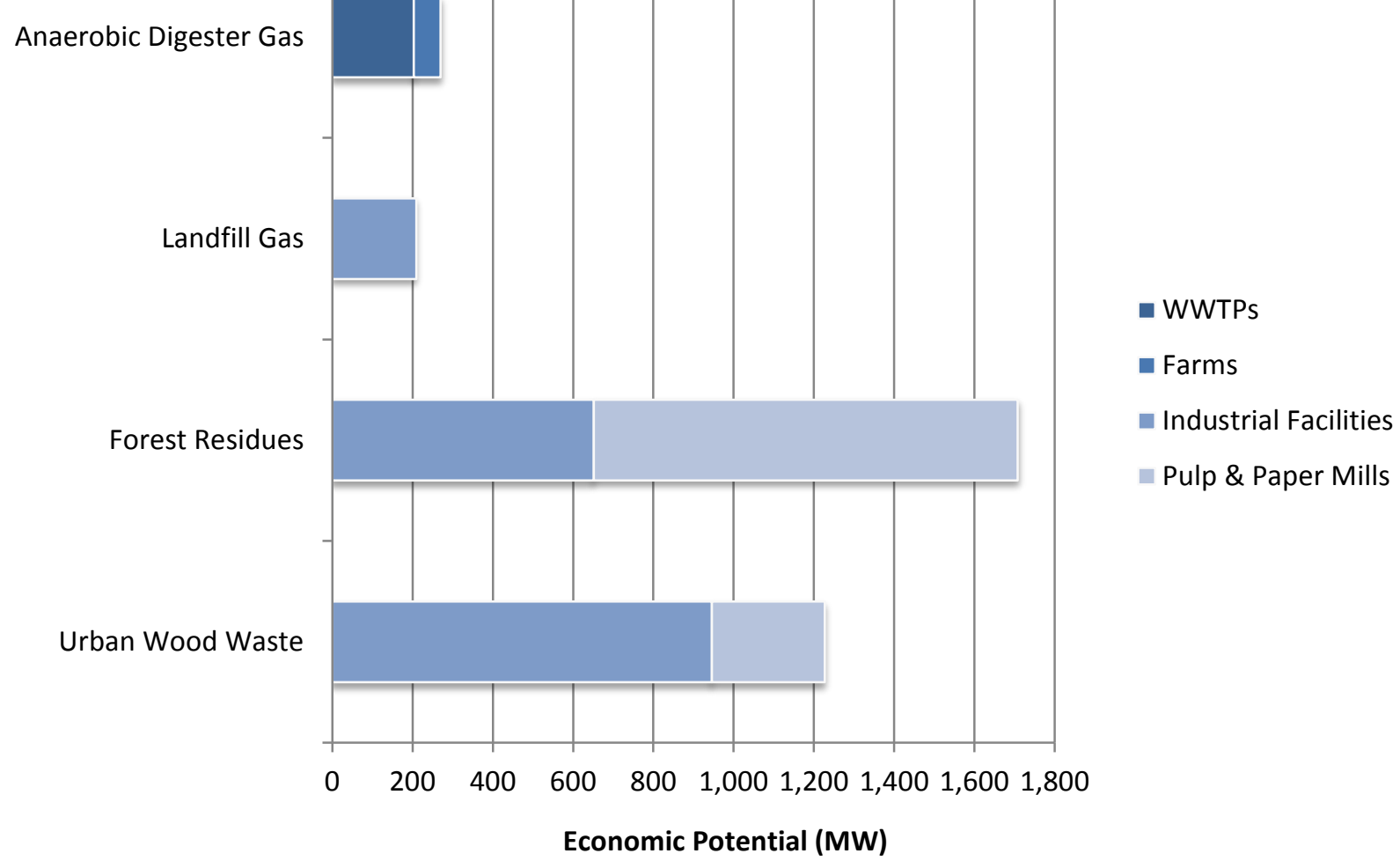

Figure 2. Economic Market Potential for Opportunity Fuels, by Fuel and Facility Type 
The largest opportunities lie with forest residues and urban wood waste, with nearly 3 GW of combined potential. For forest residues, most of the potential comes from power-exporting CHP systems at pulp and paper mills, treated as a special case in the economic analysis. However, the potential quickly drops off as average fuel transportation distances increase. Urban wood waste is usually a less-expensive source of biomass fuels, and resources are concentrated around population centers, so transportation costs are not as much of an issue. All of the potential for urban wood waste and forest residues comes from boiler/steam turbine applications $1 \mathrm{MW}$ or larger in size.

For ADG and LFG, the majority of potential comes from reciprocating engine applications in the $500 \mathrm{~kW}$ to $5 \mathrm{MW}$ size range. A few large sites are able to take advantage of applications for combustion turbines 5-20 MW in size, and there are a number of sites with small $(<500 \mathrm{~kW})$ engine and microturbine applications at facilities that cannot handle larger systems. Microturbines and fuel cells were generally found to be more expensive on a per-kW basis compared to reciprocating engines of similar sizes, although it should be noted that these system are being installed in some cases, as sites are either taking advantage of unique state incentives or prefer certain aspects of these technologies.

The results were also broken down by the DOE CHP Technical Assistance Partnership (TAP) region in Figure 3.

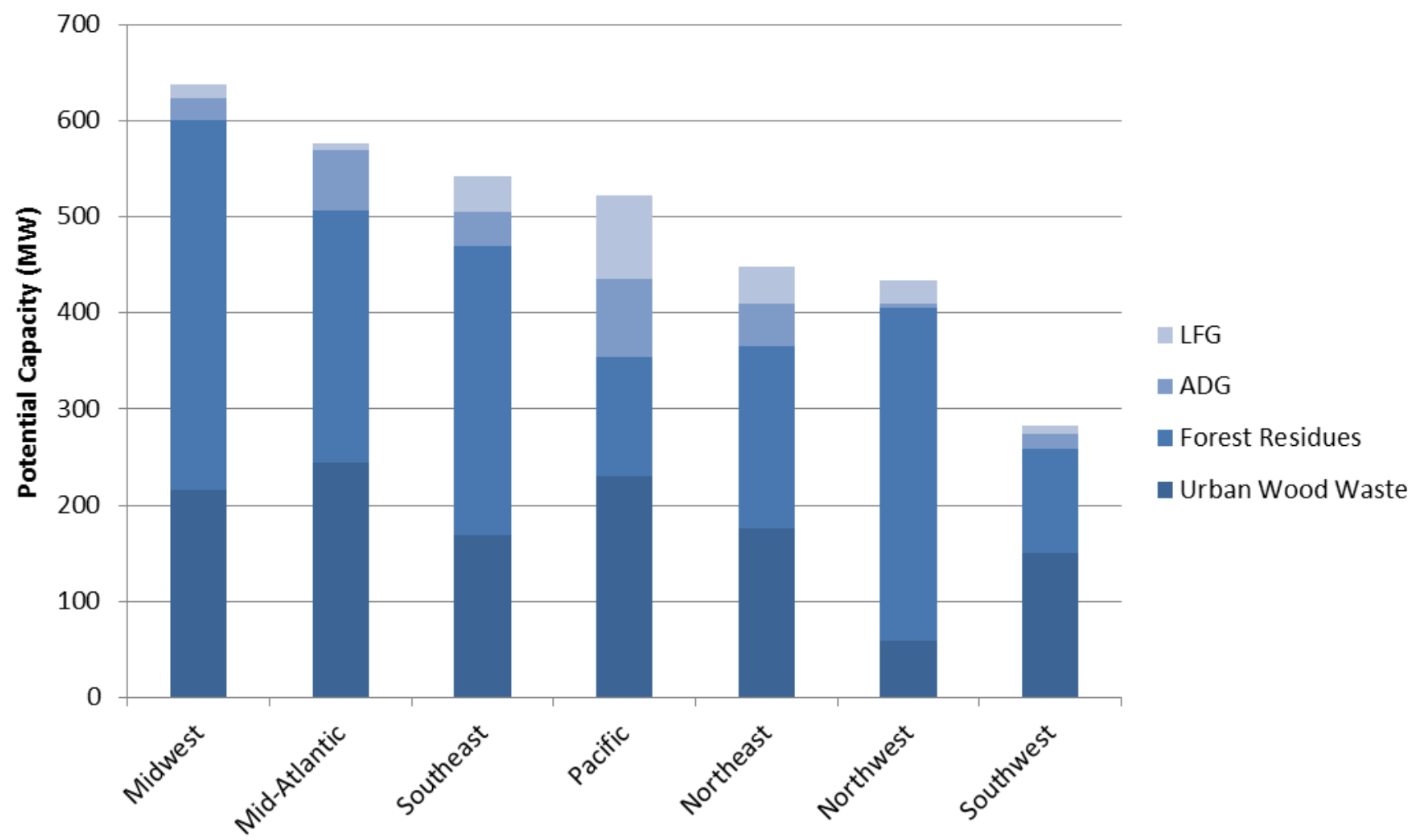

Figure 3. Economic Market Potential for Opportunity Fuels, by TAP Region

The Midwest and Mid-Atlantic regions combine for over 1.2 GW of potential, largely thanks to powerexporting CHP systems at pulp and paper mills using forest residues or urban wood waste as fuel sources. The Pacific region, strengthened by California's abundant resources and high electricity prices, also has 
very strong economic potential for CHP with a total of over $500 \mathrm{MW}$. The Southeast and Northwest regions show strong potential, especially at pulp and paper mills, but project economics in these regions strongly depend on short transportation distances for biomass resources. The heavily-populated Northeast region, with high electricity and natural gas prices, produces more stable economics, but opportunities at pulp and paper mills are not as plentiful.

Of the 3.4 GW of market potential found in opportunity fuels, over $2.9 \mathrm{GW}$ comes from solid biomass fuels, while about $500 \mathrm{MW}$ comes from landfill gas and anaerobic digester gas. The revised economic potential is substantially lower than what was estimated in 2006, but there are still many facilities that can take advantage of ADG, LFG and biomass fuels as relatively low-cost fuel sources for CHP. While some near-term commercial progress was assumed for gasification systems in 2006, that has not yet materialized, and the potential estimated here is based on current technologies, prices, and markets. These estimates are believed to realistically reflect the potential for opportunity fuels in the near future. The lower price of natural gas, increased transportation costs, and other cost-related factors have weakened the value proposition of opportunity fuels over the past few years, but there are still numerous sites that can economically benefit from their utilization.

\section{RECOMMENDATIONS}

Based on the findings, the primary areas of emphasis for growth in CHP should be:

1) ADG CHP projects at large municipal wastewater treatment plants in Mid-Atlantic and Midwest locations with attractive economics, as well as California

2) LFG CHP projects at industrial facilities located near large California landfills that are not currently engaged in energy projects

3) Urban wood waste CHP projects at industrial facilities near population centers in California, Florida, Massachusetts, New Jersey, New York and Texas

4) Forest residue CHP projects at industrial facilities in Pennsylvania, New York, and other locations with nearby access to forest residues from logging operations

5) Large pulp and paper mills with abundant nearby biomass resources (forest residues and/or urban wood waste) and a local utility that may be willing to help finance a power-exporting CHP system

To increase interest and awareness, project developers should be made aware of the renewable benefits of opportunity-fueled CHP installations, and utilize any local, state, or federal assistance programs for renewable CHP projects. The analysis in this report included a 10 percent federal investment tax credit for CHP systems, and the economics for many projects would improve with additional financial assistance. If a more detailed analysis were to include state and utility-based incentive programs for renewable fuels and/or CHP, it is likely that more economic market potential would be found. 




\section{INTRODUCTION}

One of the most prevalent forms of distributed energy is combined heat and power (CHP), where distributed resources are used to generate power as well as provide useful thermal output. While CHP units can be sited independently of the grid, most are interconnected so that they can receive supplementary and backup power from their local utility. To date, the majority of CHP units have been fueled by natural gas, whose price has been volatile over the past decade (see Figure 4).

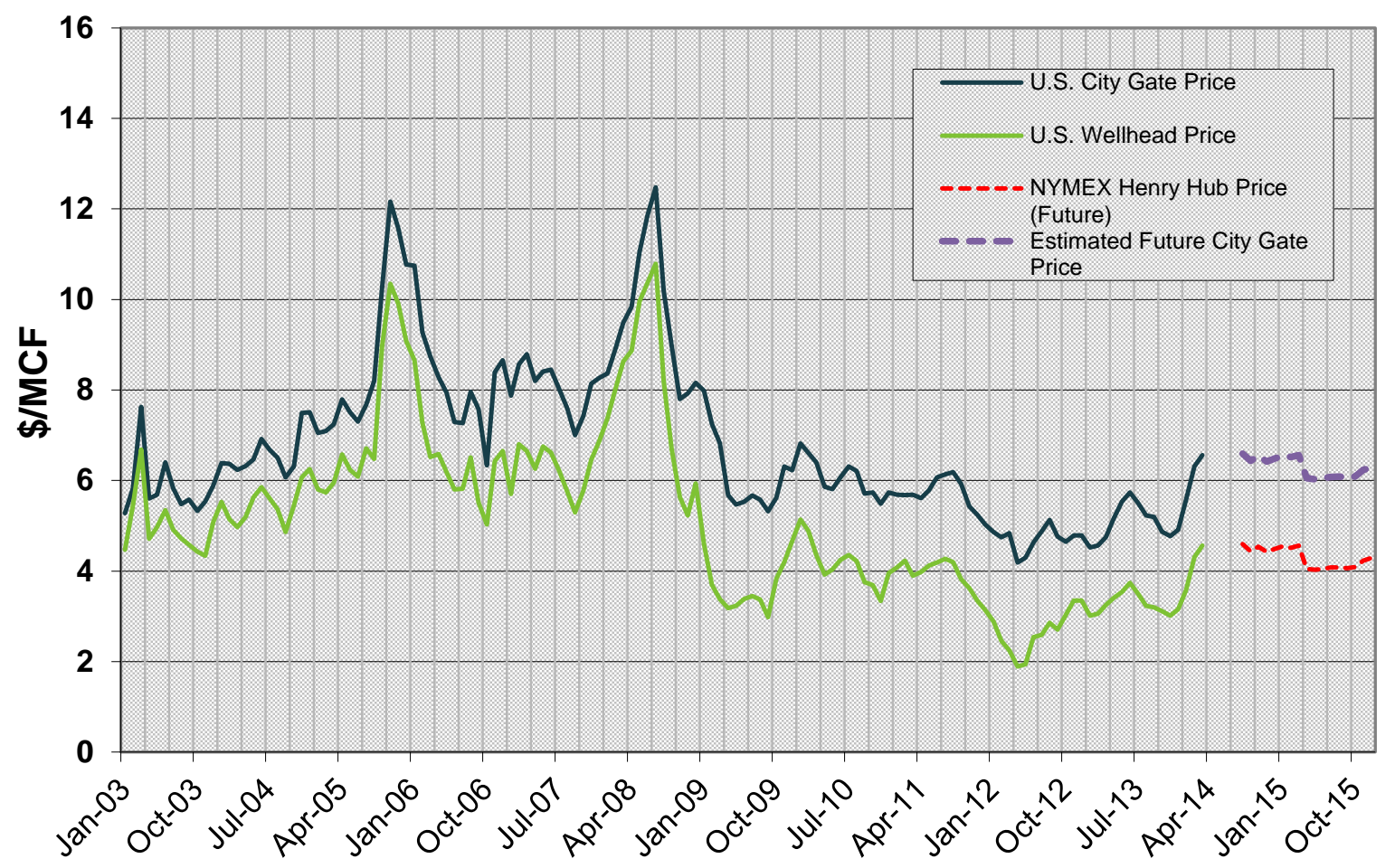

Figure 4. Historical and Projected Natural Gas Prices

Source: EIA and NYMEX, June 2014

Opportunity fuels, defined as any type of fuel that is not widely used but has the potential to be an economically viable source of power generation, can often be obtained for significantly less than natural gas and other fuels for CHP applications. Opportunity fuels are typically unconventional, and usually derived from some sort of waste or byproduct. Most are inferior to conventional fossil fuels in some way, and they often require significant fuel treatment. However, the supply of fossil fuels is limited and their prices are volatile. Some opportunity fuels could potentially provide an inexpensive and reliable alternative. With volatile fossil fuel prices and the need for more environment-friendly energy sources, opportunity fuels are likely to gain in market share over the coming years. Not every opportunity fuel is well suited for CHP applications, but many are capable of providing power and heat to a variety of commercial and industrial applications. This report evaluates some of the more promising opportunity fuels that are well suited for CHP and examines their potential market impacts. 
This document is an update of the 2006 report for the Department of Energy's Energy Efficiency and Renewable Energy program and Oak Ridge National Laboratory titled Combined Heat and Power Market Potential for Opportunity Fuels. ${ }^{7}$ There have been several developments in opportunity fuels in the six years since the original report was published, and this report has been developed to update the previous information and provide new estimates for market potential.

The most significant change in this update resulted from the elimination of biomass gas from economic consideration. In the 2006 report, biomass gas (generated with advanced biomass gasifiers) was speculated to have over $20 \mathrm{GW}$ of economic potential in the near future. Since then there have been a lack of developments that were anticipated with advanced gasification technologies and estimated installation and maintenance costs not fallen as expected. Estimated installed costs for gensets and accompanying technologies have also increased since the 2006 report, and electricity and natural gas costs are generally less favorable, so conditions were not as promising for opportunity fuels as they were in 2006. Other important alterations of the original document are noted as they occur in this updated report.

\subsection{PROJECT OBJECTIVES}

The objectives of this project are to:

- Identify potential opportunity fuels

- Research their availability and capability to be used in CHP applications,

- Examine CHP technologies that can use these opportunity fuels, and

- Perform a market assessment to determine the potential market for opportunity fueled CHP applications.

\subsection{APPROACH}

The project employed a three-task approach to evaluate and analyze the opportunity fuels:

\subsubsection{Task 1 - Collect Opportunity Fuels Information}

This task collected and summarized key opportunity fuel information. Existing relevant studies were catalogued and reviewed for valuable information. Distributed energy equipment manufacturers and other stakeholders were contacted and interviewed for their experience with the use of opportunity fuels. Information on the quality characteristics of the available opportunity fuel sources, their potential suitability as a CHP fuel for sites that are located on the grid, and their potential environmental implications was examined. Rough supply availability and cost estimates for each reasonably suitable and available opportunity fuel were also developed. In concluding this task, the eight opportunity fuels most suitable for CHP applications were chosen for further analysis of economic market potential.

\footnotetext{
${ }^{7}$ Combined Heat and Power Market Potential for Opportunity Fuels. Prepared for: U.S. Department of Energy, Energy Efficiency and Renewable Energy, and Oak Ridge National Laboratory. Prepared by: Resource Dynamics Corporation. 2006.
} 


\subsubsection{Task 2 - Evaluate CHP Technology Options}

This task examined the CHP technologies that have successfully used opportunity fuels. The technologies considered include reciprocating engines, microturbines, combustion turbines, steam turbines (and associated boiler systems), fuel cells, and Stirling engines. Collectively, these technologies are referred to as prime movers. Other technologies that are required when using opportunity fuels, such as gasifiers, were also researched. From these, a set of cost, performance, efficiency and emissions data was developed for each prime mover type consuming a particular opportunity fuel.

For each CHP/DG technology, the following information was collected and analyzed:

- History and Status. The history of the technology is reviewed, and its current status in the marketplace is detailed.

- Operation. The operational methodology of the technology is described, along with a schematic diagram.

- Emissions Controls. Emissions and emissions control technologies are reviewed.

- Efficiency. Electric and overall efficiency are addressed.

- Equipment Costs and Modifications for each Opportunity Fuel. For each DG equipment/opportunity fuel combination, estimates of equipment capital costs, installation costs, and modification costs (new and retrofit) are presented.

- Maintenance Costs and Issues with Opportunity Fuels. Maintenance costs are discussed, maintenance issues for each opportunity fuel are identified, and associated costs are estimated.

- Applications. Common applications (e.g., baseload power, CHP, peak shaving) are listed.

\subsubsection{Task 3 - Analyze Potential Market Impacts and Develop Recommendations}

In this task, the economic market potential for CHP technologies was modeled by examining each combination of technology and opportunity fuel to determine where economically feasible applications have significant potential. The availability and potential for each opportunity fuel was analyzed to determine the 4 most promising opportunity fuels, and to determine inputs for The Distributed Power Economic Rationale Selection (DISPERSE) model, a proven tool that accurately projects the potential for different distributed energy and CHP technologies, by market sector, application type, power size range, and state. This model takes into account the price and performance of distributed energy technologies, utility-specific grid and natural gas prices, facility thermal and electric load profiles, and emissions regulations/permitting levels.

The economic analysis approach uses a four-step process to estimate the potential market for an on-site power generation technology (see Appendix B for more details). After the market potential for each opportunity fuel was estimated, the results were analyzed, interpreted and presented, and conclusions were drawn.

\subsection{UPDATING THE REPORT}

These tasks were performed over several years for the original report, Combined Heat and Power Market Potential for Opportunity Fuels, which was compiled in 2004 and 2005, and published in 2006. For the updated report, compiled from 2012-2014 and published in 2015, these three tasks were revisited, 
researching current information on the fuels and markets and updating the text with any recent developments. The utility tariffs and equipment pricing were also updated for the market analysis, reflecting recent opportunity fuel installations.

\subsection{REPORT ORGANIZATION}

Part I of this report is an introduction to the various opportunity fuels and CHP technology options. The current status, technology, economics, market conditions and environmental issues associated with each fuel are discussed. Availability, cost, and installed capacity data are also included where available. After each fuel has been analyzed, the opportunity fuels with the most CHP potential are chosen for further evaluation. Next, the prime mover technologies required to utilize these fuels are discussed, and cost estimates for both equipment and maintenance are made. Following that, the availability and technical market potential of each fuel is analyzed in detail, and the current status and future outlook for each fuel is discussed. From this, the top opportunity fuels for DER/CHP applications are selected for the economic analysis.

Next, in Part II, the market potential analysis is presented. This section focuses on the most promising fuels, and provides the potential market impacts, key segments, leading technology options, unit sizes, and other key information. 


\section{THE OPPORTUNITY FUELS}

An opportunity fuel is defined as any type of fuel that is not widely used, but could have the potential to be an economically viable source of power generation. To assemble a list of opportunity fuels to evaluate, an extensive research of literature and technical studies was conducted. Biomass fuels, landfill gas, anaerobic digester gas, coalbed methane, petroleum coke and tire-derived fuel have been the subjects of various research studies, so these fuels topped the list of potential candidates. For the 2015 revision of this report, refinery fuel gas was added to the opportunity fuels, Orimulsion was removed, forest residues were separated from "wood and wood waste" fuels, and information for all of the different fuels was reviewed and updated. As a result of these efforts, nineteen opportunity fuels were identified as potential candidates for combined heat and power (CHP) applications:

- Anaerobic Digester Gas, from wastewater treatment plants and farms

- Biomass Gas, produced from gasifiers using biomass feedstocks

- Black Liquor, produced at pulp and paper mills

- Blast Furnace Gas, from steel-making blast furnaces

- Coalbed Methane, vented from underground coal mines

- Coke Oven Gas, from integrated steel mills and merchant coke plants

- Crop Residues, collected from agricultural land

- Food Processing Waste, from food processing facilities

- Forest Residues, collected from lumber operations and forest thinning

- Industrial VOCs, from chemical plants and other manufacturing facilities

- Landfill Gas, a methane gas created from decomposition in landfills

- Municipal Solid Waste and Refuse-Derived Fuel, using solid waste as fuel

- Petroleum Coke, a by-product of petroleum refineries

- Refinery Fuel Gas (Still Gas), waste gas from petroleum refineries

- Sludge Waste, sludge from wastewater treatment plants or pulp \& paper mills

- Textile Waste, from textile mills

- Tire-Derived Fuel, processed from scrap tires

- Wellhead Gas, collected at oil wells

- Wood Waste, from construction/demolition debris, tree/shrub clippings, or lumber mills

Most of the opportunity fuels can be divided into two categories: biomass fuels and industrial process waste or byproducts. Biomass fuels can take on many different forms, but all of them are derived from the carbon-based materials present in living organisms. There are seven main types of solid biomass fuels: crop residues, farm waste, food processing waste, forest residues, municipal solid waste, sludge waste, and wood waste. All of these fuels can be processed and combusted in a boiler/steam turbine configuration, some more easily than others. Most of these potential fuels are found in low-moisture form, with the exception of farm waste, sludge waste, and some types of food processing waste, which are high-moisture fuels ideal for anaerobic digestion (producing a gaseous fuel). 
Black liquor, a byproduct of the pulping process, is also a high-moisture biomass fuel, but it is usually directly burned in boilers or gasified due to its high heat content. Most pulp mills use their black liquor on-site, but it is sometimes made available to other sites.

From these solid biomass fuels, several liquid and gaseous fuels can be formed, such as ethanol, biomass gas, landfill gas, and anaerobic digester gas. Figure 5 illustrates the relationship between the different biomass fuels, and how they can be used with CHP technologies.

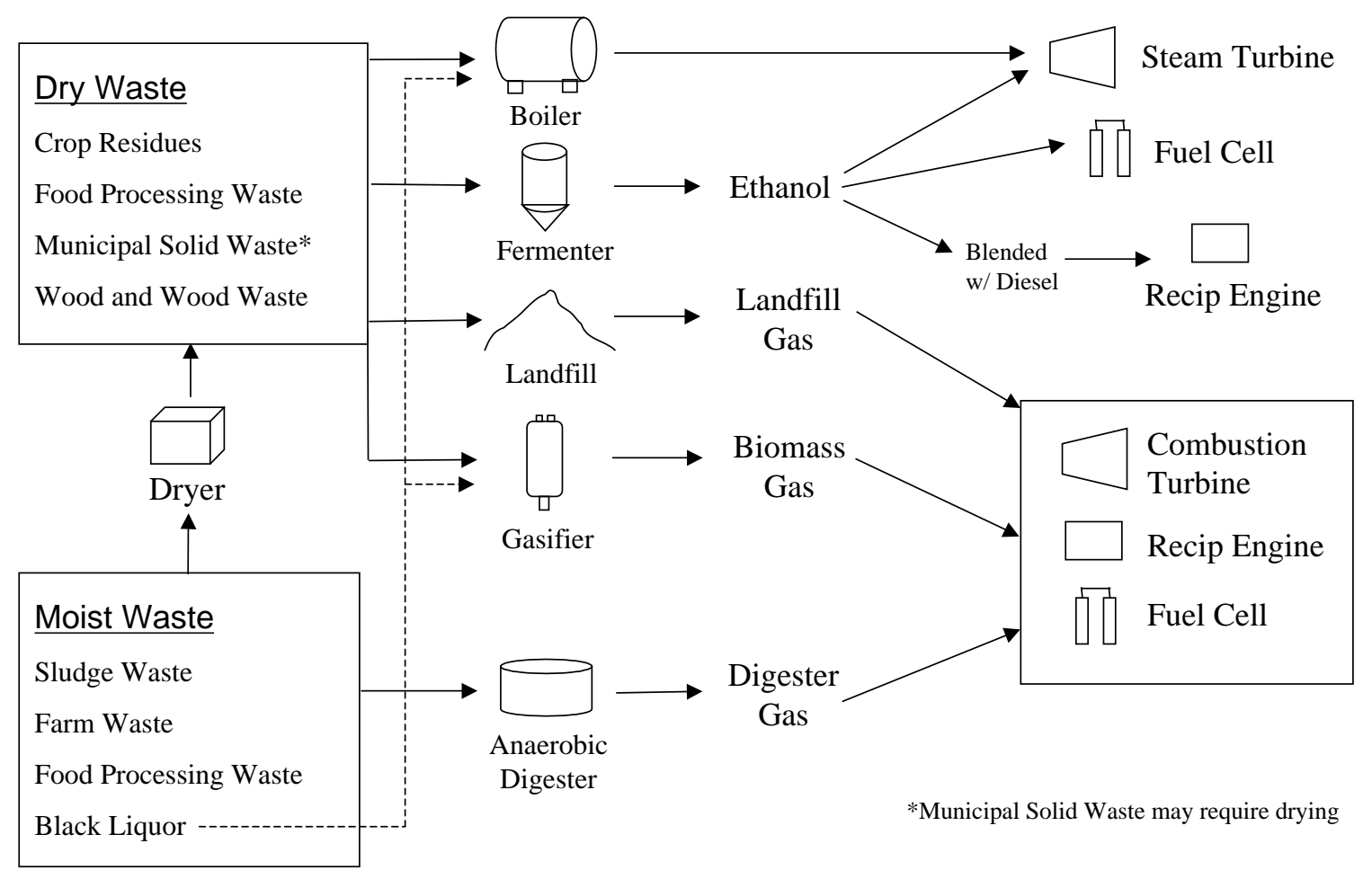

Figure 5. Flowchart of Biomass Fuels for CHP Applications

The second largest group of opportunity fuels consists of waste and byproducts from industrial processes. Iron and steel mills, petroleum refineries, textile mills, and various industrial facilities produce waste and byproduct solids and gases that can be used as fuels. There are six different opportunity fuels that can be obtained from industrial processes, and they are reviewed in the first chapter:

- Blast Furnace Gas

- Coal Coke

- Coke Oven Gas

- Industrial VOCs

- Petroleum Coke

- Refinery Fuel Gas

- Textile Waste 
The third category of opportunity fuels is fossil fuel derivatives. These fuels are byproducts derived from traditional fossil fuels, such as coal and natural gas. While some of the industrial process fuels like petroleum coke may fall in this category as well, only coalbed methane and wellhead gas are derived directly from fossil fuel mining and drilling operations. Both fuels have high heating values and are most commonly flared on-site when CHP is not used.

Finally, there is one opportunity fuel that does not fall into the other categories. Tire-derived fuel (TDF), a fuel processed from scrap tires, is already being produced and sold, but for a very limited market. TDF has a high energy content and could potentially replace coal as a boiler fuel for steam turbine applications.

Overall, there are 19 different opportunity fuels to evaluate, and they will be examined in the following order:

\section{Biomass Fuels}

- Anaerobic Digester Gas

- Biomass Gas

- Black Liquor

- Crop Residues

- Food Processing Waste

- Forest Residues

- Landfill Gas

- Municipal Solid Waste (and Refuse Derived Fuel)

- Sludge Waste

- Wood Waste

\section{Industrial Process Waste and Byproducts}

- Blast Furnace Gas

- Coke Oven Gas

- Industrial VOCs

- Petroleum Coke

- Refinery Fuel Gas

- Textile Waste

\section{Fossil Fuel Derivatives}

- Coalbed Methane

- Wellhead Gas

\section{Processed Opportunity Fuels}

- $\quad$ Tire Derived Fuel

Recently, several legislative factors have come into play that could influence the economic viability of many of these opportunity fuels, at both the federal and state level. In 2011, the U.S. Environmental Protection Agency (EPA) proposed changes to standards that would reduce emissions of air pollutants from existing and new boilers (Boiler MACT) and commercial and industrial solid waste incinerators (CISWI). The EPA recognized that boilers use a wide variety of fuels, including coal, oil, natural gas and 
biomass. The CISWI proposal recognizes the important relationship to the Non-Hazardous Secondary Materials (NHSM) rule, which defines solid waste for purposes of the air rules. The NHSM rule helps categorize units as either boilers or CISWI units, which have to comply with different emission limits. EPA has also proposed revisions to its final rule which identified the types of nonhazardous secondary materials that can be burned in boilers or solid waste incinerators ${ }^{8}$. These revisions include an exemption from the CISWI rule for small power production facilities or qualifying cogeneration facilities which burn "homogeneous wastes". The EPA specifically includes tires but excludes refuse derived fuel in their definition of homogenous wastes. The final rule requires qualifying small power producers and qualifying cogeneration facilities (QFs) that combust solid waste to notify the EPA that such waste is homogeneous. For information on how to obtain qualifying facility status, the Federal Energy Regulatory Commission (FERC) provides guidance on its website ${ }^{9}$. FERC Order No. 732 does not require facilities with net capacity of $1 \mathrm{MW}$ or less to make a filing with the Commission to claim QF status ${ }^{10}$.

Although the Boiler MACT and CISWI rules have the potential to limit the viability of certain opportunity fuels, there are other legislative measures, primarily at the state level, that can provide economic incentives. Renewable portfolio standards (RPS) of some sort have been implemented in over half of the states in the country, although many of these standards focus on solar and wind power. These standards typically call for utilities to incorporate a certain percentage of renewable fuels into their energy portfolios, with increasing percentages in future years, until an ultimate goal is reached. Utilities that do not comply with the standards are penalized at the end of each year.

An increasing number of states are incorporating market-based RPS programs that issue renewable energy credits (RECs) for each megawatt-hour of energy produced using qualifying fuels or technologies. In most cases, renewable fuels and technologies are divided into tiers, with solar and wind in the top tier, and biomass and other renewable fuels in lower tiers. State goals are often more aggressive for top tier resources, and the market value of solar and wind RECs can be much higher than other lower-tier fuels. Currently, the market value of most RECs for biomass and other lower-tier fuels is fairly insignificant, offering only a small fraction of a penny for each kilowatt hour produced. While this could change in the future, this analysis will not consider the value of RECs when evaluating project economics.

Economic incentives for opportunity fuels can also be provided through grants from utilities, states, and even the federal government. Grants for renewable fuel projects and combined heat and power installations can often provide the financial assistance needed for projects to become economically viable. While most utilities and states do not offer grants for biomass or other opportunity fuels (solar and wind projects again take precedence), some do offer grants that would be applicable to certain renewable opportunity fuels. But these grants are offered on a limited basis, with funding capped at a certain annual limit, so most applications for state or utility-based grants cannot be fulfilled. However, the federal government does provide an investment tax credit for up to 10 percent of the project cost for new CHP installations, regardless of the fuel used. Performance-based incentives are also offered for certain renewable energy projects in the form of a production tax credit, but these two credits cannot be applied to the same project, and an economic analysis showed that the 10 percent investment tax credit was the more favorable option for most renewable CHP systems.

For this analysis, the future Boiler MACT and CISWI rules, as well as potential renewable portfolio standards and grants, will only be considered anecdotally. The only exception is the federal investment tax credit that reimburses 10 percent of the total cost of CHP projects - this grant will be applied to all

\footnotetext{
8 “Commercial and Industrial Solid Waste Incineration Units: Reconsideration and Final Amendments; on-Hazardous Secondary Materials That Are Solid Waste; Final Rule”, 78 Federal Register 26, (7 February 2013), pp.9124

${ }^{9}$ http://www.ferc.gov/industries/electric/gen-info/qual-fac/obtain.asp

${ }^{10}$ Ibid
} 
potential installations in the economic analysis. The final form of future legislation for Boiler MACT and CISWI is not certain, and not all potential projects would have access to state or utility-based grants with limits on total funding. The economic implications of renewable portfolio standards are currently minimal for the opportunity fuels considered in this report, as the majority of incentives are geared towards solar and wind projects.

In this chapter, the current status, technologies, economics, market conditions and environmental issues associated with each fuel are discussed. Availability, cost, and installed capacity data is provided when available. After all of these fuels have been analyzed, the opportunity fuels with the strongest potential for CHP projects are chosen for further evaluation.

\subsection{BIOMASS FUELS}

Biomass fuels are derived from organic biological material. They generally consist of residues, waste, and gases produced by living organisms. For this reason, biomass is often considered a renewable source of energy. The various paths that the solid biomass fuel sources can take are depicted Figure 6.

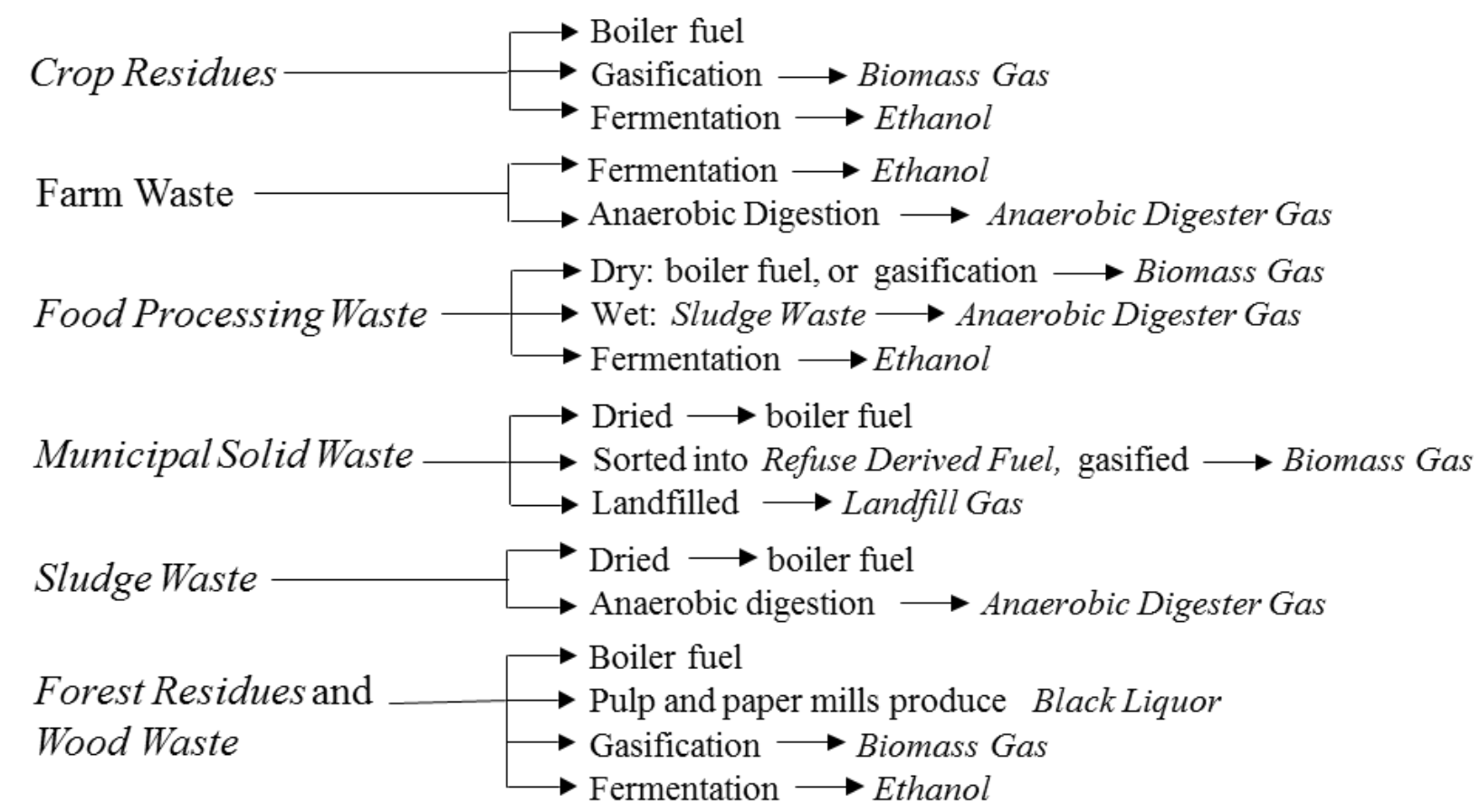

Figure 6. The Biomass Fuels - Individual fuel types are italicized.

In the United States, biomass fuels currently account for about $10 \mathrm{GW}$ of electric capacity - second only to hydropower for renewable fuels. ${ }^{11}$ Still, biomass resources are largely underutilized. Recent studies indicate that large quantities of currently unused biomass resources could compete with coal and other

\footnotetext{
${ }^{11}$ Haq, Zia, Biomass for Electricity Generation, United States Energy Information Administration, Electricity Analysis Reports, May 2006, http://www.eia.gov/oiaf/analysispaper/biomass/
} 
solid fuels in certain markets. ${ }^{12}$ The current installed capacity of biomass could significantly increase if these resources were utilized for fuel.

For biomass power producers, there are a number of government-funded incentives that could provide financial assistance. Commercial and industrial facilities utilizing biomass fuels can apply for the federal renewable electricity production tax credit, which provides 2.3 cents/kWh for closed-loop biomass resources (i.e. dedicated energy crops), and 1.1 cents/kWh for other eligible technologies, including landfill gas, digester gas, MSW, and other biomass fuels, over a ten year period. ${ }^{13}$ However, facilities would have had to begin construction prior to 2014 to claim the credit ${ }^{14}$.

Alternatively, new CHP installations qualify for the 10 percent federal investment tax credit, which effectively reduces installation costs by 10 percent. ${ }^{15}$ Many state governments also offer loans, grants, credits, or tax exemptions of some sort for facilities utilizing biomass power. See the U.S. Department of Energy's Database of State Incentives for Renewables and Efficiency at www.dsireusa.org for an up-todate list of policies and incentives for each state. Nearly all biomass power production projects can qualify under the Public Utility Regulatory Act (PURPA) as qualifying facilities and small power producers. The act requires utilities to purchase any excess power generation, usually at their avoided cost, from facilities using renewable fuels or combined heat and power. Subsequent legislation, in 2005, limited utilities located within regional transmission organizations or in Texas to being required to offer this option to qualifying facilities under $20 \mathrm{MW}$.

The continued need for on-site industrial power, waste reduction, more environmentally favorable energy use, national energy security, and consumer demand for renewable energy can help fuel the biomass industry's growth. Cofiring solid biofuels with coal often requires no equipment modifications, and can reduce boiler emissions, so it is an attractive option for coal plant operators in non-attainment areas. Modifying boilers to burn 100 percent solid biomass fuel is also an option for these plants. Biomass gases, whether obtained from an anaerobic digester, landfill or gasifier, can be applied to a wide variety of CHP applications compared to solid biomass fuels, which are primarily limited to boilers. This section analyzes both solid and gaseous forms of biomass in terms of their current uses, limitations, economics, and potential markets.

\footnotetext{
${ }^{12}$ U.S. Billion Ton Update: Biomass Supply for a Bioenergy and Bioproducts Industry, United States Department of Energy, August 2011.

${ }^{13}$ Database of State Incentives for Renewables \& Efficiency, Federal Incentives/Policies for Renewables \& Efficiency. Renewable Electricity Production Tax Credit (PTC), June 2012. http://www.dsireusa.org/incentives/incentive.cfm?Incentive_Code=US13F\&re=1\&ee=1

${ }^{14}$ Ibid. See also the full text of IRS Notice 2013-29.

${ }^{15}$ Database of State Incentives for Renewables \& Efficiency, Federal Incentives/Policies for Renewables \& Efficiency, Business Energy Investment Tax Credit (ITC), June 2012. http://www.dsireusa.org/incentives/incentive.cfm?Incentive_Code=US02F\&re=1\&ee=1
} 


\subsubsection{Anaerobic Digester Gas}

Anaerobic digester gas (ADG) is a gas produced from the decomposition of organic material by bacteria in the absence of oxygen. An anaerobic digester is a sealed, heated enclosure that provides a suitable environment for naturally occurring anaerobic bacteria to convert waste into methane gas. The source material can be wastewater (public sewage or industrial), animal manure, or other organic waste sludge. The bacteria consume the waste and break it down into a methane-based gas, in the process removing harmful constituents. The gas produced by the bacteria, typically 50-80 percent methane and 20-50 percent carbon dioxide, is usually flared and/or used as a heat source for the digester tank. It also has the potential to be a steady and reliable source of fuel for CHP.

The process by which anaerobic digester gas is produced and treated is shown in Figure 7. First, the organic sludge is stored, thickened and heated. Then it enters the digester tank, where anaerobic bacteria consume the sludge and release a methane gas that is collected and treated to remove contaminants. The treated gas can be fed to a prime mover to produce heat and electricity. Some of the heat produced can be used to preheat the sludge.

Anaerobic digester gas has a Btu content of about 600 $\mathrm{Btu} / \mathrm{ft}^{3}$ (approximately 60 percent that of natural gas). Any of the typical CHP technologies normally fueled by natural gas can be modified to run on anaerobic digester gas. The most common ADG-fueled CHP technologies are reciprocating engines, microturbines and fuel cells. Combustion turbines can be used, but only at large wastewater treatment plants

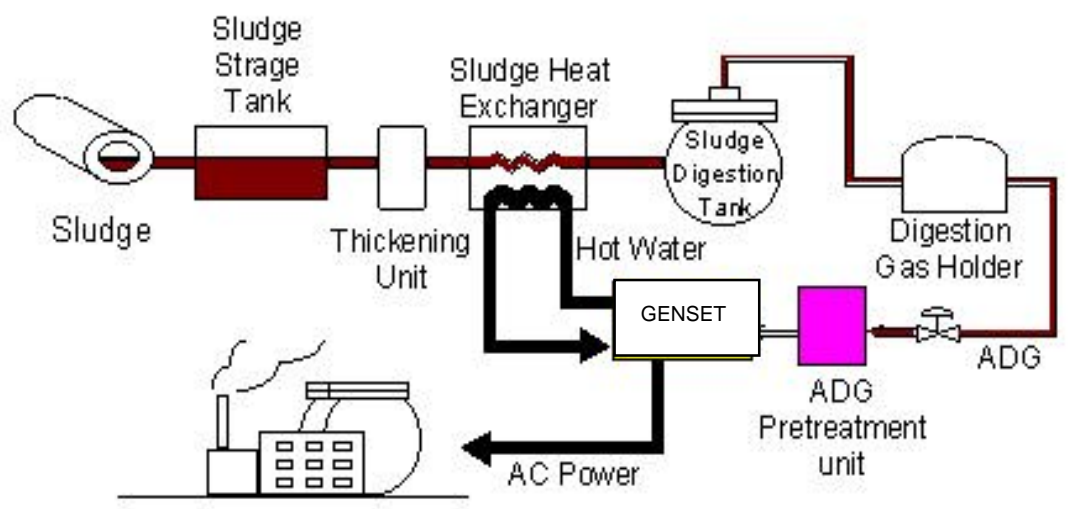

Figure 7. The Anaerobic Digestion Process: Converting Waste to Energy Source: www.toshiba.co.jp/product/fc/fce/adg.htm

that can produce over $1 \mathrm{MW}$ of power with ADG. Natural gas boilers can also utilize ADG in steam turbine applications, with few (if any) boiler modifications required, although steam turbines are not typically employed at wastewater treatment plants.

\subsubsection{Current Status}

There are over 75,000 wastewater treatment plants (industrial and municipal) in the United States, although only about 5,000 currently contain anaerobic digesters, and only about 2,000 are likely large enough to economically support ADG energy projects. ${ }^{16}$ Most industrial treatment plants use aerobic digestion, since it is the traditional method of treating organic wastewater streams, and these facilities

\footnotetext{
${ }^{16}$ United States Environmental Protection Agency, 2008 Clean Watersheds Needs Survey (municipal plants) and 2011 Envirofacts Database (industrial plants) - sites processing more than 1 million gallons per day
} 
already have aerobic treatment systems in place. The most common industries that utilize anaerobic wastewater treatment are food and beverage processing, pulp and paper mills, and chemical plants. ${ }^{17}$ Many smaller industrial plants simply send their wastewater to local municipal treatment facilities, which also mostly utilize aerobic digestion.

While aerobic digesters are well established, anaerobic digesters offer many potential benefits to plant operators. With anaerobic digestion, less solid waste remains, no power is required to aerate the wastewater, and recoverable energy is produced in the form of methane gas. However, the startup time for an anaerobic system is much greater, especially when the organic waste volume is low, so a steady, non-dilute stream of wastewater sludge is required for continuous operation. Because of this, anaerobic digesters are best suited for larger facilities with a relatively constant, high-volume organic waste stream.

According to the 2008 Clean Watersheds Needs Survey, only a fraction of these treatment plants with digesters utilize their ADG, usually to provide heat for the digester tank. ${ }^{18}$ About 100 of these plants are known to utilize their gas for CHP installations. ${ }^{19}$ Fuel cells operating on digester gas are a promising new application, having been successfully implemented in demonstration projects at municipal treatment plants in several U.S. locations. However, high installation and maintenance costs have been found to hinder fuel cell economics, and several of these plants have since implemented other utilization methods.

Aside from wastewater treatment plants, some large animal farms in the United States utilize anaerobic digestion to treat waste manure. Farms using anaerobic digesters to treat cow and hog waste produce less emissions and odors than conventional treatment methods, which usually let the waste decompose naturally or in a covered lagoon. Several farms have recently turned to anaerobic digestion to treat their waste, and many of these farms benefit from on-site power production, typically using small engines and microturbines.

\subsubsection{Economics and Market Considerations}

Anaerobic digester gas could conceivably be sold at the same rate as natural gas on a Btu-basis, but facilities are much more likely to use the gas for their own heat and power needs. When a digester is already in place, treated ADG is a fuel source available to plant operators, and when one is not in place, many benefits other than power production can be realized. ADG is higher in methane content and typically performs slightly better than landfill gas, coke oven gas, and the other low-Btu gases, and can replace natural gas in almost any prime mover technology, although some equipment modifications may be required. In addition, fuel treatment is typically required to remove moisture, particulates, and other contaminants that could foul the prime mover. This section examines the economics and market considerations for wastewater treatment plants and farms that could produce heat and power from anaerobic digester gas.

\section{Wastewater Treatment Plants}

There are over 16,000 municipal wastewater treatment plants, and considerably more industrial wastewater treatment plants in the United States, although only a few thousand are capable of CHP projects either because of their small size (municipal plants) or their wastewater content (industrial

\footnotetext{
${ }^{17}$ Kleerebezem, Robbert and Herve Macarie, “Process Wastewaters: Anaerobic’s Bigger Bite”, Chemical Engineering, April 2003.

${ }^{18}$ United States Environmental Protection Agency, 2008 Clean Watersheds Needs Survey, http://water.epa.gov/scitech/datait/databases/cwns/2008reportdata.cfm

${ }^{19}$ Combined Heat and Power at Wastewater Treatment Facilities: Opportunities and Operational Experience, U.S. Environmental Protection Agency, Combined Heat and Power Partnership, August 2011.
} 
plants). Municipal wastewater treatment plants, particularly ones large enough for ADG-fueled power generation, tend to be located close to large population centers. Industrial plants capable of utilizing anaerobic digestion (primarily food processing facilities, pulp and paper mills, and chemical plants) are concentrated in the Southeast and the Midwest. Although most WWTPs employ treatment methods other than anaerobic digestion, many already have digesters installed for wastewater treatment. These plants would only need to install a genset and fuel pretreatment equipment in order to begin producing power.

For wastewater treatment plants with aerobic digesters (a different digestion process), installing an anaerobic digester can provide many benefits such as improved odor control and less leftover sludge waste. In addition, no power is required to aerate the wastewater sludge, so all of the power produced from ADG can be used for the treatment plant's needs. For wastewater treatment plants that do not currently utilize anaerobic digestion, installing a digester-generator combination could prove beneficial, although the footprints of anaerobic digesters are large, and capital costs are considerably high.

\section{Animal Farms}

Anaerobic digesters are sometimes used to treat manure and other organic waste from dairy, hog, and poultry farms. Compared to other treatment methods, fewer emissions and odors are produced and less waste is left behind, but the cost of an anaerobic digester is often prohibitive for small and struggling farms. This makes anaerobic digesters most attractive to large farms with heavy waste streams - in addition, these farms are the ones with the highest power demand. An alternative for small farms could be piping or trucking the manure to a common location where a project developer can build, own and operate a digester-based DG/CHP system. Each ton of animal waste yields substantial amounts of gas per digestion cycle, which lasts about one month when operating at $95^{\circ} \mathrm{F}$. Most large commercial farms produce hundreds of tons of animal waste each year, and could generate much more power than what is demanded on-site.

For many farms, the cost to obtain, operate and maintain a digester-generator system is not matched by the benefits they would gain using the electric and thermal output onsite. However, a number of coproducts have emerged in recent years that can strengthen project economics, including tipping fees from food processing waste, renewable energy credits, and using digested fiber as a peat moss or fertilizer replacement. Fats, oils and greases have been increasingly incorporated into farm-based digester projects, and they can significantly improve economics with tipping fees and increased digester gas output. If a farm-based ADG project qualified with PURPA as a small power-producing facility, it could sell excess electricity to the local utility. Meanwhile, heat from a CHP unit can be sold to nearby greenhouses. Community digesters, hauling in manure from multiple farms, would be more economically viable with these co-products, and these types of projects are being investigated by farms and third party developers.

Power purchase agreements between utilities and small power generators like farm-based ADG CHP systems have become standard in some parts of the country, especially in areas like the South and Midwest where power costs are relatively low. A power purchase agreement can eliminate uncertainty for farms that are not capable of utilizing all of the electricity that they produce. Net metering excess electricity can also help project economics, and many states have rules that require utilities to offer net metering for farm ADG applications.

\subsubsection{Environmental Issues}

Anaerobic digester gas can be considered a renewable source of energy, since waste is always being created, and it qualifies as a renewable energy resource in most state renewable portfolio standard (RPS) programs. Anaerobic digesters reduce the odor, pathogens, water and air pollution associated with waste 
sludge. During combustion, carbon monoxide, nitrous oxides, organic compounds, and some dioxins are produced, but the formation of these pollutants can be minimized with a well-designed combustion process and emission control technologies. Anaerobic digesters can pose a potential safety risk, as they can pose an immediate threat to any human life that enters the container due to the high levels of hydrogen sulfide and ammonia, especially since all oxygen is sealed out. The container must be thoroughly cleaned and vented prior to entry.

\subsubsection{Availability, Cost, and Installed Capacity Data}

Availability: Anaerobic digester gas is made available from sources that utilize anaerobic digestion mostly some farms and wastewater treatment plants. There are about 100 ADG-generator systems currently in operation; however, there is a strong potential for market growth. There are over 75,000 wastewater treatment plants in the United States, and while only a small fraction contain anaerobic digesters, many more of them could potentially benefit from ADG as a fuel. ${ }^{20}$

Costs: An anaerobic digester consists of storage devices, a sealed tank, and gas collection and transportation equipment, and installation costs typically range from $\$ 1,000$ to $\$ 3,000$ per $\mathrm{kW}$ depending on the system. The digester does require occasional cleaning and maintenance, costing about $\$ 0.001$ to $\$ 0.003$ per kWh on top of genset maintenance. However, many treatment plants and some farms already operate digesters because of odor control and solids reduction benefits. These facilities only need to install a genset and gas treatment equipment to convert the flared (or boiler) gas into heat and electricity. Almost any natural gas CHP technology can be used, and usually only slight modifications are required. Fuel treatment may be necessary to remove moisture, particulates, and other contaminants. These systems can add $\$ 250-\$ 2,500 / \mathrm{kW}$, depending on the size of the genset and the level of fuel treatment required. Economies of scale are very important, and small pretreatment systems (for a 20-30 kW unit) can cost up to 10 times more per kW compared to systems for units over $5 \mathrm{MW}$ in size.

Installed Capacity (Non-Utility): There are about 100 ADG CHP installations, primarily small engines, collectively producing $248 \mathrm{MW}$ of electricity as of $2011 .^{21}$

\subsubsection{The Bottom Line}

Anaerobic digester gas is an established yet promising opportunity fuel. It is a good energy source for onsite power generation using reciprocating engines, fuel cells, or microturbines, and excess electricity can sometimes be sold to local utilities. Most farms do not demand enough power to warrant a CHP project based solely on their own consumption, unless net metering or partnership with a utility or third party are options. However, industrial and municipal wastewater treatment plants make very strong candidates for CHP applications using ADG.

\footnotetext{
${ }^{20}$ New Technology from MagnaDrive Corp. Offers Dramatic Energy Savings to Water/Wastewater Treatment Industry, MagnaDrive News Releases, May 2006. http://www.magnadrive.com/news/news-121200.shtml

${ }^{21}$ Combined Heat and Power at Wastewater Treatment Facilities: Opportunities and Operational Experience, U.S. Environmental Protection Agency, Combined Heat and Power Partnership, August 2011.
} 


\subsubsection{Biomass Gas}

Biomass gas is the fuel obtained when solid biomass is converted to fuel gas with a gasifier. Depending on the carbon and hydrogen content of the biomass and the gasifier's capabilities, the heating value of the gas can range anywhere from 150 to $800 \mathrm{Btu} / \mathrm{ft}^{3}$ (15 to 80 percent that of natural gas). Gasifier technologies extract volatile fuel vapors from solid fuels, leaving ash and other small particulates behind. Gasifiers that are currently in use produce a low-Btu gas, typically in a close-coupled boiler configuration that eliminates the need for hot gas cleanup. ${ }^{22}$ These systems have only been used for steam generation at facilities that produce industrial waste, such as the Shaw Waste to Energy facility in Dalton, Georgia that utilizes carpet waste, laminate wood flour, and other waste products in a close-coupled system.

Advanced gasifiers make use of a process called pyrolysis, which releases the volatile components of a fuel at about $1,000{ }^{\circ} \mathrm{F}$ via a series of complex reactions. Biomass fuels are an ideal choice for pyrolysis, since they have so many volatile components. In addition, a second gasification process can be employed, converting the leftover char into a carbon gas using steam and/or combustion. Because of this efficient conversion process, high quality biomass gas from advanced gasifiers tends to have a heat content near $600 \mathrm{Btu} / \mathrm{ft}^{3}$, and can be used in existing gas engines and turbines. With advanced gasifiers, about 80 percent of the volatile contents of a fuel are recovered in the gas. Small-scale gasifiers do not typically utilize the second step of the process, and they employ simpler gasification methods. As a result, the gas is typically lower in energy (150-250 Btu/ $\mathrm{ft}^{3}$, depending on the efficiency of the gasifier and the quality of the feedstock).

The most efficient method of utilizing biomass gas is a combined cycle advanced gasification system. ${ }^{23}$ Steam from a secondary turbine is used in the gasification process to produce biomass gas for the primary combustion turbine (see Figure 8). Similar gasifiers can be used to power reciprocating engines, but generally these systems are only cost-effective in large power applications. ${ }^{24}$ With smaller CHP units, the relatively low power output would not be able to justify the gasifier's high capital cost, which is estimated to range from $\$ 2,000 / \mathrm{kW}$ to $\$ 4,000 / \mathrm{kW} .^{25}$ More simple (but less efficient) gasifier systems have been developed by companies like Primenergy and Nexterra for smaller CHP applications with low-quality wood waste fuels. While these units can be used with close-coupled boilers for steam generation, a higher quality and more flexible biomass gas is necessary for the CHP market.

\footnotetext{
${ }^{22}$ Massachusetts Technology Collaborative, Advanced Technology Assessment, 2.0 Advanced Biomass Conversion Technologies, Black and Veatch, January 2008.

23 Ibid.

${ }^{24}$ McHale \& Associates, Biomass Technology Review, prepared for Biomass Power Association, October 2010.

${ }^{25}$ Biomass Catalog of CHP Technologies, Energy and Environmental Analysis, Inc. and Eastern Research Group, Inc., prepared for U.S. EPA CHP Partnership, 2007.
} 


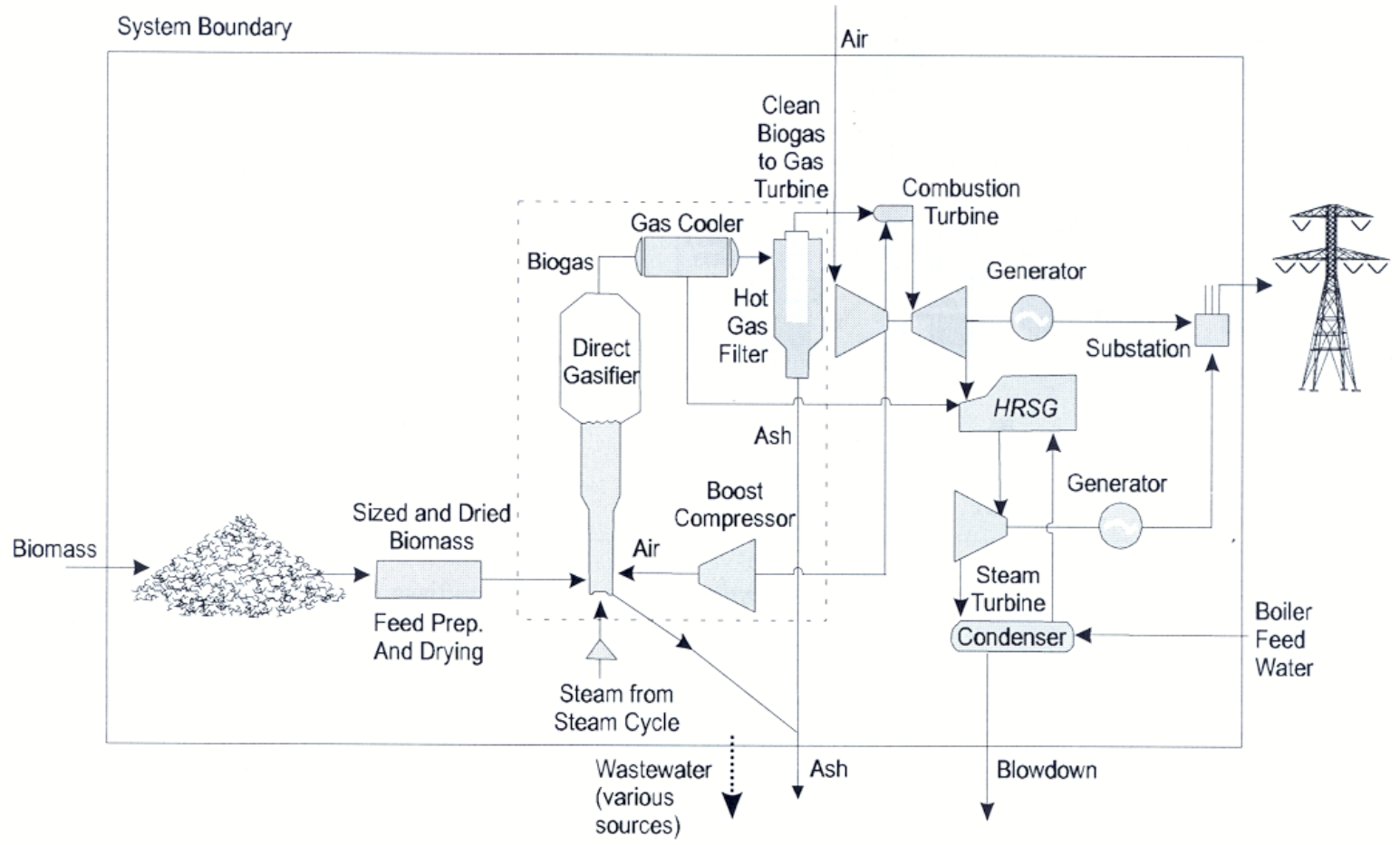

Figure 8. Combined Cycle Gasification System

Source: www.eren.doe.gov/power/pdfs/bio_gasification.pdf

\subsubsection{Current Status}

Biomass gas is not yet widely used as an energy source, because a cost-effective, efficient gasifier that reliably produces high-quality biogas has not yet been developed. The installation cost for gasifiers is simply too high at this point, and the product gas requires cleaning before it can be used. This is a more difficult task than with other medium-Btu gases, however, as the product gas is collected at an extremely high temperature, and hot gas cleanup is a difficult and resource-intensive process. Still, several companies, such as Nexterra ${ }^{26}$ (Vancouver) and Taylor Biomass Energy (New York), are working on proprietary gasification systems that could break the commercial barrier and impact the CHP market. The increased efficiency and energy output of a gasification system could potentially offset the additional costs when compared to directly burning solid biomass fuels in a boiler-steam turbine configuration. Also, biomass gas units produce much less $\mathrm{NO}_{x}, \mathrm{CO}_{2}$ and particulate matter than directly combusting the solid fuel.

To date, biomass gasification systems have been used primarily with mill residue and crop residues, where plant owners have a free fuel source that would otherwise have to be disposed of. Generally there have been two types of gasifiers: demonstration units with large combined cycle turbines, and smaller gasifiers used for steam generation and process heating in close-coupled systems. Although some of the large applications have had success with combined cycle units producing over $50 \mathrm{MW}$, their gasification systems are generally too expensive for CHP implementation. Smaller units that produce low quality biomass gas have proven successful in countries like India that lack fossil fuel resources, as well as some small heating applications with waste fuels in the U.S., but the potential for CHP applications using these types of gasifiers is limited. Finally, Nexterra has sited a biomass gasifier powering a $2 \mathrm{MW}$

\footnotetext{
${ }^{26}$ McHale \& Associates, Biomass Technology Review, prepared for Biomass Power Association, October 2010.
} 
reciprocating engine at the University of British Columbia. ${ }^{27}$ Some see this approach as a bridge to commercial acceptance of more advanced biomass gasifiers, but this is still a demonstration project and will need to be followed by proven commercial applications.

Currently the high capital costs of advanced gasifier systems and the lack of proven commercialized units are the biggest hindrances to the widespread utilization of biomass gas, and it is uncertain if these drawbacks will be properly addressed in the near future. Biomass gasification was once seen as a promising up-and-coming technology, but difficulties with gasifier performance and hot gas cleanup, along with decreasing natural gas costs, have recently caused the development of advanced gasification systems to slow. A recent plan by Xcel Energy to seek approval of a biomass gasification plant as a demonstration project in Colorado provides further evidence of the lack of progress into commercial status of this technology. ${ }^{28}$

\subsubsection{Economics and Market Considerations}

Gasifier technology adds considerably to the installed cost of any power generation system. When all gas cleaning equipment and installation costs are considered, advanced gasifiers are projected to cost about $\$ 2,000-\$ 4,000$ per $\mathrm{kW} .{ }^{29}$ Facilities that have justified the cost of a gasifier are typically large (over 40 MW) because small biomass gasification systems are generally not economical. While CHP systems under $20 \mathrm{MW}$ can be beneficial in applications with a free fuel source, larger systems have proven themselves to be more cost-effective.

The main markets for biomass gas at its current state are large industrial applications, utilities, and facilities with a local or on-site biomass source. Most gasification systems are close-coupled with boilers to directly utilize the hot gas. In order for biomass gas to become a serious contender in the CHP market, advanced gasifiers need to become commercially viable, with an economic method of cleaning the hot gas so it can be used in various CHP configurations. Total gasifier installed costs would likely need to settle at $\$ 1,000 / \mathrm{kW}$ or less with commercial availability shown to be achieved.

\footnotetext{
${ }^{27}$ Nexterra, VBC and GE Celebrate the Opening of Groundbreaking Renewable Biomass CHP System - A First in North America, Press Release, September 13, 2012.

${ }^{28}$ Xcel Energy Seeks Biomass Gasification Demonstration Facility, Biomass Magazine, May 21, 2013.

${ }^{29}$ Biomass Catalog of CHP Technologies, Energy and Environmental Analysis, Inc. and Eastern Research Group, Inc., prepared for U.S. EPA CHP Partnership, 2007.
} 


\subsubsection{Environmental Issues}

Biomass gas, when produced from an efficient, state-of-the-art gasifier, burns just as cleanly as natural gas. The particulates and contaminants of biomass gas will change depending on the quality and type of gasifier used, and the feedstock utilized - some types of biomass produce a great deal of tar that must be removed. Filters will usually suffice for gas cleaning, but control technologies may be required for $\mathrm{NO}_{\mathrm{x}}$ emissions in non-attainment areas.

\subsubsection{Availability, Cost, and Installed Capacity Data}

Availability: There is an estimated 400 million dry tons of biomass available for fuel in the United States. ${ }^{30}$ Only a small fraction of this biomass, however, can be obtained at a competitive price on a perBtu basis.

Costs: Biomass generally costs $\$ 20-\$ 50$ per dry ton to obtain, which translates to about $\$ 1.50-\$ 3.00$ per million Btu for the solid fuel. ${ }^{31}$ Transportation costs must be added to these prices. Gasifiers are currently expensive, on the order of $\$ 2,000-\$ 4,000$ per $\mathrm{kW}$, plus additional maintenance costs of 0.0010.005 cents/kWh.

Installed Capacity (Non-Utility): Biomass gas was accountable for $240 \mathrm{MW}$ of U.S. installed capacity in the year 2012, although nearly all of this capacity comes from anaerobic digester gas, which is included in the same category. ${ }^{32}$

\subsubsection{The Bottom Line}

While high-efficiency combined cycle biomass gasification systems have proven themselves costeffective in some large utility-scale operations, the technology is generally not suitable for smaller CHP applications. Expected advancements in gasification technologies have not occurred, largely because the recent drop in natural gas prices has reduced the demand, but also because installation and maintenance costs are simply too high for most industrial sites. With the lack of a commercialized economical advanced gasification system, and lowered expectations for future progress in this area, biomass gas will not be considered for further analysis in this report.

\subsubsection{Black Liquor}

Black liquor is a byproduct of the Kraft pulping process used to produce pulp for paper. During pulping, wood fibers are separated and treated to produce a pulp, which is then converted into paper. With chemical pulping, the lignin in wood is dissolved in a digester, which separates the fibers and creates

\footnotetext{
${ }^{30} \mathrm{Haq}$, Zia. Biomass for Electricity Generation. United States Department of Energy - Energy Information Administration. May 2006. http://www.eia.doe.gov/oiaf/analysispaper/biomass/index.html

${ }^{31}$ U.S. Billion-Ton Update: Biomass Supply for a Bioenergy and Bioproducts Industry, United States Department of Energy, August 2011.

${ }^{32}$ U.S. Energy Information Administration Form EIA-860 Database Annual Electric Generator Report, 2012.
} 
black liquor, a tar-like substance, as a waste product. Black liquor is an organic material consisting mainly of carbon, oxygen and sodium, and can be recovered and used as a fuel to generate heat and power. Pulp and paper mills also produce a waste sludge that can be used as a solid fuel, and this is covered in the "sludge waste" section.

Black liquor is usually incinerated in special recovery boilers that recover any remaining chemicals and generate steam and electricity for the pulp or paper mill. Boilers designed for fuel oil and coal can be modified to accommodate black liquor. Gasification is another option, which produces a fuel gas that can power a gas turbine with a relatively high efficiency. Although gasification-systems burn cleaner and achieve higher efficiencies, their capital cost is also much higher.

\subsubsection{Current Status}

For CHP gensets larger than $1 \mathrm{MW}$ in size, black liquor accounts for more thermal output than any fuel besides natural gas. ${ }^{33}$ This is due to the widespread use of black liquor for generating heat and power at paper mills. Most pulp and paper mills utilize their black liquor to generate additional steam for the plant. Some mills also produce electricity, and sell excess power to a local company or power utility. Excess black liquor can be sold as a fuel if there is a nearby market such as a neighboring paper mill, but in most cases all of the black liquor is used on-site at the mill.

\subsubsection{Economics and Market Considerations}

Most pulp and paper mills use all of their black liquor to provide for onsite heat and power needs. While excess black liquor could be available, its scarcity and the lack of a supporting distribution infrastructure keep the fuel from being a serious candidate for outside markets. In general, black liquor energy is limited to pulp and paper mills, and possibly their surrounding facilities.

\subsubsection{Environmental Issues}

Black liquor, which comes from the pulp and paper derived from trees, can be considered a renewable resource. Black liquor contains some sulfur and small amounts of nitrogen, so $\mathrm{SO}_{\mathrm{x}}$ and $\mathrm{NO}_{\mathrm{x}}$ emissions are potential concerns with using this fuel for CHP. Emission control technologies may be needed in some areas.

\subsubsection{Availability, Cost, and Installed Capacity Data}

Availability and Cost: Black liquor is produced at paper mills with pulping operations, but the majority is already used as an energy source by the mills themselves. The amount of excess black liquor produced at these mills is inconsequential. It is rarely sold for outside consumption.

\footnotetext{
${ }^{33}$ Ibid.
} 
Installed Capacity (Non-Utility): Black liquor accounted for 4.5 GW of U.S. electric capacity in the year 2012, from 163 installations. ${ }^{34}$ These numbers have remained relatively steady for the past decade. Black liquor is also heavily utilized in thermal applications.

\subsubsection{The Bottom Line}

Black liquor is a proven opportunity fuel, already extensively used by pulp and paper mills, especially for steam generation. If a market were to develop, it could potentially be sold as an alternative boiler fuel. However, pulp and paper mills already utilize most of their black liquor, and the cost of transporting the fuel would likely eliminate any potential benefits.

\subsubsection{Crop Residues}

Crop residues are materials that remain after crops have been harvested and/or processed. Bagasse (sugar cane residue), rice hulls, rice straw, wheat straw, nutshells, and prunings from orchards and vineyards are all considered crop residues. They all have the potential to generate power, with an energy content ranging from 2,500 to 4,000 Btu per pound when the crop is wet (6,000-7,500 Btu per pound, dry). Crop residues are produced in abundance on nearly every farm in the U.S (see Figure 9).

When used as a fuel, crop residues are most often burned in boilers to create steam, although sometimes the residues are gasified. Existing coal boilers can be converted to burn solid cropresidue fuel in cofiring blends with few necessary modifications. Cofiring with coal is a common practice that increases the plant's net heat rate and decreases $\mathrm{SO}_{\mathrm{x}}$

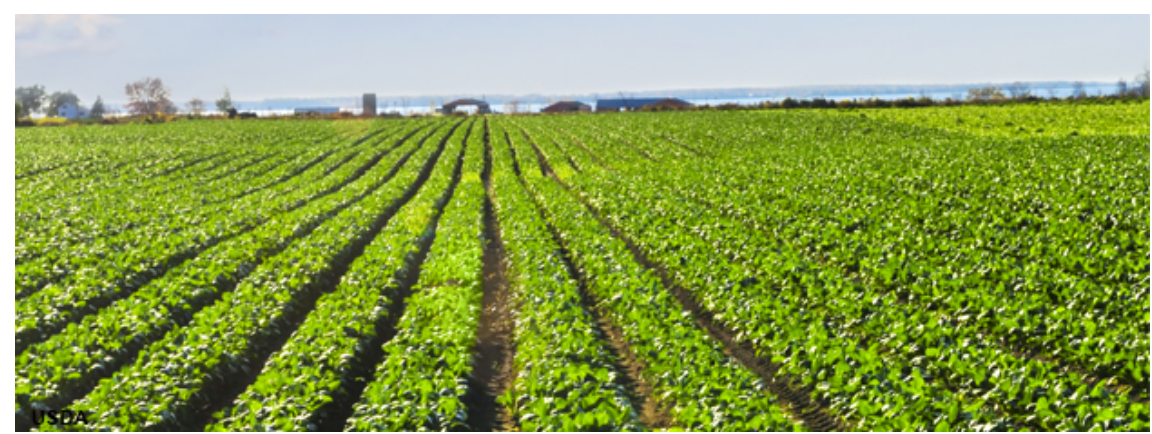

Figure 9. Crops Produce Residues That Can Be Used As A Fuel (Source: www.ers.usda.gov) and $\mathrm{NO}_{\mathrm{x}}$ emissions. Crop residues can also be used as a primary fuel, but a coal-fired boiler would require many modifications and adjustments. As with most steam turbine applications, crop residues are better suited for large industrial or utility operations, and as with most solid biomass fuels, cofiring with coal is usually the most attractive option.

\subsubsection{Current Status}

Due to high moisture content, varying availability, and relatively high costs, crop residues are not a viable fuel alternative for most CHP applications. Crop residue fuels are generally only favorable is when the prime mover is located very close to the site of crop production, and when the collection of residues can

\footnotetext{
${ }^{34}$ Ibid.
} 
be incorporated into farm operation. Otherwise, the cost of collecting and transporting the residues is often too high.

\subsubsection{Economics and Market Considerations}

Due to the high costs associated with collecting and transporting crop residues, their market price is often considerably higher than fossil fuels, as well as other biomass fuel sources. There are large variations in price depending on crop availability and region. Most areas do not have an infrastructure for gathering, brokering and shipping crop residues. The Federal government has initiated programs in the past to provide financial incentives and operating cost reductions to crop residue users, although these federal incentives have expired. However, state loans, grants, credits and tax exemptions are available in some areas.

At the present time, there is no market for trading crop residues for use as a fuel. The availability and quality of the residues are highly regional. Some contractual relationships exist to purchase crop wastes for fuel in certain areas, but they are very limited. Seasonality, including possible floods and droughts, is another issue that can affect availability and quality. In order for a market to exist, there must be an efficient and established system of gathering, brokering and transporting the crop residue fuels. Dedicated energy crops (crops grown specifically for the production of crop residue as a fuel) would likely be required for such a market to be maintained. Currently, no such infrastructure exists.

\subsubsection{Environmental Issues}

Using crop residues as a fuel is beneficial to the environment relative to disposal by open burning. The controlled burning of crop residues for power generation removes up to 98 percent of emissions that occur in an uncontrolled, open burn (many farmers burn their crop residues as waste). The sulfur and nitrogen content in crop residues is much lower than in coal, so coal-fired plants would benefit from cofiring, and the ash content for most crop residues is generally lower than coal, but higher than woody biomass fuels.

\subsubsection{Availability, Cost, and Installed Capacity Data}

Availability: The average annual tonnage of crop residue production between 1998 and 2007 exceeded 350 million dry tons, although most of this could not be collected and transported economically. At a cost of less than $\$ 40 /$ dry ton, it is estimated that less than 30 million dry tons would be available on an annual basis. $^{35}$

Costs: Most crop residues cost between $\$ 30$ and $\$ 60$ per dry ton to obtain (averaging about $\$ 3.00$ per MMBtu, plus transportation costs. ${ }^{36}$ According to EIA, coal costs between $\$ 1.25$ and $\$ 2.50$ per MMBtu for manufacturing facilities to obtain, so crop residues will have a tough time competing with coal in most markets.

\footnotetext{
${ }^{35}$ U.S. Billion-Ton Update: Biomass Supply for a Bioenergy and Bioproducts Industry, United States Department of Energy, August 2011.

${ }^{36}$ Ibid.
} 
Installed Capacity (Non-Utility): Crop residues, categorized as agricultural byproducts, accounted for 414 MW of electric capacity in the year 2012. ${ }^{37}$

\subsubsection{The Bottom Line}

The lack of a market infrastructure along with high collection and transportation costs will likely limit the use of crop residues to cofiring applications and regional use.

\subsubsection{Food Processing Waste}

Food processing waste (FPW) consists of any wastes generated in the food processing industry that can be used for fuel. Potato waste, cheese whey wastes, fruit pits, leftover sludge, and other energy-rich wastes can all be converted into a solid biomass fuel. The waste can be dried and cut into chips to be fired in a boiler (similar to coal). Cofiring is usually preferred, as it reduces the emissions in a coal-fired plant and no boiler modifications are necessary. To create a gaseous fuel, anaerobic digestion can be used - the food waste is stored in an oxygen-deprived tank, where anaerobic bacteria consume it and release a methane gas. This method is often used to extract energy from (and dispose of) leftover fats, oils and greases. To create a liquid fuel, certain food wastes can be fermented and distilled into ethanol. Different types of wastes will produce different types of fuel, and even the same food waste can be used in very different ways, which makes it hard to categorize certain characteristics of food processing waste as a fuel. In this section, only solid food processing waste is considered (see ADG and Biomass Gas for information on its gaseous forms).

\subsubsection{Current Status}

Aside from a handful of food processing facilities and certain research projects, solid food processing waste is not generally used as a fuel for CHP projects. Despite its many potential benefits, FPW has yet to gain widespread acceptance or appeal. One problem is that currently most FPW has high moisture content (over 50 percent), and it is disposed as industrial wastewater and discharged to the local treatment plant. Another problem is the varying characteristics and properties of different types of FPW, making it hard to consolidate into a consistent source of fuel. Still, certain waste streams would make ideal fuel sources for the plants that produce them, and there could be a good amount of potential in the food processing industry.

\subsubsection{Economics and Market Considerations}

Food processing waste utilization can significantly reduce fuel costs for food processing facilities. While some processing costs may be incurred in drying and cutting the waste into chips, FPW is essentially a free fuel source for the food processing industry. Federal and state government incentives may be offered to users of the fuel, and cofiring is a cost-saving option for those already utilizing a coal-fired boiler.

There is virtually no market for food processing wastes as a fuel, except for in the food processing industry. It is environment-friendly and performs fairly well when processed, but due to the large

\footnotetext{
${ }^{37}$ U.S. Energy Information Administration Form EIA-860 Database Annual Electric Generator Report, 2012.
} 
variations in the types of waste and fuels produced, and the lack of a distribution infrastructure, it would be difficult to produce a consistent quality product on a large scale. It is possible that nearby plants may want to purchase the waste for cofiring in a coal-fired boiler or some other application. If so, the waste would sell for about the same rate as coal on a Btu-basis.

\subsubsection{Environmental Issues}

Food processing waste is a renewable energy source that burns cleaner than fossil fuels. When FPW is gasified, the release of methane gas is prevented, and the waste left behind makes an excellent fertilizer. Chlorine is a concern with some forms of FPW, such as oat hulls, and ash content can be relatively high for some types of food processing waste. Overall, however, there are very few negative environmental impacts of using food processing waste as a fuel.

\subsubsection{Availability, Cost, and Installed Capacity Data}

Availability: There is a large amount of food processing waste created every year . Fruit pits, nutshells, oat hulls, and other forms of food waste are produced in abundance, so there could be a market among food producers. Oat hulls are currently used to produce power at the University of Iowa, the University of Minnesota, and a St. Paul, Minnesota district heating plant, so this practice is beginning to catch on in the Midwest.

Costs: If the fuel is sold as a solid, the price would be competitive with coal on a Btu basis ( $\$ 1.25$ to $\$ 2.50$ per MMBtu, delivered). Transportation costs would add about 40 cents per ton-mile. Some minor boiler equipment modifications may be necessary.

Installed Capacity: Unknown, but it is believed that the current installed capacity of FPW is minimal, limited to a few plants in the Midwest.

\subsubsection{The Bottom Line}

Food processing wastes can produce a high quality and clean-burning fuel for a relatively low price, but the wide variety in the waste and fuel types and the lack of a market infrastructure prevents its widespread use. Food processing waste can come from a variety of sources, and utilize a number of different generation technologies. Potential candidates are hard to generalize and must be evaluated on a case-bycase basis.

\subsubsection{Forest Residues}

Forest residues, also known as harvested wood, are most often collected from forest slash, or the residues that remain on the forest floor after logging operations. These tree branches, trunks and stumps can be collected and brought to the roadside for pickup. Forest thinnings, produced from efforts to minimize the spread of wildfires, are another type of forest residue that can be used as a fuel. The residues are cut into chips and dried before they are used as boiler fuel. Wood waste fuels (mill residues and urban wood 
waste) are considered separately in this report, as they are collected at industrial sites and wood recycling yards, generally costing less than forest residues that have been hauled to the roadside, and having a slightly different composition.

\subsubsection{Current Status}

The utilization of forest residues is currently limited to lumber mills, pulp and paper mills, and industrial sites and utility power plants located close to logging operations. Forest residues are often cofired with coal to reduce both fuel costs and plant emissions at these facilities. While utility boilers are used for power generation, most industrial boilers that use forest residues produce process steam for various facility operations, including some CHP applications. Instead of cofiring with coal, dedicated biomass boilers could be installed at these sites in locations with high forest residue densities. Back-pressure turbines and extraction turbines can then be used to produce renewable power while providing the desired pressure-drop for the steam.

\subsubsection{Economics and Market Considerations}

Forest residues from the logging and lumber industries are produced in large quantities in many areas of the country, but these areas tend to be rural, with a limited number of nearby industrial facilities to potentially utilize the fuel. The cost to pick up cords of forest residues at the roadside can vary, depending on how close the logging operations took place to the road, and how much labor was required to collect and transport the residues. In the Department of Energy's 2011 Billion Ton Update, significant quantities of forest residues were found to be available at average roadside collection costs under $\$ 20$ per dry ton, with even more quantities available at under $\$ 40$ per dry ton. ${ }^{38}$ These costs are low enough to compete with coal, natural gas, and utility electricity when it comes to combined heat and power operations with boilers and back-pressure or extraction steam turbines.

One potential source of wood fuel that has recently drawn interest is forest thinnings. Due to the wildfires that destroyed parts of Arizona, California and other states, forests with dangerous potential are now being thinned out so that fires won't start or spread as easily. Normally the wood waste from forest thinning is burned, but it could potentially be used as a fuel for boilers and gasification systems. McNeil Technologies recently conducted a study for Colorado's Office of Energy Management and Conservation titled "From Forest Thinnings to Boiler Fuel". According to the study, nearly 36,000 dry tons of biomass would be available from Summit and Eagle County's forest thinnings each year - enough fuel to produce over $3 \mathrm{MW}$ of electricity. However, the study concluded that delivered forest thinnings would cost nearly $\$ 100$ per dry ton on average to obtain - much too expensive to compete with other fuels. ${ }^{39}$ If a more efficient collection and transportation system were developed, the prices may go down, but it appears that forest thinnings do not offer any benefits over other wood waste fuels.

\footnotetext{
${ }^{38}$ U.S. Billion-Ton Update: Biomass Supply for a Bioenergy and Bioproducts Industry, United States Department of Energy, August 2011.

${ }^{39}$ From Forest Thinnings to Boiler Fuel. Western Regional Biomass Energy Program. World Wide Web, August 2004. http://www.westbioenergy.org/dec2003/06.htm
} 


\subsubsection{Environmental Issues}

While the long-term sustainability of forest residues as a fuel is debatable due to the slow growth period of cut-down trees, they are generally considered a renewable source of energy. Although carbon dioxide is produced in burning wood fuels for energy, with the growth of new trees, the net carbon dioxide emissions will approach zero. $\mathrm{SO}_{\mathrm{x}}$ and $\mathrm{NO}_{\mathrm{x}}$ emissions in forest residues are much less than coal so cofiring will help reduce emissions. Wood ash is non-toxic and does not contain pollutants or heavy metals, but some states still consider it hazardous waste.

\subsubsection{Availability, Cost, and Installed Capacity Data}

Availability: Forest residues are available wherever logging operations are taking place, which tends to be in remote locations. There are an estimated 56 million dry tons of forest residues available for fuel each year. $^{40}$

Costs: While collection and transportation costs are prohibitive for most forest residues, there is a substantial amount of residues available at less than $\$ 40$ per dry ton, and a more limited amount available at under $\$ 20$ per dry ton ${ }^{41}$ Transportation costs add about 40 cents per ton-mile, or about $\$ 10$ per ton for a 25-mile transport.

Installed Capacity: Solid wood waste: 3.9 GW of electric capacity in 2012, from 183 installations (although much of this is from wood waste produced at industrial facilities). ${ }^{42}$

\subsubsection{The Bottom Line}

Forest residues, available at lower costs than crop residues, could have strong potential as a solid biomass fuel. For industrial facilities that can obtain forest residues at an economical price, a biomass boiler with a back-pressure or extraction steam turbine could be a beneficial investment. Forest residues will be further explored in this report as a potential opportunity fuel for industrial CHP applications.

\subsubsection{Landfill Gas}

Landfill gas (LFG) is gas created by the decomposition of landfill waste, which is essentially an anaerobic digestion process. Accordingly, the gas is similar to ADG, containing about 50 percent methane and just under 50 percent carbon dioxide. In the past, LFG was simply collected and flared, but now many landfills are taking advantage of their waste gas, using it to produce heat and power. This cuts down on methane emissions and can potentially generate revenue for the landfill. In general, 1 million tons of municipal solid waste produces 300 cubic foot per minute of landfill gas that could generate 7,000,000

\footnotetext{
${ }^{40}$ Milbrandt, A. A Geographic Perspective on the Current Biomass Resource Availability in the United States. United States Department of Energy, National Renewable Energy Laboratory. Technical Report. December 2005.

${ }^{41}$ U.S. Billion-Ton Update: Biomass Supply for a Bioenergy and Bioproducts Industry, United States Department of Energy, August 2011.

${ }^{42}$ U.S. Energy Information Administration Form EIA-860 Database Annual Electric Generator Report, 2012.
} 
kWh of electricity per year, enough to power 700 homes. $^{43}$ Most of the candidates for LFG projects have more than 1 million tons of waste in place.

Developers such as INGENCO and Granger Electric/Energy typically purchase the rights a landfill's gas, transport it to a location where a genset can interconnect with the power grid, and sell the electricity to a third party or utility. Sometimes landfills will act as developers themselves, and sometimes the gas is directly pipelined to the facility where it will be used.

Landfill gas is similar to natural gas, but with less methane and much more carbon dioxide. The Btu content of landfill gas ( $\left.\sim 500 \mathrm{Btu} / \mathrm{ft}^{3}\right)$ is about half that of natural gas, but it can still generate a substantial amount of power, and only minor modifications and increased maintenance are required for existing equipment. Most LFG to energy applications utilize reciprocating engines in non-attainment areas where emissions are not an issue. In other cases, microturbines are sometimes used.

\subsubsection{Current Status}

Of the estimated 6,000 landfills in the United States, of which at least 2,500 are active, 477 currently utilize their landfill gas for electric power, with another 169 utilizing it for thermal applications. Over 50 more landfills have LFG-to-energy projects under construction, and about 1,800 have been identified as potential or candidate landfills. ${ }^{44}$ The EPA is encouraging the use of LFG to generate power through the Landfill Methane Outreach Program, which provides assistance and incentives to LFG-to-energy projects. With most of these projects, a third party developer pays for the rights to the landfill gas. They have the choice of installing and maintaining a generator at the landfill site (and marketing the electricity), pipelining the gas to another facility, or cleaning it up and selling it as a clean natural gas alternative. If the gas is piped to another facility, it can be used for steam or process heat, or used in a CHP application. Most LFG-to-energy projects to date have opted for utility electricity sales, because finding a nearby industrial site to utilize the gas can be a difficult task for many landfills.

\subsubsection{Economics and Market Considerations}

Untreated landfill gas generally sells for up to 20 percent of the cost of natural gas on a Btu basis, between $\$ 1$ and \$3 per MMBtu. The Federal government currently offers production or investment tax credits, and could potentially help finance LFG-to-energy projects. State governments often provide financial incentives as well.

The market for LFG utilization is generally limited to the areas immediately surrounding landfills. When the gas is pipelined, length and cost of pipeline is a concern, so landfill gas CHP units are usually limited to nearby industrial operations, or more commonly, electricity wholesale applications where the electric grid is nearby. Despite the high initial cost, some LFG-to-energy projects with pipelines longer than ten miles have become profitable CHP operations, thanks partially to state government incentives and financing.

\footnotetext{
${ }^{43}$ United States Environmental Protection Agency, Landfill Methane Outreach Program, August 2010, http://www.epa.gov/lmop/index.htm

${ }^{44}$ Ibid.
} 
Some projects have been structured around a third party developer who produces electricity at the landfill and sells it to the local utility. With these projects, the developer is often responsible for operating and maintaining the power generator at the landfill site. Electricity generated is sold for wholesale prices, plus the renewable energy credits can be sold, providing enough revenues to developers to support these projects. Landfills can also use their gas to meet their own heat and power needs, selling any excess electricity to the local utility, and some landfills have benefited from this practice.

\subsubsection{Environmental Issues}

Using landfill gas as a fuel is beneficial to the environment since it reduces the release of methane and carbon dioxide into the atmosphere (as opposed to flaring). According to the EPA, utilizing 1 million tons of waste for landfill gas energy has the same greenhouse gas impact as planting 8,300 acres of trees. ${ }^{45}$ LFG utilization also reduces unpleasant odors and explosion threats from landfills. Although not renewable in the classic sense of the word, LFG is often considered a renewable energy source by states and their RPS programs since garbage consists mostly of biomass and is always being created. Combustion of landfill gas for energy does produce some emissions, but they can be treated with available emission control technologies.

\subsubsection{Availability, Cost, and Installed Capacity Data}

Availability: Out of the 5,000-plus landfills in the United States, there are only 477 sites using LFG to produce electricity, and about 1,800 more have been identified as candidates for LFG projects. ${ }^{46}$

Costs: When landfill gas is sold, it is usually sold for 20 to 50 percent of the cost of natural gas on a Btu basis (minus transmission and delivery costs), coming out to about \$1-\$3 per MMBtu based on current natural gas pricing. ${ }^{47}$ Gas that has been cleaned and treated to near-natural gas quality can be sold for the local natural gas price. Gas collection and transport to the genset is almost always already in place since large landfills are required to collect and flare their gas. The only costs for onsite use, then, are associated with the genset (including fuel treatment equipment) and its maintenance. Pipelines and/or electric distribution lines would add to the cost.

Installed Capacity (Non-Utility): Landfill gas accounted for $2.0 \mathrm{GW}$ of electric capacity in $2012 .{ }^{48}$ A more recent estimate taken from the EPA's Landfill Methane Outreach Program database confirms this figure, with over $2 \mathrm{GW}$ of existing capacity in $2013 .^{49}$

${ }^{45}$ Ibid.

${ }^{46}$ Ibid.

${ }^{47}$ LFG Energy Project Development Handbook, U.S. Environmental Protection Agency, Landfill Methane Outreach Program, 2011.

${ }^{48}$ U.S. Energy Information Administration Form EIA-860 Database Annual Electric Generator Report, 2012.

${ }^{49}$ Landfill Methane Outreach Program Database, U.S. Environmental Protection Agency, Landfill Methane Outreach Program, 2013. 


\subsubsection{The Bottom Line}

Landfill gas can be an attractive energy source for landfills or nearby facilities that are large enough to employ the majority of the gas produced. While the quality is not as high as natural gas, using it conserves natural resources and is beneficial to the environment. In addition, in most states it is considered to be a renewable energy source, and thus offers promotional benefits.

\subsubsection{Municipal Solid Waste and Refuse Derived Fuel}

Municipal solid waste (MSW) is commonly referred to as trash or garbage (see Figure 10). It is normally collected at landfills and can consist of any type of refuse. The section on landfill gas describes how MSW is naturally converted into a gaseous fuel. In some areas, however, MSW is dried and combusted in high temperature boilers to generate steam and electricity. Some collection sites produce Refuse Derived Fuel (RDF), which is MSW that has been thoroughly sorted so that only energy-producing components remain. This fuel can either be burned in boilers or gasified, and it performs better than MSW, but it costs money to produce. In either case, post-combustion emission controls will need to be applied.

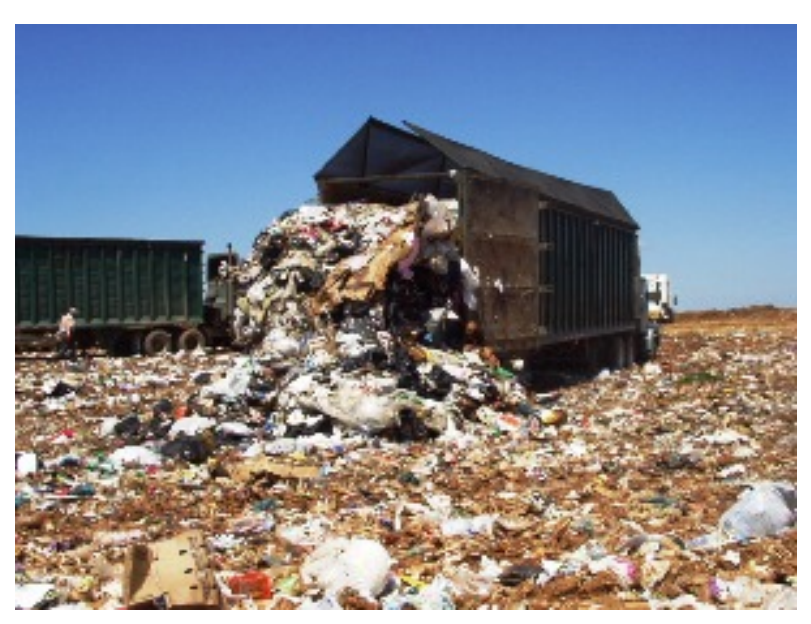

Figure 10. Municipal Solid Waste

(Source: $\underline{\text { http://www.wakegov.com) }}$
Major modifications must be made to existing coalfired boilers if MSW is to be used as a substitute. The heating value of MSW averages less than 5,000 $\mathrm{Btu} / \mathrm{lb}$ so much more ash and residue are left behind than coal, whose heating value is more than three times as high. Using a stoker-type boiler to incinerate the waste is usually the best choice, since they can burn MSW with the fewest modifications. Pollution control technologies, such as catalytic reduction and scrubbing, reduce NOx and SOx in the emissions by neutralizing the acidic gases. Filters are also employed to remove particulates and magnets are used to remove metal from the waste. Refuse derived fuel is handled more easily by boilers since most of the undesirable components have been removed prior to combustion.

The United Technologies Research Center compiled a report on biomass gasification using RDF. Overall, the findings were positive, and the researchers were able to employ a low-cost garbage collection, preparation, and gasification system that powered an advanced $85 \mathrm{MW}$ combined cycle gas turbine. $^{50}$ Since then, however, studies prepared for solid waste authorities such as Palm Beach County, Florida have concluded that such technologies are costly and present higher risk compared to conventional options such as stoker boilers. ${ }^{51}$

\footnotetext{
${ }^{50}$ Liscinsky, David. Biomass Gasification and Power Generation Using Advanced Gas Turbine Systems, Final Report October 2002. United Technologies Research Center. October 2002.

51 Berenyi, Eileen, Case Study: Palm Beach County, Florida Solid Waste Authority Waste to Energy Facility, Governmental Advisory Associates, Inc., 2009
} 


\subsubsection{Current Status}

In the United States, over 200 million tons of municipal solid waste is produced on an annual basis. MSW is the second largest biomass fuel source in the United States, behind wood-based fuels, producing 2.7 GW of power each year. ${ }^{52}$ Most of this energy comes from projects started in the 1970's, because of the oil embargo and worries about environmental pollutants from dumps and landfills. Baltimore and Montgomery County's 60 MW waste-to-energy facilities in Maryland are examples of MSW projects still operating. However, the combination of large new landfills and the EPA's support of LFG have slowed down solid waste to energy projects, and most older projects have been shut down.

\subsubsection{Economics and Market Considerations}

Because MSW is a solid fuel, it cannot be transported through pipelines or stored in pressure vessels. The heat content of the fuel is extremely low, so transportation can be very expensive. Because of this, MSW and RDF projects are best implemented at garbage collection sites, or at nearby facilities. Emission control technologies can be costly, but some state governments offer incentives for using MSW as a fuel. Excess electricity generated from MSW and RDF can be sold to nearby utilities or consumers. However, LFG projects are generally more efficient and profitable.

Municipal solid waste is not an ideal fuel source. The quality is unpredictable, and emissions can be high because of various components found in the waste. In general, MSW is an inferior fuel to landfill gas, which has become the preferred method of burning waste methane. Refuse derived fuel may be cleaner and offer better combustibility than MSW, but new gasification systems being developed would outperform the fuel in its solid form.

\subsubsection{Environmental Issues}

Although not renewable in the traditional sense of the word, it could be argued that municipal solid waste is a partially renewable energy source, since trash is always being created and has a high biomass concentration. However, new Boiler MACT legislation will likely classify MSW as a solid waste rather than a fuel, making emission regulations extremely strict. Incinerating MSW reduces the amount of waste by up to 90 percent in volume and 75 percent in weight, but there are many pollutants released in the process. ${ }^{53}$ Scrubbers, catalytic reduction, and other pollution control technologies can reduce the toxic materials that are emitted.

\subsubsection{Availability, Cost, and Installed Capacity Data}

Availability: Over 200 million tons of municipal solid waste is produced each year in the United States alone. ${ }^{54}$ Municipal solid waste is available at any of the thousands of landfills located in the U.S., but it is

\footnotetext{
${ }^{52}$ U.S. Energy Information Administration Form EIA-860 Database Annual Electric Generator Report, 2008.

${ }^{53}$ Liscinsky, David. Biomass Gasification and Power Generation Using Advanced Gas Turbine Systems, Final Report October 2002. United Technologies Research Center. October 2002.

${ }^{54}$ Ibid.
} 
rarely used as a fuel. Landfill gas utilization is usually a more attractive option, but for many landfills this is not a possibility, and MSW is a viable option

Costs: MSW is a no-cost fuel source, but collecting, drying, and transporting the waste can be fairly expensive. In addition, major equipment modifications and emission control technologies will likely be required.

Installed Capacity (Non-Utility): MSW accounted for 2.7 GW of electric capacity in 2012, a figure that has remained unchanged for five years. ${ }^{55}$

\subsubsection{The Bottom Line}

Municipal solid waste is not an ideal opportunity fuel, for a number of reasons. Its quality varies, it is not easily transported, it needs to be sorted and dried, and emission control technologies must be implemented. MSW and RDF are not recommended as solid fuels, unless at dedicated waste to energy facilities that are designed to handle the complexities of using these fuels and treating their emissions.

\subsubsection{Sludge Waste}

Sludge waste is the sludge generated by wastewater treatment plants or by industrial processes such as paper mills. The sludge can be dried and burned as a fuel to generate steam and power. In the case of wastewater sludge, it is often converted into anaerobic digester gas for solids reduction and fuel use. Burning the solid sludge, however, is another power-producing alternative that takes advantage of its heat content.

For solid-firing, the sludge must be dried or dewatered thoroughly (to over 55 percent dry content) prior to combustion. Once this occurs, it can be used in existing boilers in place of coal. Some modifications to existing boilers may be necessary to accommodate the low combustibility of the fuel and increased cleaning and maintenance will be required. Limited percentages of sludge can be cofired with coal with no modifications required, but this report is only considering applications that can use 100 percent opportunity fuels. Stokers are preferred for firing the sludge waste since fewer modifications are necessary.

\subsubsection{Current Status}

Not many wastewater treatment plants use their sludge to generate electricity, but the technology exists and solid sludge waste can be used as a source of power. Sludge drying for fuel use is much more common in Europe. ${ }^{56}$ It is generally more effective to use an anaerobic digester to convert the organic portion of the waste to a more flexible, gaseous fuel, due to the high moisture content of sludge waste.

\footnotetext{
${ }^{55}$ U.S. Energy Information Administration Form EIA-860 Database Annual Electric Generator Report, 2008-2012.

${ }^{56}$ CH2M Hill, Technical Memorandum to Western Wake Project Partners, Evaluation of Sludge Dryer and Dewatering Facilities, March 2008.
} 
There are some facilities that use paper sludge to produce steam and power, but this practice is generally limited to paper mills.

\subsubsection{Economics and Market Considerations}

The heat content of sludge waste is only about 3,500 Btu/lb (25-30 percent that of coal), its moisture content is very high, and sludge-fired boilers require additional maintenance. As a result, sludge waste is not a strong potential energy source for outside markets. However, it is a free source of fuel that can be used by wastewater treatment plants in combined heat and power applications. Heat content can be boosted to 7,000 Btu/lb with drying, but this is very capital-intensive. ${ }^{57}$ If excess power is produced, it may be sold to local utilities or consumers. However, for wastewater treatment plants that already utilize anaerobic digesters, ADG is almost invariably a cleaner, more efficient, and smarter choice for CHP.

\subsubsection{Environmental Issues}

The use of sludge waste as a fuel promotes conservation of resources and disposes of potentially hazardous wastewater sludge, but burning the waste creates its own emissions such as NOx and particulate matter, which must be handled properly with emission control technologies. Using an anaerobic digester to extract the methane from organic sludge waste and burning the digester gas as a fuel is generally seen as a more environment-friendly option.

\subsubsection{Availability, Cost, and Installed Capacity Data}

Availability: There are over 75,000 wastewater treatment plants in the United States. Sludge waste is treated in some way at every one of these plants, but it is rarely used as a direct energy source due to its poor combustibility and low fuel quality. In addition, there are many paper mills that may produce excess sludge waste that could be available.

Costs: The sludge waste is free to treatment plants, except for the costs associated with collection, drying, and transportation. Wastewater sludge is not generally sold as a fuel - when it is used, it is only by the plants themselves

Installed Capacity (Non-Utility): Sludge waste accounted for 6.5 MW of electricity in the year 2008, but in 2012, there were no installations with sludge waste as the primary energy source. ${ }^{58}$

\subsubsection{The Bottom Line}

Sludge waste is not an ideal fuel for power generation. It can be useful to waste water treatment plants, paper mills, or other nearby plants that need steam and/or power, but its utility as a marketable boiler fuel

\footnotetext{
${ }^{57}$ Ibid.

${ }^{58}$ U.S. Energy Information Administration Form EIA-860 Database Annual Electric Generator Report, 2008-2012.
} 
is questionable. For wastewater treatment plants, anaerobic digester gas is generally a more favorable option, except for some treatment facilities with boilers where no digester is installed.

\subsubsection{Wood Waste}

Wood waste can be found at lumber mills and wood processing facilities as a residue (bark, sawdust and planer shavings), as well as in urban wood waste streams (construction debris, yard trimmings, etc.). Industrial facilities that produce wood waste and mill residues tend to utilize these fuels on-site in woodfired boilers. However, urban wood waste is often collected at wood recycling yards like the one pictured in Figure 11, and it can be processed and sold for a relatively low price. Large amounts of urban wood waste are produced in metropolitan areas with high population densities - the higher the population, the more wood waste is produced.

In most wood waste applications, the material is dried, cut into chips, and transported to a boiler, producing steam and sometimes powering a steam turbine generator. Wood cofiring is sometimes used to increase the net heat rate of a coal power plant, but its effectiveness is limited due to wood's poor grindability. Pulverizers for coal are unable to handle high quantities of wood, so pulverized coal boilers are generally not used. Stokers are ideally suited for co-firing wood and wood waste fuels as they require the least modifications. However, fluidized bed boilers have been increasingly used with wood fuels because they can flexibly utilize several different fuel types, and they are designed to produce fewer emissions.

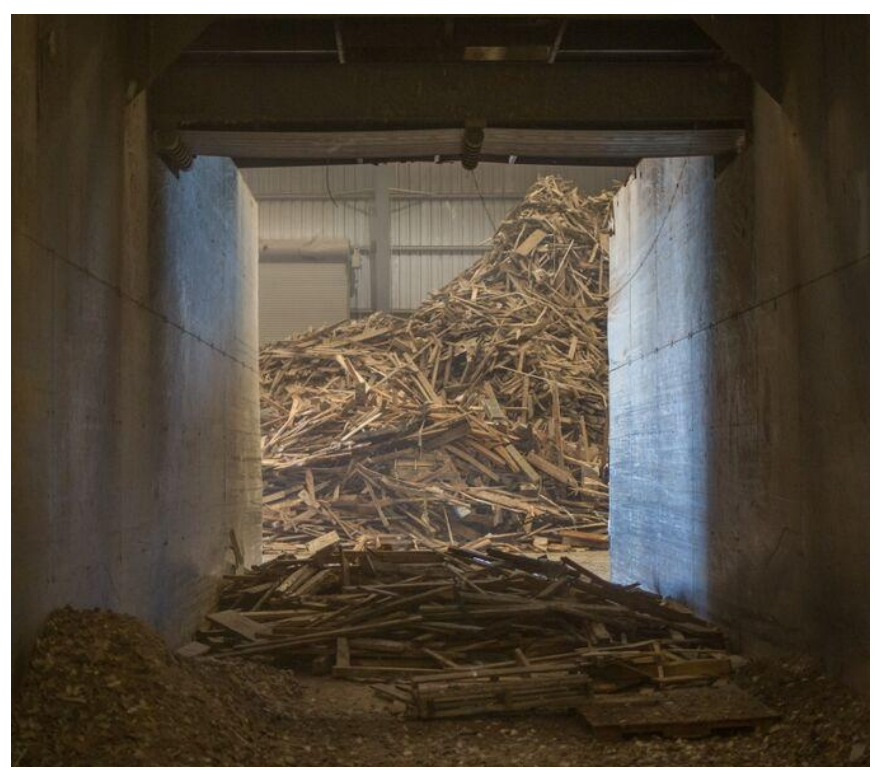

Figure 11. Sorting of Wood Waste

(Source: www.wmra.org)

\subsubsection{Current Status}

There are 179 wood-fueled steam turbine generators in the country, ranging from less than $1 \mathrm{MW}$ to over $50 \mathrm{MW}$, providing over $3 \mathrm{GW}$ of electric capacity. ${ }^{59}$ Many of these are utility power generators, but most are industrial facilities utilizing their wood waste for on-site heat and power needs. Even more facilities utilize their wood waste strictly for steam generation and process heating applications. Although urban wood waste is available in many locations as a potential fuel, it has not yet been adopted by many industrial facilities, with the exception of some coal cofiring applications. The amount of wood waste power generation could be significantly increased with more industrial boilers in high population-density areas with substantial urban wood waste resources.

\footnotetext{
${ }^{59}$ Ibid.
} 


\subsubsection{Economics and Market Considerations}

The majority of wood-based power production currently takes place in on-site cogeneration applications, using wood waste and mill residues from lumber processing, wood manufacturing, and pulp and paper operations. These industries have a very low-cost fuel source, requiring no transportation, with the ability to meet on-site thermal and electric power demands. Like black liquor, the mill residues produced by these industries are almost always used to provide additional heat and power for their plants. For this reason, the market for mill residues is relatively small, and it will not be further considered as a fuel source in this report.

For industrial facilities located near highly-populated areas, urban wood waste can be a high-supply, lowcost fuel source for steam and power generation. According to a study by the Renewable Energy Policy Project, the collection cost for urban wood waste works out to about \$1 per MMBtu as a rule of thumb, so it can be very competitive with coal and other fuels even with high transportation costs. ${ }^{60}$ For industrial sites located close to urban wood waste collection or recycling centers, a biomass boiler can be used to produce large quantities of steam with low-cost urban wood waste, while a back-pressure steam turbine generator could provide a pressure-drop for plant steam while on-site electricity is generated. The availability and economics of urban wood waste CHP installations will be further explored later in this report.

\subsubsection{Environmental Issues}

Like forest residues, sources of wood waste are generally considered to be renewable resources. Although carbon dioxide is produced in burning wood fuels, with the growth of new trees, the net carbon dioxide emissions will approach zero. Urban wood waste may contain components and pollutants that need to be removed prior to burning, or else hazardous emissions and increased fouling will occur. $\mathrm{SO}_{\mathrm{x}}$ and $\mathrm{NO}_{\mathrm{x}}$ emissions are much less than coal so co-firing will help reduce emissions. Wood ash is nontoxic and does not contain pollutants or heavy metals, but some states still consider it hazardous waste.

\subsubsection{Availability, Cost, and Installed Capacity Data}

Availability: There is an abundance of urban wood waste suitable for use as a fuel, with an estimated 31 million dry tons available annually. ${ }^{61}$

Costs: Collection costs for urban wood waste are estimated at \$1/MMBtu, with transportation costs adding about 40 cents per ton-mile.

Installed Capacity (Non-Utility): Solid wood waste: 3.9 GW of electric capacity in $2012 .^{62}$

\footnotetext{
${ }^{60}$ Costs of Bioenergy. Renewable Energy Policy Project \& Center for Renewable Energy and Sustainable Technology. http://www.repp.org/bioenergy/link5.htm. May 2011.

${ }^{61}$ Milbrandt, A. A Geographic Perspective on the Current Biomass Resource Availability in the United States. United States Department of Energy, National Renewable Energy Laboratory. Technical Report. December 2005.

${ }^{62}$ U.S. Energy Information Administration Form EIA-860 Database Annual Electric Generator Report, 2012.
} 


\subsubsection{The Bottom Line}

Wood and wood waste are promising biomass-based opportunity fuels. Although the cost for these fuels is usually greater than coal, they burn cleaner and can easily be co-fired. While solid wood fuels are best suited for industrial applications, they can also be a fuel source for steam-powered CHP, especially coalfired units in the 5-50 MW range.

\subsection{INDUSTRIAL PROCESS WASTE AND BYPRODUCTS}

The second category of opportunity fuels, Industrial Process Waste and Byproducts, consists of nonbiomass fuels created as a waste or byproduct of an industrial process. Blast furnace gas, coke oven gas, petroleum coke, refinery fuel gas, industrial VOCs, and textile waste all fall into this category. All of these opportunity fuels are produced at industrial facilities, and would otherwise be considered a waste or byproduct (although many may already be used by the facilities for additional heat and/or power).

Blast furnace gas, petroleum coke, refinery fuel gas and coke oven gas are produced at steel mills or petroleum refineries. The gaseous fuels are often recirculated for additional heat, but many facilities could potentially see more benefits from a CHP installation. Petroleum coke is a solid fuel with high energy density produced in large quantities at petroleum refineries. However, currently more pet coke is sold to overseas markets than domestic markets. Textile waste and industrial VOCs are not used extensively by the facilities that produce them, with the exception of some textile waste being cofired in coal boilers.

In this section, the industrial waste and byproduct fuels will be examined to see if there is any potential for CHP. If so, the fuels may be chosen for further evaluation in this report.

\subsubsection{Blast Furnace Gas}

Blast furnace gas (BFG) is the gas exhausted from blast furnaces in iron and steel mills. The gas can be sent to a coke oven for additional heat, recirculated to supply heat to the furnace, or it may be used to produce heat and power. BFG gas has a high carbon content, an extremely low heating value, and variable quality. The gas can be burned in a boiler, and exhibits properties similar to natural gas, but its quality and heat content (typically around $100 \mathrm{Btu} / \mathrm{ft}^{3}$ ) are abysmally low. Blast furnace gas deposits adhere very firmly to boiler surfaces so special provisions and extra effort must be made when cleaning the boiler. The blast furnace gas supply is prone to sudden fluctuations, so special safety precautions are required and an alternative fuel must be available if steam or electricity production is to be steadily maintained. Because of all of these drawbacks, BFG is rarely burned as a fuel - it is most often recirculated in the furnace or coke oven for additional heat.

\subsubsection{Current Status}

Currently, blast furnace gas is only utilized in the iron and steel mills where blast furnaces are used. Its low heating value seriously limits its effectiveness and potential as a fuel. There are no conceivable 
opportunities to market blast furnace gas to other industrial sites, but it could potentially be utilized for power production in addition to providing heat for steel mills.

\subsubsection{Economics and Market Considerations}

Blast furnace gas could be transported and sold to nearby facilities for heat and power operations, but there is neither an abundant supply of the gas nor a foreseeable demand. It is an inferior fuel to natural gas in terms of heat content, particulates, and emissions, and it is best utilized immediately after collection while it is still at a high temperature. It is more economically feasible for steel mills to use BFG for their own heat and power needs than to sell it to an outside power producer.

The market for blast furnace gas is limited to iron and steel mills. Most mills that produce the gas already use it for recirculation and additional heat. Some mills use the gas as additional fuel for their boiler systems, sometimes powering steam turbines for electricity. New steel making technologies, however, may soon render the blast furnace obsolete, and there is already a downward trend in production and demand for BFG.

\subsubsection{Environmental Issues}

Blast furnace gas has a high carbon content, and an extremely high nitrogen content. When burned, large amounts of carbon dioxide and nitrogen oxides will be produced, and emission control technologies must be applied.

\subsubsection{Availability, Cost, and Installed Capacity Data}

Availability: Availability is determined by the usage of blast furnaces, primarily in iron and steel mills. Almost all blast furnace gas is recirculated or used in some other way by the mill itself, so the gas is generally unavailable for outside purchase.

Costs: BFG is free to iron and steel mills. Its quality is too low to be sold to outside markets.

Installed Capacity (Non-Utility): Blast furnace gas accounted for an estimated $1.3 \mathrm{GW}$ of electric capacity and 94.5 million MMBtu of thermal output in the year 2000, the high thermal to electric ratio indicating that the fuel is almost always used for heat. ${ }^{63}$ By the year 2008, BFG's electric capacity decreased to 994 MW, and it stands at $930 \mathrm{MW}$ in 2012. ${ }^{64}$

\subsubsection{The Bottom Line}

Blast furnace gas has several disadvantages as an opportunity fuel. Production of BFG is on the decline and quality of the fuel is extremely low. It is beneficial to the iron and steel mills that produce it, but its utility in DG/CHP applications is limited.

${ }^{63}$ U.S. Energy Information Administration Form 860 B - Database of Non-Utility Generators, 2000.

${ }^{64}$ U.S. Energy Information Administration Form EIA-860 Database Annual Electric Generator Report, 2008-2012. 


\subsubsection{Coke Oven Gas}

Coke oven gas refers to the exhaust gas generated when coal is transformed into carbonaceous coke in high-temperature coke ovens. The coke is then blended with iron in blast furnaces at steel mills. The gas can be collected, cleaned, and used as a fuel, although the quality is not nearly as high as natural gas (coke oven gas is only about 35 percent methane and almost 50 percent hydrogen). Coke oven gas burns readily because of its high free-hydrogen content, which also makes it an ideal candidate for fuel cells. Its heating value is around $500 \mathrm{Btu} / \mathrm{ft}^{3}$ (about half that of natural gas) so most natural gas gensets will require some modifications and additional maintenance to accommodate the lower methane content. The fuel can be used in place of natural gas in boilers, but larger burner-gas port openings may be required due to the higher flow rate, impurities, and resulting deposit build-up. Coke oven gas can also be used to power modified engines and gas turbines, but the fuel's variable supply and low methane content limit its energy producing capabilities.

\subsubsection{Current Status}

Coke oven gas is currently used only at steel mills and merchant coke plants, typically for heat recirculation and on-site process heating applications. It is not produced in great quantities, and it supply is tied to domestic steel production. Its inferiority to natural gas and its limited availability prevent coke oven gas from being a serious contender in outside markets.

\subsubsection{Economics and Market Considerations}

At steel mills and merchant coke plants, using coke oven gas to produce heat or electricity can be a good economic decision. The gas could also be sold to nearby power producers, transported through a pipeline and sold for roughly the same price as natural gas. However, pipeline construction costs can be high, and it is generally more beneficial for a plant to use coke oven gas for its own power needs. Most mills that produce coke oven gas already burn it as a fuel or recirculate it for additional heat, so the remaining market for coke oven gas is limited merchant coke plants that may not currently benefit from its utilization.

\subsubsection{Environmental Issues}

The cokemaking process creates some environmental concerns. Air emissions and the use of quench water cause major environmental problems in the just the manufacturing process. Harmful sulfur and nitrous oxide emissions, as well as particulates, are also produced when burning coke oven gas for energy. Control technologies must be applied in both cases, and they can be costly. 


\subsubsection{Availability, Cost, and Installed Capacity Data}

Availability: Unknown. Coke oven gas is not sold as a fuel - it is only used by steel mills and coke plants that produce it.

Costs: Coke oven gas is a low-cost fuel source, but gas cleanup requirements can be expensive to implement depending on the application. For CHP, extensive cleaning would be necessary.

Installed Capacity (Non-Utility): The installed electric capacity of coke oven gas is unknown, although 1.3 GW of electric capacity existed in 2012 for an "other gas" category which includes coke oven gas. ${ }^{65}$

\subsubsection{The Bottom Line}

Coke oven gas generally is not a practical fuel for outside markets since its quality is significantly lower than natural gas and its supply depends on the use of coal and petroleum. For facilities that have a nocost gas supply, however, it can be a practical and cost-effective source of heat and power. As with black liquor, most of the mills and refineries that can make use of their coke oven gas already do so, so the market that is leftover for CHP is relatively small.

\subsubsection{Industrial VOCs}

Volatile organic compounds (VOCs) evaporate easily during many industrial processes, and they are an ever-increasing threat to the environment. Industrial VOCs must be collected and eliminated from the atmosphere. This is usually accomplished through oxidation, using thermal or catalytic oxidizers. However, the VOCs can instead be used as a fuel to help supply power for the industrial operation, while at the same time eliminating environmental threats.

Thus far, the only technology that has been successfully applied to industrial VOCs is cofiring in a natural gas combustion turbine. High-temperature combustion is preferred in order to eliminate all of the dangerous compounds, and this can only be achieved with a secondary fuel. In addition, the VOC-air mixture is simply too dilute to be used on its own. The VOC fuel is treated like an air injection into the gas combustor, and it is essentially just that, since the concentration of VOCs is so low. However, the highly reactive VOCs will provide additional energy to the natural gas stream as it enters the turbine, which can be used as a CHP unit to power the entire facility.

\subsubsection{Current Status}

Currently, the use of industrial VOCs is limited to cofiring with natural gas turbines. Advanced in gas turbine technology that increase efficiency and reduce energy costs will help bolster utilization of this technology. Stirling Engines may be another outlet for VOCs as a fuel - in a recent demonstration project, STM Power installed a $55 \mathrm{~kW}$ Stirling Engine at a Ford Motor Company plant that runs on paint VOCs. However, Stirling Engines are only entering the first stages of commercialization.

${ }^{65}$ U.S. Energy Information Administration Form EIA-860 Database Annual Electric Generator Report, 2012. 


\subsubsection{Economics and Market Considerations}

While the fuel efficiency of the gas turbine is enhanced by a limited amount of VOC-air injection, the concentration of VOCs is so low that there is no noticeable degradation in performance, and no additional maintenance is required. The market for industrial VOCs as a fuel is limited to industrial plants that produces the volatile compounds. Many of these plants already use oxidizers to eliminate their VOCs, and are unlikely to abandon them and switch to this gas turbine technology, unless a significant decrease in operating costs is incurred. The main market for the fuel is new or expanding industrial facilities, or plants located in areas with increasingly strict emissions regulations. As with most CHP projects, the market also depends on the local price of electricity and natural gas. Areas with high electricity prices are more likely to benefit from distributed power, though in the case of VOCs, high natural gas prices have a negative effect on the market for industrial VOCs, since they must be cofired with the fuel.

\subsubsection{Environmental Issues}

The elimination of volatile organic compounds from the atmosphere is positive for the environment. However, some VOCs may survive the combustion process and be emitted into the atmosphere. To prevent this, a high-temperature but long-residence time combustion process is preferred, and this is possible when using a natural gas combustion turbine.

\subsubsection{Availability, Cost, and Installed Capacity Data}

Availability: Industrial VOCs are produced in many industrial facilities throughout the country. Most of these facilities already have oxidizers in place to cut down on VOC emissions, but they still may benefit from VOC utilization and on-site power generation. The exact availability numbers are unknown.

Costs: Industrial VOCs are free to industrial plants, and the facility must treat these wastes properly. Thus, the cost of using VOCs for fuel can be equated to the cost of the competing treatment option. The cost to install a natural gas turbine and the necessary VOC collection and transportation equipment at a facility is only slightly higher than a normal gas turbine, and the maintenance required is about the same.

Installed Capacity: Unknown, and difficult to measure since most of the power comes from natural gas.

\subsubsection{The Bottom Line}

Using industrial VOCs to produce power is an innovative and efficient way of eliminating VOCs from the air while producing heat and electricity for an industrial plant. However, the fuel's use is limited to VOCladen air injection into a natural gas combustion stream. Most of the energy produced by the turbine comes from the natural gas, not from the dilute VOC-air mixture. While this practice is certainly worthy of consideration as a competitive treatment option, industrial VOCs do not currently qualify as a standalone fuel. 


\subsubsection{Petroleum Coke}

Petroleum coke (pet coke), a carbon-rich black solid, is the byproduct of coking conversion processes, which separate light and heavy crude oil products. Pet coke is in abundant supply and its price is always less than that of coal. There are three types of pet coke produced in the coking process - sponge, shot, and needle. Only sponge and shot coke are used as a fuel. Some drawbacks of petroleum coke include a low volatility, a high sulfur content, and high nickel and vanadium contents in the ash. However, the fuel offers a high heat content (14,000 Btu/lb), a low ash content and easy grindability at a very low cost.

Petroleum coke can be used in place of coal or fuel oil in conventional boilers, with some modifications. However, the fuel is heavy in particulates and has a high sulfur content, so extensive emission controls could be required. For this reason, pet coke is often blended and co-fired in small percentages with subbituminous coal in large-scale industrial applications. Power producers sometimes utilize 100 percent pet coke in large-scale power plant boilers, but the majority of pet coke produced in the United States is currently exported to foreign markets.

\subsubsection{Current Status}

The United States production of petroleum coke in 2010 was equivalent to 263 million barrels of oil. The majority (164 million barrels of oil equivalent in 2010) of this pet coke is exported to foreign markets, where it is used as an industrial fuel. ${ }^{66}$ Exports have increased steadily over the past decade, along with the growth of the Chinese economy. In 2005, 42 percent of the total pet coke supply was exported, while in 2010, 55 percent of all U.S.-produced petroleum coke was exported. ${ }^{67}$ During this time, Chinese markets have been willing to pay significantly more for petroleum coke than U.S. markets, but this could change as China's economic growth diminishes.

Pet coke has a low combustibility compared to coal, so mixing the fuels can create difficulties, but small percentages of pet coke can be blended with coal and other fuels in stokers and fluidized bed boilers. In the United States, the Department of Energy (DOE) estimates that the largest users of pet coke (other than refineries) are independent power producers, who typically fire 100 percent coke, not a coke-coal blend, in boiler/steam turbine systems over $50 \mathrm{MW}$ in size.

\subsubsection{Economics and Market Considerations}

Petroleum coke production increased rapidly in the 1990s along with the worldwide demand for light crude oil products (for which petroleum coke is the by-product). During this time, the large and growing supply of petroleum coke provided an inexpensive, plentiful fuel source for emerging Asian markets. Pet coke production has recently steadied, but the overseas demand for the inexpensive fuel has risen, and coastal and off-shore refineries in the Gulf states and West Coast continue to export large amounts of the fuel. Customers are generally not willing to purchase pet coke if they can obtain coal for the same price, which bodes well for overseas demand, but not domestic demand, as American coal prices are relatively low while availability remains high. Industrial sites located close to oil refineries could potentially

\footnotetext{
${ }^{66}$ United States Energy Information Administration, Petroleum Coke Supply and Disposition Data, 2010.

${ }^{67}$ Ibid.
} 
purchase pet coke at a lower price than coal, but the domestic market for industrial pet coke power production is fairly limited.

Very few mills and refineries market petroleum coke themselves. Leftover pet coke is contracted out to resellers by refineries for market distribution. In the United States, large independent power producers and refineries are the main users of pet coke - utilities only use it sparingly as an alternative boiler fuel. The vast majority of petroleum coke in the United States is either sold to overseas markets or utilized domestically, with leftover stocks of pet coke remaining steady at around 9,000 barrels of oil (equivalent) for several years.

Worldwide, petroleum coke is most often used in cement kilns and calcining operations. The best markets for pet coke are places where coal is not readily available and/or more expensive, including Japan and certain areas in China. In order for pet coke to be sold to new domestic users, overseas markets must be outbid, and they will generally pay up to $\$ 50 /$ ton for the fuel.

\subsubsection{Environmental Issues}

Petroleum coke typically has a very high sulfur content (up to 8 percent), which causes significant sulfur oxide emissions. Therefore, pet coke is not a good choice for areas with stringent $\mathrm{SO}_{\mathrm{x}}$ emission standards. The nitrogen content of pet coke is also higher than coal. This, along with higher required flame temperatures, leads to increased $\mathrm{NO}_{\mathrm{x}}$ emissions. The ash of petroleum coke contains high nickel and vanadium contents, and it is prone to produce more dust than most coals. Pet coke boilers require more emission controls than coal-fired boilers, as well as more frequent cleaning and maintenance.

\subsubsection{Availability, Cost, and Installed Capacity Data}

Availability: The availability of pet coke depends on the production of light petroleum products. The United States produced the equivalent of 263 million barrels of oil in pet coke in 2010, with over 60 percent being exported to foreign markets, and most of the rest being utilized domestically. ${ }^{68}$

Costs: Petroleum coke is typically sold to overseas markets for $\$ 40-\$ 50 /$ ton, so coal is a less expensive option for most potential domestic users.

Installed Capacity (Non-Utility): Petroleum coke accounted for 2.7 GW of electric capacity in the year 2012, up from $1.7 \mathrm{GW}$ in 2008. ${ }^{69}$

\subsubsection{The Bottom Line}

Petroleum coke is a relatively inexpensive energy source that is produced in large quantities. However, it contains many contaminants and pet coke boilers may require more emission controls than coal boilers. In addition, the available supply of petroleum coke for CHP installations is questionable, as domestic

\footnotetext{
${ }^{68}$ Ibid.

${ }^{69}$ U.S. Energy Information Administration Form EIA-860 Database Annual Electric Generator Report, 2008.
} 
supply, overseas markets, and domestic demand seem to have found a balance over the past several years as U.S. installations have increased, with year-end stocks remaining steady and relatively low.

\subsubsection{Refinery Fuel Gas}

Refinery fuel gas, or still gas, is produced during the petroleum refining processes that separate light and heavy crude oil. Its consistency is similar to coke oven gas, although it tends to have a high sulfur content. The oil refineries that produce this gas often utilize it for on-site heating demands, but it is generally not used for electricity generation.

\subsubsection{Current Status}

Refinery fuel gas is currently produced in large quantities at oil refineries across the country. Most of these refineries are located in the Gulf Coast region. All refineries utilize the majority of the fuel gas that they produce, generally using it to its maximum onsite capability. However, it is currently not used for electricity generation, and a large amount of refinery fuel gas is flared by sites (see Figure 12), because on-site demand is limited compared to the quantity of gas produced. This gas could potentially be cleaned and transported to nearby industrial sites via pipeline, where it could be used in CHP applications. However, excess fuel gas is only flared sporadically during operational upsets and power outages, so it could be difficult to obtain a steady stream of refinery fuel gas without cutting into a refinery's current utilization practices.

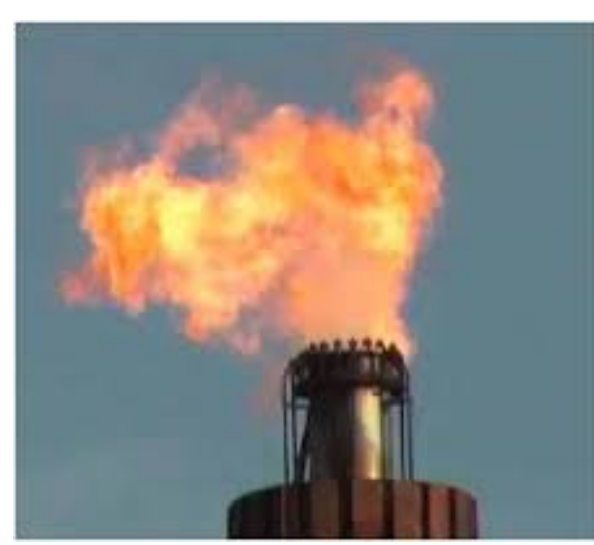

Figure 12. Fuel Gas Flare at an Oil Refinery

(Source: www.epa.gov)

\subsubsection{Economics and Market Considerations}

In general, refinery fuel gas is not seen as a high-value product to oil refineries, as the cost and effort to clean and transport the gas would likely outweigh the price that nearby facilities are willing to pay for the fuel. Therefore, the gas is utilized to its maximum potential on-site, and the remaining gas is usually flared by the refineries. While pipelines could be constructed to nearby sites, the excess flared gas is produced intermittently, so gas storage equipment would be required to generate a steady stream for the industrial site. Pipeline construction is an expensive process, and gas storage equipment can become extremely costly when high volumes are required. In order to utilize refinery fuel gas effectively for CHP, industrial facilities would require access to gas that is normally utilized by the refineries, since the excess gas is not a steady or reliable fuel source. Because refineries would have to replace their lowvalue fuel gas with high-value natural gas, industrial sites would need to provide considerable compensation. 


\subsubsection{Environmental Issues}

The utilization of refinery fuel gas is generally better for the environment than flaring the waste gas, but there are some potentially harmful emissions that could require treatment. In addition to the potential threat of $\mathrm{NO}_{\mathrm{x}}$ formation, refinery fuel gas is typically high in sulfur and hydrogen sulfide, so $\mathrm{SO}_{2}$ emissions can be an issue. EPA regulations dictate allowable sulfur concentrations for refinery fuel gas combustion and utilization, so gas scrubbing is typically required prior to use. Post combustion controls for $\mathrm{NO}_{\mathrm{x}}$ also may be required in non-attainment areas.

\subsubsection{Availability, Cost, and Installed Capacity Data}

Availability: Most refinery fuel gas is utilized on-site at oil refineries, but large amounts of the gas are often flared. It is uncertain how much gas would be available for CHP.

Costs: Refinery fuel gas is a no-cost fuel source to oil refineries, but the gas must be cleaned and transported via pipeline to be used in off-site CHP applications. Gas treatment equipment and pipeline costs could be prohibitive.

Installed Capacity: There are no known facilities utilizing refinery fuel gas for CHP.

\subsubsection{The Bottom Line}

Refinery fuel gas is not a very promising fuel for CHP installations. While it is a no-cost fuel source for oil refineries, excess fuel gas is produced intermittently, and the potential for utilizing refinery fuel gas in CHP applications at these sites is limited. The cost to clean and transport the gas to a nearby site would likely outweigh the potential benefits.

\subsubsection{Textile Waste}

Textile waste can consist of excess yarn, thread, cloth, carpet, or any other fabric. The excess material is either recycled or thrown away as garbage. However, the waste can be utilized as an energy source with about the same heat content as biomass. Although the waste contains many more pollutants and contaminants than biomass fuels, it can still be cofired with coal to produce heat and power for textile mills.

Although gasification systems exist for textile waste (to be cofired with natural gas instead of coal), these systems' high capital cost-to-benefit ratio make them impractical for most textile mills. The fuel's quality is generally too low to be fired by itself, so cofiring with coal is the only practical option. Most coal-fired boilers can handle a 5-10 percent blend of textile waste with little, if any, modifications required. 


\subsubsection{Current Status}

Currently, most textile waste is recycled, although some textile mills utilize their waste in cofiring applications to produce their own heat and power. The quality of textile waste as a fuel is extremely poor compared to coal, so cofiring is usually the only feasible option.

\subsubsection{Economics and Market Considerations}

For most textile mills, the benefit of utilizing their waste comes from saving on coal costs. Usually, textile waste is only a practical fuel for mills that already contain a coal-fired boiler. However, in cases where on-site power generation could seriously reduce electricity costs (i.e. locations where the cost of electricity is high), installing a coal-fired boiler and using textile waste as a blended fuel is an option.

The market for textile waste as a fuel is generally limited to textile mills, due to its low value, and even then it is limited to coal cofiring applications. Mills already using coal-fired boilers are the best potential market. At present there is no other identifiable place in the CHP market for textile waste as a fuel.

\subsubsection{Environmental Concerns}

Although textile wastes contain some harmful constituents, burning a 5 to 10 percent blend will not contribute significantly to regulated emissions. Typically, the same emission controls for coal-fired boilers will also apply to coal-textile waste blends.

\subsubsection{Availability, Cost, and Installed Capacity Data}

Availability: Textile waste is available at every textile mill, although not all mills will benefit from its utilization - most are better off recycling their waste.

Costs: For a plant that already contains a coal-fired boiler, adding textile waste to form a 5-10 percent blend is usually beneficial. Few, if any, modifications are necessary, and the plant will save on fuel costs. For plants without a coal-fired boiler, a cost-benefit analysis must be performed.

Installed Capacity: Unavailable. Installed capacity is minimal.

\subsubsection{The Bottom Line}

Textile waste is not promising as an opportunity fuel. Its heating value is lower than biomass, it contains more pollutants, and it must be cofired with coal to be effective. Furthermore, the market for textile waste as a fuel is generally limited to textile mills. 


\subsection{FOSSIL FUEL DERIVATIVES}

The third category of opportunity fuels are fossil fuel derivatives. These fuels are derived from fossil fuel mining and drilling operations, where excess gas is created and must be treated and disposed of. Most mines and wells flare their excess gas to prevent the release of methane into the atmosphere. This gas, however, can often be used for power production in CHP applications.

At coalmines, the mining process produces a methane gas whose properties and heat content are very similar to natural gas. The gas is called coalbed methane, and it is typically cleaned and injected into natural gas pipelines, but it can also be used as a fuel for CHP projects.

At oil and gas wells, excess gas escapes to the top of the well, building up pressure. In order to release this pressure, the wells release and flare the untreated gas. However, this wellhead gas can be used for small-scale power generation at the oil and gas wells' facilities.

This section examines these two fuels derived from fossil fuels, and determines if there is enough potential for CHP to warrant further evaluation in the chapters to come.

\subsubsection{Coalbed Methane}

Coalbed methane (CBM) is a methane gas that is released from coalmines. It can be collected before, during, and after mining, and condensed into a fuel similar to natural gas. The highest quality gas comes from drainage holes made before mining. In this situation, methane has not had a chance to interact with air. CBM can also be collected from coalmine ventilation air, but the quality and percentage of methane is much lower. After mining, high quality CBM can be collected from gob wells. See Figure 13 for a diagram of a typical coal mining operation.

Coalbed methane can replace natural gas in any power generating technology, including gas turbines, steam turbines, microturbines, reciprocating engines, and fuel cells. The gas collected from drainage holes before and after mining is usually around 90 percent methane, so it can be used in natural gas applications with no degradation in quality. In fact, drainage methane is so similar to natural gas and so and high in quality that is often injected directly into natural gas pipelines. Ventilation air emissions, which account for the majority of coalmine methane emissions, are low quality methane-air mixtures. New technologies, however, can oxidize the ventilation air to make it suitable for thermal energy applications. The

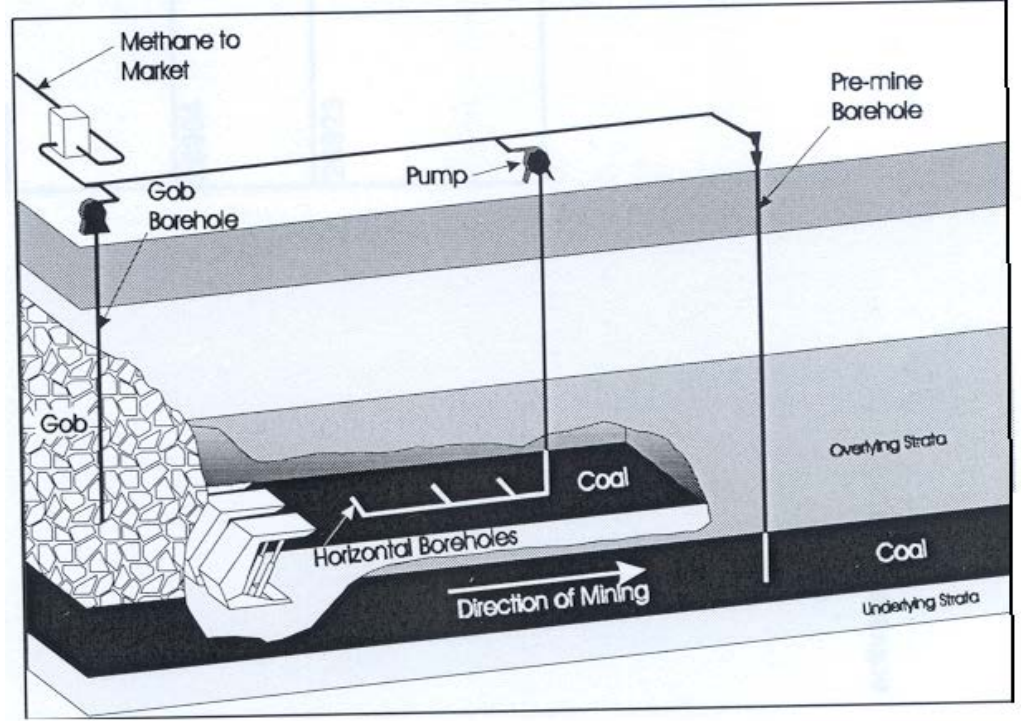

Figure 13 Coalbed Methane Collection Process - CBM can be collected before, during and after mining Source: EPA CMOP website http://www.epa.gov/cmop/pdf/inf002.pdf 
thermal demand at coalmines is limited, so on-site combined heat and power operations are rare.

\subsubsection{Current Status}

In 2006, over 45 billion cubic feet of coalbed methane was recovered and utilized, compared to about 8 billion cubic feet emitted from drainage. The vast majority of recovered coalbed methane was injected into natural gas pipelines. ${ }^{70}$ The Coalbed Methane Outreach Program (CMOP) is an EPA program encouraging the use of coalbed methane as an energy source. In addition to providing resources and promoting the use of CBM, the program helps plan and finance CBM projects.

Currently, the most common application for CBM is pipeline sales, where the gas is cleaned and injected directly into natural gas pipelines. Currently, about 10 percent of all natural gas in United States pipelines was originally coalbed methane. ${ }^{71}$ The National Petroleum Council is considering utilizing coalbed methane even further, to make it a more significant source of domestic natural gas. With their 2003 report, Balancing Natural Gas Policy: Fueling the Demands of a Growing Economy, the Council showed interest in obtaining CBM from coal reserves, specifically those located beneath the Rocky Mountains. Most of these reserves are not being mined, and are currently inaccessible, but there is still great potential for future use. However, the utilization of these reserves for natural gas should not have any significant impact on the potential for coalbed methane CHP

\subsubsection{Economics and Market Considerations}

Coalbed methane can be used in many ways to produce revenue. Drainage methane is usually of high enough quality to be injected into natural gas pipelines or used in natural gas units without any modifications to existing equipment. Many smaller mines do not currently have drainage systems installed, although the cost to install a drainage system is not very high considering the many benefits that can be obtained from the high quality gas. Methane from ventilation air, which accounts for most of the methane emissions from coalmines, is a mixture so its quality is not nearly as high. Even so, the ventilation air, which is normally flared, can be used to provide thermal energy at the coalmines, since their thermal demand is typically low.

The process of collecting methane from the mine, both drainage or ventilation air, is not expensive and most of the necessary steps (i.e. the drainage holes and collection devices) are already set in place. The gas only needs to be stored and transported to a CHP unit for power production. The main issue then, is the coalmine's demand for electricity and heat, or the availability of nearby facilities that demand heat and power. Most coalmine facilities have a high electric demand, and excess electricity can almost always be sold to a local utility, although issues with grid interconnection could arise. Excess thermal energy, on the other hand, requires a nearby facility with a thermal demand, so most CBM gensets are not built for CHP. Coalbed methane projects do not qualify as PURPA qualifying facilities or small power producers, but most facilities do not require utility sales so this is not an issue.

\footnotetext{
${ }^{70}$ United States Environmental Protection Agency - Coalbed Methane Outreach Program, August 2010, http://www.epa.gov/cmop

${ }^{71}$ Natural Gas, The National Energy Education Development Project, 2008, http://www.need.org/needpdf/infobook_activities/SecInfo/NGasS.pdf
} 


\subsubsection{Environmental Issues}

Coalbed methane emissions account for about 10 percent of the United States' total methane emissions. ${ }^{72}$ Using this methane as an energy source would cut down on emissions and conserve natural resources. $\mathrm{CBM}$ has the same emission factors as natural gas, and must be treated accordingly, with the same emission control technologies.

\subsubsection{Availability, Cost, and Installed Capacity Data}

Availability: In 2006, 45 billion cubic feet of high quality CBM was collected and utilized, primarily through natural gas pipeline sales. About 8 billion cubic feet was emitted (not utilized). ${ }^{73}$

Costs: High quality CBM is interchangeable with natural gas, and is sold at the same rate. For coal mining operators, however, the gas can be used for on-site or nearby power generation.

Installed Capacity (Non-Utility): Information on the electric capacity and thermal output from coalbed methane is unavailable, as there are no significant power producers using CBM directly from coal mines.

\subsubsection{The Bottom Line}

Coalbed methane is a viable alternative to natural gas for most markets. The methane collected through drainage holes is of a very high quality, and can replace natural gas in any application with no necessary modifications. In addition, its use is beneficial to the environment. Onsite demand for electricity at coalmines is usually very high, but the thermal demand is usually too low to warrant CHP. While excess electricity can potentially be sold to the local utility, excess heat utilization requires a nearby facility with a thermal demand. Most coal mines opt to inject CBM into natural gas pipelines, because it is an easy source of revenue with minimal required investment.

\subsubsection{Wellhead Gas}

Oil and natural gas wells produce a methane gas that leaks and collects at the cap of the well. The gas is normally flared to prevent pressure buildup and explosions. The flare gas, however, is capable of producing heat and power for the well. It is not nearly as clean as the natural gas that is injected in pipelines, but its heating value averages around $1,100 \mathrm{Btu} / \mathrm{ft}^{3}$. Wellhead gas (also called casinghead gas) contains a great amount of impurities, so it must be thoroughly cleaned prior to use. Reciprocating engines and large turbines may require cleaner fuel than microturbines. Also, for onsite utilization applications, wells usually do not require much electric power to operate, and microturbines are better suited for small power production applications.

\footnotetext{
${ }^{72}$ United States Environmental Protection Agency - Coalbed Methane Outreach Program, August 2010, http://www.epa.gov/cmop

${ }^{73}$ Ibid.
} 


\subsubsection{Current Status}

Although some oil and gas wells use microturbines to turn their wellhead gas into a power source for the plant, most simply flare their gas into the atmosphere. The Rocky Mountain Oilfield Testing Center (part of the U.S. Department of Energy) conducted a project in 1998 running microturbines on wellhead gas. The project showed that Capstone $30 \mathrm{~kW}$ microturbines do not require any modifications or special cleaning devices to utilize the gas, although significantly more maintenance is required. ${ }^{74}$ Capstone has since provided microturbines for over 100 wellhead gas projects in the United States. The wells utilizing this technology can use wellhead gas to supply all of their power, including nearby compressor stations. For on-site wellhead gas applications, the demand for heat is almost always too low to justify CHP.

\subsubsection{Economics and Market Considerations}

The nature of wellhead gas limits its use to oil and gas wells and surrounding facilities. The gas at the cap of the well must be collected and flared (or utilized) on-site. Wells are required to flare their gas to reduce methane emissions, so they already have the collection and flaring of the gas in place and only need to install a CHP unit where the gas is flared. The only users of the electricity produced are the well itself and nearby compressor stations, which can usually be powered by a single $30 \mathrm{~kW}$ microturbine. However, it is likely that the well will produce more gas (large oil wells produce 300-400 million cubic feet of wellhead gas each day). Instead of flaring the remaining gas, it could be used to power secondary microturbines, as long as a utility or third party agrees to purchase the electricity produced. In addition, wellhead gas may qualify for the IRS Section 29 Tax Credit, and Federal and state governments may offer further incentives to users.

\subsubsection{Environmental Issues}

When wellhead gas is flared, many harmful byproducts are released into the atmosphere. When the gas is used as a power source, fewer emissions are released. In addition to this environmental benefit, using wellhead gas conserves natural resources by extracting more power from oil and natural gas reserves. Although some emissions are produced in the process of turning wellhead gas into power, these are negligible when compared to the emissions that would be produced from flaring.

\subsubsection{Availability, Cost, and Installed Capacity Data}

Availability: Wellhead gas is available at any oil or gas well, but it must be utilized on-site. There are over 1,000 oil and gas wells in the United States alone that could potentially benefit from wellhead gas utilization. ${ }^{75}$

Cost: Wellhead gas is free to the owners and operators of oil and gas wells. Chances are slight that it would ever be sold as a fuel, but if it were thoroughly cleaned of its impurities, it could potentially be sold as natural gas.

\footnotetext{
${ }^{74}$ Rocky Mountain Oilfield Testing Center Microturbine Project, Stacy \& Stacy Consulting, LLC, Prepared by: Michael J. Taylor, Project Manager.

${ }^{75}$ RIGDATA report, Fort Worth Texas, May 2006.
} 
Installed Capacity: There are many (over 100) wellhead gas projects underway in the United States using Capstone microturbines, both onshore and offshore, with over $3 \mathrm{MW}$ of total capacity. ${ }^{76}$

\subsubsection{The Bottom Line}

Using wellhead gas for power production at oil and gas wells allows them to benefit and potentially profit from this practice. There is little or no thermal demand at the well itself, so CHP is unlikely to be implemented unless an arrangement is made with a nearby facility. Any excess electricity produced can potentially be sold to the local utility, but this is not an option for offshore wells, and grid interconnection at other remote well locations can be difficult. Still, for small microturbine applications at oil and gas wells, wellhead gas makes an excellent fuel choice. There are over 1,000 oil and gas wells in the United States, so there are many sites that could potentially utilize the fuel in $30 \mathrm{~kW}$ microturbines, but the total potential capacity would be limited to about $30 \mathrm{MW}$, with very limited CHP utilization.

\subsection{PROCESSED OPPORTUNITY FUELS}

The final category of opportunity fuels are those that are already being processed and sold for fuel, but have so far only been used in niche applications. Orimulsion, an emulsified fuel from Venezuela was examined in the original 2006 report, but there continues to be no market for the fuel in the United States and it is unlikely that one will develop in the near future. Tire-derived fuel is the other opportunity fuel in this category, and it is examined in this section.

Tire-derived fuel is either processed at dedicated facilities and by the users of the fuel themselves. The processing costs vary depending on the degree of quality required for the given application. So far, tirederived fuel has been used in cement kilns and some industrial applications, but the fuel has not quite caught on in the CHP market.

\subsubsection{Tire-Derived Fuel}

Tire-derived fuel (TDF) is a solid fuel derived from scrap rubber tires. The fuel's properties are similar to coal and it can be burned in coal-fired stoker or fluidized bed boilers without modifications. Although the majority of coal-fired gensets do not qualify as CHP, according to the EIA 860 database, there are about 300 coal-fired CHP units in the United States 50 MW or smaller in size (totaling $3.9 \mathrm{GW}$ ) that could potentially utilize tire-derived fuel. ${ }^{77}$

There are 20 different grades of ground and shredded rubber from discarded tires, based on the size and consistency of the rubber chips. Typical TDF grades are 0.25 to 3 inches in size with varying degrees of wire removal. An average tire contains $280,000 \mathrm{Btu}$ - the equivalent of 2.5 gallons of oil or 20 pounds of coal. $^{78}$ TDF-coal cofiring blends are common. TDF performs similarly to coal, and has a heating value of

\footnotetext{
${ }^{76}$ Capstone representative, 2006.

${ }^{77}$ U.S. Energy Information Administration Form EIA-860 Database Annual Electric Generator Report, 2008.

${ }^{78}$ Tire Derived Fuel. February 2003. http://www.scraptire.com/2/TDF2.html
} 
about 16,000 Btu per pound. Provided below in Table 2 is a side-by-side comparison of the properties of coal and TDF, as obtained from an EPA study. ${ }^{79}$

Table 2. Coal and TDF: Fuel Analysis by Weight Percent (\%)

\begin{tabular}{|l|c|c|c|c|c|c|c|c|}
\hline Fuel & Carbon & Hydrogen & Oxygen & Nitrogen & Sulfur & Ash & Moisture & $\begin{array}{c}\text { Heating Value } \\
\text { (Btu/lb) }\end{array}$ \\
\hline Coal & 73.92 & 4.85 & 6.41 & 1.76 & 1.59 & 6.23 & 5.24 & 13,346 \\
\hline TDF & 83.87 & 7.09 & 2.17 & 0.24 & 1.23 & 4.78 & 0.62 & 15,500 \\
\hline
\end{tabular}

While TDF contains more carbon than coal, it contains less nitrogen, sulfur and oxygen, which will result in fewer $\mathrm{SO}_{\mathrm{x}}$ and $\mathrm{NO}_{\mathrm{x}}$ emissions. Tire-derived fuel also has less ash, less moisture, and a higher heating value than coal.

There are four steps followed when processing TDF:

1. Primary Shred - Double rotor shear shredder - strips 2 to 4 inches wide

2. Secondary Shred - Second shredder/granulator makes the finished size chips

3. Screening - Chips are screened with trommel or disc screens - oversize chips returned to \#2

4. Metal Removal - Metal bead and wire is removed with magnets

Once all of these steps have been performed, the tire chips are ready to be used as fuel. TDF is most often burned in boilers designed for coal. Minimal modifications are necessary, with only a slight increase in maintenance costs. When TDF is burned independently or in a high-percent blend, higher boiler temperatures are preferred in order to completely burn the fuel. Although the high flame temperature will slightly increase $\mathrm{NO}_{\mathrm{x}}$ emissions, the emissions from coal are higher and control technologies are already in place. With lower temperature boilers, the fuel is not always completely burned, more particulates are produced, and more maintenance is required. Still, cofiring tire-derived fuel almost always enhances boiler performance due to its high heating value and lower emissions. Fluidized bed, cyclone, and stokerfed boilers are all options for TDF combustion. While tire-derived fuel is a good candidate for many coal-fired CHP applications, so far it has only been utilized in large industrial operations.

\subsubsection{Current Status}

In the United States, about 300 million tires are discarded each year. Several hundred million tires are currently in landfills or tire piles (see Figure 14). Tires are now banned from most landfills and must be disposed of at dedicated sites. This makes it easier to collect the tires for tire-derived fuel. Most states are also pursuing abatement efforts to reduce used tire stockpiles through utilization or recycling. ${ }^{80}$

The producers of TDF collect used tires and use specialized machinery to shred, screen, and remove metal from the tires before it is sold as fuel to local consumers. Two dedicated TDF-to-energy facilities have been established, using specially designed boilers and producing a combined $50 \mathrm{MW}$ of electric power. Projects like these, however, are few and far between - cement kilns, utilities, and industrial facilities have been the primary users of tire-derived fuel. At these facilities, it is used for heat, and often mixed with coal and/or biomass fuels.

79 Joel I. Reisman, Paul M. Lemieux, Air Emissions from Scrap Tire Combustion, EPA, Oct. 1997

${ }^{80}$ U.S. Scrap Tire Management Summary 2005-2009, Rubber Manufacturers Association, October 2011. 
TDF has not yet caught on in the CHP industries, but it has the potential to replace or supplement coal in nearly any boiler/steam turbine application. In the year 2008, about $4 \mathrm{GW}$ of electricity and 300 trillion Btu's of thermal output were produced by coalfired CHP units $50 \mathrm{MW}$ or smaller. ${ }^{81}$ In many of these cases, cofiring with or switching to tire-derived fuel could prove beneficial.

\subsubsection{Economics and Market Considerations}

The cost of tire-derived fuel is

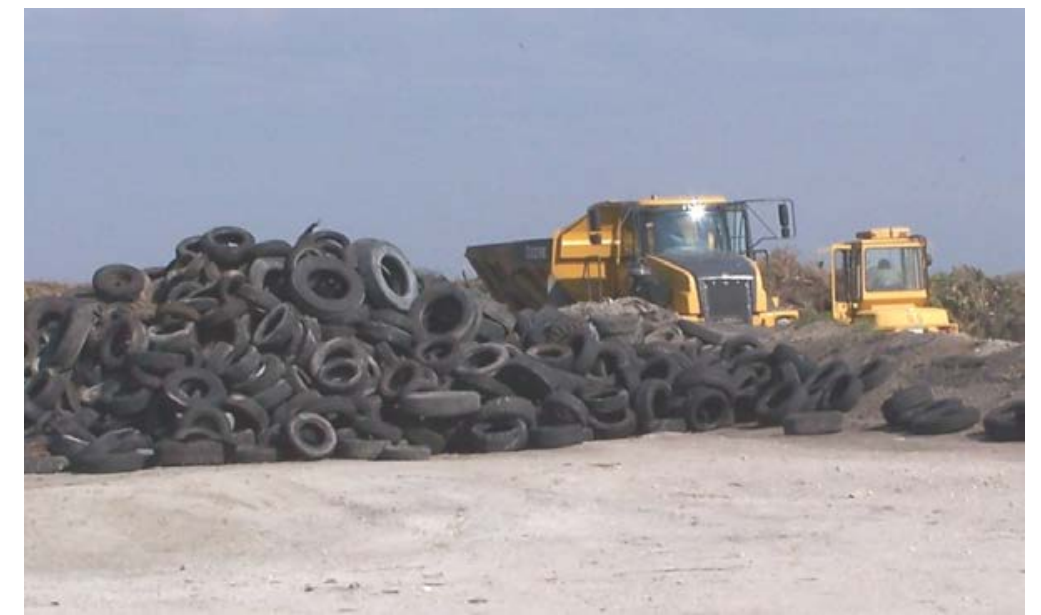

Figure 14. Tire Piles - A Potential Source of Tire-Derived Fuel

(Source: http://www.brevardcounty.us/SolidWaste/TourFacility) generally tied to the cost of coal, with TDF suppliers setting their costs slightly below the cost of coal on an energy basis. Total costs, not including transportation, typically range from $\$ 40-\$ 90$ per ton, or about \$2-\$4 per MMBtu when transportation is included. Cofiring with coal is the most popular method of TDF energy production because coal-fired boilers already exist and TDF can be easily co-fired with no modifications. Cofiring saves money since TDF is less expensive and contains less sulfur than coal. When attempting to fire 100 percent TDF in existing coal-fired boilers, heavily processed TDF is required, sometimes costing more than coal. As a result, there is little incentive for coal users to make a complete switch. For 100 percent tire-derived fuel, boilers specifically designed for TDF are recommended.

The growing demand for TDF has begun to create a supply infrastructure with manufacturers and brokers. For the entire United States, the current users of TDF are:, Pulp \& Paper Mills (34\%), Cement Kilns (29\%), Utility Boilers (16\%), Industrial Boilers (11\%), and Dedicated Tire to Energy (10\%). ${ }^{82}$ Recently, TDF use at cement kilns and industrial boilers has been on the rise. All of these applications, except the two dedicated tire-to-energy facilities, utilize TDF strictly for heat. Tire-derived fuel has not yet broken into the CHP market.

TDF generally does not require any special handling ${ }^{83}$, and since the Btu content is so high, transportation is not as costly as for biomass and other opportunity fuels. Still, transportation accounts for a good portion of the delivered cost, which varies greatly depending on distance, volume and transport mode. Because of this, it is preferable to obtain TDF from a nearby location. Most TDF processing plants are located close to large tire piles, which are common throughout the country, most prominently in the Midwest and Northeast regions. Government subsidies for waste tires are available in many states, and this can significantly reduce the cost of the fuel. In certain cases, states without subsidies will purchase tires from nearby subsidized states because it is actually less costly than obtaining the tires at home. For example, TDF users and producers in California often purchase tires from Utah, Oregon, and Arizona, since they all have subsidies on waste tires. Once the tires are obtained, they are ground, shredded, and processed for use. With average market conditions, the price of TDF is slightly less than the price of coal on a Btu basis, and it performs nearly as well.

\footnotetext{
${ }^{81}$ U.S. Energy Information Administration Form EIA-860 Database Annual Electric Generator Report, 2008.

${ }^{82}$ U.S. Scrap Tire Management Summary 2005-2009, Rubber Manufacturers Association, October 2011.

${ }^{83}$ While the fuel does not require special handling, TDF ash contains some heavy metals that require special disposal arrangements
} 


\subsubsection{Environmental Issues}

The sulfur content of tire-derived fuel, while less than coal, is still considerable at over one percent. The nitrogen content is extremely low, so $\mathrm{NO}_{\mathrm{x}}$ emissions are not an issue for most potential CHP installations. TDF ash has a greater carbon content than coal ash, but TDF produces less ash than coal. TDF combustion can create an unpleasant odor, so CHP systems may face opposition from local constituents.

Although tire-derived fuel is not renewable in the classic sense of the word, tires are always being produced and the stockpile of waste tires in the United States grows each year. The utilization of TDF reduces waste and promotes the conservation of natural resources.

\subsubsection{Availability, Cost, and Installed Capacity Data}

Availability: In the United States, about 300 million tires are discarded each year and several hundred million tires are still disposed of in landfills. ${ }^{84}$ Only a small fraction of these tires are used for TDF. Currently, the fuel is not produced in abundance, only enough to supply the current demand. If the market grows, production will likely increase.

Costs: TDF costs anywhere from $\$ 40-\$ 90$ per ton, depending on the local supply and demand, as well as the cost of coal, which tends to fall in the same range (though TDF has a greater energy density). Most coal-fired boilers do not require any modifications to switch to TDF, which has similar characteristics to coal. More maintenance may be required, however, due to incomplete burning at low boiler temperatures, as well as removing metal scraps and wires often embedded in the tires.

Installed Capacity: In 2012, the installed capacity of TDF units was $31 \mathrm{MW}{ }^{85}$ All of this electric capacity comes from one dedicated TDF-to-energy facility.

\subsubsection{The Bottom Line}

Tire-derived fuel is an ideal opportunity fuel that can replace or be cofired with coal in nearly any application. A supply infrastructure has already been created, the fuel is usually available at a lower price (or at least competitive with coal), and fewer emissions are produced. Although many CHP opportunities are available, TDF is best suited for large utility or industrial applications, and the market so far has consisted of cement kilns, utilities, dedicated facilities, industrial cofiring operations, or any sizeable energy user with coal generation on-site.

${ }^{84}$ U.S. Scrap Tire Management Summary 2005-2009, Rubber Manufacturers Association, October 2011.

${ }^{85}$ U.S. Energy Information Administration Form EIA-860 Database Annual Electric Generator Report, 2012. 


\subsection{SUMMARY OF FUEL ATTRIBUTES AND PERFORMANCE}

The attributes of the opportunity fuels evaluated in this report are summarized in Table 3.

Table 3. Summary of Opportunity Fuel Attributes

\begin{tabular}{|c|c|c|c|c|c|}
\hline Fuel & Source(s) & $\begin{array}{l}\text { Energy } \\
\text { Content }\end{array}$ & $\begin{array}{l}\text { RPS } \\
\text { Eligible }\end{array}$ & $\begin{array}{l}\text { Environmental } \\
\text { Pros/Cons }\end{array}$ & Barriers to CHP \\
\hline $\begin{array}{l}\text { Anaerobic } \\
\text { Digester } \\
\text { Gas (ADG) }\end{array}$ & $\begin{array}{l}\text { Wastewater } \\
\text { treatment plants, } \\
\text { Dairy and Swine } \\
\text { Farms }\end{array}$ & $\begin{array}{l}400-600 \\
\mathrm{Btu} / \mathrm{ft}^{3} \\
\text { (gas) }\end{array}$ & Yes & $\begin{array}{l}\text { Reduces methane } \\
\text { emissions and odors, but } \\
\text { emits some carbon } \\
\text { monoxide and NOx when } \\
\text { combusted }\end{array}$ & $\begin{array}{l}\text { Cost of anaerobic digester, } \\
\text { demand for electricity/heat } \\
\text { on farms }\end{array}$ \\
\hline $\begin{array}{l}\text { Biomass } \\
\text { Gas }\end{array}$ & $\begin{array}{l}\text { Produced from } \\
\text { gasifiers using } \\
\text { biomass } \\
\text { feedstocks }\end{array}$ & $\begin{array}{l}150-800 \\
\text { Btu/ft }{ }^{3} \\
\text { (gas) }\end{array}$ & Yes & $\begin{array}{l}\text { Utilizes renewable fuels, } \\
\text { but emissions depend on } \\
\text { feedstock and gasifier } \\
\text { technology }\end{array}$ & $\begin{array}{l}\text { Advanced, low-cost } \\
\text { gasification technologies } \\
\text { have not materialized }\end{array}$ \\
\hline $\begin{array}{l}\text { Black } \\
\text { Liquor }\end{array}$ & $\begin{array}{l}\text { Pulp and paper } \\
\text { mills }\end{array}$ & $\begin{array}{l}5,000- \\
7,000 \\
\text { Btu/lb } \\
\text { (solid) }\end{array}$ & No & $\begin{array}{l}\text { Contains sulfur and } \\
\text { nitrogen, so SOx and NOx } \\
\text { emissions can be a concern }\end{array}$ & $\begin{array}{l}\text { Already extensively } \\
\text { utilized by pulp and paper } \\
\text { industry }\end{array}$ \\
\hline $\begin{array}{l}\text { Blast } \\
\text { Furnace } \\
\text { Gas }\end{array}$ & $\begin{array}{l}\text { Steel-making } \\
\text { blast furnaces }\end{array}$ & $\begin{array}{l}100-150 \\
\mathrm{Btu} / \mathrm{ft}^{3} \\
\text { (gas) }\end{array}$ & No & $\begin{array}{l}\text { High carbon content } \\
\text { (CO2), extremely high } \\
\text { nitrogen content (NOx) }\end{array}$ & $\begin{array}{l}\text { Limited number of steel } \\
\text { mills, many already } \\
\text { utilizing }\end{array}$ \\
\hline $\begin{array}{l}\text { Coalbed } \\
\text { Methane }\end{array}$ & $\begin{array}{l}\text { Underground } \\
\text { coal mines }\end{array}$ & $\begin{array}{l}1,000 \\
\mathrm{Btu} / \mathrm{ft}^{3} \\
\text { (gas) }\end{array}$ & No & $\begin{array}{l}\text { Reduces methane } \\
\text { emissions, but emits some } \\
\text { NOx when combusted }\end{array}$ & $\begin{array}{l}\text { Use is limited at/ near } \\
\text { underground coal mines }\end{array}$ \\
\hline $\begin{array}{l}\text { Coke Oven } \\
\text { Gas }\end{array}$ & $\begin{array}{l}\text { Integrated steel } \\
\text { mills, merchant } \\
\text { coke plants }\end{array}$ & $\begin{array}{l}500 \\
\mathrm{Btu} / \mathrm{ft}^{3} \\
(\mathrm{gas})\end{array}$ & No & $\begin{array}{l}\text { SOx, NOx, particulates are } \\
\text { produced when combusted }\end{array}$ & $\begin{array}{l}\text { Limited number of plants } \\
\text { that produce the fuel }\end{array}$ \\
\hline $\begin{array}{l}\text { Crop } \\
\text { Residues }\end{array}$ & $\begin{array}{l}\text { Agricultural } \\
\text { byproducts }\end{array}$ & $\begin{array}{l}6,000- \\
7,500 \\
\text { Btu/lb } \\
\text { (solid) }\end{array}$ & Yes & $\begin{array}{l}\text { Utilizing for power reduces } \\
\text { emissions compared to } \\
\text { open burning }\end{array}$ & $\begin{array}{l}\text { Collecting, processing and } \\
\text { transporting the fuel can be } \\
\text { costly }\end{array}$ \\
\hline $\begin{array}{l}\text { Food } \\
\text { Processing } \\
\text { Waste }\end{array}$ & $\begin{array}{l}\text { Food processing } \\
\text { facilities }\end{array}$ & $\begin{array}{l}4,000- \\
7,000 \\
\text { Btu/lb } \\
\text { (solid) }\end{array}$ & Yes & $\begin{array}{l}\text { Renewable biomass } \\
\text { resource, burns cleaner } \\
\text { than fossil fuels; ash } \\
\text { content can be high }\end{array}$ & $\begin{array}{l}\text { Many different types of } \\
\text { waste, some with high } \\
\text { moisture content }\end{array}$ \\
\hline $\begin{array}{l}\text { Forest } \\
\text { Residues }\end{array}$ & $\begin{array}{l}\text { Lumber } \\
\text { operations }\end{array}$ & $\begin{array}{l}\text { 6,000- } \\
8,000 \\
\text { Btu/lb } \\
\text { (solid) }\end{array}$ & Yes & $\begin{array}{l}\text { Long term sustainability is } \\
\text { questionable due to slow } \\
\text { growth period; significant } \\
\text { NOx, carbon monoxide } \\
\text { and particulate emissions } \\
\text { when combusted }\end{array}$ & $\begin{array}{l}\text { Collecting, processing and } \\
\text { transporting the fuel can be } \\
\text { costly }\end{array}$ \\
\hline $\begin{array}{l}\text { Industrial } \\
\text { VOCs }\end{array}$ & Chemical plants & $\begin{array}{l}\text { Varies } \\
\text { (gas) }\end{array}$ & No & $\begin{array}{l}\text { Reduces emissions of } \\
\text { volatile organic } \\
\text { compounds }\end{array}$ & $\begin{array}{l}\text { Difficult to use as a stand- } \\
\text { alone fuel due to dilute } \\
\text { nature and high- } \\
\text { temperature combustion } \\
\text { requirement }\end{array}$ \\
\hline $\begin{array}{l}\text { Landfill } \\
\text { Gas }\end{array}$ & Landfills & $\begin{array}{l}400-550 \\
\mathrm{Btu} / \mathrm{ft}^{3} \\
\text { (gas) }\end{array}$ & Yes & $\begin{array}{l}\text { Reduces methane } \\
\text { emissions, but emits some } \\
\text { NOx when combusted }\end{array}$ & $\begin{array}{l}\text { Landfills located in remote } \\
\text { locations - need host site } \\
\text { or power export }\end{array}$ \\
\hline Municipal & Various solid & $3,000-$ & No & Reduces amount of waste & Difficult to site, strict \\
\hline
\end{tabular}




\begin{tabular}{|c|c|c|c|c|c|}
\hline Fuel & Source(s) & $\begin{array}{l}\text { Energy } \\
\text { Content }\end{array}$ & $\begin{array}{l}\text { RPS } \\
\text { Eligible }\end{array}$ & $\begin{array}{l}\text { Environmental } \\
\text { Pros/Cons }\end{array}$ & Barriers to CHP \\
\hline $\begin{array}{l}\text { Solid } \\
\text { Waste }\end{array}$ & waste streams & $\begin{array}{l}6,000 \\
\text { Btu/lb } \\
\text { (solid) }\end{array}$ & & $\begin{array}{l}\text { for landfills, but } \\
\text { combustion releases many } \\
\text { pollutants }\end{array}$ & $\begin{array}{l}\text { emission standards, } \\
\text { heterogeneous fuel } \\
\text { composition }\end{array}$ \\
\hline $\begin{array}{l}\text { Petroleum } \\
\text { Coke }\end{array}$ & $\begin{array}{l}\text { Byproduct of } \\
\text { petroleum } \\
\text { refineries }\end{array}$ & $\begin{array}{l}14,000 \\
\text { Btu/lb } \\
\text { (solid) }\end{array}$ & No & $\begin{array}{l}\text { High sulfur and nitrogen } \\
\text { content, resulting in } \\
\text { SOx/NOx emissions }\end{array}$ & $\begin{array}{l}\text { Availability depends on } \\
\text { petroleum industry and } \\
\text { foreign markets }\end{array}$ \\
\hline $\begin{array}{l}\text { Refinery } \\
\text { Fuel Gas }\end{array}$ & $\begin{array}{l}\text { Byproduct of } \\
\text { petroleum } \\
\text { refineries }\end{array}$ & $\begin{array}{l}\text { Varies } \\
\text { (gas) }\end{array}$ & No & $\begin{array}{l}\text { Utilizing refinery fuel gas } \\
\text { prevents some emissions } \\
\text { from flaring }\end{array}$ & $\begin{array}{l}\text { Requires more gas cleanup } \\
\text { than other utilization } \\
\text { practices }\end{array}$ \\
\hline $\begin{array}{l}\text { Sludge } \\
\text { Waste }\end{array}$ & $\begin{array}{l}\text { Wastewater } \\
\text { treatment plants, } \\
\text { pulp/paper mills }\end{array}$ & $\begin{array}{l}3,000- \\
4,000 \\
\text { Btu/lb } \\
\text { (solid) }\end{array}$ & Yes & $\begin{array}{l}\text { Disposes of waste sludge, } \\
\text { but creates NOx and } \\
\text { particulate emissions }\end{array}$ & $\begin{array}{l}\text { High moisture content; } \\
\text { anaerobic digestion may be } \\
\text { preferable }\end{array}$ \\
\hline $\begin{array}{l}\text { Textile } \\
\text { Waste }\end{array}$ & Textile mills & $\begin{array}{l}\text { Varies } \\
\text { (solid) }\end{array}$ & No & $\begin{array}{l}\text { Typically used in a 5-10 } \\
\text { percent blend, which will } \\
\text { not contribute heavily to } \\
\text { emissions }\end{array}$ & $\begin{array}{l}\text { Most practical when co- } \\
\text { fired with coal or another } \\
\text { solid fuel }\end{array}$ \\
\hline $\begin{array}{l}\text { Tire- } \\
\text { Derived } \\
\text { Fuel }\end{array}$ & Scrap tires & $\begin{array}{l}14,000- \\
18,000 \\
\text { Btu/lb } \\
\text { (solid) }\end{array}$ & No & $\begin{array}{l}\text { High sulfur content, but } \\
\text { lower nitrogen content than } \\
\text { coal }\end{array}$ & $\begin{array}{l}\text { Limited amount of scrap } \\
\text { tires, and other recycling } \\
\text { options seem to be } \\
\text { preferred }\end{array}$ \\
\hline $\begin{array}{l}\text { Wellhead } \\
\text { Gas }\end{array}$ & Oil wells & $\begin{array}{l}1,100 \\
\text { Btu/ft } \\
\text { (gas) }\end{array}$ & No & $\begin{array}{l}\text { Reduces emissions } \\
\text { compared to flaring }\end{array}$ & $\begin{array}{l}\text { Limited to small } \\
\text { installations at oil wells }\end{array}$ \\
\hline $\begin{array}{l}\text { Wood } \\
\text { waste }\end{array}$ & $\begin{array}{l}\text { Construction and } \\
\text { demolition } \\
\text { debris, clippings, } \\
\text { lumber mills }\end{array}$ & $\begin{array}{l}6,000- \\
8,000 \\
\text { Btu/lb } \\
\text { (solid) }\end{array}$ & Yes & $\begin{array}{l}\text { Produces significant NOx, } \\
\text { carbon monoxide and } \\
\text { particulate emissions; some } \\
\text { wood waste sources have } \\
\text { high levels of impurities }\end{array}$ & $\begin{array}{l}\text { Collecting, processing and } \\
\text { transporting the fuel can be } \\
\text { costly }\end{array}$ \\
\hline
\end{tabular}

There are a large number of alternative fuels with an opportunity to break into the CHP marketplace. Each fuel has its advantages and disadvantages, but they all have the potential to generate power for certain markets. For many opportunity fuels, the market is limited to sites that produce the fuel as a byproduct. Sometimes the fuel is marketable to areas immediately surrounding the production facilities, but transportation costs are a limiting factor. Even with these limitations, some of these fuels appear to have a great deal of potential in their own niche markets. Some other fuels look promising enough to become serious players in the distributed power industry. Table 4 summarizes the attributes and performance (availability, heating value, costs, emissions/environmental concerns, CHP potential, and limitations) of each opportunity fuel. Then, a score is derived for each fuel, the results are summarized, and the six most promising fuels are chosen for further evaluation. 
Table 4. Opportunity Fuel Performance Matrix

\begin{tabular}{|c|c|c|c|c|c|c|c|c|}
\hline Opportunity Fuel & Availability & $\begin{array}{l}\text { Heating } \\
\text { Value }\end{array}$ & $\begin{array}{l}\text { Fuel } \\
\text { Cost }\end{array}$ & $\begin{array}{l}\text { Equipment } \\
\text { Cost }\end{array}$ & $\begin{array}{l}\text { Emissions / } \\
\text { Environment }\end{array}$ & $\begin{array}{l}\text { CHP } \\
\text { Potential }\end{array}$ & Rating & Limitations \\
\hline Anaerobic Digester Gas & & C & & $\bigcirc$ & & & 4.5 & Need anaerobic digester \\
\hline Biomass Gas & 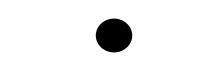 & C & (1) & $\bigcirc$ & & (1) & 3.5 & Gasifiers extremely expensive \\
\hline Black Liquor & $\bigcirc$ & ( & & C & (1) & (1) & 3.0 & Most BL already used up by mills \\
\hline Blast Furnace Gas & $\bigcirc$ & $\bigcirc$ & & (1) & (1) & $\bigcirc$ & 2.0 & Limited availability, low Btu \\
\hline Coalbed Methane & $\bigcirc$ & & & & & (1) & 5.0 & Coal mines - lack CHP demand \\
\hline Coke Oven Gas & $\bigcirc$ & 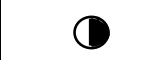 & & O & (1) & (1) & 3.0 & Availability - most already used \\
\hline Crop Residues & ( & & ( & (1) & & (1) & 3.0 & Difficulty in gathering/transport \\
\hline Food Processing Waste & $\mathbb{C}$ & 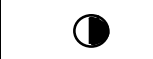 & & ( & & (1) & 4.0 & Limited market, broad category \\
\hline Forest Residues & & & & (1) & & a & 4.0 & Remote locations, can be costly \\
\hline Industrial VOCs & $\bigcirc$ & & C & (1) & C & C & 2.0 & Must be used w/ NG turbine \\
\hline Landfill Gas & & ( & & (1) & & C & 4.0 & Remote location, no CHP demand \\
\hline MSW / RDF & & & & $\bigcirc$ & & & 3.0 & Low heating value, contaminants \\
\hline Petroleum Coke & & & & (1) & $\bigcirc$ & O & 3.5 & Contaminants, best for large apps \\
\hline Refinery Fuel Gas & a & & & $\bigcirc$ & (1) & (1) & 3.5 & Contaminants, limited fuel source \\
\hline Sludge Waste & & 0 & & 0 & 0 & $\cap$ & 2.5 & Low heating value, contaminants \\
\hline Textile Waste & 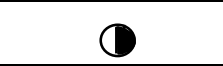 & C & & (1) & (1) & 0 & 3.0 & Must be cofired; larger apps \\
\hline Tire-Derived Fuel & & & 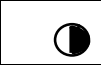 & (1) & (1) & 0 & 4.0 & Best suited for large apps \\
\hline Wellhead Gas & 0 & & & (1) & (1) & 0 & 3.5 & Oil / gas wells - no CHP demand \\
\hline Wood Waste & & & & (1) & & (1) & 4.5 & Waste may have contaminants \\
\hline
\end{tabular}

Key: $\quad$ = excellent / not an issue, $\mathbb{O}=$ average / could become an issue, $\bigcirc=$ poor / major issue 
Each fuel's positive and negative attributes are discussed below, and the most promising fuels are chosen for further evaluation in this report.

*Anaerobic Digester Gas (4.5) - Very promising opportunity fuel for wastewater treatment plants (municipal and industrial), and to a lesser extent, animal farms. The fuel is especially beneficial in cases where a digester has already been installed, and is an ideal choice for CHP applications. Anaerobic digester gas is a promising opportunity fuel and will be examined further in the following sections.

Biomass Gas (3.5) - There are three things preventing biomass gas from becoming a serious contender in the CHP market: the cost of advanced gasification systems, the difficulties involved with hot gas cleanup, and the lack of a reliable collection/processing infrastructure for biomass fuels. Biomass gas could be $a$ promising opportunity fuel for larger projects, but advanced gasifiers have not yet entered the commercialization process, and it is uncertain if they will be able to overcome their drawbacks (high capital and maintenance costs, gas cleanup difficulties) in the near future. Biomass gas will not be considered for further evaluation in this report.

Black Liquor (3.0) - Black liquor is a strong opportunity fuel for the pulp and paper mills that produce it. However, these mills already utilize black liquor to their benefit, and there is little to no market left for the fuel. Black liquor will not be considered for further evaluation in this report.

Blast Furnace Gas (2.0) - An extremely low heating value and limited availability make this fuel inadequate for outside markets. Iron and steel mills utilize it for additional heat, but that is the extent of its usefulness. Blast furnace gas will not be considered for further evaluation in this report.

*Coalbed Methane (4.5) - Coalbed methane is a high-quality fuel, and is essentially free to coal mine owners and operators. However, the demand for heat and power at a coal mine is minor compared to the potential energy produced, so CHP can only be applied when nearby facilities agree to pick up the load. Or, the gas can be transported through natural gas pipelines to its destination. Although not ideal for combined heat and power applications, coalbed methane is a promising fuel and will be examined further in the following sections.

Coke Oven Gas (3.0) - This fuel is utilized by iron/steel mills and petroleum refineries to provide additional heat and power. Although some facilities do not utilize coke oven gas to its full extent, the remaining market is thin, and the fuel is only beneficial to those that produce it. Coke oven gas will not be considered for further evaluation in this report.

Crop Residues (3.0) - The labor involved with gathering and transporting crop residues causes their cost to be the highest among the biomass fuels. Until a better infrastructure is created, or dedicated energy crops are introduced, crop residues will remain too expensive for economic energy production. Crop residues will not be considered for further evaluation in this report.

Food Processing Waste (4.0) - While food processing waste is a strong fuel choice for certain food processing facilities, the category is too broad to make generalizations. The availability and cost data for this fuel category is lacking, and decisions must be made on a case-by-case basis. Food processing waste will not be considered for further evaluation in this report.

Industrial VOCs (2.0) - Since the VOC-air mixture collected from industrial facilities is too dilute to be an effective stand-alone fuel, it must be cofired in natural gas turbines. For this reason, it is not a very promising opportunity fuel. Industrial VOCs will not be considered for further evaluation in this report. 
*Landfill Gas (4.5) - Although it is an essentially free and plentiful fuel source, landfill gas must be utilized either on-site or within a 10-15 miles of a landfill. When utilized on-site, excess electricity can be sold to the power grid, but the thermal demand for landfills is too low to warrant CHP applications, unless it is utilized by a nearby facility. Even so, landfill gas is one of the most promising opportunity fuels. The market is strong, it is being heavily backed by the EPA, and it can provide a sizeable revenue for landfill operators. Landfill gas is a promising fuel and will be examined further in the following sections.

Municipal Solid Waste and Refuse Derived Fuel (3.0) - Aside from its cost, MSW and RDF are inferior fuel. It has a low heating value, high moisture content, and many impurities. Gasification of waste is almost always preferred, and new technologies are making this possible. MSW does not have a very promising future. Municipal solid waste and refuse derived fuel will not be considered for further evaluation in this report.

Orimulsion (2.5) - Despite the fact that Orimulsion is a low-cost fuel that performs fairly well, there is currently no market for the fuel in the United States. Until the U.S. market barrier is broken, Orimulsion can only be considered for overseas projects. Orimulsion will not be considered for further evaluation in this report.

Petroleum Coke (3.5) - While there is a plentiful supply of Petroleum Coke, and the price is lower than coal, it is a dangerous substance and contains a great deal of contaminants. So far, it has only been applied to large-scale operations, and it is not well suited for small CHP projects. Petroleum coke will not be considered for further evaluation in this report.

Refinery Fuel Gas (3.5) - Refinery fuel gas is produced in high quantities at oil refineries, but they already utilize the gas heavily for on-site applications, only flaring excess gas sporadically. Gas treatment and storage would likely be required for CHP applications. Additionally, facilities would need to pipeline the gas from refineries, whose locations are fairly limiting. Refinery fuel gas will not be considered for further evaluation in this report.

Sludge Waste (2.5) - Like MSW, the most positive aspect of Sludge Waste is its cost. The heating value is even lower than MSW, and the moisture content higher. It does not make a very good fuel, and anaerobic digestion is almost always preferred. Sludge waste will not be considered for further evaluation in this report.

Textile Waste (3.0) - As a stand-alone fuel, the quality of textile waste is poor. It must be cofired with coal in large-scale applications to become effective. Even then, its usefulness is limited to reducing fuel costs for textile mills. Textile waste will not be considered for further evaluation in this report.

*Tire-Derived Fuel (4.0) - While tire-derived fuel performs similarly to coal, like coal, it is best suited for large-scale industrial operations. However, it could be a potential fuel source for steam turbines, and it is an excellent candidate for CHP. The availability is plentiful, and its price is about the same as or less than coal. Tire-derived fuel is a promising fuel and will be examined further in the following sections.

Wellhead Gas (3.5) - The gas collected from oil and gas well caps is full of contaminants, but high in heating value. The market is currently limited to oil and gas wells and their surrounding areas, and as the demand for energy at oil and gas wells is small, CHP is only beneficial when a nearby facility can utilize the heat. However, most wells are located either offshore or in very remote areas, and the demand for onsite power production is very small. Although not ideal for combined heat and power applications, wellhead gas could be a promising opportunity fuel for small on-site applications at oil and gas wells. The potential for significant new capacity at these sites is extremely limited, so the fuel will not be considered for further evaluation in this report. 
*Wood (Forest Residues) (4.0) - Forest residues, or harvested wood, is heavily utilized at industrial sites, but there is still plenty of room for significant growth. The price to obtain processed forest residues can be relatively high, especially when transportation costs are considered, but the fuel performs well and resources are plentiful. While best suited for large-scale applications, it is also an ideal fuel for steam turbines in the 5-50 MW range. Forest residues are a promising fuel and will be examined further in the following sections.

*Wood (Urban Wood Waste) (4.5) - Urban wood waste can come from a variety of sources, and is produced ubiquitously throughout the United States, concentrated near population centers. The price to obtain processed urban wood waste is invariably lower than forest residues or harvested wood, and transportation distances are less likely to be an issue. However, depending on the source, urban wood waste may contain some contaminants and impurities that raise emission levels and must be removed prior to burning. Urban Wood Waste is a promising fuel and will be examined further in the following sections.

\subsection{CHAPTER 2 SUMMARY}

After summarizing the attributes, benefits, and drawbacks of each opportunity fuel, biomass gas, black liquor, blast furnace gas, coke oven gas, crop residues, food processing waste, industrial VOCs, MSW, petroleum coke, refinery fuel gas, sludge waste, textile waste and wellhead gas were eliminated from further evaluation. For most of these fuels, the quality is too low, the price is too high, or the market is not strong enough. Other fuels are only suitable for cofiring or large-scale industrial applications. For the remaining six opportunity fuels (each rated 4.0 or higher), a more in-depth analysis is performed, starting with a description of the prime mover technologies, and followed by an examination of each fuel's availability and current status for CHP applications.

Opportunity Fuels Considered for Further Evaluation:

- $\quad$ Anaerobic Digester Gas

- Coalbed Methane

- $\quad$ Forest Residues

- Landfill Gas

- Tire-Derived Fuel

- Urban Wood Waste 



\section{CHP TECHNOLOGIES FOR OPPORTUNITY FUELS}

Opportunity fuels can be used to generate power with prime movers including steam turbines, combustion turbines, reciprocating engines, microturbines and fuel cells. ${ }^{86}$ Each of these technologies can be configured to capture waste heat and produce useful thermal output, employing the units as cogeneration or combined heat and power (CHP). For solid fuels, a steam turbine and boiler unit is the only commercial technology option, with gasification options being developed to convert solids to a combustible gas, but these are not ready for commercial use at this point. ${ }^{87}$ Gaseous fuels can also be burned in a boiler to produce steam, but other prime mover technologies are also options for gaseous opportunity fuels, often better-suited for smaller CHP applications. Each technology has its benefits and drawbacks, depending primarily on fuel characteristics and site electrical and thermal loads.

This chapter examines the various technologies used for producing power with opportunity fuels. An introduction and brief overview of the leading technologies (steam turbine, combustion turbine, reciprocating engine, microturbine, fuel cell) is given, discussing the history, operation, emissions, efficiency and costs associated with each technology. Then, equipment modifications and specializations required for opportunity fuels are discussed, and the associated costs are estimated. Installation costs for power generating equipment have risen substantially since data was collected for the 2006 report, and this 2015 update reflects recent estimates for opportunity fueled CHP systems, including pretreatment costs. Maintenance issues are also identified for each technology and fuel, with estimated costs also surpassing those found in the 2006 report. Finally, the advantages and disadvantages of each technology are considered, and potential applications for the different prime movers are discussed. At the end of the chapter, the equipment and maintenance cost ranges for each fuel are summarized in table form.

\subsection{STEAM TURBINES}

Steam turbines were invented in 1884 by Englishman Charles Parsons as an alternative to the reciprocating steam engines that dominated the era. They were first brought to America in the early 1900 's for industrial operations and power generating applications. The steam turbines produced electricity much more efficiently than reciprocating steam engines, and quickly became the American standard.

Throughout the 1900's, new developments in steam turbines were made, making them more efficient and capable of producing electricity at a relatively low cost. Improving the metallurgy of the turbines allowed for higher temperature and pressure steam, which improved the turbine performance. Electric efficiencies were improved to about 33 percent for utility-scale units. However, the advent of combustion turbines slowed down the progress of the steam turbine, as combustion turbines offer higher electric efficiencies and can be sited more quickly. Still, steam turbines remain a consistent and reliable source of power, particularly for large coal power plants, but also for biomass power facilities.

\footnotetext{
${ }^{86}$ Stirling Engines were considered in the previous opportunity fuel CHP analysis as a future technology, but they have been primarily limited to residential micro CHP installations in Europe, and this is where Stirling Engine CHP development has been focused. Stirling Biopower is currently marketing the $55 \mathrm{~kW}$ PowerUnit originally developed by STM Power Inc. (who went out of business in 2007) but the viability of U.S. CHP installations is uncertain.

${ }^{87}$ Advanced gasifiers were previously evaluated as an emerging technology with future potential, but a decline in natural gas prices and difficulties with reducing installation and maintenance costs have hindered gasifier economics and stalled their development. The focus of this report is current CHP opportunities, so gasification technologies are not evaluated.
} 
There are three types of steam turbines that are used for power generation and CHP applications:

1. Condensing steam turbines - these turbines are primarily used for electric power production, exhausting steam to a condenser where it is condensed into water before being heated again in the boiler. The steam is not used for external heating purposes, as condensing and re-use ensures maximum electric efficiency.

2. Extraction turbines - these turbines are often used at industrial sites that require different levels of steam pressures various process heating requirements. Steam is extracted at specific locations along the turbine while the majority of steam works though the entire turbine, and the remaining steam is recirculated through a smaller condenser, and back to the boiler.

3. Back-pressure steam turbines - these turbines tend to produce a small amount of electricity relative to steam - they essentially work like a pressure-reducing valve, using the turbine to reduce the pressure of boiler-generated steam to the level required for industrial heating applications, producing electricity from the turbine.

While condensing steam turbines have been used for large-scale utility power operations, back-pressure and extraction steam turbines have proven themselves successful in many industrial CHP applications. For industrial sites that demand large amounts of pressurized steam as well as electric power, these types of steam turbines are an ideal fit. They are often used at pulp and paper mills, wood manufacturing plants and other industrial facilities, powered by boilers using traditional fuels like natural gas, fuel oil or coal, as well as opportunity fuels such as black liquor, sludge waste and wood waste.

\subsubsection{Operation}

In steam turbine systems, a high-pressure boiler is used to generate steam. Water enters the boiler, where heat is transferred from high-temperature fuel combustion to create the steam that enters the turbine. The steam causes the turbine blades to rotate, creating power that is converted into electricity with a generator. With condensing steam turbines, a condenser and pump are used to collect and recirculate the leftover steam and water, feeding it into the boiler and completing the cycle. This cycle is illustrated in Figure 15.

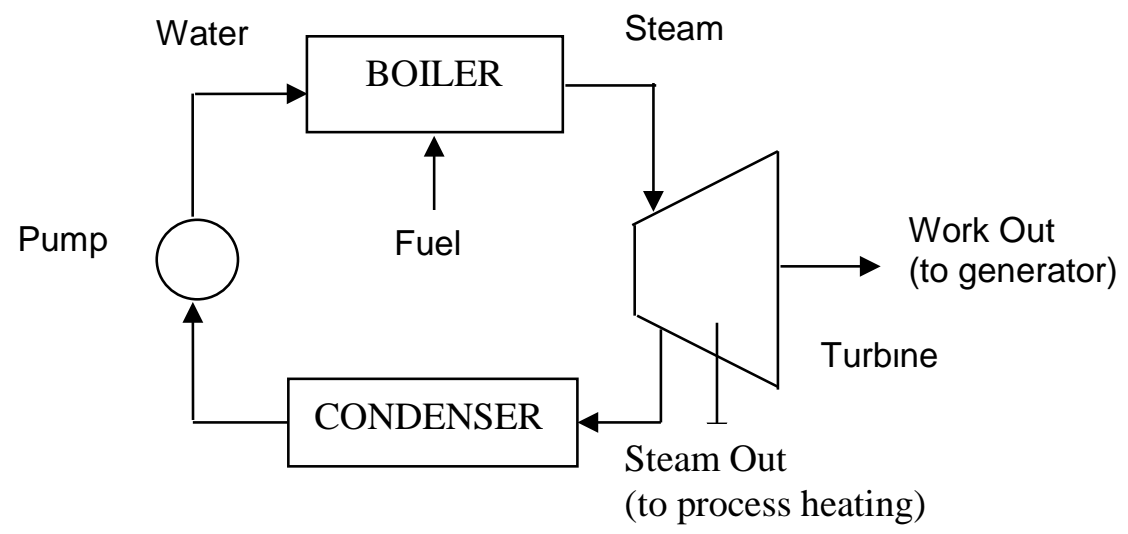

Figure 15. The Steam Turbine Cycle 
Emissions created in the operation of steam turbines are generated in the boiler, where the fuel is combusted. Because the working fluid in the turbine is steam, and not gas, there is no harmful exhaust from the turbine, but boiler emissions are subject to regulations and may require emissions controls.

\subsubsection{Emission Controls}

Control of $\mathrm{NO}_{\mathrm{x}}$ is one of the greatest environmental concerns, and emission regulations can be strict in certain areas. Selective catalytic or non-catalytic reduction can be employed after the fuel is combusted to reduce $\mathrm{NO}_{\mathrm{x}}$ emissions. In addition, low excess air firing, low nitrogen fuel oil, water or steam injection, and flue gas recirculation can all work to bring down the boiler $\mathrm{NO}_{\mathrm{x}}$ levels. The best choice will depend on local air pollution statutes, the boiler's characteristics, and the fuel that is used.

Sulfur compounds, or $\mathrm{SO}_{\mathrm{x}}$, are also a major concern for boilers using fuels other than natural gas. Reduction methods include using low sulfur fuel (tire-derived fuel and wood fuels can produce less sulfur than coal) and desulfurizing the fuel and/or flue gas. Dispersion methods, which use a tall stack to release the exhaust gas higher into the atmosphere, also help to reduce the harmful effects of sulfur emissions.

Carbon monoxide (CO) is another concern, but most modern boilers are designed to limit the amount of $\mathrm{CO}$ produced in the combustion process. Proper burner maintenance should prevent $\mathrm{CO}$ from reaching undesirable levels, but $\mathrm{CO}$ levels can be a concern with biomass boilers. Techniques for reducing $\mathrm{CO}$ emissions can increase $\mathrm{NO}_{\mathrm{x}}$ levels, and thus controlling these two emissions can be a balancing act. ${ }^{88}$ Volatile organic compounds (VOCs), hydrocarbons, and particulate matter are also potential emission problems. Like carbon monoxide, proper burner and boiler maintenance should keep these emissions at acceptable levels.

\subsubsection{Efficiency}

Modern steam turbine power plants have electric efficiencies of between 30 and 40 percent. Smaller turbines have a harder time reaching these efficiencies, as well as turbines fueled by biomass boilers (biomass boiler efficiencies can be considerably less than traditional fossil fuel boilers). For extraction turbines and back-pressure turbines that utilize a large amount of steam for process heating, electric efficiencies of 5-20 percent are more common for steam turbine-boiler systems. The boiler's thermal efficiency, typically maxing out at 75-80 percent for biomass boilers, is the upper limit for total CHP efficiency. Chemical deposits and corrosion in the boiler can bring the efficiency down over time, but this can be countered with regular cleaning and maintenance.

\subsubsection{Federal ITC Applicability}

CHP steam turbines using opportunity fuels can potentially qualify for the Federal Investment Tax Credit (ITC), which can provide a tax credit of 10 percent of the CHP system's total installation cost. ${ }^{89}$

\footnotetext{
${ }^{88}$ Revised Control Technology Review for Carbon Monoxide Emissions for the Biomass-Fired Boiler, We Energies Biomass Energy Project, September 2010.

${ }^{89}$ United States Clean Heat \& Power Association, CHP Investment Tax Credit and Related Provisions of the Emergency Economic Stabilization Act of 2008.
} 
However, there are some caveats to credit applicability that could potentially exclude steam turbine CHP systems.

1. CHP Systems must have a total CHP efficiency of 60 percent or higher - for most extraction turbine systems, the CHP efficiency is expected to be lower than 50 percent.

2. At least 20 percent of the usable energy must be in the form of electricity - this is an issue for most back-pressure turbines, who generate relatively little electricity compared to the steam that is produced.

For some potential CHP installations, a back-pressure steam turbine system with 5-10 percent electric efficiency and 60-75 percent CHP efficiency would not qualify for the ITC. Out of these ranges, the only system that would meet the qualifications is a system with 10 percent electric efficiency and 60 percent overall CHP efficiency, as exactly 20 percent of the useable energy would be in the form of electricity. Although the system could potentially be designed with a CHP efficiency over 60 percent, only one with exactly 60 percent would qualify for the ITC based on the current rules. This is the back-pressure system that will be modeled later in the economic market assessment.

\subsubsection{Equipment Costs}

Compared to combustion turbines and reciprocating engines, steam turbine-based CHP is more expensive to obtain and operate, largely due to costs associated with the boiler. The cost per kilowatt decreases significantly as the boilers and turbines get larger, making large industrial facilities the most ideal locations. However, when working with a no-cost or relatively inexpensive fuel source, smaller steam turbine systems could still be economical in some situations. Also, unless gasifiers are employed, steam turbine boiler systems are the only current technology that can effectively utilize solid fuels.

In the 2006 report, estimated capital and maintenance costs for biomass boilers were lower, especially for smaller systems. Since then, material costs have increased and costs for biomass fuel preparation equipment are better-understood, and significantly higher than previously estimated. As a result, estimated costs for boiler-steam turbine systems have risen across the board. In 2010, new biomass power generation units were generally assumed to cost about $\$ 4,500 / \mathrm{kW}$, nearly twice as much as the $\$ 2,500 / \mathrm{kW}$ rule of thumb that was used in 2006. ${ }^{90}$ Today, most power-only (condensing turbine) biomass steam turbine systems should total between $\$ 3,000 / \mathrm{kW}$ and $\$ 5,000 / \mathrm{kW}$ in installed costs. However, since back-pressure steam turbines produce small amounts of electricity relative to the amount of steam produced in the boiler, smaller back-pressure units running on biomass fuels can surpass $\$ 10,000 / \mathrm{kW}$ when boiler costs are included and costs are expressed on a per-kW basis.

\subsubsection{Solid Fuels}

For solid-fueled boilers, fuels are typically dried, processed to meet sizing specifications, and combusted to generate heat and produce steam. However, there are several different types of boilers that can be incorporated, some better suited for alternative fuels than others. Pulverized coal boilers are some of the most common used for large-scale power generation, but it is difficult for these systems to incorporate

\footnotetext{
${ }^{90}$ Biomass Technology Review, Prepared by McHale \& Associates, Inc, Prepared for Biomass Power Association, October 21, 2010.
} 
other types of fuel. Fluidized bed boilers provide the most flexibility in terms of feedstocks, and they have been commonly employed in wood waste, tire-derived fuel and petroleum coke applications.

Solid biomass fuels (wood and wood waste) have relatively low heating values compared to coal and may contain some impurities. Generally, either circulating fluidized bed or moving grate boilers (stokers) are used with wood fuels, and these types of boilers generally cost the same to install regardless of fuel type. However, biomass fuels can require special preparation yards to dry the fuel, remove any undesirable components, process the fuel into chips, and prepare it for combustion. Prep yard costs can be nearly as high as boiler installation costs for smaller systems.

Tire-derived fuel, unlike wood fuels, has slightly better heat content than coal, with similar combustion characteristics. If shredded and processed adequately, TDF can be combusted in most coal-fired boilers with little to no necessary modifications. However, many TDF grades have incomplete removal of the metal wires embedded in the tire chips, which can cause problems with the boiler and increase maintenance costs. Also, fuel handling and feeding systems would need to be adjusted, and beneficial use of ash could become compromised.

\subsubsection{Gaseous Fuels}

Gaseous opportunity fuels can also be combusted in a boiler steam turbine system. The costs for gaseous fueled boilers are comparable to the costs of solid-fuel stoker boilers, with minimal modifications required for natural gas boilers to utilize medium-Btu biogas fuels. With ADG and LFG, however, pretreatment equipment may be required to rid the gases of potentially harmful particulates such as siloxanes and hydrogen sulfide. Pretreatment equipment costs are expected to range from $\$ 500 / \mathrm{kW}$ to $\$ 1,000 / \mathrm{kW}$ for most condensing turbines, with higher per-kW costs for extraction and back-pressure turbines. Overall, a steam turbine system designed to run on medium-Btu fuels should not cost significantly more than the natural gas alternative, aside from the additional pretreatment costs.

However, for power generation purposes, direct-fired prime movers like gas turbines and reciprocating engines are far more economical than installing a boiler-steam turbine system. For this same reason, even steam turbine generators fueled by natural gas are rare. To date, whenever gaseous opportunity fuels have been used in boilers, it has been strictly for heating applications, not power generation. Because there does not appear to be a market for boiler-steam turbine systems using gaseous fuels, they will not be considered further in this report.

\subsubsection{Installed Equipment Costs}

The cost to install a generic steam turbine with an existing boiler typically ranges from $\$ 400$ to $\$ 800$ per $\mathrm{kW} .{ }^{91}$ However, these costs do not include fuel preparation or boiler equipment, which are multi-million dollar investments. For a relatively small biomass boiler, capable of supplying enough steam to continuously operate a $500 \mathrm{~kW}$ steam generator, estimated installed costs can range from \$2-\$3 million for a stoker boiler to up to $\$ 7$ million for a fluidized bed system. ${ }^{92}$ This translates to a minimum of

\footnotetext{
${ }^{91}$ Biomass Combined Heat and Power Catalog of Technologies, EPA Combined Heat and Power Partnership, September 2007.

${ }^{92}$ Ibid.
} 
$\$ 4,000-\$ 6,000$ per $\mathrm{kW}$ for the smallest stoker boiler systems. With larger boiler sizes, per-unit capital costs can typically be cut in half, down to about $\$ 2,000 / \mathrm{kW}$ for the least-expensive units. For the purposes of this project, only the lower-cost stoker boiler systems will be considered for solid fuels.

When measuring boiler-steam turbine costs on a per $\mathrm{kW}$ basis, one must consider how much of the steam is being converted to electricity, and how much is being used for heating. Biomass boiler steam turbine systems generally cost less than $\$ 5,000 / \mathrm{kW}$ with condensing turbines and electric efficiencies of about 30 percent. However, installed costs for an extraction turbine system with a 15-20 percent electric efficiency could reach $\$ 8,000 / \mathrm{kW}$ as less electricity is being produced. Similarly, per-kW costs would increase significantly for a back-pressure turbine system with only a 5-10 percent electric efficiency, potentially surpassing $\$ 10,000 / \mathrm{kW}$. As the electric efficiency is lowered, however, the CHP efficiency (and amount of steam available for heating) increases, so some industrial sites with high thermal demand could potentially benefit. In addition, CHP systems with total efficiencies over 60 percent, with at least 20 percent of their usable energy in the form of electricity, can qualify for the Federal CHP Investment Tax Credit, which provides credit for 10 percent of the CHP capital investment. ${ }^{93}$ Table 5 shows the estimated installed costs for the various types of boiler/steam turbine systems on a per-kW basis, before including any potential tax credits.

Table 5. Estimated Total Installed Costs (per kW) for Boiler/Steam Turbine Systems

\begin{tabular}{|l|c|c|c|}
\hline \multirow{2}{*}{ Opportunity Fuel } & \multicolumn{3}{|c|}{ Installed Cost $\mathbf{( \$ \mathbf { k W } )}$} \\
\cline { 2 - 4 } & $\begin{array}{l}\text { Condensing Turbine (30\% } \\
\text { electric efficiency, no heat } \\
\text { recovery) }\end{array}$ & $\begin{array}{l}\text { Extraction Turbine (15- } \\
\text { 20\% electric, 45-60\% } \\
\text { CHP efficiency) }\end{array}$ & $\begin{array}{l}\text { Back-Pressure Turbine } \\
\text { (5-10\% electric, 60-75\% } \\
\text { CHP efficiency) }\end{array}$ \\
\hline Solid Biomass & $\$ 2,500-\$ 5,000$ & $\$ 4,000-\$ 8,000$ & $\$ 5,500-\$ 12,000+$ \\
\hline TDF & $\$ 2,000-\$ 4,500$ & $\$ 2,800-\$ 6,600$ & $\$ 4,000-\$ 10,000+$ \\
\hline
\end{tabular}

Source: Biomass Combined Heat and Power Catalog of Technologies, U.S. Environmental Protection Agency Combined Heat and Power Partnership, 2007, costs for biomass stoker boiler steam turbine systems with reduced prep yard costs for TDF fuels. Costs have been increased by 25-30 percent to represent 2013 dollars, and to reflect some more recent information on biomass power plant installation costs, such as the Biomass Technology Review prepared by McHale \& Associates (Biomass Technology Review, Prepared by McHale \& Associates, Inc., Prepared for Biomass Power Association, October 21, 2010).

\subsubsection{Maintenance Costs and Issues with Opportunity Fuels}

For steam turbines with coal or natural gas-fired boilers, maintenance costs (including the boiler) tend to range from $\$ 0.01$ to $\$ 0.03$ per $\mathrm{kWh}$ for condensing turbine systems, with coal boilers requiring considerably more upkeep. The maintenance costs for steam turbines themselves are fairly low, at about $\$ 0.005$ per $\mathrm{kWh}$ for systems larger than $2 \mathrm{MW}$, and for condensing turbine systems, at a minimum the boiler would double that cost to $\$ 0.01$ per kWh. ${ }^{94}$ However, back-pressure steam turbines that would be used for CHP applications produce a small amount of power relative to the fuel that is being combusted in

${ }^{93}$ United States Clean Heat \& Power Association, CHP Investment Tax Credit and Related Provisions of the Emergency Economic Stabilization Act of 2008.

${ }^{94}$ Catalog of CHP Technologies: Technology Characterization: Steam Turbines, U.S. Environmental Protection Agency Combined Heat and Power Partnership, prepared by Energy and Environmental Analysis, December 2008. 
the boiler, so boiler maintenance is greatly increased on a per-kWh basis. Additionally, smaller boiler/steam turbine systems, as would be used in many potential CHP projects, require relatively more maintenance than larger systems. For back-pressure steam turbine systems, maintenance costs can range from \$0.02 per kWh for units larger than $10 \mathrm{MW}$ to over $\$ 0.10$ per $\mathrm{kWh}$ for small $500 \mathrm{~kW}$ units. Of course, these maintenance costs can be slightly misleading because they allocate all of the boiler maintenance to the electric power generated by the turbine. As with equipment costs, maintenance costs per kWh tend to decrease with economies of scale as the system size grows.

For a steam turbine system running on woody biomass fuels, the operation and maintenance requirements for the boiler and fuel preparation yard are significant, due mainly to excessive tar buildup in the boiler and high fuel handling and preparation costs. It is estimated that maintenance for the total biomass steam turbine system ranges from $\$ 0.015$ to $\$ 0.05$ per $\mathrm{kWh}$ for condensing turbines, or $\$ 0.03$ to $\$ 0.15$ per $\mathrm{kWh}$ for back pressure turbines. These ranges were confirmed with maintenance cost estimates in the Biomass CHP Catalog of Technologies ${ }^{95}$ and the Biomass Technology Review by McHale and Associates ${ }^{96}$. Maintenance costs for extraction turbine systems should fall in between the costs for condensing turbines and back pressure turbines.

Depending on the level of wire removal, the size of the chips, and the combustion temperature, tirederived fuel may or may not require as much maintenance as wood fuels. In general, boiler maintenance costs are expected to increase by about 50 percent compared to coal, mainly because of more frequent cleaning and ash disposal issues caused by metal scraps embedded in the tires. The total costs for TDF boiler steam turbine system maintenance are expected to increase only slightly compared to coal, estimated at $\$ 0.01$ to $\$ 0.04$ per $\mathrm{kWh}$ for condensing turbines, or $\$ 0.02$ to $\$ 0.12$ per $\mathrm{kWh}$ for back pressure turbines.

\subsubsection{Applications for Steam Turbines}

Steam turbines could be suitable for a number of CHP applications, particularly in the industrial sector, but they are most commonly used in large coal power plants and combined cycle turbines, not in combined heat and power configurations. Boiler-steam turbine systems are generally more expensive to install than reciprocating engines and combustion turbines, but they can utilize solid fuels and provide valuable steam for industrial heating applications as well as hot water and space heating. However, they require large footprints and are generally not suited for most commercial facilities other than universities and hospitals. Also, licensed boiler operators are sometimes required to maintain the boiler system, and a constant source of makeup water is needed. However, steam turbines could make a good choice for CHP at industrial facilities that demand steam for process heating, especially when on-site waste fuels can be utilized. For solid waste fuels, steam turbine systems are often the only choice available for power generation.

\footnotetext{
${ }^{95}$ Biomass Combined Heat and Power Catalog of Technologies, EPA Combined Heat and Power Partnership, September 2007.

${ }^{96}$ Biomass Technology Review, Prepared by McHale \& Associates, Inc., Prepared for Biomass Power Association, October 21, 2010.
} 


\subsection{COMBUSTION TURBINES}

Combustion turbines, also known as gas turbines, have been used for power generation for decades. They range in size from simple cycle units starting at about $1 \mathrm{MW}$, up to several hundred megawatts when configured as a combined cycle power plant. Units from 1-15 MW are generally referred to as industrial turbines, differentiating them from larger utility grade turbines and smaller microturbines. Units smaller than 1 MW are on the market, but very few have been installed in the U.S. since their price is high and electrical efficiencies are relatively low compared to reciprocating engines. Traditionally, turbine applications have been limited by lower electrical efficiencies to combined heat and power uses at industrial and institutional settings and peaking units for electric utilities. However, improvements in electrical efficiency have been made and combustion turbines are now being used for intermediate and baseload power, as well as a growing number of applications with medium-Btu opportunity fuels.

\subsubsection{Operation}

Historically, industrial turbines have been developed as aero derivatives using jet propulsion engines as a design base. Some, however, have been designed specifically for stationary power generation or for compression applications in the oil and gas industries. In a combustion turbine, air is compressed, mixed with a gaseous or liquid fuel and ignited. The combustion products are expanded directly through the blades in a turbine to drive an electric generator. The compressor and turbine usually have multiple stages and axial blading. This differentiates them from smaller microturbines that have radial blades and are single staged.

Unfortunately, the intricacy of blade design and spacing with combustion turbines means that many existing natural gas units cannot be feasibly retrofit to run on $100 \%$ landfill gas or digester gas. In early landfill gas energy projects, some retrofit turbines were attempted with poor results, allowing retrofit reciprocating engines to dominate the medium-Btu gas market for many years. However, turbine manufacturers have begun to produce models which perform well with medium-Btu fuels. In 2004, Solar Turbines began a development program with the Calabasas Landfill in Los Angeles, engineering modifications for the low-emissions Mercury 50 turbine (4.6 MW) to run on landfill gas. In 2010, three of the modified Mercury 50 turbines began operating at the Calabasas Landfill in Los Angeles, and results to date have been positive. ${ }^{97}$

Several Mercury 50 biogas installations have been installed or are currently underway as a result of the development process, including the large Blue Plains Wastewater Treatment Plant in Washington, DC. Other Solar Turbine designs have also successfully been modified to work with $100 \%$ biogas fuels, so it is possible that combustion turbines will begin to play a more prominent role in large anaerobic digester gas and landfill gas CHP installations.

Combined heat and power is readily achieved with combustion turbines, since their exhaust gas is extremely hot (about $1000^{\circ} \mathrm{F}$ ). The exhaust can be used to produce steam in a heat recovery steam generator (HRSG). An HRSG is essentially a large heat exchanger that transfers the exhaust heat to water and produces steam. The exhaust gas is cooled to about $300^{\circ} \mathrm{F}$ - lower temperatures could cause condensation of the exhaust gases that could lead to corrosion, and the steam is heated to a high temperature and pressure. Combined cycle units (where steam from the HRSG is used to power a steam

\footnotetext{
${ }^{97}$ Solar Turbines, Calabasas Landfill Gas to Energy Project (Press Release), 2011.
} 
turbine) are commonly used by utilities and large industrial operations due to their high efficiency and power output. In CHP sized units, the steam produced in the HRSG can be used for industrial processes or other heating applications. For an illustration of the combustion turbine cycle, see Figure 16. The intercooler shown in the figure is generally reserved for larger units that can economically incorporate this improvement.

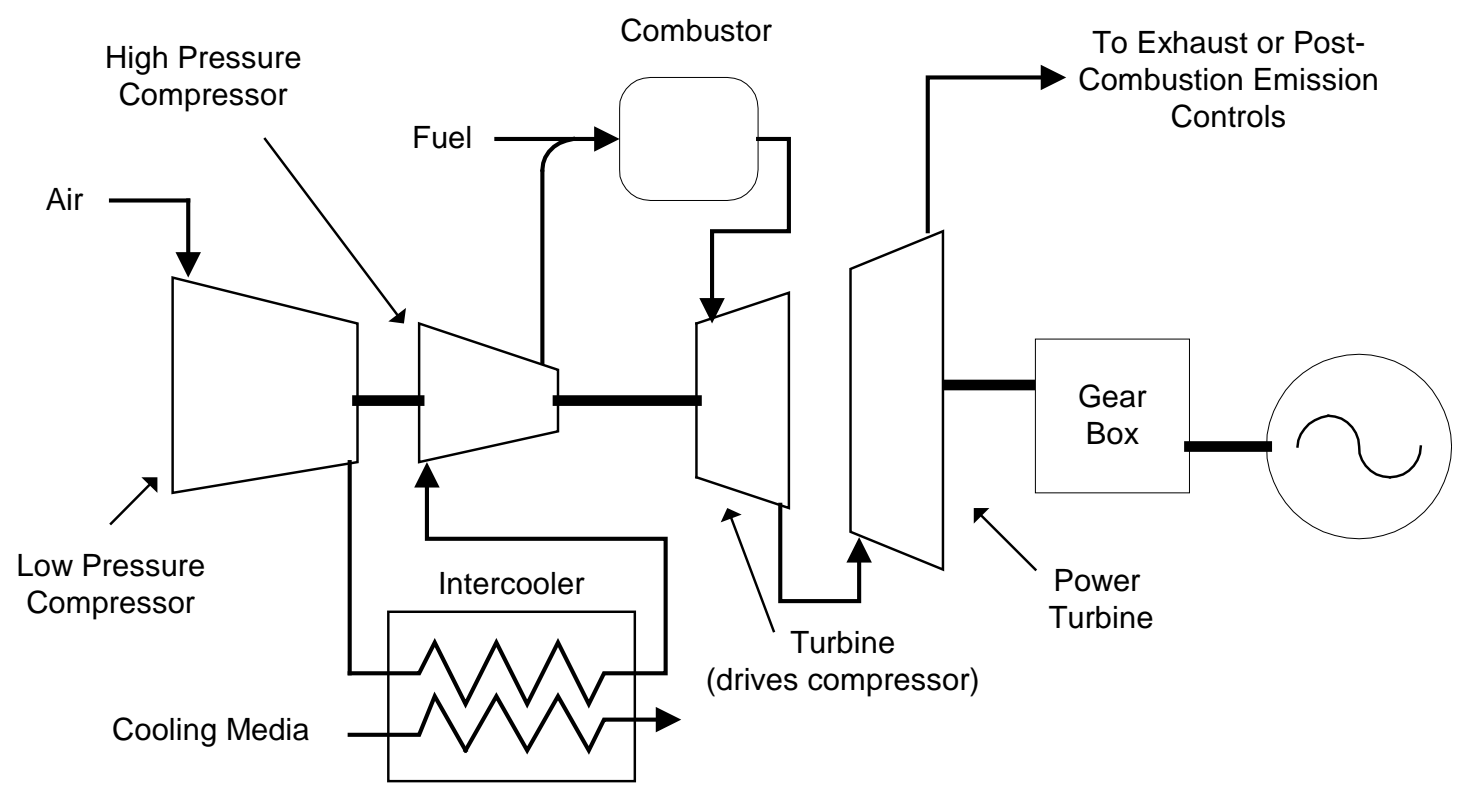

Figure 16. Combustion Turbine System (with intercooler)

\subsubsection{Emission Controls}

Given that combustion takes place outside of the turbine area (unlike reciprocating engines, where combustion takes place inside the cylinder), turbines have more flexibility than engines in reducing $\mathrm{NO}_{\mathrm{x}}$ emissions. $\mathrm{NO}_{\mathrm{x}}$ emissions from uncontrolled natural gas turbines range from 75 to over $150 \mathrm{ppm}$, due to high combustion temperatures. Emissions control of combustion turbines can be accomplished by injecting water or steam to reduce the combustion temperature and reduce $\mathrm{NO}_{\mathrm{x}}$ levels down to 25-45 ppm. In addition, these methods increase power production and can increase the system efficiency. While these means have proven effective in limiting $\mathrm{NO}_{\mathrm{x}}$ emissions, the availability of water supply and space for storage tanks are constraints for some applications. Some turbines (especially those using lowBtu fuels) utilize diffusion flame combustors, which inject small amounts of air into the fuel prior to combustion, mixing the gases with turbulent diffusion and bringing $\mathrm{NO}_{\mathrm{x}}$ levels down to $25-35 \mathrm{ppm}$. In many states, these measures are deemed adequate to meet $\mathrm{NO}_{\mathrm{x}}$ regulations.

Dry Low $\mathrm{NO}_{\mathrm{x}}$ (DLN), conceptually similar to lean burn technology for reciprocating engines, creates a lean, homogeneous mixture of air and fuel that then enters the combustor. This minimizes hot spots and reduces the combustion temperature, which leads to lower $\mathrm{NO}_{\mathrm{x}}$ levels. DLN has become the standard for $\mathrm{NO}_{\mathrm{x}}$ control in natural gas combustion turbines, but it is not easily used with low-Btu fuels. 
Although combustion turbines tend to generate lower emissions than reciprocating engines, in many U.S. states units must be installed with additional control technologies to further reduce $\mathrm{NO}_{\mathrm{x}}$ emissions. Selective catalytic reduction is the primary option for further reduction of $\mathrm{NO}_{\mathrm{x}}$. Catalytic combustors, one emerging $\mathrm{NO}_{\mathrm{x}}$ control option, fully convert the input fuel and air without the use of a flame. Since in a traditional combustor the majority of $\mathrm{NO}_{\mathrm{x}}$ is produced in the high-temperature region near the flame, catalytic systems substantially reduce these emissions.

\subsubsection{Efficiency}

Electrical efficiencies of natural gas-fueled simple cycle combustion turbines in the 1-50 MW range can fall anywhere between 28 and 39 percent (using the higher heating value). Smaller applications with medium-Btu fuels tend to stay on the lower side of these ranges. More durable and temperature resistant materials (ceramics, single-crystal superalloys, and directionally solidified material) or advanced cooling schemes (transpiration and vortex) are needed for first stage turbine blades and combustors in order to increase the operating temperature/compression ratio and, therefore, efficiencies of turbines. These developments will also result in less down-time and lower-cost maintenance.

Efficiency may be improved through the use of recuperators (air-to-air heat exchangers that use exhaust gases to preheat the compressed combustor inlet air). Although recuperation is not commonly employed for turbines in the $>1 \mathrm{MW}$ size range, Solar Turbines now offers its Mercury 50, a 4.9 MW recuperated unit with a reported electric efficiency of 38.5 percent running on natural gas. However, most combustion turbines are limited to electric efficiencies of around 36 percent when using medium-Btu fuels like ADG and LFG. CHP efficiencies typically top out around 70 percent with medium-Btu fuels.

Intercooling (cooling air between two or more compression stages) can increase efficiency by reducing air compression power requirements, and produces lower temperature air for better cooling of turbine parts, but this is unlikely for most CHP units. Ambient effects on efficiency are also important since peak turbine use is normally during high temperature periods when turbine maximum output is lowest. Current methods to lessen the effects of ambient temperature include evaporative, mechanical, or adsorption inlet air chillers, steam injection into the combustor for higher mass flow or $\mathrm{NO}_{\mathrm{x}}$ control, and compressed air storage/injection.

\subsubsection{Equipment Costs and Modifications for Opportunity Fuels}

In the 2006 report, combustion turbine costs for ADG/LFG were estimated much higher, and recent advancements in medium-Btu turbine designs have led to lower installed costs. However, pretreatment costs for ADG/LFG were underestimated in 2006, and have been raised significantly for this analysis.

Combustion turbines tend to cost significantly less than most steam turbine systems on a per-kilowatt basis, primarily because steam turbines require a separate boiler. The installed cost of a natural gas CHP combustion turbine ranges from $\$ 1,000$ to $\$ 3,000$ per $\mathrm{kW}$, depending on the unit's size and design. ${ }^{98}$ Combined cycle turbines that use a heat recovery steam generator and a secondary steam turbine typically cost a few hundred dollars more per $\mathrm{kW}$, but they are generally limited to large utility-scale systems, and are not considered in the economic analysis.

${ }^{98}$ Catalog of CHP Technologies: Technology Characterization: Gas Turbines, U.S. Environmental Protection Agency Combined Heat and Power Partnership, prepared by Energy and Environmental Analysis, December 2008. 
Natural gas combustion turbine designs can be modified to utilize medium-Btu gases with larger nozzles and combustion areas, heavy-duty compressors, and larger intake manifolds. These adjustments are made to accommodate the higher flow rates that are necessary for gases with lower heat content. Since the gas must be compressed heavily, up to 10 percent of the power generated from the turbine may need to be applied to the compressor. Gas collected from landfills and digesters does not always flow in a continuous stream, which could cause blade stalling and other issues for the turbine if the flow is not smoothed out or blended with a more steady fuel source. Despite all of these potential drawbacks, combustion turbines could play an important role in opportunity development, especially in the 5-50 MW size range. New turbines such as the Mercury 50, a 4.8 MW turbine that works well with medium-Btu fuels, are able to produce heat and power more efficiently than many reciprocating engines using ADG or LFG. In 2010, the Mercury 50 was estimated to cost $\$ 1,800 / \mathrm{kW}$ for a landfill gas application, including the compressor and pretreatment equipment. The engineering consulting firm CDM reported costs of \$2,200-\$2,500 per kW for similarly-sized ADG combustion turbines at Texas wastewater treatment plants in $2005 .{ }^{99}$

Because of all the modifications required, existing natural gas turbines cannot easily be retrofitted to run on medium-Btu fuels. Combustion turbines designed for medium-Btu gases tend to cost slightly more than natural gas turbines ( $\$ 1,000-\$ 3,000 / \mathrm{kW}$ for CHP units) on a per-kW basis. Also, pretreatment equipment is necessary for most ADG and LFG combustion turbine projects, complete with siloxane and hydrogen sulfide removal. For large combustion turbine installations, total pretreatment costs of about $\$ 500 / \mathrm{kW}$ can be expected, but over $\$ 1,000 / \mathrm{kW}$ can be required for larger units. Total costs for ADG or LFG fueled CHP combustion turbines, including pretreatment, are estimated at $\$ 1,500-\$ 4,000 / \mathrm{kW}$. For ADG, if an anaerobic digester is to be installed, additional capital costs averaging about $\$ 2,000 / \mathrm{kW}$ are expected.

When properly treated, coalbed methane can be used in existing natural gas combustion turbines, since the fuel's properties are so similar to natural gas. The equipment and maintenance costs for coalbed methane are assumed to be similar to costs associated with natural gas. Pretreatment equipment is required to remove harmful particulates, but not nearly on the same level as ADG/LFG - additional costs of $\$ 100-\$ 200 / \mathrm{kW}$ are likely.

Another option for utilizing gaseous opportunity fuels with combustion turbines is to incorporate them into a duct firing process. With duct firing, the exhaust gas of the turbine, along with additional fuel, are combusted in order to increase steam generation. This can be done with existing or new combustion turbines, and it could be an inexpensive source of additional thermal energy for those located close to ADG, LFG, or coalbed methane resources. Duct firing does not require the fuels to be compressed, and does not require as much fuel clean-up or pretreatment equipment compared to using ADG or LFG as the primary fuel.

\footnotetext{
${ }^{99}$ Opportunities for and Benefits of Combined Heat and Power at Wastewater Treatment Facilities. US EPA Combined Heat and Power Partnership. Updated January 2011.
} 


\subsubsection{Maintenance Costs and Issues with Opportunity Fuels}

Overall maintenance for combustion turbines can range from $\$ 0.005$ to $\$ 0.012$ per $\mathrm{kWh}$ for natural gas units. ${ }^{100}$ When a gas turbine is operating on ADG or LFG, increased cleaning and more frequent maintenance check-ups are typically required, along with additional maintenance for pretreatment equipment. Overall, maintenance costs for gas turbines using ADG or LFG are expected to range from 1 to 2.5 cents per $\mathrm{kWh}$, averaging about $\$ 0.016$ per kWh for LFG units operating year-round. ${ }^{101}$ However, maintenance costs vary with prime mover size, so while larger units can reach as low as a penny per kWh, smaller units can require up to two and a half cents. An anaerobic digester can add \$0.001-\$0.003 per kWh in maintenance costs. For coalbed methane, the low natural gas maintenance costs of \$0.005-\$0.011 per $\mathrm{kWh}$ are expected to be maintained, with an additional \$0.001-\$0.002 per kWh for fuel pretreatment and compression equipment.

The estimated installed costs, maintenance costs, and efficiencies for combustion turbines using gaseous opportunity fuels are presented in Table 6.

Table 6. Price and Performance Parameters for CHP Combustion Turbines (Full Pretreatment)

\begin{tabular}{|c|c|c|c|c|}
\hline Opportunity Fuel & $\begin{array}{c}\text { Installed Cost } \\
(\$ / \mathbf{k W})\end{array}$ & $\begin{array}{l}\text { Maintenance } \\
\text { Cost }(\$ / \mathbf{k W h})\end{array}$ & $\begin{array}{c}\text { Electric } \\
\text { Efficiency } \\
\text { (HHV) }\end{array}$ & $\begin{array}{c}\text { CHP } \\
\text { Efficiency } \\
\text { (HHV) }\end{array}$ \\
\hline Anaerobic Digester Gas & $\$ 1,500-\$ 4,000$ & $\$ 0.01-\$ 0.025$ & $28-35 \%$ & $65-70 \%$ \\
\hline Landfill Gas & $\$ 1,500-\$ 4,000$ & $\$ 0.01-\$ 0.025$ & $28-35 \%$ & $65-70 \%$ \\
\hline Coalbed Methane & $\$ 1,000-\$ 3,000$ & $\$ 0.006-\$ 0.014$ & $30-38 \%$ & $68-75 \%$ \\
\hline
\end{tabular}

\subsubsection{Applications for Combustion Turbines}

Combustion turbine CHP applications are typically only found at larger industrial, municipal or institutional facilities. Some of these sites use combustion turbines in combined-cycle configurations, where the exhaust gas is used to produce steam for a secondary steam turbine. In both cases, considerable waste heat can be produced for CHP applications, but only simple-cycle turbines will be considered for this analysis. Coalbed methane generally performs just as well as natural gas, so it is an ideal opportunity fuel for combustion turbines. Medium-Btu gases like ADG and LFG are not very well suited well for retrofit combustion turbine applications, although Solar Turbines has created several smaller units like the recent Mercury 50 that can handle these fuels with relatively few problems. Overall, combustion turbines are one of the most prominent CHP technologies, and should be considered for all gaseous opportunity fuel applications that are large enough to support them.

\footnotetext{
${ }^{100}$ Catalog of CHP Technologies: Technology Characterization: Gas Turbines, U.S. Environmental Protection Agency Combined Heat and Power Partnership, prepared by Energy and Environmental Analysis, December 2008. ${ }^{101}$ Project Development Handbook, United States Environmental Protection Agency, Landfill Methane Outreach Program, April 2011, http://www.epa.gov/lmop/publications-tools/handbook.html
} 


\subsection{RECIPROCATING ENGINES}

Of all the electricity-generating technologies, reciprocating engines have been around the longest. Both Otto (spark ignition) and Diesel cycle (compression ignition) engines have gained widespread acceptance in almost every sector of the economy. Reciprocating engines have been utilized worldwide for applications ranging from fractional horsepower units to large $60 \mathrm{MW}$ baseload electric power plants. Otto cycle reciprocating engines, normally fueled by natural gas, can be configured to operate with gaseous opportunity fuels. Engines have become common at landfills and wastewater treatment plants, burning the medium-Btu waste gases for combined heat and power applications. Reciprocating engines are also commonly used in coalbed methane projects.

\subsubsection{Operation}

Most engines used for power generation are four-stroke and operate in four cycles (intake, compression, combustion, and exhaust). The four-stroke process begins with fuel and air being mixed, usually before introduction into the combustion cylinder for spark ignited units (see Figure 17). In turbocharged applications, the air is compressed before mixing with fuel. The fuel/air mixture is introduced into a combustion cylinder that is closed at one end and contains a moveable piston. The mixture is then compressed as the piston moves toward the top of the cylinder. The pressure of the hot, combusted gases drives the piston down the cylinder. Energy in the moving piston is translated to rotational energy by a crankshaft. As the piston reaches the bottom of its stroke, the exhaust valve opens and the exhaust is expelled from the cylinder by the rising piston.

Reciprocating engine CHP systems can be designed to produce steam, hot water, or hot air. There are many different possible configurations for heat recovery, and all have their advantages and disadvantages. Standard heat exchangers are typically used to produce hot water and steam. Sometimes, however, ebullient cooling systems are used to produce steam and cool the engine in the process. With ebullient systems, a boiling coolant is circulated through the engine jacket and fed through an air-to-water heat exchanger along with the engine's exhaust. Forced circulation systems, which utilize higher temperature and pressure water in the engine jacket, are sometimes used to produce pressurized steam.

On certain occasions, exhaust gas from the reciprocating engine is used to directly dry certain products such as bricks and ceramics. This is referred to as "dirty drying" because of particulates and other contaminants in the engine's exhaust. The most common method of heat recovery from reciprocating engines, however, remains to be conventional heat exchangers that utilize the engine's hot exhaust gas, jacket water and lube oil to produce hot water and steam. This method is shown in the Figure 17 schematic. 


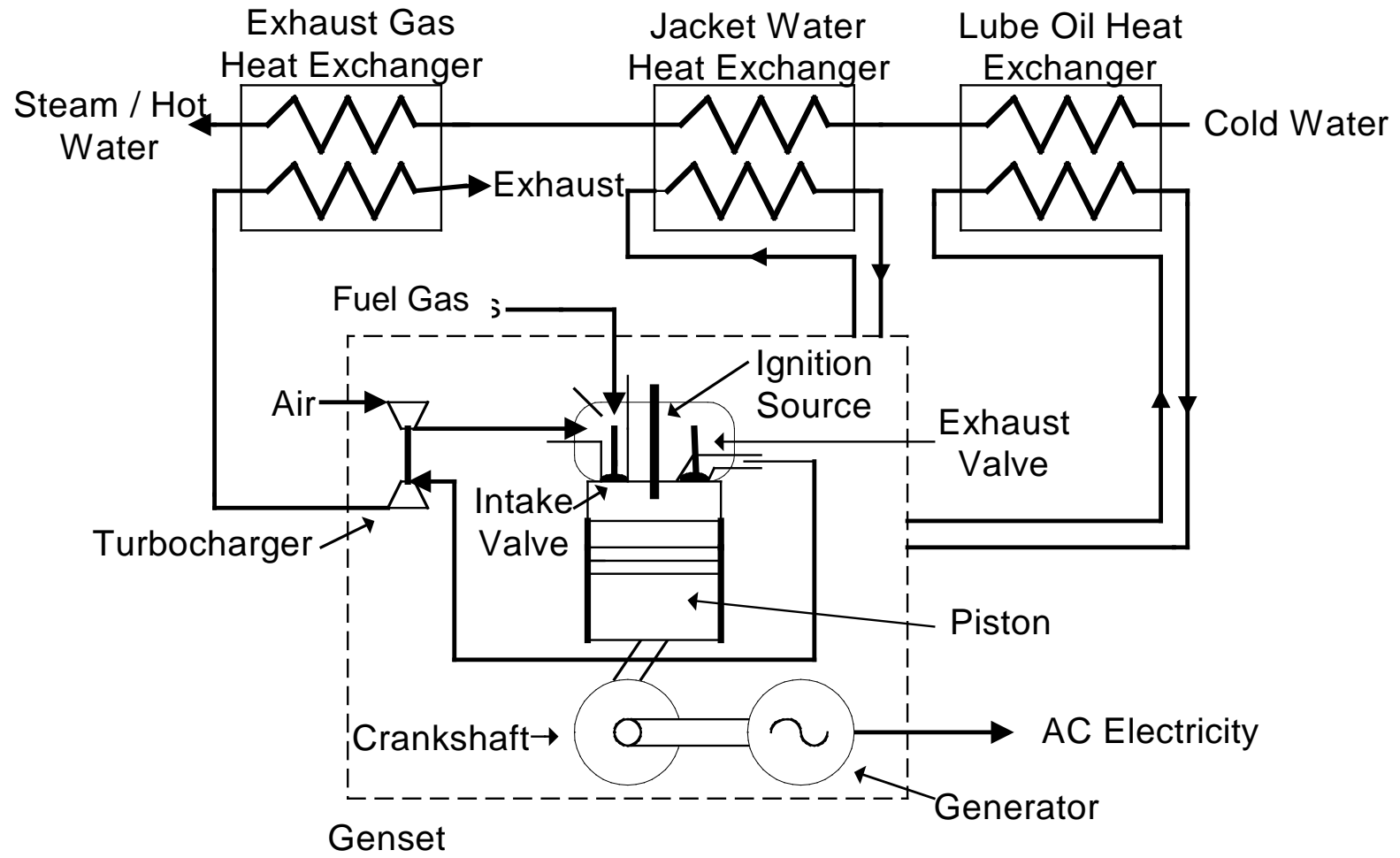

Figure 17. Schematic of an Otto (spark-ignition) Reciprocating Engine with Heat Recovery

\subsubsection{Emission Controls}

The combustion process produces $\mathrm{NO}_{\mathrm{x}}$, carbon monoxide, hydrocarbon, and particulate emissions. Because reciprocating engines combust gas under high pressure, emission control technologies are harder to apply compared to turbines, and in general, more $\mathrm{NO}_{\mathrm{x}}$ is produced. Frequent and thorough maintenance helps reduce emissions, and this is needed even more so for most opportunity fuels. Control technologies like Selective Catalytic Reduction (SCR) and other post-combustion methods are complicated and expensive to implement and maintain. In certain areas with strict environmental regulations, SCR is required for larger reciprocating engines, even when using biogas. This can make it difficult to site units for certain CHP applications. In addition, catalytic controls are hindered by siloxanes and hydrogen sulfide, which are usually found in ADG and LFG. Extensive fuel treatment would be required in order to prevent catalyst poisoning. However, with most engines under $5 \mathrm{MW}$ in size, SCR is typically not required, as lean-burning can bring $\mathrm{NO}_{\mathrm{x}}$ emissions down to acceptable levels.

New emission control methods focus on lean-burning, or using a high air to fuel ratio. Lean-burning improves efficiencies and lowers $\mathrm{NO}_{\mathrm{x}}$ emissions, but it can also lower the power output. This can be compensated for by the incorporation of turbocharging, which increases the power density. Lean-burn technology, however, is generally limited to engines $300 \mathrm{~kW}$ or larger in size. In addition, it is not as effective for fuels with lower heat contents - the amount of excess air that can be used becomes limited, since the fuel-air mixture can easily become too dilute. Still, lean-burn technologies are almost always used in LFG and ADG applications to reduce NOx emissions. Effective turbocharging can increase output when using lean-burn engines with low-Btu fuels. 


\subsubsection{Efficiency}

Electric efficiencies for natural gas reciprocating engines typically fall between 30 and 40 percent, with an overall efficiency of up to 80 percent when CHP is utilized. Small engines running on medium-Btu fuels will have a harder time reaching these numbers, with most ADG and LFG engines topping out around 36 percent electric efficiency, and 75 percent CHP efficiency. Combustion chamber design is important not only to the efficient and complete combustion of fuels but also for the reduction of $\mathrm{NO}_{\mathrm{x}}$ emissions. How and when fuel is injected in the cycle plays an important role in how the fuel is combusted, and thus influences power, efficiency, and emissions. High efficiency engines operate at higher pressure levels that require high-energy spark ignition systems with durable components. Effective turbocharging is key to increasing Brake Mean Effective Pressure, which in turn leads to increased efficiency. Turbocharged engines can achieve greater power density, allowing units to be placed in a smaller area and/or lessen foundation reinforcement requirements. However, turbocharging is not as effective with medium-Btu fuels, so it is typically not used, resulting in lower electric efficiencies.

\subsubsection{Equipment Costs and Modifications for Opportunity Fuels}

Estimated costs for reciprocating engine gensets have become slightly higher since 2006, but estimates for biogas pretreatment costs have increased significantly.

While reciprocating engines have a lower capital cost than most other small power generating technologies, environmental siting, permitting, and other issues can add to installation costs.

Reciprocating engines are most common in the $300 \mathrm{~kW}$ to $5 \mathrm{MW}$ size range, but single units as large as $20 \mathrm{MW}$ do exist in utility applications. The cost to install a natural gas-fueled CHP reciprocating engine typically ranges from $\$ 1,000$ to $\$ 2,200$ per $\mathrm{kW} .{ }^{102}$ As with most prime mover equipment, smaller units fall on the high end of the price spectrum.

Reciprocating engines designed for natural gas have the same issues with medium-Btu fuels as combustion turbines in that they must be modified to accommodate more impurities and lower heat content. These modifications include incorporating pretreatment equipment and adjusting for higher gas flow rates with larger manifolds and modified fuel injectors. The flow rate adjustments tend to increase the cost of medium-Btu engines, resulting in total costs of $\$ 1,100$ to $\$ 2,500$ per $\mathrm{kW}$. Fuel pretreatment equipment for siloxane, $\mathrm{H}_{2} \mathrm{~S}$ and other particulate removal (as well as fuel compression) can cost up to $\$ 2,000 / \mathrm{kW}^{103}$ to install, effectively doubling the cost of small reciprocating engines for ADG and LFG. For larger engines, the incremental cost of pretreatment decreases to about $\$ 600 / \mathrm{kW}$ for large units in the $5 \mathrm{MW}$ range. Total costs for CHP reciprocating engines fueled by ADG or LFG are expected to fall between $\$ 1,800$ and $\$ 5,000$ per $\mathrm{kW}$. Small rich burn engines tend to cost between $\$ 3,000$ and $\$ 5,000$ per

\footnotetext{
${ }^{102}$ Catalog of CHP Technologies: Technology Characterization: Reciprocating Engines, U.S. Environmental Protection Agency Combined Heat and Power Partnership, prepared by Energy and Environmental Analysis, December 2008.

${ }^{103}$ Pretreatment costs of $\$ 2,000 / \mathrm{kW}$ are expected for small $(<60 \mathrm{~kW})$ engines that require complete fuel treatment equipment, including siloxanes removal. For larger engines, installed costs fall to $\$ 600-\$ 1,000 / \mathrm{kW}$. A quote from GE Jenbacher for gas compression and fuel conditioning equipment was $\$ 300,000$ for a $335 \mathrm{~kW}$ system, or just under $\$ 1,000 / \mathrm{kW}$.
} 
$\mathrm{kW}$, while larger lean burn engines average about $\$ 2,500$ per $\mathrm{kW}$, with only the largest systems (> $5 \mathrm{MW}$ ) falling below $\$ 2,000 / \mathrm{kW}^{104}$

Coalbed methane can also power reciprocating engines, with no modifications required and only a slight increase in cost due to pretreatment equipment (\$100-\$300 per $\mathrm{kW})$. As with the other power generating technologies, the performance difference between natural gas and coalbed methane is negligible, and costs should remain about the same. However, gas cleanup equipment will likely add marginally to the capital costs.

\subsubsection{Maintenance Costs and Issues with Opportunity Fuels}

Some maintenance problems associated with reciprocating engines running on medium-Btu fuels are increased wear and tear, more cleaning, and more frequent oil changes. Additional maintenance for fuel pretreatment equipment is also required, and this can be especially high for smaller systems. Generally, maintenance for medium-Btu gas engines with pretreatment equipment costs between 2 and 3 cents per $\mathrm{kWh}^{105}$, although smaller rich-burn units can potentially reach 4 cents/kWh. An additional \$0.001-\$0.003 per kWh can be expected if an anaerobic digester is installed. For coalbed methane, there is little additional maintenance is required compared to natural gas engines, and maintenance costs are expected to range from 1 to 2.2 cents per $\mathrm{kWh}$.

Table 7 provides the price and performance parameters for opportunity-fueled reciprocating engines, including installed costs, maintenance costs, and efficiencies.

Table 7. Price and Performance Parameters for CHP Reciprocating Engines (Full Pretreatment)

\begin{tabular}{|c|c|c|c|c|}
\hline Opportunity Fuel & $\begin{array}{c}\text { Installed Cost } \\
(\$ / \mathbf{k W})\end{array}$ & $\begin{array}{l}\text { Maintenance } \\
\text { Cost (\$/kWh) }\end{array}$ & $\begin{array}{c}\text { Electric } \\
\text { Efficiency } \\
\text { (HHV) }\end{array}$ & $\begin{array}{c}\text { CHP } \\
\text { Efficiency } \\
\text { (HHV) }\end{array}$ \\
\hline Anaerobic Digester Gas & $\$ 1,800-\$ 4,500$ & $\$ 0.02-\$ 0.04$ & $32-36 \%$ & $70-75 \%$ \\
\hline Landfill Gas & $\$ 1,800-\$ 4,500$ & $\$ 0.02-\$ 0.04$ & $32-36 \%$ & $70-75 \%$ \\
\hline Coalbed Methane & $\$ 1,100-\$ 2,500$ & $\$ 0.01-\$ 0.022$ & $35-39 \%$ & $75-80 \%$ \\
\hline
\end{tabular}

\subsubsection{Applications for Reciprocating Engines}

Reciprocating engines are used in a wide variety of applications, and are most often used for backup power (diesel engines). Natural gas models are most commonly used for small CHP operations, particularly in areas with lenient emissions requirements. As for opportunity fuels, reciprocating engines

${ }^{104}$ Opportunities for and Benefits of Combined Heat and Power at Wastewater Treatment Facilities: Market Analysis and Lessons from the Field, United States Environmental Protection Agency, Combined Heat and Power Partnership, October 2011.

${ }^{105}$ Project Development Handbook, United States Environmental Protection Agency, Landfill Methane Outreach Program, April 2011, http://www.epa.gov/lmop/publications-tools/handbook.html 
are easier to retrofit for medium-Btu gases compared to combustion turbines. Engines can be used for smaller projects, which gives them more flexibility, although turbines show some economic advantages for larger applications. Reciprocating engines have been used successfully in many ADG, LFG and coalbed methane power-generating applications, and arguably make the best overall choice for mediumsized projects in areas where emissions are not an issue.

\subsection{MICROTURBINES}

The technology used in microturbines is derived from aircraft auxiliary power systems, diesel engine turbochargers, and automotive designs. A relatively small number of companies have developed units for small-scale distributed power generation in the 30-300 kW size range. Capstone Turbines currently offers $30 \mathrm{~kW}, 65 \mathrm{~kW}$, and $200 \mathrm{~kW}$ microturbines capable of operating on a number of different fuels, including anaerobic digester gas, coalbed methane and landfill gas. They also offer a 1-MW unit comprised of five $200 \mathrm{~kW}$ microturbines. FlexEnergy (formerly Ingersoll Rand) currently offers a $250 \mathrm{~kW}$ model that will also run on opportunity fuels. These microturbine models have been installed in various CHP projects throughout the world, and several projects are currently in the planning process.

\subsubsection{Operation}

Simple microturbines consist of a compressor, combustor, turbine, and generator. The compressors and turbines are typically radial-flow designs, and resemble automotive engine turbochargers. Most designs are single-shaft and use a high-speed permanent magnet generator producing variable voltage, variable frequency alternating current (AC) power. An inverter is employed to produce $60 \mathrm{~Hz}$ AC power. Most microturbine units are designed for continuous-duty operation and are recuperated to obtain competitive electric efficiencies. A typical microturbine system with a recuperator is depicted in Figure 18.

Microturbines do not produce as much recoverable heat as combustion turbines, but they can still be used to produce hot water and steam for CHP applications. Unrecuperated models have a much higher exhaust temperature than recuperated models, but at the sacrifice of electric efficiency and power output. If the microturbine is going to be used extensively for heating applications, the choice between recuperated and unrecuperated can be difficult. Ultimately, it depends on the facility's power needs.

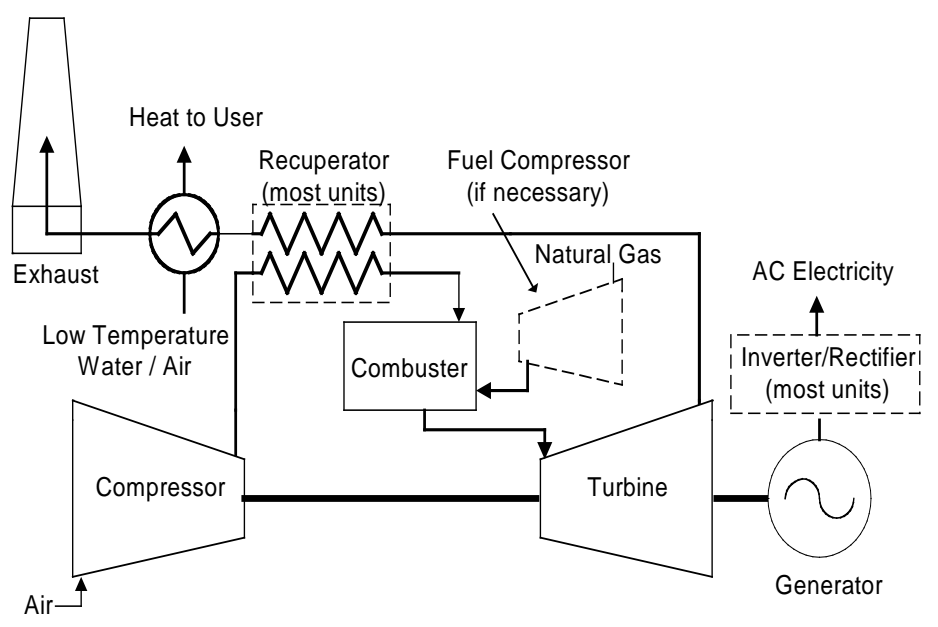

Figure 18. . Microturbine System with Recuperator 


\subsubsection{Emission Controls}

In general, microturbine emissions are slightly lower than industrial turbines and reciprocating engines. $\mathrm{NO}_{\mathrm{x}}$ levels are reported as less than $9 \mathrm{ppm}$ for the Capstone microturbine (30 kW) running on natural gas, without the use of any emission control technologies. Achieving less than $9 \mathrm{ppm}$ is also the goal for microturbine projects using LFG and ADG, but this can be difficult to obtain if the methane percentage falls below 40 percent. Still, $\mathrm{NO}_{\mathrm{x}}$ emissions of less than $9 \mathrm{ppm}$ can almost always be achieved as long as a $15 \%$ excess oxygen mix is used. Some field tests show that when operating at part-load, $\mathrm{NO}_{\mathrm{x}}$ emissions for microturbines are significantly higher than $9 \mathrm{ppm}$, but the units' small size usually exempts them from emissions regulations.

Emission control technologies in microturbines would tend to focus on combustor design and flame control. However, because of their small size, these units can fall below most compliance requirement triggers. As a result, most microturbine installations have been exempt from emission regulations, and they are a common choice for small financially-assisted ADG and LFG projects at farms, wastewater treatment plants and landfills.

\subsubsection{Efficiency}

Recuperators (air-to-air heat exchangers that use exhaust gases to preheat the combustor inlet air) can improve microturbine electric efficiency to between $20-30 \%$ versus the $14-20 \%$ efficiency rates of nonrecuperated units. Microturbines running on low-Btu gases are somewhat less efficient due to the lower heat content. Obtaining a higher efficiency may require higher engine temperatures necessitating improvements in recuperator materials (such as ceramics). Microturbine efficiency is impacted by the available fuel's pressure level. Units that are supplied high-pressure gas (50-60 psig) are 1-4\% more efficient than those using low-pressure gas because of the parasitic requirements of the fuel compressor. Recently, electric efficiencies of 25-29 percent and CHP efficiencies of about 65 percent have become common for ADG/LFG microturbine installations.

\subsubsection{Equipment Costs and Modifications for Opportunity Fuels}

Microturbine cost estimates have lowered considerably since the 2006 report, but experience with microturbine installations has shown that ADG and LFG need to be treated thoroughly for siloxanes and hydrogen sulfide prior to utilization. The gas also needs to be highly compressed prior to utilization. This pretreatment and compression equipment is expensive, especially for small microturbines on a per $\mathrm{kW}$ basis.

Although microturbines are more expensive than traditional prime mover technologies, they can be deployed in smaller applications and they tend to produce fewer harmful emissions. The cost to install a microturbine system generally ranges from $\$ 2,000$ to $\$ 3,000$ per $\mathrm{kW}$. Additional pretreatment equipment is required for medium-Btu gases like ADG and LFG, adding another $\$ 1,000-\$ 3,000$ per $\mathrm{kW}$, installed. For small $30 \mathrm{~kW}$ systems, the pretreatment costs are extremely high on a unit-basis (around \$3,000/kW). The same type of pretreatment equipment is needed to remove hydrogen sulfide and siloxanes, regardless of project size, so smaller systems are hit particularly hard. The total costs for medium-Btu microturbine installations range from $\$ 3,000-\$ 5,000$ per $\mathrm{kW}$, depending largely on unit size and pretreatment 
requirements. The average cost of ADG microturbine installations has been estimated at $\$ 4,000 / \mathrm{kW} .{ }^{106}$ CHP equipment is typically included in the microturbine package, and most vendors now include fuel pretreatment equipment as part of a total package for medium-Btu biogas fuels. ${ }^{107}$

Microturbines were designed to work well with a variety of gases, and can handle methane contents as low as 35 percent, making them ideal for medium-Btu gases like LFG and ADG. However, microturbines do have problems handling fuels that contain hydrogen sulfide and siloxanes, so these particulates must be removed from the gas prior to combustion, and the cost for pretreatment is excessively high for small gensets. Also, with medium-Btu biogases and coalbed methane, additional fuel compression is required to compress the gas to 55 psig. The capital cost of the fuel compressor can range from $\$ 100-\$ 300 / \mathrm{kW}$, with an additional maintenance cost of up to $\$ 0.005 / \mathrm{kWh}$. It also requires a significant amount of power to operate - roughly 10 percent of the microturbine's power output. For example, a microturbine rated at $30 \mathrm{~kW}$ is only capable of producing $27 \mathrm{~kW}$ of usable power when a fuel compressor is required. ${ }^{108}$ This can indirectly affect the cost per $\mathrm{kW}$ of microturbine systems.

\subsubsection{Maintenance Costs and Issues with Opportunity Fuels}

Microturbines are different from conventional turbines in that they contain only one rotating part, and do not require liquids for cooling or lubrication. For a microturbine running on natural gas, overall maintenance typically costs between $\$ 0.012$ and $\$ 0.025$ per $\mathrm{kWh} .{ }^{109}$ Microturbines are designed so that they can run on nearly any methane-based gas, including the medium-Btu waste gases, with minimal effects on performance. More maintenance is required, however, especially for the fuel compressor, and pretreatment equipment which can effectively double the maintenance costs, resulting in high operational costs for smaller units. Average maintenance costs for landfill gas microturbines with full pretreatment can reach 4-5 cents per kWh according to the EPA. ${ }^{110}$ Overall, operation and maintenance costs for medium-Btu fuels are expected to range from $\$ 0.025$ to $\$ 0.04$ per $\mathrm{kWh}$ for most units. With ADG, maintenance costs for the digester are expected to fall between $\$ 0.002$ and $\$ 0.005$ per $\mathrm{kWh}$ for these relatively small installations. With coalbed methane, natural gas maintenance costs should apply, with an additional $\$ 0.002$ per $\mathrm{kWh}$ of maintenance will likely be required for fuel compression and pretreatment equipment.

Table 8 provides the price and performance parameters for CHP microturbine systems running on opportunity fuels.

\footnotetext{
${ }^{106}$ Opportunities for and Benefits of Combined Heat and Power at Wastewater Treatment Facilities: Market Analysis and Lessons from the Field, United States Environmental Protection Agency, Combined Heat and Power Partnership, October 2011.

${ }^{107}$ As of 2007, Capstone and Ingersoll Rand offered pretreatment packages for their 65-kW and 70-kW units, with vendors' quoted installed costs totaling between $\$ 3,000$ and $\$ 4,000 / \mathrm{kW}$ when two or three units are purchased together.

${ }^{108}$ At temperatures above $65^{\circ} \mathrm{F}$, the Capstone C30's maximum power output drops below $30 \mathrm{~kW}\left(25 \mathrm{~kW}\right.$ at $\left.90^{\circ} \mathrm{F}\right)$, and using a medium-Btu fuel will further bring it down.

${ }^{109}$ Catalog of CHP Technologies: Technology Characterization: Microturbines, U.S. Environmental Protection Agency Combined Heat and Power Partnership, prepared by Energy and Environmental Analysis, December 2008.

${ }^{110}$ Project Development Handbook, United States Environmental Protection Agency, Landfill Methane Outreach Program, April 2011, http://www.epa.gov/lmop/publications-tools/handbook.html
} 
Table 8. Price and Performance Parameters for CHP Microturbines (Full Pretreatment)

\begin{tabular}{|l|c|c|c|c|}
\hline Opportunity Fuel & $\begin{array}{c}\text { Installed Cost } \\
\mathbf{( \$ / k W )}\end{array}$ & $\begin{array}{c}\text { Maintenance } \\
\text { Cost } \mathbf{( \$ / k W h )}\end{array}$ & $\begin{array}{c}\text { Electric } \\
\text { Efficiency } \\
\mathbf{( H H V )}\end{array}$ & $\begin{array}{c}\text { CHP } \\
\text { Efficiency } \\
\mathbf{( H H V )}\end{array}$ \\
\hline Anaerobic Digester Gas & $\$ 3,000-\$ 5,000$ & $\$ 0.025-\$ 0.04$ & $25-29 \%$ & $65-67 \%$ \\
\hline Landfill Gas & $\$ 3,000-\$ 5,000$ & $\$ 0.025-\$ 0.04$ & $25-29 \%$ & $65-67 \%$ \\
\hline Coalbed Methane & $\$ 2,200-\$ 3,500$ & $\$ 0.014-\$ 0.027$ & $26-30 \%$ & $65-68 \%$ \\
\hline
\end{tabular}

\subsubsection{Applications for Microturbines}

Perhaps the greatest advantage of microturbines is their ability to accept a wide range of fuel types with no modifications. However, harmful impurities must be properly removed with effective pretreatment, and this can be cost-prohibitive for smaller units that require full treatment.

Microturbines have a very small footprint, which makes them ideal for distributed energy applications, and their design allows for easy CHP implementation. Microturbines produce low emissions, so they have gained traction in New York and other areas with strict environmental regulations. Microturbines could become an increasingly common technology for small CHP applications, especially with gaseous opportunity fuels, but capital and maintenance costs are currently too high to compete with small engines purely on economics in most applications.

\subsection{FUEL CELLS}

Fuel cells are an emerging small-scale power generation technology, mostly under $1 \mathrm{MW}$, although larger applications with solid oxide fuel cells have been implemented. The first fuel cell was developed in 1839 by Sir William Grove. However, they were not used as practical generators of electricity until the 1960's when they were installed in NASA's Gemini and Apollo spacecraft. One company, UTC Fuel Cells, currently manufactures a the PureCell 400, a $400 \mathrm{~kW}$ phosphoric acid fuel cell that can be used in commercial and industrial applications. These fuel cells have been successfully incorporated into ADG power applications, but financial assistance has always been required for successful project economics. FuelCell Energy is the other major commercial manufacturer, producing molten carbonite fuel cells with $300 \mathrm{~kW}, 1.4 \mathrm{MW}$ and 2.8 MW configurations. Bloom Energy is an emerging fuel cell manufacturer producing solid oxide fuel cells for small commercial applications, but these do not produce thermal output. 


\subsubsection{Operation}

There are many types of fuel cells, but each uses the same basic principle to generate power. A fuel cell consists of two electrodes (an anode and a cathode) separated by an electrolyte. Hydrogen fuel is fed into the anode, while oxygen (or air) enters the fuel cell through the cathode. With the aid of a catalyst, the hydrogen atom splits into a proton $(\mathrm{H}+)$ and an electron. The proton passes through the electrolyte to the cathode, and the electrons travel through an external circuit connected as a load, creating a DC current. The electrons continue on to the cathode, where they combine with hydrogen and oxygen, producing water and heat. A typical fuel cell is illustrated in Figure 19.

The main differences between fuel cell types are in their electrolytic material. Each different electrolyte has both benefits and disadvantages, based on materials and manufacturing costs, operating temperature, achievable efficiency, power to volume (or weight) ratio, and other operational considerations. Phosphoric acid and molten carbonate fuel cells were the first to be commercially developed for power generation, although solid oxide and proton exchange membrane fuel cells have seen more recent research and development, with units like the Bloom Energy fuel cell (solid oxide) being sold for commercial applications in Southern California. These units have very high electric efficiencies, at up to 55 percent. Proton exchange membrane (PEM) fuel cells have been developed for various small DG/CHP applications, but commercialized power generating units are not currently being produced.

Fuel cells require hydrogen for operation. However, it is generally impractical to use hydrogen directly as a fuel source; instead, it is extracted from hydrocarbon fuels using a reformer. Cost effective, efficient fuel reformers that can convert various fuels to hydrogen are necessary to allow fuel cells increased flexibility and commercial feasibility. Fuel reformers have been built to extract hydrogen from almost any type of fuel, including anaerobic digester gas and landfill gas. The part of a fuel cell that contains the electrodes and electrolytic material is called the "stack," and is a major component of the cost of the total system. Stack replacement is very costly but becomes necessary when efficiency degrades as operating hours accumulate.

United Technology Corporation's phosphoric acid fuel cells can easily be used in two different types of industrial cogeneration applications: to produce hot water at around $140^{\circ} \mathrm{F}$, or to produce hot water at around $140^{\circ} \mathrm{F}$ and low temperature steam at $250^{\circ} \mathrm{F}$. Overall CHP efficiency for both is around $80 \%$.

Proton exchange membrane (PEM) and alkaline fuel cells operate at lower temperatures, so only hot water and space heating applications are possible. PEM fuel cells are most commonly used in very smallscale electricity generation applications, with limited heat recovery. Solid oxide and molten carbonate fuel cells, however, operate at extremely high temperatures (over $1000^{\circ} \mathrm{F}$ ) so they can be used in a number of cogeneration applications, as well as fuel cell-turbine hybrid systems. 


\subsubsection{Emission Controls}

Fuel cells have very low levels of $\mathrm{NO}_{\mathrm{x}}$ and $\mathrm{CO}$ emissions because the power conversion process is electrochemical rather than combustion-based. For this reason, as emission standards become increasingly stringent, fuel cells will offer a clear advantage, especially in non-attainment zones. To date, fuel cells have been exempt from environmental regulations in most parts of the United States.

\subsubsection{Efficiency}

Fuel cells are the most consistently efficient power generating technology. Fuel cells generate electricity at efficiencies ranging from 35 to 55 percent, with an overall efficiency of up to $80 \%$ if the by-product thermal energy produced by the fuel cell is used for cogeneration.

\subsubsection{Equipment Costs and Modifications for Opportunity Fuels}

Fuel cells are currently very expensive to purchase, but they are expected to decline in price over time, and they may become more competitive with the other power generating technologies. The costs for fuel cells have not changed considerably since the 2006 report. The cost to install a natural gas fuel cell system has previously been estimated at $\$ 4,000-\$ 6,000$ per $\mathrm{kW}$, with some units costing even more. ${ }^{111}$ Some of the latest commercially available fuel cells, UTC's PureCell 400 and FuelCell Energy's DFC series, however, have been estimated to cost a more economical $\$ 3,000-\$ 5,000$ per $\mathrm{kW}$ in more recent analyses. $^{112}$

Fuel cells normally run on natural gas, using a fuel reformer to extract hydrogen from methane. Fuel cells can also be configured to run on anaerobic digester gas or landfill gas, but they require a slightly different fuel reformer, with a larger fuel injector and larger piping. For ADG and LFG, extensive scrubbing is sometimes necessary to neutralize the sulfur and halides, along with pretreatment equipment for removing hydrogen sulfide and/or siloxanes. Most fuel cells running on ADG or LFG can expect to add \$500$\$ 1,000 / \mathrm{kW}$ to the installed costs to cover these additional requirements. Coalbed methane, with similar properties to natural gas, could be used to power fuel cells with minimal modifications or additional treatment equipment.

\subsubsection{Maintenance Costs and Issues with Opportunity Fuels}

Current fuel cells typically cost between $\$ 0.03$ and $\$ 0.04$ per kWh to maintain. ${ }^{113}$ Because no combustion occurs in a fuel cell system, there is not as much deposit buildup, although fuel purity is

\footnotetext{
${ }^{111}$ Catalog of CHP Technologies: Technology Characterization: Fuel Cells, U.S. Environmental Protection Agency Combined Heat and Power Partnership, prepared by Energy and Environmental Analysis, December 2008.

${ }^{112}$ Analysis of Hydrogen Energy Stations for Initial Hydrogen Infrastructure Along I-95 Corridor, Prepared for U.S. Department of Energy, Prepared by: Resource Dynamics Corporation and Concurrent Technologies Corporation, May 2009.

${ }^{113}$ Ibid.
} 
important to avoid sulfur contamination. Since they are a relatively new technology, trained professionals must be contracted to maintain the unit, which increases maintenance costs. Most of the O\&M issues with fuel cells stem from the fuel reformer, which converts hydrocarbon fuels into pure hydrogen. Using a lower Btu fuel with more impurities will require increased cleaning and maintenance of the fuel reformer. Overall, ADG and LFG powered fuel cells should cost between \$0.04 and \$0.06 per kWh to maintain. Fuel cells running on coalbed methane should have roughly the same maintenance cost as natural gas, although the fuel reformer may require more frequent cleaning. Stack replacement, which can add significant costs later in the fuel cell's life, also needs to be taken into consideration.

Table 9 provides the price and performance parameters for CHP fuel cell installations, including installed cost, maintenance costs, and efficiencies.

Table 9. Price and Performance Parameters for CHP Fuel Cells (Full Pretreatment)

\begin{tabular}{|c|c|c|c|c|}
\hline Opportunity Fuel & $\begin{array}{c}\text { Installed Cost } \\
(\$ / \mathbf{k W})\end{array}$ & $\begin{array}{l}\text { Maintenance } \\
\text { Cost (\$/kWh) }\end{array}$ & $\begin{array}{c}\text { Electric } \\
\text { Efficiency } \\
\text { (HHV) }\end{array}$ & $\begin{array}{c}\text { CHP } \\
\text { Efficiency } \\
\text { (HHV) }\end{array}$ \\
\hline Anaerobic Digester Gas & $\$ 3,500-\$ 6,000$ & $\$ 0.04-\$ 0.06$ & $35-55 \%$ & $70-80 \%$ \\
\hline Landfill Gas & $\$ 3,500-\$ 6,000$ & $\$ 0.04-\$ 0.06$ & $35-55 \%$ & $70-80 \%$ \\
\hline Coalbed Methane & $\$ 3,000-\$ 5,000$ & $\$ 0.035-\$ 0.05$ & $35-55 \%$ & $70-80 \%$ \\
\hline
\end{tabular}

\subsubsection{Applications for Fuel Cells}

Since fuel cells are a relatively new and developing CHP technology, their availability is limited, and they have only been successful in projects with significant government funding and assistance. Phosphoric acid fuel cells have been used in anaerobic digester gas projects at wastewater treatment centers, and the results have been mixed, with many projects opting not to continue using the technology. While it is possible that fuel cells will provide a viable CHP alternative in the future, their high costs are prohibitive for most current projects.

\subsection{CHAPTER 3 SUMMARY}

The equipment and maintenance costs for opportunity-fueled CHP are summarized in Table 10. The Federal Investment Tax Credit, which effectively reduces the cost of the units by 10 percent, is not included in these figures, but it would be applicable to all of the CHP units with the possible exception of some of steam turbine configurations.

The cost data was obtained by taking the low and high cost estimates developed for CHP systems (estimated using DOE technology characterizations, vendor quotes, and various data sources), and adding any estimated costs that would be incurred for systems using opportunity fuels (from case studies and conversations with equipment manufacturers). While the price ranges are often large, they give an idea to how much an average opportunity fuels project would cost in comparison with the different prime mover technologies. For anaerobic digester gas, it is assumed that the facility must purchase an anaerobic 
digester, so this is included in the costs. All of these systems are assumed to be installed for CHP applications, so thermal recovery equipment is included.

In the following chapters, the availability and potential capacity for each of the six most promising opportunity fuels are examined, and the current status and future outlook is discussed for each fuel. 
Table 10. Equipment and Maintenance Average Costs for CHP Equipment (Full Pretreatment)

\begin{tabular}{|c|c|c|c|c|c|c|}
\hline & & $\begin{array}{l}\text { Steam Turbines }{ }^{\star *} \\
(1-50 \mathrm{MW})\end{array}$ & $\begin{array}{c}\text { Combustion Turbines } \\
(1-50 \mathrm{MW})\end{array}$ & $\begin{array}{c}\text { Reciprocating Engines } \\
(30 \mathrm{~kW}-10 \mathrm{MW})\end{array}$ & $\begin{array}{l}\text { Microturbines } \\
(30 \mathrm{~kW}-1 \mathrm{MW})\end{array}$ & $\begin{array}{c}\text { Fuel Cells } \\
(10 \mathrm{~kW}-2 \mathrm{MW})\end{array}$ \\
\hline \multirow{2}{*}{ Anaerobic Digester Gas* } & Equipment $(\$ / \mathrm{kW})$ & \multirow{2}{*}{$\mathrm{N} / \mathrm{A}$} & $\$ 1,500-\$ 4,000$ & $\$ 1,800-\$ 5,000$ & $\$ 3,000-\$ 5,000$ & $\$ 4,000-\$ 6,000$ \\
\hline & Maintenance (\$/kWh) & & $\$ 0.010-\$ 0.025$ & $0.020-0.040$ & $\$ 0.025-\$ 0.040$ & $\$ 0.040-\$ 0.060$ \\
\hline \multirow{2}{*}{ Coalbed Methane } & Equipment $(\$ / \mathrm{kW})$ & \multirow{2}{*}{$\mathrm{N} / \mathrm{A}$} & $\$ 1,000-\$ 3,000$ & $\$ 1,100-\$ 2,500$ & $\$ 2,200-\$ 3,500$ & $\$ 3,000-\$ 5,000$ \\
\hline & Maintenance (\$/kWh) & & $\$ 0.006-\$ 0.014$ & $\$ 0.010-\$ 0.022$ & $\$ 0.014-\$ 0.027$ & $\$ 0.035-\$ 0.050$ \\
\hline \multirow{2}{*}{ Landfill Gas } & Equipment $(\$ / \mathrm{kW})$ & \multirow{2}{*}{$\mathrm{N} / \mathrm{A}$} & $\$ 1,500-\$ 4,000$ & $\$ 1,800-\$ 5,000$ & $\$ 3,000-\$ 5,000$ & $\$ 4,000-\$ 6,000$ \\
\hline & Maintenance $(\$ / \mathrm{kWh})$ & & $\$ 0.010-\$ 0.025$ & $0.020-0.040$ & $\$ 0.025-\$ 0.040$ & $\$ 0.040-\$ 0.060$ \\
\hline \multirow{2}{*}{ Forest Residues } & Equipment $(\$ / \mathrm{kW})$ & $\$ 2,500-\$ 11,000$ & \multirow{2}{*}{$\mathrm{N} / \mathrm{A}$} & \multirow{2}{*}{$\mathrm{N} / \mathrm{A}$} & \multirow{2}{*}{$\mathrm{N} / \mathrm{A}$} & \multirow{2}{*}{$\mathrm{N} / \mathrm{A}$} \\
\hline & Maintenance (\$/kWh) & $\$ 0.015-\$ 0.15$ & & & & \\
\hline \multirow{2}{*}{ Tire-Derived Fuel } & Equipment $(\$ / \mathrm{kW})$ & $\$ 2,000-\$ 9,000$ & \multirow{2}{*}{$\mathrm{N} / \mathrm{A}$} & \multirow{2}{*}{$\mathrm{N} / \mathrm{A}$} & \multirow{2}{*}{$\mathrm{N} / \mathrm{A}$} & \multirow{2}{*}{$\mathrm{N} / \mathrm{A}$} \\
\hline & Maintenance $(\$ / \mathrm{kWh})$ & $\$ 0.01-\$ 0.12$ & & & & \\
\hline \multirow{2}{*}{ Wood Waste } & Equipment $(\$ / \mathrm{kW})$ & $\$ 2,500-\$ 11,000$ & \multirow{2}{*}{$\mathrm{N} / \mathrm{A}$} & \multirow{2}{*}{$\mathrm{N} / \mathrm{A}$} & \multirow{2}{*}{$\mathrm{N} / \mathrm{A}$} & \multirow{2}{*}{$\mathrm{N} / \mathrm{A}$} \\
\hline & Maintenance (\$/kWh) & $\$ 0.015-\$ 0.15$ & & & & \\
\hline
\end{tabular}

*Not including digester costs

**Including boiler costs - per-kW costs vary greatly depending on level of electricity generation (condensing/extraction/back-pressure turbine) 



\section{AVAILABILITY AND TECHNICAL POTENTIAL}

This chapter investigates the availability of resources for each opportunity fuel, and estimates their maximum potential thermal and electric capacity in the United States. Availability is examined on a stateby-state basis with updated data to predict the best potential areas of supply for each fuel, and this data is then used to estimate the technical potential.

The availability of opportunity fuels depends on a number of factors, including local resources, processing plants, and market infrastructures. For anaerobic digester gas and landfill gas, facilities are located ubiquitously throughout the country. The availability of coalbed methane, on the other hand, is highly regional, depending on the prevalence of underground coal reserves and the locations of mines. Tire piles for tire-derived fuel are located throughout the country, generally more prevalent around highpopulation areas. Harvested wood fuels are most readily available in heavily forested areas which tend to be more rural, while the availability of urban wood waste is more population-based.

For each fuel type, the availability data is explained and presented in tabular and graphic form, when applicable. After the data is discussed, rough estimates for the potential thermal and electric capacity of each fuel are made - the technical potential of each fuel, which does not include any economic considerations. For the purposes of this project, only the continental United States is evaluated.

\subsection{ANAEROBIC DIGESTER GAS}

The two largest markets for anaerobic digester gas are wastewater treatment plants (WWTPs) and animal farms. While animal farms are usually not ideal for CHP applications because of their rural location and limited electric demand, they have been successful in collaborations with third parties and utilities that can utilize the energy produced. Food processing waste and other organic waste streams can also produce ADG, and these sources are included with the analysis of industrial WWTPs. But the largest potential source of new ADG CHP projects is likely to be municipal wastewater treatment plants.

\subsubsection{Availability: Wastewater Treatment Plants}

Wastewater treatment plants are located ubiquitously throughout the United States. There are approximately 60,000 industrial and 16,000 municipal WWTPs in the country, ${ }^{114}$ although most industrial plants do not produce the appropriate organic waste stream for anaerobic digestion, and the vast majority of treatment plants are not large enough to support ADG energy projects. With municipal plants, primarily used for treating sewage water, location and size are directly related to population. Industrial WWTPs however, are more regional, depending on the type of plant and the location of resources. Food and beverage processing are by far the most common industries for anaerobic wastewater treatment, followed by pulp, paper, and petrochemicals. ${ }^{115}$

\footnotetext{
${ }^{114}$ MagnaDrive News Releases - New Technology from MagnaDrive Corp. Offers Dramatic Energy Savings to Water/Wastewater Treatment Industry. May 2003. http://www.magnadrive.com/news/news-121200.shtml

${ }^{115}$ Kleerebezem, Robbert and Herve Macarie. “Process Wastewaters: Anaerobic’s Bigger Bite”. Chemical Engineering. April 2003.
} 
While not all wastewater treatment plants are suited for ADG projects (many simply do not process enough waste), most plants that are capable of utilizing ADG require a Water Discharge Permit, issued by the Environmental Protection Agency. The EPA Envirofacts Warehouse website contains a database of Water Discharge Permits issued to various facilities throughout the United States. Facility information, including the wastewater flow rate, is included in the data when available. To determine the availability and technical potential of ADG, a correlation must be made between the wastewater flow rate and the amount of gas produced. From that, and the potential amount of electricity generation can be determined.

A Focus on Energy study assessing digester gas to energy projects in Wisconsin profiled 60 different municipal wastewater treatment plants, giving the daily wastewater flow rate and digester gas production for each facility. ${ }^{116}$ The results were averaged for facilities producing more than 1 million gallons per day (MGD) of wastewater, and it was found that a facility that producing 1 MGD generates about 8.4 cubic feet of biogas each minute. At $600 \mathrm{Btu} / \mathrm{ft} 3$ and with an electric efficiency of 30\%, a total of about $27 \mathrm{~kW}$ could be produced from this gas, enough to support a $30 \mathrm{~kW}$ microturbine installation. Biogas production volumes can vary seasonally, which can impact system sizing, but this analysis assumes that those producing 1 MGD on average would have enough fuel for a $30 \mathrm{~kW}$ CHP system. Facilities producing less than 1 MGD are not good candidates for CHP, so this is where the cutoff was made. In general, sites processing more than 7 MGD (capable of producing $200 \mathrm{~kW}$ or more) are the best candidates for CHP projects

The latest EPA Clean Watersheds Needs Survey ${ }^{117}$ database was queried for municipal wastewater treatment plants producing at least 1 MGD of wastewater. About 100 municipal facilities with known ADG CHP installations were removed from consideration. ${ }^{118}$ In addition to this data, water discharge permits from the EPA's Envirofacts ${ }^{119}$ database, which also covers industrial treatment plants, were queried for industrial facilities processing at least 1 MGD of wastewater. The resulting data for each state is summarized in Table 11 and Figure 20.

\footnotetext{
${ }^{116}$ Vik, Thomas E. Anaerobic Digester Methane to Energy - A Wisconsin Statewide Assessment. Prepared for Focus On Energy by McMahon Associates, Inc. January 23, 2003.

${ }^{117}$ U.S. Environmental Protection Agency, 2008 Clean Watersheds Needs Survey, http://water.epa.gov/scitech/datait/databases/cwns/2008reportdata.cfm.

${ }^{118}$ Combined Heat and Power at Wastewater Treatment Facilities: Opportunities and Operational Experience, U.S. Environmental Protection Agency, Combined Heat and Power Partnership, August 2011.

${ }^{119}$ U.S. Environmental Protection Agency, Envirofacts Database, 2011, http://www.epa.gov/enviro/.
} 
Table 11. Wastewater Treatment Plants: Potential Projects and Capacity by State

\begin{tabular}{|c|c|c|c|}
\hline State & Potential Projects & Wastewater Flow (MGD) & Technical Potential, MW \\
\hline Alaska & 10 & 63 & 2 \\
\hline Alabama & 90 & 402 & 11 \\
\hline Arkansas & 54 & 215 & 6 \\
\hline Arizona & 51 & 414 & 11 \\
\hline California & 219 & 2,556 & 69 \\
\hline Colorado & 41 & 181 & 5 \\
\hline Connecticut & 52 & 367 & 10 \\
\hline Delaware & 9 & 97 & 3 \\
\hline Florida & 192 & 1,308 & 35 \\
\hline Georgia & 84 & 690 & 19 \\
\hline Hawaii & 11 & 135 & 4 \\
\hline lowa & 66 & 231 & 6 \\
\hline Idaho & 27 & 92 & 2 \\
\hline Illinois & 147 & 2,071 & 56 \\
\hline Indiana & 106 & 738 & 20 \\
\hline Kansas & 49 & 256 & 7 \\
\hline Kentucky & 59 & 352 & 9 \\
\hline Louisiana & 72 & 476 & 13 \\
\hline Massachusetts & 64 & 431 & 12 \\
\hline Maryland & 36 & 263 & 7 \\
\hline Maine & 32 & 116 & 3 \\
\hline Michigan & 77 & 1,280 & 35 \\
\hline Minnesota & 45 & 390 & 11 \\
\hline Missouri & 80 & 705 & 19 \\
\hline Mississippi & 49 & 208 & 6 \\
\hline Montana & 13 & 29 & 1 \\
\hline North Carolina & 106 & 608 & 16 \\
\hline North Dakota & 10 & 42 & 1 \\
\hline Nebraska & 15 & 45 & 1 \\
\hline New Hampshire & 20 & 89 & 2 \\
\hline New Jersey & 86 & 854 & 23 \\
\hline New Mexico & 28 & 115 & 3 \\
\hline Nevada & 18 & 257 & 7 \\
\hline New York & 145 & 2,269 & 61 \\
\hline Ohio & 184 & 1,716 & 46 \\
\hline Oklahoma & 52 & 295 & 8 \\
\hline Oregon & 41 & 170 & 5 \\
\hline Pennsylvania & 187 & 1,005 & 27 \\
\hline Rhode Island & 13 & 127 & 3 \\
\hline South Carolina & 82 & 448 & 12 \\
\hline South Dakota & 11 & 39 & 1 \\
\hline Tennessee & 76 & 661 & 18 \\
\hline Texas & 272 & 1,843 & 50 \\
\hline Utah & 28 & 239 & 6 \\
\hline Virginia & 65 & 670 & 18 \\
\hline Vermont & 13 & 31 & 1 \\
\hline Washington & 75 & 446 & 12 \\
\hline Wisconsin & 75 & 335 & 9 \\
\hline West Virginia & 46 & 150 & 4 \\
\hline Wyoming & 11 & 31 & 1 \\
\hline Total U.S. & 3,394 & 26,547 & 717 \\
\hline
\end{tabular}

Source: EPA: Envirofacts Water Discharge Permits Database and 2008 Clean Water Needs Survey 
Overall, there are close to 3,400 potential ADG projects for wastewater treatment plants. Based on the assumption that plants can produce $27 \mathrm{~kW}$ for every 1 million gallons of water per day that is processed, there is $717 \mathrm{MW}$ of technical potential from wastewater treatment plants, both municipal and industrial.

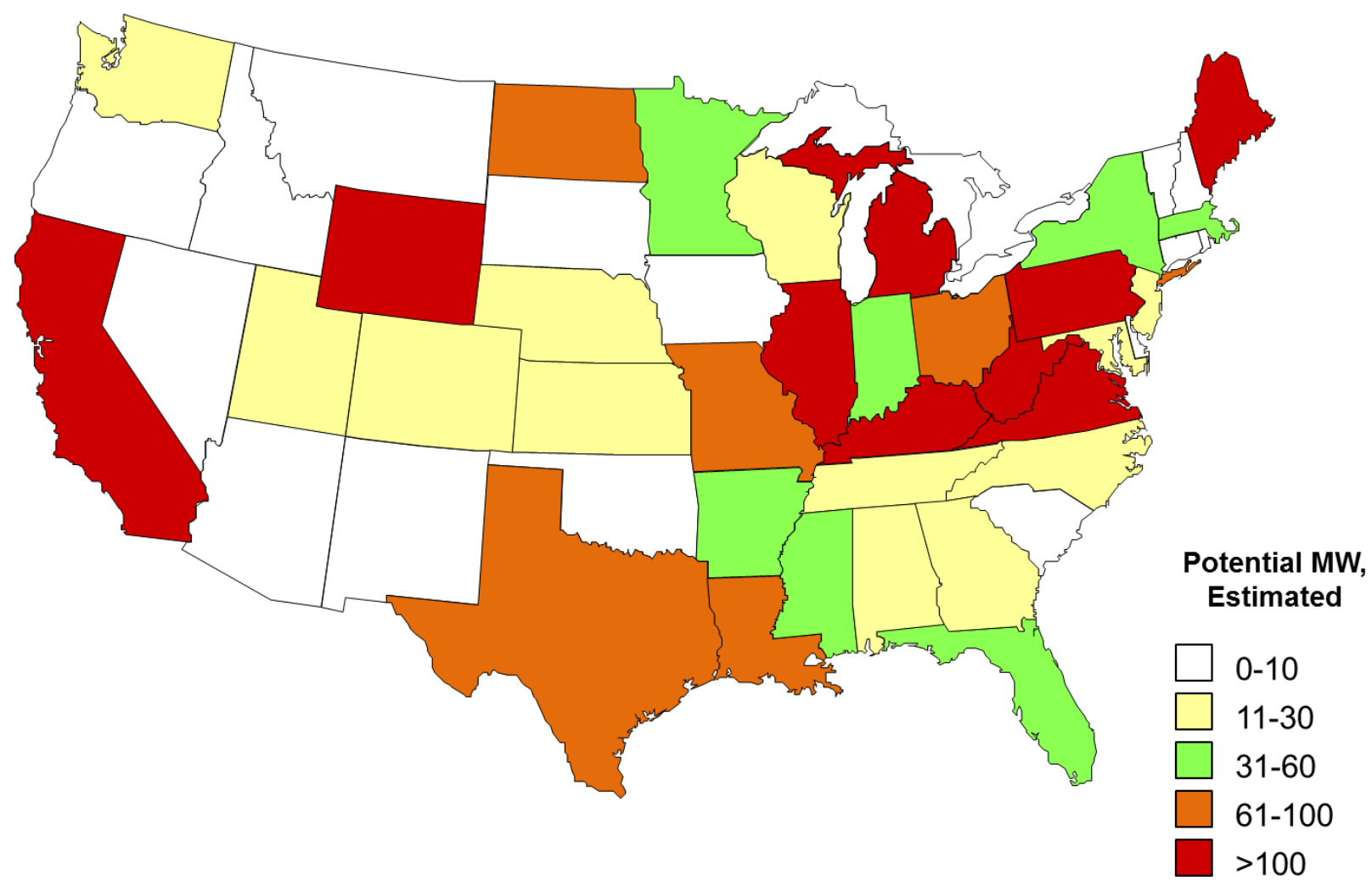

Figure 20. Potential Capacity for WWTP ADG Projects by State

\subsubsection{Availability: Animal Farms}

Most animal farms are not suitable for CHP due to their small size, but there are over 100,000 animal farms in the United States and many of them are capable of benefiting from ADG power. Many farms produce an excess of cow or hog manure, and have trouble finding uses for (or disposing of) this waste. These farms could install anaerobic digesters and utilize the ADG for CHP, potentially selling excess electricity to utilities in a net metering arrangement. Poultry waste can also be used to produce ADG, but it is produced in smaller quantities, its moisture content is lower than hog and cow waste, and its volatile contents evaporate rapidly. Only swine and cow farms are considered in this analysis. According to various sources, a single cow produces enough waste to generate 0.1 to $0.2 \mathrm{~kW}$ of power from ADG, but this number can vary depending on the type of cow (beef/dairy) and the living conditions (close quarters or free range). Hogs generally produce about one-fifth to one-fourth the amount of waste that a cow produces (0.02 to $0.06 \mathrm{~kW}$ per hog), although this number varies as well. Overall, the smallest farms capable of powering a $30 \mathrm{~kW}$ microturbine would contain about 200 cows or $800-1,000$ hogs.

The Census of Agriculture gives information on the number of farms, and the number of animals contained in each state, broken down by size. Farms with over 200 cows or over 1,000 hogs were counted, and the potential MW production estimated. In some cases census data on the number of 
cows/hogs was withheld to avoid releasing data on individual farms, but the size range was still given. In these cases the lowest number in the range was used, and a plus sign was placed next to the total, showing that there may be more cows/hogs than indicated. Using the $\mathrm{kW}$ per livestock values described above, the technical potential (in terms of MW) was found for each state. As expected, the highest concentration of potential farm manure ADG projects lies in the Midwest, although North Carolina and California have the second and fourth highest potential, respectively. The results are summarized in Figure 21 and Table 12.

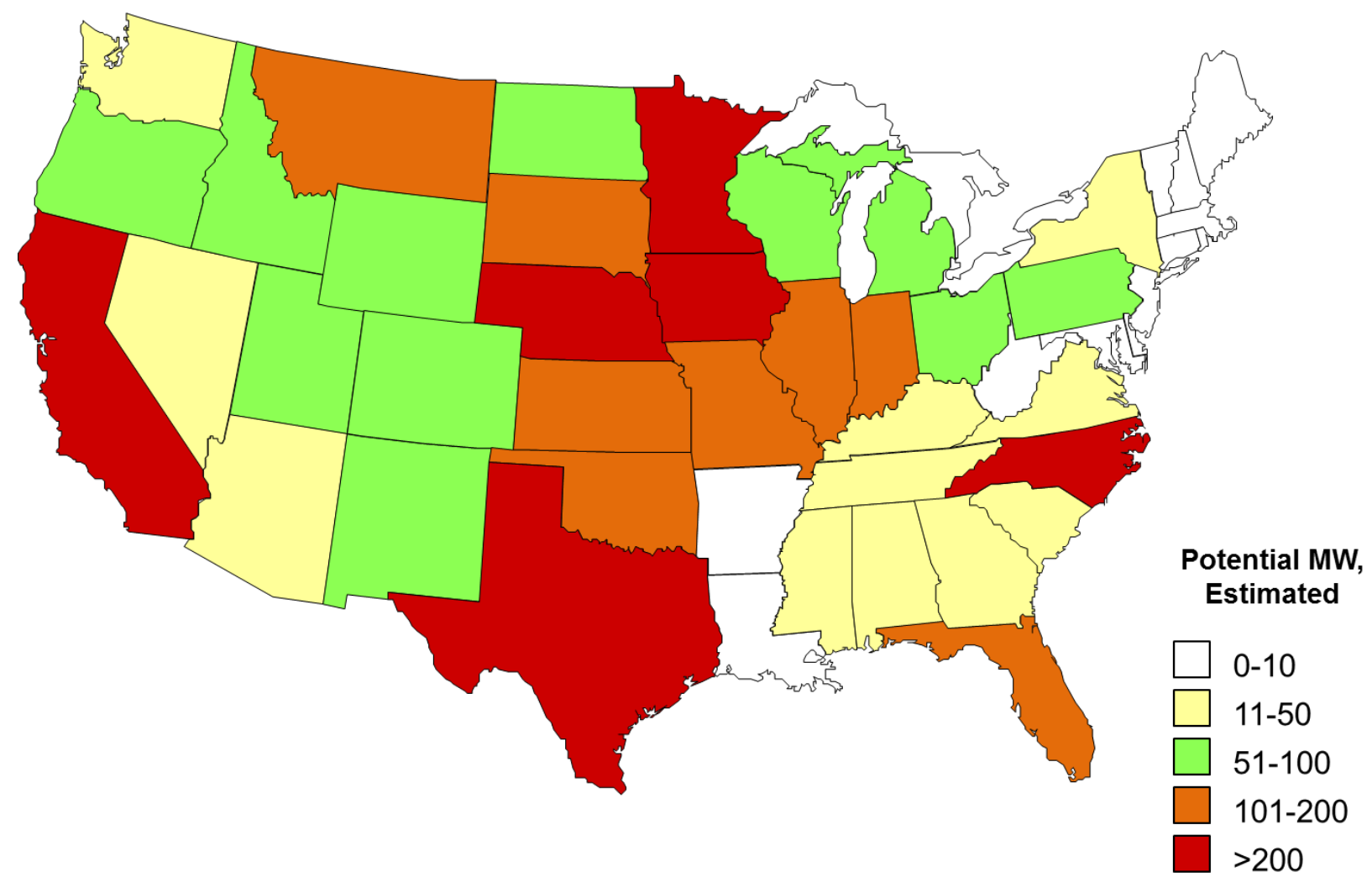

Figure 21. Potential Capacity for Animal Farm ADG Projects by State 
Table 12. Potential MW Production from Cow and Hog Farms Large Enough for CHP Projects

\begin{tabular}{|c|c|c|c|c|c|c|c|}
\hline State & $\begin{array}{c}\text { Farms wl } \\
\text { over } 200 \\
\text { Beef Cows }\end{array}$ & $\begin{array}{c}\text { \# of Beef } \\
\text { Cows }\end{array}$ & $\begin{array}{c}\text { Farms wl } \\
\text { over } 200 \\
\text { Dairy } \\
\text { Cows }\end{array}$ & $\begin{array}{l}\text { \# of Dairy } \\
\text { Cows }\end{array}$ & $\begin{array}{c}\text { Farms wl } \\
\text { over 1,000 } \\
\text { Hogs/Pigs }\end{array}$ & $\begin{array}{c}\text { \# of } \\
\text { Hogs/Pigs }\end{array}$ & $\begin{array}{c}\text { Potential } \\
\text { MW }\end{array}$ \\
\hline Alabama & 453 & 148,322 & 25 & 9,867 & 33 & 145,632 & 30 \\
\hline Arizona & 197 & 109,539 & 92 & 154,027 & 1 & $1,000+$ & 40 \\
\hline Arkansas & 510 & 160,023 & 25 & $6,033+$ & 70 & 247,951 & 35 \\
\hline California & 927 & 444,799 & 1,580 & $1,605,801$ & 10 & 126,594 & 313 \\
\hline Colorado & 883 & 352,201 & 103 & 90,882 & 25 & 720,279 & 95 \\
\hline Connecticut & 0 & 0 & 31 & 11,192 & 0 & 0 & 2 \\
\hline \begin{tabular}{|l} 
Delaware \\
\end{tabular} & 1 & $200+$ & 13 & $3,921+$ & 5 & 7,388 & 1 \\
\hline Florida & 981 & 630,488 & 139 & 133,727 & 2 & $2,000+$ & 115 \\
\hline Georgia & 302 & 93,555 & 102 & 55,867 & 59 & 271,607 & 33 \\
\hline Idaho & 631 & 275,156 & 319 & 359,273 & 3 & 8,591 & 96 \\
\hline Illinois & 126 & 36,989 & 85 & 30,134 & 970 & $3,352,399$ & 144 \\
\hline \begin{tabular}{|l} 
Indiana \\
\end{tabular} & 48 & 12,364 & 80 & 55,505 & 788 & $2,820,959$ & 123 \\
\hline Iowa & 431 & 132,246 & 140 & 64,675 & 3,876 & $13,263,736$ & 560 \\
\hline Kansas & 1,356 & 448,063 & 44 & 76,781 & 197 & $1,374,702$ & 134 \\
\hline Kentucky & 398 & 118,775 & 57 & $14,624+$ & 81 & 304,354 & 32 \\
\hline Louisiana & 386 & 144,406 & 42 & 12,504 & 4 & 5,268 & 24 \\
\hline Maine & 2 & $400+$ & 42 & 14,629 & 0 & 0 & 2 \\
\hline Maryland & 14 & 4,673 & 51 & 20,907 & 11 & $11,000+$ & 4 \\
\hline Massachusetts & 0 & 0 & 18 & $5,199+$ & 2 & $2,000+$ & 1 \\
\hline \begin{tabular}{|l|} 
Michigan \\
\end{tabular} & 15 & $3,986+$ & 295 & 146,521 & 220 & 780,267 & 54 \\
\hline Minnesota & 154 & 45,157 & 287 & 115,108 & 1,624 & $5,534,015$ & 245 \\
\hline Mississippi & 298 & 96,592 & 39 & 12,047 & 39 & 285,858 & 28 \\
\hline Missouri & 1,075 & 347,360 & 55 & 18,986 & 404 & $2,493,691$ & 155 \\
\hline Montana & 2,337 & 987,895 & 21 & $6,319+$ & 40 & 149,671 & 155 \\
\hline Nebraska & 2,303 & 976,640 & 48 & 30,423 & 574 & $2,329,322$ & 244 \\
\hline Nevada & 317 & 213,375 & 23 & 27,945 & 1 & $1,000+$ & 36 \\
\hline New Hampshire & 0 & 0 & 15 & $3,900+$ & 0 & 0 & 1 \\
\hline New Jersey & 3 & 620 & 8 & $2,632+$ & 3 & 5,952 & 1 \\
\hline New Mexico & 690 & 332,581 & 153 & 313504 & 0 & 0 & 97 \\
\hline \begin{tabular}{|l|} 
New York \\
\end{tabular} & 6 & 1,291 & 576 & 274,265 & 17 & 51,194 & 43 \\
\hline North Carolina & 131 & 41,153 & 75 & 27,692 & 1,404 & $9,803,370$ & 402 \\
\hline \begin{tabular}{|l|} 
North Dakota \\
\end{tabular} & 1,257 & 379,631 & 19 & 7,589 & 22 & 92,530 & 62 \\
\hline Ohio & 47 & 14,156 & 165 & 65,377 & 413 & $1,024,696$ & 53 \\
\hline Oklahoma & 1,459 & 503,136 & 48 & 35,937 & 102 & $2,183,182$ & 168 \\
\hline Oregon & 713 & 355,559 & 136 & 87,829 & 2 & $2,000+$ & 67 \\
\hline Pennsylvania & 13 & 3,108 & 325 & 111,345 & 315 & 971,354 & 56 \\
\hline Rhode Island & 0 & 0 & 1 & $200+$ & 0 & 0 & 0 \\
\hline South Carolina & 87 & 27,886 & 35 & 11,429 & 55 & 251,158 & 16 \\
\hline South Dakota & 2,503 & 889,935 & 55 & 32,180 & 257 & $1,123,301$ & 183 \\
\hline \begin{tabular}{|l} 
Tennessee \\
\end{tabular} & 329 & 95,316 & 86 & 26,211 & 44 & 160,466 & 25 \\
\hline Texas & 4,716 & $1,926,067$ & 409 & 256,745 & 20 & 856,624 & 362 \\
\hline Utah & 419 & 181,484 & 124 & 63,822 & 14 & 659,169 & 63 \\
\hline Vermont & 2 & $400+$ & 163 & 65,335 & 0 & 0 & 10 \\
\hline Virginia & 314 & 102,236 & 110 & 35,180 & 42 & 387,054 & 36 \\
\hline Washington & 228 & 97,473 & 323 & 208,338 & 8 & 13,564 & 46 \\
\hline West Virginia & 29 & 8,723 & 14 & $4,277+$ & 2 & $2,000+$ & 2 \\
\hline Wisconsin & 45 & 14,239 & 839 & 346,576 & 119 & 278,781 & 65 \\
\hline Wyoming & 1,193 & 546,525 & 5 & $1,000+$ & 3 & 104,635 & 86 \\
\hline U.S. Total & 28,329 & $11,304,723$ & 7,440 & $5,064,260$ & 11,881 & $52,210,314$ & 4,544 \\
\hline
\end{tabular}

Source: 2002 United States Census of Agriculture: http://www.nass.usda.gov/census/census02/volume1/index2.htm 
If all of the manure from all of the cows and hogs on United States farms capable of ADG projects was utilized for CHP, approximately $4.5 \mathrm{GW}$ of electricity could be produced. If nearby facilities could productively use the thermal load in all of these cases, a thermal output of 124 trillion Btu/year could be obtained, assuming typical CHP efficiencies and 6,000 hours of operation. While this technical potential is greater than what was calculated for wastewater treatment plants, the economic potential for CHP at farms is likely to be dramatically lower, due to the lack of nearby electric and thermal demand and the higher capital cost per unit kW for smaller projects.

With both WWTPs and animal farms considered, the total technical potential for ADG is about $5.3 \mathrm{GW}$ of electricity and 150 million MMBtu/year of thermal output. This could potentially be increased by the addition of fats oils and greases, and other food processing wastes, to anaerobic digester operations.

\subsection{COALBED METHANE}

The location of coal reserves in the United States is highly regional, so the market for coalbed methane (CBM) is regional as well. Many of the nation's coal reserves remain untapped and could be drilled for methane gas, but coalbed methane for CHP is only considered at operational underground coalmines that can utilize their gas as an energy source. Surface mines produce some methane, but much higher quantities are available at underground mines, as methane concentrations typically increase with depth. The states with the greatest number of underground mines are near the middle of the Appalachian Mountains. As of the late 1990s, Virginia, West Virginia and Kentucky all had over 100 underground mines, and Pennsylvania was not far behind. ${ }^{120}$ However, the largest coal mines in terms of coalbed methane production tend to be found in western states like Colorado, Wyoming and New Mexico. Overall, only 16 of the 48 continental states have underground coalmines, and most of them contain less than 10 mines.

In the EPA's 1997 report, Identifying Opportunities for Methane Recovery at U.S. Coal Mines, profiles of selected gassy underground coal mines were presented, which included information on coal and methane production, as well as electric demand and potential capacity for certain mines. Using this data, it was found that on average, about 1 million cubic feet per day of methane is produced for every million tons of coal per year, and this much methane could potentially produce $1.5 \mathrm{MW}$ of electricity. ${ }^{121}$

The U.S. Energy Information Administration has been keeping track of coalbed methane production and the estimated amount of CBM reserves at U.S. coal mines. The five states producing the most coalbed methane (as of 2007) are: Colorado, Wyoming, New Mexico, Alabama and Virginia. These states also have the highest estimates of coalbed methane reserves, which can potentially be tapped in the future. Table 13 summarizes the total production and reserves for U.S. coal mines.

\footnotetext{
${ }^{120}$ U.S. Environmental Protection Agency, Identifying Opportunities for Methane Recovery at U.S. Coal Mines. 1997. ${ }^{121}$ Ibid.
} 
Table 13. Coalbed Methane Annual Production and Future Reserves, by State

\begin{tabular}{|l|r|r|}
\cline { 2 - 3 } \multicolumn{1}{c|}{} & \multicolumn{2}{c|}{ Coalbed Methane, Billion Cubic Feet } \\
\hline State & Annual Production & Future Reserves \\
\hline Alabama & 114 & 2,127 \\
\hline Colorado & 519 & 7,869 \\
\hline New Mexico & 395 & 4,169 \\
\hline Utah & 73 & 922 \\
\hline Wyoming & 401 & 2,738 \\
\hline Virginia & 85 & 1,948 \\
\hline $\begin{array}{l}\text { Other Eastern States (IL, } \\
\text { IN, OH, PA, WV) }\end{array}$ & 31 & 393 \\
\hline $\begin{array}{l}\text { Other Western States (AR, } \\
\text { KS, LA, MT, OK) }\end{array}$ & 136 & 1,709 \\
\hline Total (All U.S.) & $\mathbf{1 , 7 5 4}$ & $\mathbf{2 1 , 8 7 5}$ \\
\hline
\end{tabular}

Source: Energy Information Administration, Coalbed Methane Proved Reserves and Production

It should be noted, however, that the majority of this methane is from ventilation emissions, which is a dilute air mixture. Only about 17 percent of coalbed methane emissions are collected from surface mining, while 10 percent is collected post-mining, and both of these sources produce the high-quality CBM that can be used as a natural gas substitute. ${ }^{122}$ So about 27 percent of all coalbed methane could be used for CHP projects, leaving 474 billion cubic feet of fuel-grade CBM.

Coalbed methane production is concentrated in relatively few states, so the market is fairly limited. The remote location of most coal mines further complicates potential CHP projects. Despite its desirable fuel properties, using coalbed methane for CHP can be economically challenging, due to difficulties finding a nearby host for heat and power. Meanwhile, more applications are being found for selling treated (or blended) coalbed methane as a natural gas substitute. According to the U.S. Emissions Inventory from 1990-2009, nearly all coalbed methane that has been captured and used from active U.S. mines has been injected into the natural gas pipeline system. ${ }^{123}$ Lower concentrations of methane (below 92 percent) may be less marketable as natural gas and could be a potentially better option for CHP.

Using the estimates for annual fuel-grade CBM production (474 billion cubic feet per year), and assuming 30 percent electric efficiency and 6,000 operating hours on average, approximately $6.9 \mathrm{GW}$ of generating capacity could be fueled from underground coalmines participating in CBM energy projects. Assuming typical CHP efficiencies and a 6,000 hour operating year, about 188 million MMBtu of thermal energy could be utilized with CHP. However, many of these mines are already selling their CBM as a natural gas substitute, and their remote locations (and lack of on-site demand) would severely limit the CHP potential. Coalbed methane does not currently appear to be a very promising fuel for CHP.

\footnotetext{
${ }^{122}$ U.S. Environmental Protection Agency, U.S. Emissions Inventory, 1990-2009, 2009 US Coalbed Methane Emissions.

${ }^{123}$ U.S. Environmental Protection Agency, U.S. Greenhouse Gas Inventory Report Archive, http://www.epa.gov/climatechange/ghgemissions/usinventoryreport/archive.html
} 


\subsection{FOREST RESIDUES}

A 2005 biomass availability study conducted by the National Renewable Energy Laboratory estimated the total amount of forest residues available in each state. ${ }^{124}$ A more recent report, the 2011 Billion Ton Update, provides estimates for quantities of forest residues available at certain price points, which will be taken into consideration in the economic analysis. ${ }^{125}$ However, the NREL data for available resources provided the most comprehensive availability estimate for total forest residues on a state-level basis.

The Southeast states have the largest quantities of forest residues available for consumption. Alabama, Arkansas, Georgia, Kentucky, Louisiana, Mississippi, North Carolina and Virginia all have the potential to produce over 2 million tons of forest residues each year. Maine, Minnesota, Texas and Wisconsin are also capable of producing this amount. Several more states throughout the country could produce over 1 million tons of harvested wood. All of these states would be prime candidates for marketing harvested wood as a biomass fuel. While there could be some variation in heating content depending on the type of wood and the moisture it contains, for this analysis, it is assumed that all wood fuels are sufficiently dried with an average heat content of 7,500 Btu/lb. While many of the trees in the Northwest (and other areas) are softwood conifers with a lower Btu content, the logging industry primarily uses hardwoods, so there should not be a significant regional variation in forest residue heat content. For a breakdown of forest residue availability for each state, see Figure 22 and Table 14. Included in the table is an estimated potential MW capacity for each state, assuming a heat content of 7,500 Btu/lb, a 6,000-hour operating year, and a 30 percent electric efficiency.

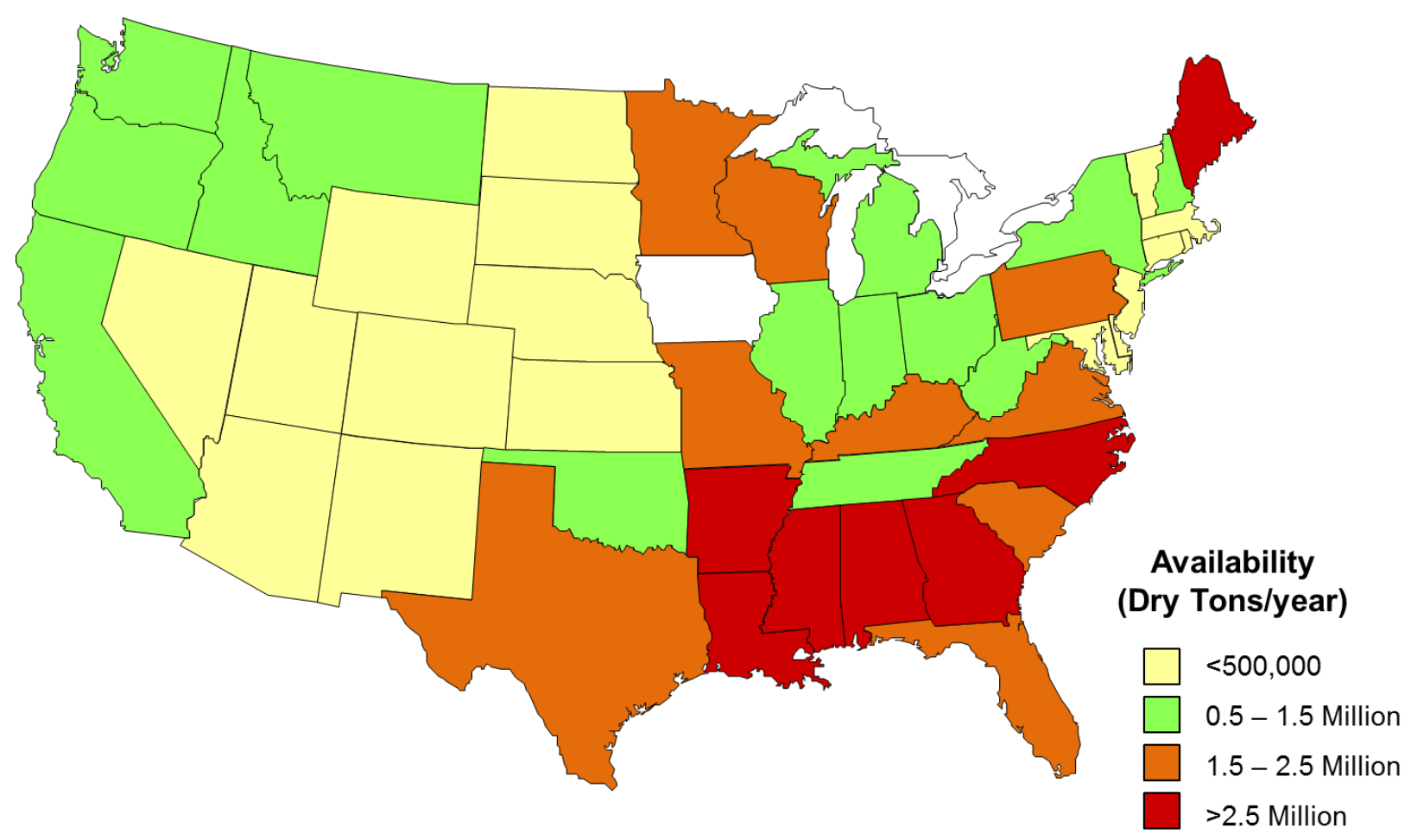

Figure 22. . Forest Residue Fuel Availability By State

\footnotetext{
${ }^{124}$ Milbrandt, A., United States Department of Energy, Technical Report, A Geographic Perspective on the Current Biomass Resource Availability in the United States, National Renewable Energy Laboratory, December 2005.

${ }^{125}$ United States Department of Energy, U.S. Billion Ton Update: Biomass Supply for a Bioenergy and Bioproducts Industry, August 2011.
} 
Table 14. Forest Residue Availability and Technical Potential

\begin{tabular}{|c|c|c|}
\hline State & $\begin{array}{l}\text { Forest Residues } \\
\text { (Thousand Dry Tons) }\end{array}$ & $\begin{array}{l}\text { Potential } \\
\text { Capacity, MW }\end{array}$ \\
\hline Alabama & 2,555 & 557 \\
\hline Arizona & 59 & 13 \\
\hline Arkansas & 2,874 & 626 \\
\hline California & 1,303 & 284 \\
\hline Colorado & 70 & 15 \\
\hline Connecticut & 78 & 17 \\
\hline Delaware & 51 & 11 \\
\hline Florida & 1,778 & 387 \\
\hline Georgia & 3,556 & 775 \\
\hline Idaho & 873 & 190 \\
\hline Illinois & 664 & 145 \\
\hline Indiana & 863 & 188 \\
\hline lowa & 359 & 78 \\
\hline Kansas & 134 & 29 \\
\hline Kentucky & 2,055 & 448 \\
\hline Louisiana & 3,384 & 737 \\
\hline Maine & 2,890 & 630 \\
\hline Maryland & 263 & 57 \\
\hline Massachusetts & 89 & 19 \\
\hline Michigan & 1,275 & 278 \\
\hline Minnesota & 2,242 & 488 \\
\hline Mississippi & 3,825 & 833 \\
\hline Missouri & 1,840 & 401 \\
\hline Montana & 704 & 153 \\
\hline Nebraska & 72 & 16 \\
\hline Nevada & 5 & 1 \\
\hline New Hampshire & 986 & 215 \\
\hline New Jersey & 29 & 6 \\
\hline New Mexico & 71 & 15 \\
\hline New York & 1,111 & 242 \\
\hline North Carolina & 2,995 & 653 \\
\hline North Dakota & 27 & 6 \\
\hline Ohio & 796 & 173 \\
\hline Oklahoma & 655 & 143 \\
\hline Oregon & 1,041 & 227 \\
\hline Pennsylvania & 1,679 & 366 \\
\hline Rhode Island & 8 & 2 \\
\hline South Carolina & 1,733 & 378 \\
\hline South Dakota & 125 & 27 \\
\hline Tennessee & 1,319 & 287 \\
\hline Texas & 2,060 & 449 \\
\hline Utah & 30 & 7 \\
\hline Vermont & 496 & 108 \\
\hline Virginia & 2,403 & 524 \\
\hline Washington & 1,034 & 225 \\
\hline West Virginia & 1,347 & 293 \\
\hline Wisconsin & 2,011 & 438 \\
\hline Wyoming & 58 & 13 \\
\hline U.S. Total & 55,875 & 12,173 \\
\hline
\end{tabular}

Source: National Renewable Energy Laboratory, 2005 
With over 55 million tons of harvested wood reserves available each year, there is the potential for 12 GW of electric capacity and 300 million MMBtu of thermal energy from forest residues. However, at the current rate, the delivered cost averages $\$ 40-\$ 50$ per ton (about \$3.00 per MMBtu), significantly more expensive than coal in most locations. The lack of a market infrastructure and expensive transportation costs hinder extensive fuel use, and has tended to keep it limited to niche applications located close to the source of forest residues.

\subsection{LANDFILL GAS}

Like municipal wastewater treatment plants, the presence of landfills is generally population-based. However, landfills are usually located far away from major cities and populated areas. The Environmental Protection Agency's Landfill Methane Outreach Program (LMOP) maintains a database that documents landfills in the United States, along with their landfill gas project status (Operational, Construction, Shut Down, Candidate or Potential). Landfills listed as potential or candidate were considered to be potential sites for new LFG CHP applications. Most of these sites contain a value for "waste in place", which shows how many tons of waste are currently stored at the landfill. For sites missing this information, the median waste in place for landfills not participating in LFG projects (about $1,000,000$ tons) was used. Using an estimated ratio given by the EPA that correlates waste in place to LFG flow rate, and converting that flow rate into an electric capacity (assuming 30\% efficiency), an estimated potential MW for each state was calculated.

In some cases, the candidate or potential sites have LFG energy projects currently underway or in the planning process. However, there could still be excess LFG at these sites. For these situations, the estimated LFG flow rate to the projects is subtracted from the total LFG produced at the landfill. This process was performed for all of the candidate and potential landfills in the continental United States. California, Florida, Georgia, Illinois, New York, Ohio, Pennsylvania and Texas are the most promising states for new LFG projects, each with over $100 \mathrm{MW}$ of estimated potential. For a breakdown of each state's estimated potential capacity, see Figure 23 and Table 15.

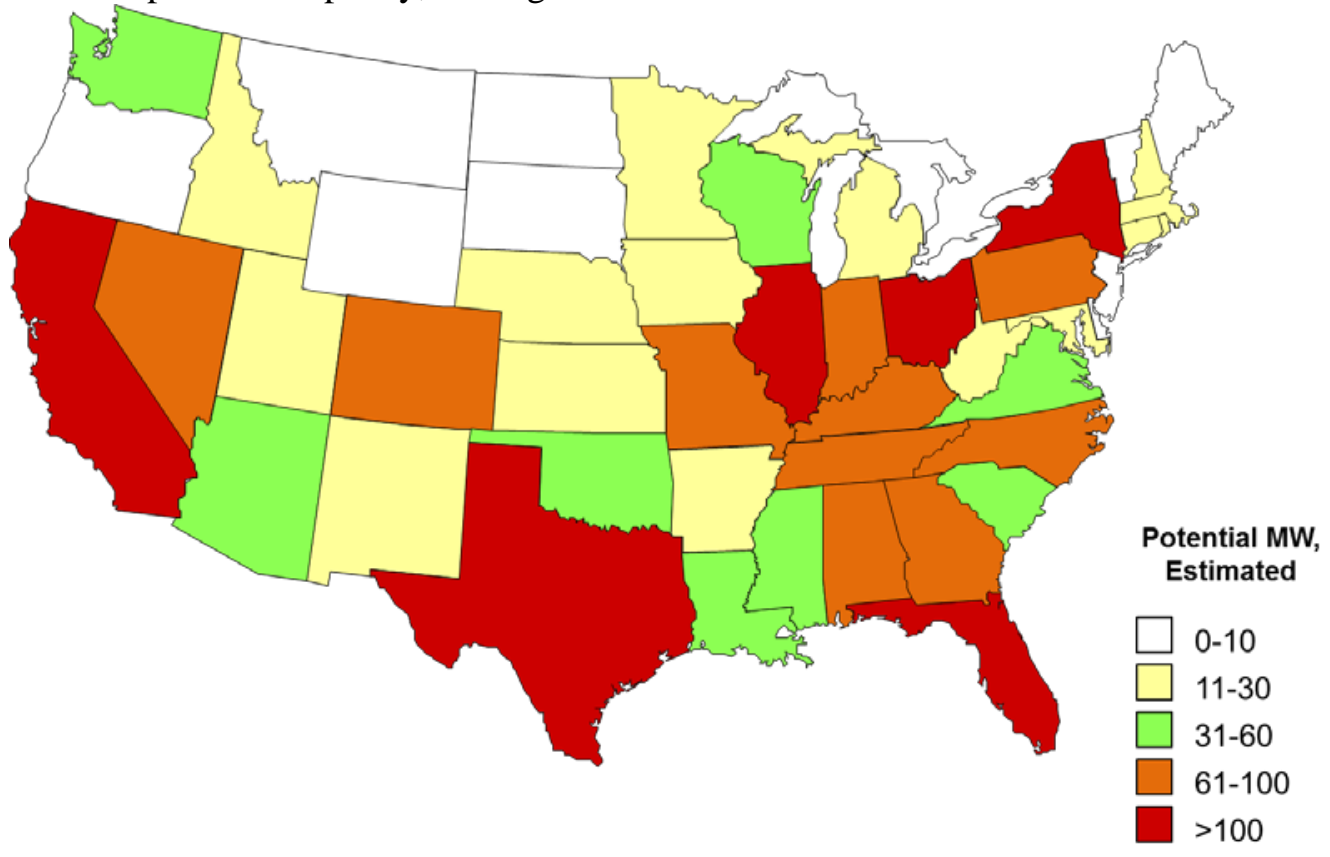

Figure 23. Estimated Potential Capacity for New LFG Projects, By State 
Table 15. Potential Projects and Capacity for New LFG Projects, by State

\begin{tabular}{|c|c|c|c|}
\hline State & $\begin{array}{c}\text { Candidate \& } \\
\text { Potential } \\
\text { Landfills } \\
\end{array}$ & $\begin{array}{c}\text { Estimated LFG } \\
\text { Flow Rate } \\
\text { (CFM) } \\
\end{array}$ & $\begin{array}{c}\text { Estimated } \\
\text { Potential } \\
(\mathrm{MW}) \\
\end{array}$ \\
\hline Alabama & 34 & 25,872 & 68 \\
\hline Arkansas & 21 & 8,792 & 23 \\
\hline Arizona & 25 & 17,331 & 46 \\
\hline California & 246 & 110,963 & 342 \\
\hline Colorado & 28 & 29,487 & 81 \\
\hline Connecticut & 20 & 5,495 & 14 \\
\hline Delaware & 2 & 1,800 & 7 \\
\hline Florida & 53 & 41,095 & 127 \\
\hline Georgia & 60 & 31,538 & 86 \\
\hline lowa & 25 & 8,682 & 23 \\
\hline Idaho & 28 & 7,838 & 21 \\
\hline Illinois & 51 & 41,180 & 110 \\
\hline Indiana & 76 & 28,644 & 78 \\
\hline Kansas & 29 & 9,203 & 24 \\
\hline Kentucky & 32 & 23,212 & 61 \\
\hline Louisiana & 31 & 13,380 & 35 \\
\hline Massachusetts & 23 & 9,116 & 24 \\
\hline Maryland & 33 & 11,077 & 29 \\
\hline Maine & 9 & 1,674 & 5 \\
\hline Michigan & 10 & 3,739 & 11 \\
\hline Minnesota & 23 & 8,193 & 22 \\
\hline Missouri & 93 & 23,573 & 62 \\
\hline Mississippi & 25 & 18,846 & 50 \\
\hline Montana & 3 & 2,470 & 7 \\
\hline North Carolina & 110 & 33,248 & 90 \\
\hline North Dakota & 21 & 738 & 2 \\
\hline Nebraska & 21 & 5,577 & 15 \\
\hline New Hampshire & 20 & 7,165 & 19 \\
\hline New Jersey & 7 & 2,560 & 8 \\
\hline New Mexico & 6 & 5,850 & 15 \\
\hline Nevada & 10 & 22,391 & 70 \\
\hline New York & 58 & 55,223 & 182 \\
\hline Ohio & 44 & 45,237 & 120 \\
\hline Oklahoma & 20 & 14,697 & 39 \\
\hline Oregon & 6 & 2,129 & 6 \\
\hline Pennsylvania & 36 & 24,445 & 66 \\
\hline Rhode Island & 4 & 720 & 11 \\
\hline South Carolina & 37 & 15,220 & 47 \\
\hline South Dakota & 8 & 1,812 & 5 \\
\hline Tennessee & 123 & 28,073 & 77 \\
\hline Texas & 88 & 83,133 & 230 \\
\hline Utah & 46 & 6,639 & 18 \\
\hline Virginia & 41 & 19,075 & 54 \\
\hline Vermont & 5 & 1,050 & 4 \\
\hline Washington & 46 & 17,333 & 40 \\
\hline Wisconsin & 33 & 11,862 & 32 \\
\hline West Virginia & 19 & 8,837 & 23 \\
\hline Wyoming & 3 & 2,408 & 6 \\
\hline U.S. Totals & 1792 & 898,621 & 2,537 \\
\hline
\end{tabular}

Source: EPA LMOP Database, 2011: http://www.epa.gov/lmop/proj/index.htm\#1 
According to the EPA's latest Landfill Methane Outreach Program Database, there are 646 operational LFG projects, along with several more projects currently under construction. However, some landfills contain multiple projects, and 477 of them produce electricity, while the rest are thermal applications. The total capacity for LFG-electricity projects is $1.6 \mathrm{GW}$, although not all sites have data for electric capacity. It is estimated that all of the 646 current LFG to energy projects could produce a total of $4.8 \mathrm{GW}$ if they were generating electricity at full capacity. With $2.8 \mathrm{GW}$ of capacity from Candidate and Potential landfills, the total technical potential for landfill gas is $7.6 \mathrm{GW}$, minus the $1.6 \mathrm{GW}$ already being produced, or $6 \mathrm{GW}$ of technical potential for new LFG energy projects. The corresponding thermal output would be about 160 million MMBtu/year, assuming an average of 6,000 full-load hours of operation.

\subsection{TIRE-DERIVED FUEL}

Although the exact number of tires available for tire-derived fuel in each state is uncertain, there are some regional differences that affect the supply. States with higher populations tend to produce more waste tires, but they are not always stockpiled or stored in-state. Some smaller states like Indiana and Ohio contain large stockpiles of tires from various states in the general vicinity. Some states have experimented with government subsidies that encourage scrap tire utilization. This tends to result in increased TDF utilization for these states. It also results in nearby states importing scrap tires at the subsidized rate for their own tire-derived fuel projects. However, many state subsidies for scrap tire utilization do not include tire-derived fuel as a potential end-use because of air quality issues.

For example, in the late 1990s, the majority of scrap tires utilized by TDF projects in California were imported from nearby states with subsidies. As a consequence, ninety percent of California's scrap tires were stockpiled instead of utilized, and the tires used for TDF projects came mostly from Arizona, Oregon, and Washington. ${ }^{126}$ Oregon and Washington have since terminated their TDF programs, and while several states offer subsidies for scrap tire utilization, Virginia and Ohio are the only ones known to have currently existing TDF subsidies, with Virginia offering \$22.50 per ton as a reimbursement.

Aside from state subsidies, the number of tires stockpiled and the current levels of TDF utilization are the determining factors in a state's tire-derived fuel availability. States with cement kilns and pulp and paper mills are most likely to already utilize a large amount of TDF. At the end of 2005, 58 million tires were consumed in the United States by a total of 17 cement companies in a total of 78 cement kilns, at 47 different facilities. At pulp and paper mills, 39 million scrap tires were consumed in 2005 by 24 different mills, up from 26 million scrap tires at 17 mills in 2003. Additionally, 16 industrial boilers and 17 electric utilities consumed the equivalent of 48 million scrap tires in $2005 .^{127}$ Finally, two dedicated tiresto-energy projects use about 11 million tires each year. These TDF utilization trends are summarized in Figure 24.

\footnotetext{
${ }^{126}$ Scrap Tire Management Council, Scrap Tire Use/Disposal Study, Washington, DC, 1997.

${ }^{127}$ Scrap Tire Markets in the United States. 2005 Edition, Rubber Manufacturers Association, November 2006.
} 


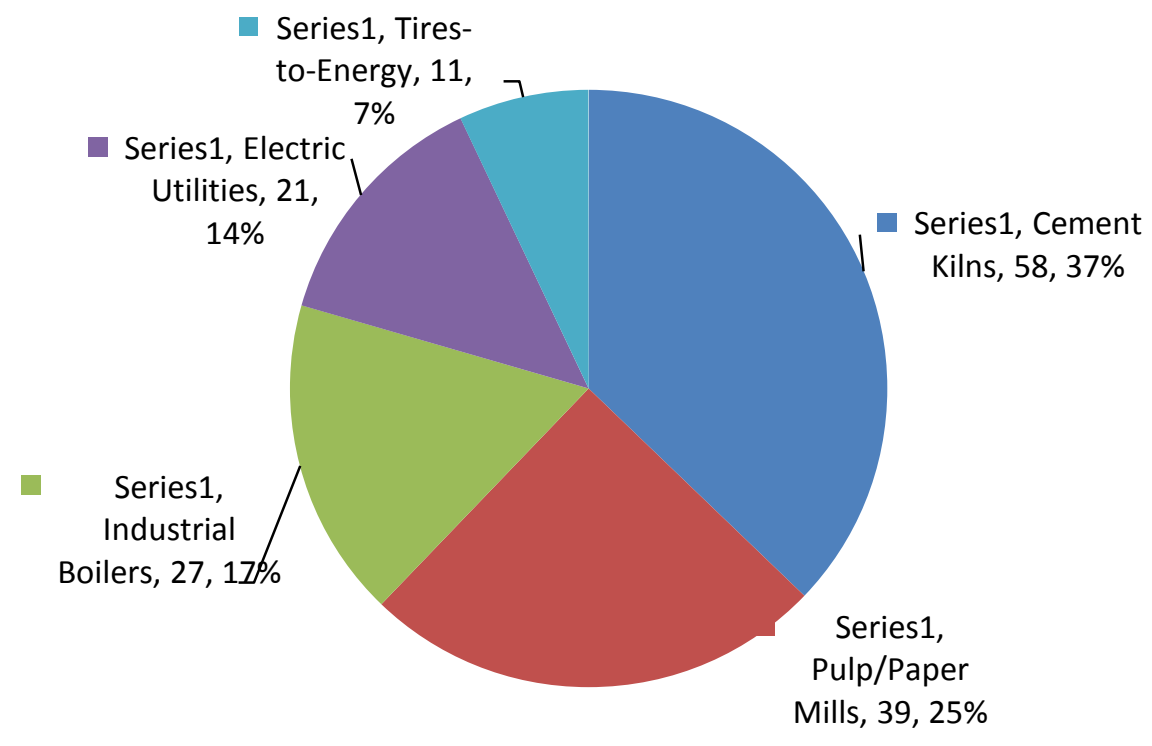

Figure 24. Recent Markets for TDF Utilization

Overall, an estimated 150 million tires are used as fuel each year, compared to roughly 300 million scrap tires that are discarded annually in the country. The majority of the other tires are used for ground rubber or civil engineering applications, while a large amount are landfilled. For facilities located close to existing TDF users, the local supply of TDF could be constrained. Alternatively, the presence of these facilities could indicate nearby sources of scrap tires and TDF processing plants.

The TDF market can also be affected by what other fuel sources are locally available to industrial sites. In the Northwest, where there is a relatively abundant supply of low cost petroleum coke, the demand for TDF at pulp and paper mills is practically non-existent. At present, no Northwest pulp and paper mills use TDF, and this is not expected to change in the foreseeable future. ${ }^{128}$ Similarly, wood processing facilities that have a cheap source of wood waste fuel would be less inclined to incorporate TDF into their plant operations. Still, there are numerous industrial facilities with coal boilers that could potentially switch to TDF. The availability of scrap tires is a primary driver for TDF markets, and is generally the best indicator of where TDF utilization can be realized.

According to the Rubber Manufacturers Association, approximately 112 million scrap tires remained in stockpiles in 2010, down from over 1 billion in $1990 .{ }^{129}$ State efforts to abate stockpiled tires and develop sustainable scrap tire markets have led to this reduction. For example, as of the late 1990s, Ohio, Maine, California, Louisiana, Rhode Island, Illinois and Indiana accounted for 40 percent of the nation's stockpiled tires ${ }^{130}$, but at the end of 2005, these states accounted for less than 15 percent. However, not all states have been actively reducing their stockpiles. Seven states that accounted for less than 30 percent of stockpiled tires in the late 1990s combined for 85 percent of the nation's remaining scrap tire stockpiles at the end of $2007 .{ }^{131}$

\footnotetext{
128 Ibid.

${ }^{129}$ U.S. Scrap Tire Management Summary 2005-2009, Rubber Manufacturer’s Association, October 2011.

${ }^{130}$ Scrap Tire Management Council, Scrap Tire Use/Disposal Study, Washington, DC, 1997.

${ }^{131}$ Scrap Tire Markets in the United States: $9^{\text {th }}$ Biennial Report, Rubber Manufacturers Association, May 2009.
} 


\section{States With Most Stockpiled Tires:}

- Alabama

- Arizona

- Colorado

- Connecticut

- Michigan

- New York

- Texas

The states with the largest stockpiles could be good candidates for near-term TDF projects, but the sustainable use of TDF requires newly discarded tires, and there are about 300 million tires discarded in the United States each year (close to twice the amount currently stockpiled). Each tire is equivalent to about 2.5 barrels of fuel oil according to heat content, meaning each tire contains about 340,000 Btu. If the 300 million tires discarded each year were used for fuel, the total electric generation capacity would be just over $1 \mathrm{GW}$. However, the actual potential for new tire-derived fuel CHP projects is much lower, as there are many useful products that are currently being manufactured from recycled tires. Only about half of the scrap tires in the U.S. are available for TDF utilization, and most of this potential is already being realized.

In 2007, the Rubber Manufacturers Association estimated that by weight, 89 percent out of nearly 5 million tons of scrap tires generated (about 300,000 tires) were either recycled or utilized for fuel in various end-use markets. ${ }^{132}$ Assuming the same recycle/utilization rate applies to present day, about 33 million tires per year should be available for new TDF projects. This amount of tires has the technical potential to reach $112 \mathrm{MW}$ of new generation capacity, with the potential for CHP units to meet about 4 million MMBtu/year of thermal demand. In addition to a relatively small total technical potential and limited availability in most states, there are some issues with using tire-derived fuel for electricity generation, which will be further explored in the next chapter.

\subsection{WOOD WASTE (URBAN WOOD WASTE)}

Urban wood waste is a very broad fuel category, and can consist of yard trimmings, wood pallets, construction and demolition waste, and other forms of wood waste. These waste products are typically either landfilled or hauled to wood recycling centers, where they can be processed into wood chips that could potentially be used for fuel. The National Renewable Energy Laboratory biomass availability study estimated the amount of urban wood waste available for each state, primarily from wood recycling yards and municipal yard waste processing sites. ${ }^{133}$ The earlier Oak Ridge National Laboratory study also estimated the amount of biomass available in each state within certain price ranges. The average price remained consistent from state to state, at 18-20 dollars per dry ton ${ }^{134}$, although current transportation costs likely put delivered costs closer to $\$ 30 /$ ton. The availability of fuel resources, however, changes drastically with each state and region.

\footnotetext{
132 Ibid.

${ }^{133}$ Milbrandt, A. A Geographic Perspective on the Current Biomass Resource Availability in the United States. United States Department of Energy, National Renewable Energy Laboratory. Technical Report. December 2005.

${ }^{134}$ Biomass Feedstock Availability in the United States: 1999 State-Level Analysis. United States Department of Energy, Oak Ridge National Laboratory. Updated January 2000. http://bioenergy.ornl.gov/resourcedata/index.html
} 
Another type of wood waste is mill residue, which is produced at pulp/paper mills and wood processing facilities. This waste is essentially free to the producer, and is most often utilized by these facilities in one way or another. CHP applications are becoming more common, but boiler fuel is the most common use for mill residues at these facilities. Typically, the vast majority of mill waste produced at a given facility is already used for process heating or boiler applications. The NREL study estimated that there are approximately 1.6 million tons of primary mill residues in the United States available each year, while there is over 30 million tons of urban wood waste. Because of this disparity, and the fact that significant quantities of mill residues are unlikely to be found at a given industrial site, urban wood waste is the only source of wood waste fuel considered for the analysis. Urban wood waste has the potential to be marketable in applications where coal-fired boilers are used, for three reasons: 1 ) its price is usually significantly less than coal, 2) it is not an industrial byproduct, so there is no facility with privileged access to the waste, and 3) it is available in large quantities in every state.

Because urban wood waste comes from a variety of different sources, the heat content of the fuel can vary considerably. Most sources of urban wood waste produce a dried fuel with a heat content of 6,000-7,500 Btu/lb, but urban brush and tree clearings (which typically contain more moisture and less woody biomass) tends to produce fuel with a heat content of only 4,000-5,000 Btu/lb. ${ }^{135}$ For the purposes of this report, an average heating value of 6,500 Btu/lb is assumed for all urban wood waste fuels.

The largest markets for urban wood waste exist in California, Texas, New York and Florida, which are the most highly populous states. All of these states produce over 1.5 million dry tons of urban wood waste each year. Illinois, Ohio, Michigan and Pennsylvania each produce over 1 million tons each year, and could also make great markets for the fuel. For a breakdown of urban wood waste availability for every state, see Figure 25 and Table 16 . Included in the table is an estimated potential capacity for each state, assuming 6,500 Btu/lb, 30 percent efficiency, and a 6,000-hour year.

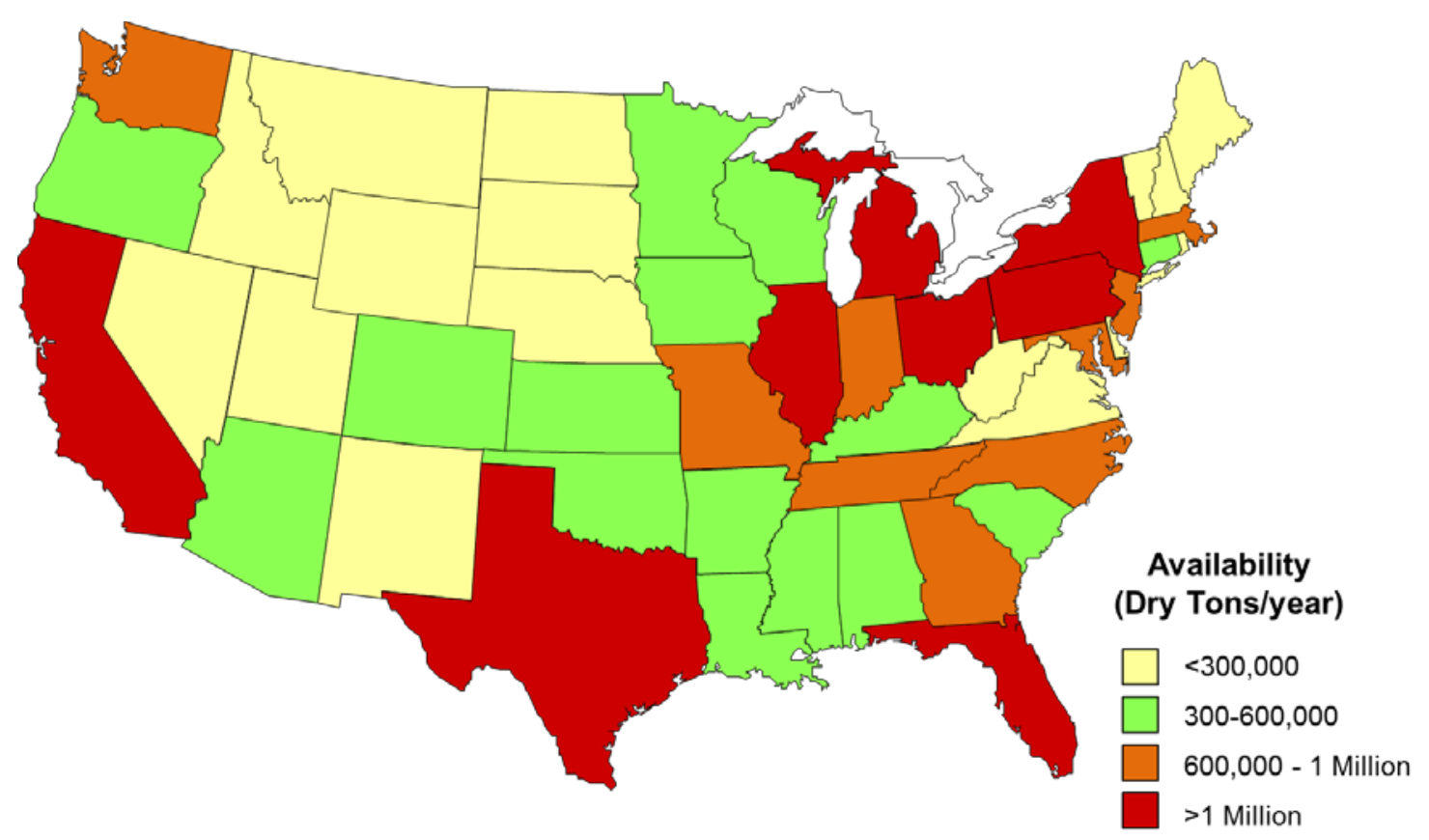

Figure 25. Urban Wood Waste Availability By State

\footnotetext{
${ }^{135}$ Study of Processing and Utilizing Urban Wood Waste and Pallets for Fuel in the State of Illinois. M.L. Smith Environmental, Inc. and Associates, prepared for Council of Great Lakes Governors Regional Biomass Energy Program. January 1995.
} 
Table 16. Urban Wood Waste Availability and Technical Potential

\begin{tabular}{|c|c|c|}
\hline State & \begin{tabular}{|c|} 
Urban Wood Waste \\
$(1,000$ dry tons, annual)
\end{tabular} & \begin{tabular}{|c} 
Potential Capacity \\
(MW)
\end{tabular} \\
\hline Alabama & 483 & 92 \\
\hline Arizona & 526 & 100 \\
\hline Arkansas & 314 & 60 \\
\hline California & 3,901 & 743 \\
\hline Colorado & 451 & 86 \\
\hline Connecticut & 376 & 72 \\
\hline Delaware & 85 & 16 \\
\hline Florida & 1,678 & 320 \\
\hline Georgia & 924 & 176 \\
\hline Idaho & 129 & 25 \\
\hline Illinois & 1,337 & 255 \\
\hline Indiana & 715 & 136 \\
\hline lowa & 320 & 61 \\
\hline Kansas & 332 & 63 \\
\hline Kentucky & 454 & 86 \\
\hline Louisiana & 474 & 90 \\
\hline Maine & 133 & 25 \\
\hline Maryland & 624 & 119 \\
\hline Massachusetts & 687 & 131 \\
\hline Michigan & 1,196 & 228 \\
\hline Minnesota & 496 & 94 \\
\hline Mississippi & 307 & 58 \\
\hline Missouri & 613 & 117 \\
\hline Montana & 106 & 20 \\
\hline Nebraska & 189 & 36 \\
\hline Nevada & 232 & 44 \\
\hline New Hampshire & 126 & 24 \\
\hline New Jersey & 894 & 170 \\
\hline New Mexico & 191 & 36 \\
\hline New York & 2,041 & 389 \\
\hline North Carolina & 833 & 159 \\
\hline North Dakota & 67 & 13 \\
\hline Ohio & 1,272 & 242 \\
\hline Oklahoma & 377 & 72 \\
\hline Oregon & 382 & 73 \\
\hline Pennsylvania & 1,238 & 236 \\
\hline Rhode Island & 109 & 21 \\
\hline South Carolina & 467 & 89 \\
\hline South Dakota & 75 & 14 \\
\hline Tennessee & 614 & 117 \\
\hline Texas & 2,307 & 439 \\
\hline Utah & 228 & 43 \\
\hline Vermont & 65 & 12 \\
\hline Virginia & 813 & 155 \\
\hline Washington & 675 & 129 \\
\hline West Virginia & 184 & 35 \\
\hline Wisconsin & 548 & 104 \\
\hline Wyoming & 59 & 11 \\
\hline Total & 30,647 & 5,838 \\
\hline
\end{tabular}

Source: National Renewable Energy Laboratory, 2005 
Although physical properties are similar, urban wood waste is very different than harvested wood fuel. In many cases, the transportation and processing costs are less, since the waste is already being collected and hauled to wood recycling plants. As a result, urban wood waste is generally less expensive to purchase. On the negative side, the wood usually contains more impurities from paint and protective coatings, so equipment and maintenance costs can be affected. There are a number of industrial plants already utilizing their wood wastes, and many more with the potential to do so, although these wastes usually fall under the mill residue category. Urban wood waste, however, would require a market infrastructure for gathering, processing and selling the fuel. Currently most waste is hauled to recycling yards, and some of these facilities do produce wood waste boiler fuel, but the market would need to drastically expand for urban wood waste to become a major player in the industry.

The total annual United States urban wood waste reserves are estimated to be 30,647,000 tons. At 6,500 Btu/lb, this could provide close to $6 \mathrm{GW}$ of electricity and 175 million MMBtu of thermal energy each year. With delivered prices in the range of \$1.50-\$2.50 per MMBtu, urban wood waste could be very competitive with coal as a solid boiler fuel.

\subsection{CHAPTER 4 SUMMARY}

The availability of the six fuels in each state has been analyzed, but there are certain things one must keep in mind with this analysis. The states' size and population were not taken into account, and this can skew the perception of market potential. While a state may have a large amount of reserves, the market potential is limited if the population is scarce, as is the case in the Midwest. Also, larger states can appear to have greater reserves compared to smaller states, but they could really have a lower density per unit area. These issues should always be considered when analyzing the market potential of a state from the given availability data. Regardless, the data is a good indicator to where the best resources and markets are for each of opportunity fuels.

In examining each fuel's availability and technical potential, it is apparent that each of the chosen opportunity fuels has a very strong potential for use. While coalbed methane and, to a lesser extent, forest residues are only available in certain regions, the amount available in these regions is abundant. Anaerobic digester gas, landfill gas, tire-derived fuel, and wood waste, although sometimes concentrated in more populated regions, are generally ubiquitous throughout the continental U.S., so regional availability for these fuels is not an issue. Although in some cases the actual potential capacity is probably much less than the technical, all of the opportunity fuels in this section are capable of producing a good deal of power. 
The estimated thermal and electric capacities, in annual trillion Btu and GW, are given for each fuel in Table 17. These values are technical potential, meaning the maximum possible potential if all available resources are utilized.

Table 17. Estimated Potential Thermal and Electric Capacity for the Opportunity Fuels

\begin{tabular}{|l|c|c|}
\hline \multicolumn{1}{|c|}{ Fuel } & $\begin{array}{c}\text { Potential Thermal } \\
\text { Energy } \\
\text { (Estimated, } \\
\text { Million MMBtu/yr) }\end{array}$ & $\begin{array}{c}\text { Potential Electric } \\
\text { Capacity } \\
\text { (Estimated, GW) }\end{array}$ \\
\hline Anaerobic Digester Gas & 150 & 5.3 \\
\hline Coalbed Methane & 188 & 6.9 \\
\hline Forest Residues & 300 & 12 \\
\hline Landfill Gas & 160 & 0.1 \\
\hline Tire-Derived Fuel & 4 & 6 \\
\hline Urban Wood Waste & 175 & $\mathbf{3 6}$ \\
\hline TOTALS & $\mathbf{9 7 7}$ & \\
\hline
\end{tabular}

If all potential resources were utilized for these seven fuels, the total technical potential would be 977 million MMBtu of thermal output, with over $36 \mathrm{GW}$ of electric capacity. However, only a small fraction of this technical potential is likely to be realized, due to constraints such as investment returns and finding suitable hosts for electrical and thermal output. In the next chapter, the current status and future outlook of each fuel is thoroughly examined to paint a more realistic picture of the actual project potential for the fuels. Then, the most promising fuels are chosen for detailed market analyses with a consideration of economic issues using the DISPERSE model. 



\section{CURRENT PROJECTS AND FUTURE PROSPECTS}

While the availability of a fuel's resources is critical, it is not alone sufficient to ensure that opportunity fuels can be effectively utilized for CHP. In this section, current and future opportunity fuel projects are examined to review how each fuel is being used and if there are any potential barriers, limitations, and/or drawbacks to their use. Some of the chosen opportunity fuels, such as anaerobic digester gas, landfill gas, biomass and wood waste are widely used with growing acceptance in the CHP marketplace. Other fuels like coalbed methane are rarely ever used for CHP because of low on-site electric and thermal demands. Tire-derived fuel and harvested wood, on the other hand, have been mostly limited to large industrial heating applications, including some that use CHP. This section examines these issues to further define the potential market and determine which fuels should be evaluated for economic market potential.

\subsection{ANAEROBIC DIGESTER GAS}

Wastewater treatment plants have been utilizing anaerobic digester gas for energy for many years, but ADG-fueled power generation has only recently become common. In the past, modified natural gas reciprocating engines were primarily used for power generation, although some ADG-powered gas turbines and boiler-steam turbine systems existed. Installations, however, were few and far between and generally limited to larger facilities. With the introduction of microturbines and fuel cells and the push for renewable energy sources, anaerobic digester gas has been receiving more attention. Fuel cells and microturbines can utilize the fuel in small-scale power operations while producing very few emissions, and reciprocating engine lean burn technology has improved their operation as well. In areas where emission regulations are strict, microturbines and fuel cells operating on ADG provide an environmentally sound power source, and state governments have helped to provide crucial funding and project assistance.

Anaerobic digester gas performs very well when thoroughly cleaned of contaminants and impurities, although its heating value remains about half that of natural gas. The main problems facilities with ADG gensets face are the condensation of water inside transport tubes, the occasional dip in digester gas flow rate, particulates, and siloxanes. The water problem can be easily solved with well-placed water traps and a coalescing dryer. For plants that experience lags in their digester gas flow rate, natural gas is often used as a secondary fuel, triggered by a mechanism in dual-fuel burners that senses when the ADG flow rate is too low. Some facilities have installed gas storage as well. Another potential problem is the formation of silicon dioxide from siloxane, a chemical found in shampoo and cosmetics - this can be remedied through various treatment methods. Hydrogen sulfide is another potential contaminant which can be treated with various types of iron filters. ${ }^{136}$

Despite some minor drawbacks, anaerobic digester gas is one of the most promising opportunity fuels, and many wastewater treatment plants have seen positive results with ADG projects. In addition, ADG utilization at WWTPs can easily incorporate CHP, since treatment plants tend to have high electric and thermal demands. To date, there are about 100 municipal wastewater treatment plants known to be utilizing their digester gas for CHP. ${ }^{137}$

\footnotetext{
${ }^{136}$ Other methods for hydrogen sulfide treatment include zeolite, iron chloride added to the digester, or oxygen added to the biogas to promote biological removal.

${ }^{137}$ Opportunities for Combined Heat and Power at Wastewater Treatment Facilities: Market Analysis and Lessons from the Field, U.S. Environmental Protection Agency, Combined Heat and Power Partnership, October 2011.
} 


\subsubsection{Internal Combustion Engines and Turbines}

Several wastewater treatment plants installed internal combustion engines for CHP applications in the late 1970's and 1980's, and most are still in operation. The earliest known plant is the Village Creek Wastewater Treatment Center in Arlington, Texas. They installed two 1.15 MW IC engines in 1977 that run on anaerobic digester gas. Major overhauls have been necessary every 28,000 hours, which is more frequent than natural gas engines. The two IC engines were not utilizing all of the site's potential power, so a gas turbine was installed in 2001 to put the rest of the gas to use. As with most ADG operations, moisture condensation and dips in flow rate have been the only two problems encountered with the fuel. In an interesting twist, instead of using natural gas as a secondary fuel when the flow rate drops too low, gas from a local landfill (LFG) is used for backup, and no major problems have been reported. ${ }^{138}$

The Papillion Creek Wastewater Treatment Center in Bellevue, Nebraska also installed two small IC engines in 1977. The engines worked so well that three more were installed in the mid-80's to supply power for the entire plant. Recently, a sixth engine was installed to keep up with the increased waste flow. All of the engines are designed for CHP and allow for dual-fuel flow so that natural gas can be used when necessary. Typically, only 4 of the 6 engines are running at a given time, so there is no downtime for maintenance or repairs. While water condensation can be a problem when the weather changes, this occurs rarely and is only a minor setback. The plant operations manager stated that significant savings are achieved from utilizing digester gas, and that the facility's power costs would double if the fuel was not used. ${ }^{139}$

The Oxnard Wastewater Treatment Plant in Oxnard, California installed three $500 \mathrm{~kW}$ IC engines for $\mathrm{CHP}$ in 1981. With this plant, $\mathrm{H}_{2} \mathrm{~S}$ formation in the gas was a particular problem. To combat this issue, ferric chloride is added to the waste sludge, effectively preventing the hazardous compound's formation. This treatment works well and is relatively inexpensive, so other wastewater plants have since followed suit. The Oxnard plant uses natural gas as a secondary fuel when the ADG flow rate dips too low, but this occurs very infrequently.

In an example of an industrial wastewater treatment facility utilizing its ADG, the New Belgium Brewery in Fort Collins, Colorado recently installed a $290 \mathrm{~kW}$ CHP engine. The brewery is the seventh-largest in the nation, producing about 530,000 barrels of beer each year. The city of Fort Collins was charging the brewery a "plant investment fee" for all of the high-strength wastewater that the municipal treatment system would have to process. Instead, the brewer decided to build their own treatment plant with anaerobic digestion, using the gas to power the CHP engine. This allowed the company to significantly reduce its peak demand and energy consumption, providing energy cost savings of about \$5,000 a month. ${ }^{140}$ Recovered heat is used to heat the wastewater and maintain the anaerobic digester temperature.

While several other treatment plants are using IC engines and gas turbines, the three plants discussed offer a good view of the overall picture. Combustion engines are more popular than turbines, because there are few treatment plants that can support projects greater than $5 \mathrm{MW}$ in size. Sometimes ADG is used as a boiler fuel, but steam turbine installations are extremely rare. The primary problems that plants experience are moisture and flow-rate related, and both problems can be remedied. Siloxanes and hydrogen sulfide can cause issues for some plants, requiring expensive gas treatment equipment that can hinder project economics. However, most treatment plants are aware of the problems that these contaminants can cause, and any necessary gas cleanup equipment is included in the planning processes.

\footnotetext{
138 Telephone conversation with Village Creek Wastewater Treatment Center engineer, 2005.

${ }^{139}$ Telephone conversation with Papillion Creek Wastewater Treatment Center operations manager, 2005.

${ }^{140}$ United States Department of Energy, Intermountain Clean Energy Application Center, Project Profiles: New Belgium Brewery, updated 2009.
} 


\subsubsection{Fuel Cells and Microturbines}

Fuel cells and microturbines are relatively new technologies, and only recently have they been applied to anaerobic digester gas projects. While more expensive than traditional engines and turbines, they tend to produce very few emissions. Because of this, some states are willing to provide extra funding for fuel cell and microturbine projects, eliminating the cost advantage of the more conventional technologies. The most promising markets for fuel cells and microturbines are states like New York and California with strict emissions regulations, since expensive add-ons may be required for traditional systems, and state governments are more likely to provide incentive funding.

The first ADG fuel cell project occurred at the Yonkers Wastewater Treatment Plant in Yonkers, New York. 1n 1997, a $200 \mathrm{~kW}$ fuel cell was installed, and it was successfully run for several years, providing reliable power to the plant. Similar projects were soon underway in Portland, Oregon and Boston, Massachusetts. The state governments helped fund the projects on a five-year trial period, in an effort to promote this environment-friendly technology. The main problem experienced at these plants, besides excess moisture and occasional dips in flow rate, was the lack of knowledge and experience regarding fuel cell operation and maintenance. Rather than hiring fuel cell experts, the plants opted to train their own workers on how to operate and maintain the machinery. This resulted in a number of errors and problems that could have easily been avoided. Although the lesson has been learned, the Deer Island Wastewater Treatment plant in Boston chose to discontinue fuel cell operations in 2002, after the initial five-year trial period. The Portland plant (the Columbia Boulevard Wastewater Treatment Plant, discussed later in this section) chose to stop operating their fuel cell at about the same time.

Microturbines are less expensive than fuel cells, but they produce more emissions. Still, microturbines are usually easier to permit than conventional engines and turbines, and like fuel cells, state governments have provided critical funding for microturbine projects at municipal wastewater treatment plants. One of the first successful CHP microturbine projects was at the Lewiston Wastewater Treatment Plant in Lewiston, New York. The two $30 \mathrm{~kW}$ microturbines are dual fuel, to allow for natural gas injection during periods of high demand, or when the ADG flow rate is low. The microturbines were installed in 2000, and have remained in steady operation ever since. As with the other technologies, fuel moisture can be a problem, so the gas is thoroughly dried before it is piped to the microturbine. Another problem occurred when siloxane chemicals formed silicon dioxide deposits in the turbine known as "white ash". When the operators noticed this problem, a carbon filter was placed upstream and the deposits have not returned since.

The Columbia Boulevard Wastewater Treatment Plant in Portland, Oregon provides a good example of how excess ADG from a municipal plant can be utilized in a number of different ways. It also shows how government-supported fuel cell and microturbine projects can still fail economically compared to more traditional options. For many years, the Portland plant sold a portion of their digester gas to the nearby Malarkey Roofing Company for boiler fuel (Malarkey installed a mile-long pipeline for this purpose), while the rest of the gas was burned in on-site boilers to heat the digester tanks and buildings. Despite high moisture content of the gas and the presence of hydrogen sulfide and siloxanes, the gas was not cleaned or dried in any way prior to boiler use, although boilers can typically tolerate more contaminants and moisture than CHP units. There was also a surplus of ADG that was simply flared. ${ }^{141}$

\footnotetext{
${ }^{141}$ Telephone conversation with William Park, plant engineer. March 7, 2011.
} 
In 1998, a $200 \mathrm{~kW}$ fuel cell was installed at the Columbia Boulevard treatment plant (see Figure 26) with the help of both state and federal government funding. In 2003, four 30-kW microturbines were added, also receiving some funding from the state of Oregon. The fuel cell proved more expensive to operate than anticipated, and the microturbines experienced problems with water condensation in the combustion area. However, these were primarily demonstration projects, and plant operators found that installing CHP engines would be more economical than using these new technologies, so they installed two $850 \mathrm{~kW}$ engines in 2006. ${ }^{142}$ A gas processing unit removes hydrogen sulfide, halogens and

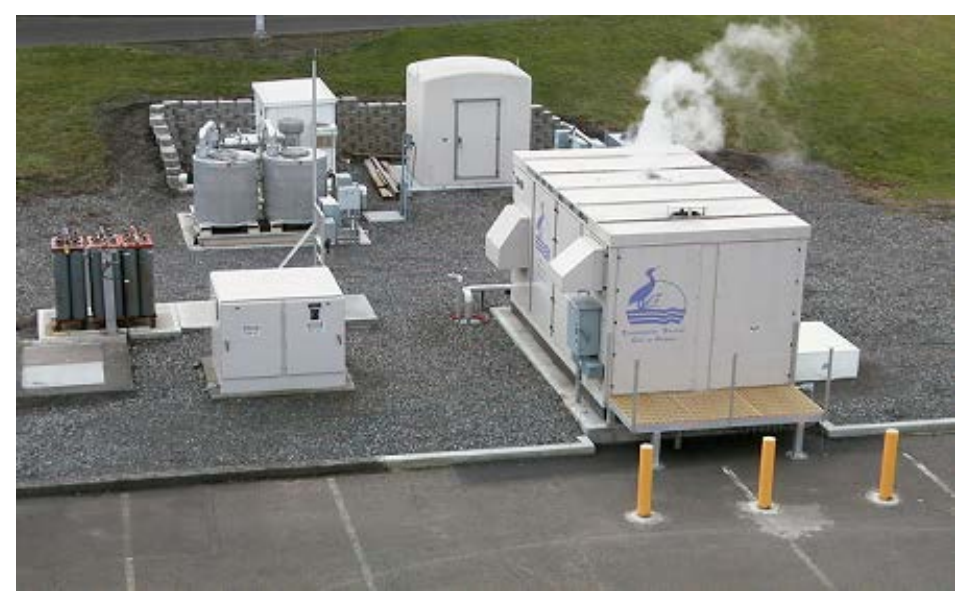

Figure 26. 200 kW ADG Fuel Cell in Portland, Oregon (Source: www.portlandoregon.gov) siloxanes from the ADG so that it can be utilized by the engines, which now provide power and heat for the plant. The facility still uses ADG-fueled boilers (without gas pretreatment) to provide the remainder of heat for all of the buildings, and they still sell about 10 million cubic feet per month to Malarkey Roofing. ${ }^{143}$ Despite high levels of ADG utilization, the plant consistently produces a surplus of gas, which continued to be flared in 2011.

In another example of an ADG fuel cell installation, the Sierra Nevada Brewery in Chico, California installed a 1 MW fuel cell system (four 250 kW Fuel Cell Energy molten carbonate fuel cells) in 2005. The fuel cells originally ran off natural gas, but in late 2006 ADG was integrated, displacing 25-40 percent of natural gas use. However, the brewery ended up switching back to 100 percent natural gas largely because the brewing production schedule did not allow for a steady stream of biogas production. ${ }^{144}$ This could be an issue for other industrial wastewater treatment plants, compared to municipal plants that maintain a steady waste stream.

\subsubsection{Farms}

Aside from wastewater treatment plants, dairy and hog farms have also been targeted as potential sites for anaerobic digesters and a potential source of ADG. Some farms use digesters to control manure odor and emissions, providing opportunities for ADG-fueled CHP. The problem is that most farms are located in remote locations with little electric or thermal demand. Microturbines are ideal for farm projects because of their small modular size, although capital costs are a major issue. Most individual farms do not want to take the risk and commitment of investing in power generation equipment that may or may not pay off, especially if they don't currently utilize anaerobic digestion (most farms do not). Conceptually, it would make more sense to pool the digester gas from several farms together to produce utility electricity on a larger scale, but ownership, liability and transportation issues have prevented this model from being successful. Cornell University conducted a study “Single, Paired, and Aggregated Anaerobic Digester

\footnotetext{
142 Ibid.

143 Ibid.

${ }^{144}$ United States Department of Energy, Pacific Clean Energy Application Center, Project Profile: Sierra Nevada Brewery, updated 2011.
} 
Options for Four Dairy Farms in Perry, New York” and found that the economics tend to work best for single-farm projects, mainly due to the required transport of gas between farms. ${ }^{145}$

In a recent dairy farm ADG project, Pearl Valley Cheese, a family-owned business in Central Ohio, installed a $65 \mathrm{~kW}$ Capstone microturbine. The anaerobic digester gas was previously used to fuel a steam boiler for process heat, but falling natural gas prices and rising electricity prices influenced the company's decision to adopt CHP. A high-pressure moisture removal system was necessary, but other modifications to accommodate the microturbine system were minimal. The system was custom-designed and installed by GEM Energy of Walbridge, Ohio. ${ }^{146}$

Third party ownership is another option for farms that lack the capital to make an investment.

Environmental Power Corporation's subsidiary, Microgy Cogeneration Systems, developed a business model for installing power generation equipment at farms with anaerobic digesters and selling the electricity to utilities. They started a number of farm-based ADG projects in the early-to-mid 2000's, providing the funding and upkeep of the power generation equipment (usually microturbines) in exchange for rights to the electricity produced. However, the company appears to be no longer in business, which indicates that there could have been some problems with this business model.

Overall, anaerobic digester gas continues to be one of the most promising opportunity fuels for CHP applications, especially at wastewater treatment facilities. The market potential for ADG will be thoroughly evaluated in the following section of this report.

\subsection{COALBED METHANE}

Coalbed methane is a high quality fuel source, very similar to natural gas. The technical potential for CHP projects is not very high, however, and coalmines generally have little to no thermal demand. Facilities and equipment manufacturers were contacted to examine these problems, and to see if there were any other issues with the fuel.

Most of the time, the high quality methane collected from mine drainage holes is cleaned and injected into a natural gas pipeline. Many coalmines have a pipeline running through their site, and pipeline sales are a much more attractive financial option to on-site power production. When CBM has been utilized on-site, it is always exclusively for electricity. Some electricity-producing facilities were contacted, and there are no apparent problems with the fuel. It is easily collected through drainage holes, and only a minor cleaning and scrubbing is required before it is ready to use. Gas turbines and reciprocating engines have traditionally been used as prime movers in CBM projects, and they perform just as well as they do with natural gas. Recently microturbines have become popular for CBM, with Capstone reporting about 60 microturbine projects currently underway. Most coalmines have high electric demands, so they utilize all of the electricity that they produce. Although waste heat is sometimes recirculated or otherwise distributed, the thermal demand at coalmines is generally too low to warrant combined heat and power.

However, there is still some hope for coalbed methane-fired CHP. If a nearby facility is willing to be a host for the thermal load, then a combined heat and power project could be implemented. The generator

\footnotetext{
${ }^{145}$ Bothi, Kimberly L. and Aldrich, Brian S. Single, Paired, and Aggregated Anaerobic Digester Options for Four Dairy Farms in Perry, New York. Cornell University Dept. of Biological and Environmental Engineering. May 2005.

${ }^{146}$ Hardesty, Linda, Ohio Cheese Maker Uses Dairy Waste to Generate Electricity, Energy Manager Today (Online), April 12, 2013.
} 
could either be located on-site, or the gas could be pipelined to the facility. In either case, the facility would have to be located fairly close to the coalmine. For most coalmines, however, there are no nearby facilities to be found and pipeline sales are an easy and economical option. While many coalmines have chosen to utilize their methane on-site instead of pipeline injection, they are all strictly producing electricity. No known CHP projects have been documented, and it appears that none are currently being planned.

While the thermal demand at or near most coalmines is much too small to warrant CHP projects, coalbed methane makes an excellent fuel choice where power can be utilized, and there is still a fairly large market among the United States coalmines. Although many prefer pipeline sales, CHP projects can be even more profitable, and most coalmines could benefit from on-site power production. The coalmines with the best potential for CHP projects are those without nearby access to natural gas pipelines, but with close grid access so that some of the electricity can be sold. However, the number of underground coalmines is limited, thermal demand is minimal, and many of the best potential candidates are already benefiting from pipeline sales. Even considering all of the potential sources for coalbed methane, there is less than $7 \mathrm{GW}$ of technical potential in the country. There simply aren't enough coal mines with resources, unless unused coalbeds were drilled for the gas - and even then, it would likely just be used for natural gas sales. Due to coalbed methane's low technical potential and limited CHP capabilities, it will not be considered for further evaluation in this report.

\subsection{LANDFILL GAS}

Landfill gas has been used as a fuel for many CHP projects, and there are many facilities that could potentially benefit from its use. However, most LFG energy projects involve either companies purchasing LFG from landfills and generating electricity for utility sales, taking advantage of state and federal incentives for such projects, or cleaning up the gas and selling it via pipeline. Companies like INGENCO, Allied Waste, Granger Electric/Energy, and Waste Management Inc. have turned this into a fairly successful business practice, selling electricity at 4-6 cents per kWh. Waste heat is generally not utilized in these applications, but there are opportunities for industrial facilities near landfills to utilize the gas in CHP configurations. The EPA's Landfill Methane Outreach Program (LMOP) can provide assistance in project planning, while federal and state government incentives can help with financing. This could make landfill gas an attractive option for industrial facilities seeking a low-cost source of heat and power.

Landfill gas project operators find that with sufficient filtering and cleaning, there are no substantial issues with using LFG as a fuel, other than its sometimes-unpleasant odor and the occasional buildup of silicon dioxide. Most generators that are being used in LFG projects have either been custom-designed for landfill gas, or can handle the gas without any serious issues, provided it has been properly treated. Reciprocating engines are most commonly used with LFG due to their flexibility, high electric efficiency, and low capital cost, but microturbines

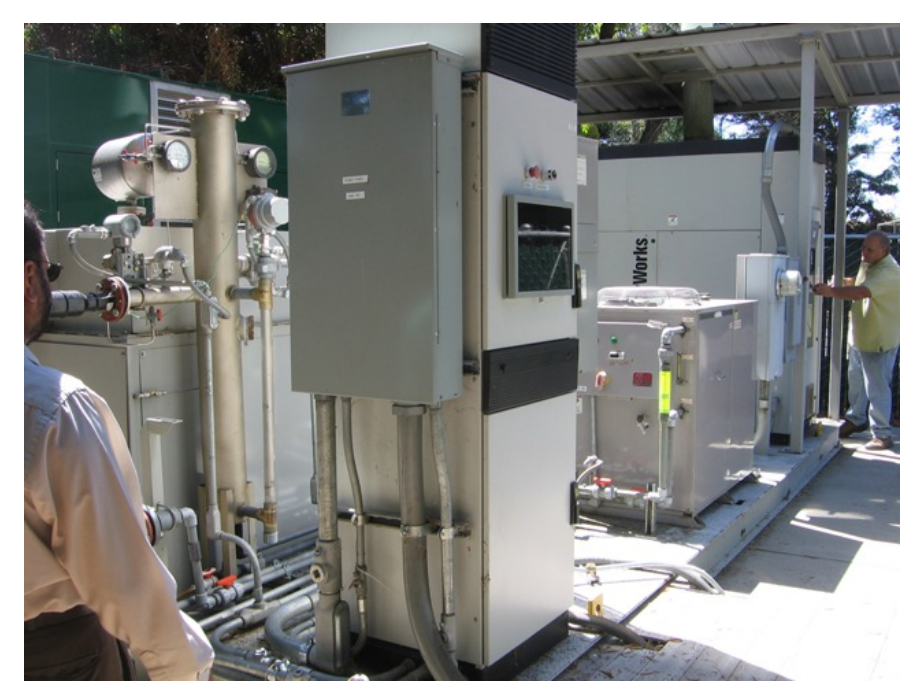

Figure 27. Landfill Gas Microturbines at Shoreline Landfill, California (Source: http://www.calrecycle.ca.gov) 
have found some success with smaller LFG installations. Larger combustion turbines have also been employed for LFG utilization. Silicon dioxide deposits can form when siloxanes are present, but this is a problem that is more prevalent in ADG installations. Special carbon filters should be used whenever high amounts of siloxane are found in the LFG project's waste stream. In most cases, an iron filter is also required to prevent hydrogen sulfide contamination, and desiccant formation can also be a concern.

At large landfills, much of the gas collection equipment is already in place since they are required to either flare or utilize their waste gas. Smaller landfills that do not fall under state or federal guidelines may not have the correct gas collection equipment in place, which can add significantly to the capital cost. However, if there is a nearby facility or third party willing to participate in the project, only a gas collection system, drying/cleaning equipment, piping, and a genset need to be installed. In reality, finding nearby facilities that are ready and willing to undertake a LFG CHP project is often the most difficult task.

The most publicized landfill gas projects to date have been for utilities that build a facility utilizing landfill gas for central station power. Since the landfill gas is being used to power homes and commercial buildings, and because it is good publicity for the utility, these are the projects for which the most information is available. There have been numerous projects of this type - one that is particularly notable is Salt River Project's Tri-Cities Landfill, which pipes gas from three local landfills together into one central plant, producing power for the utility.

Some schools located close to landfills have successfully utilized the gas for heat and power, saving their school districts thousands of dollars in electricity and natural gas purchases. Pattonsville High School in Maryland Heights Missouri was the first to utilize LFG in 1997, but the gas is only used for heat. Several other schools began using landfill gas for heat, but the first one to utilize LFG for both heat and power was Antioch Community High School in Antioch, Illinois. This school uses twelve $30 \mathrm{~kW}$ Capstone microturbines, all operating on LFG, to provide heat and power for the building. Both of these schools have benefited from utilizing LFG and have reported no serious problems to date.

In rare cases, the landfill itself may be able to finance the project, installing a genset on-site and selling excess electricity to a local utility. The Sauk County Landfill in Wisconsin is an example of this practice - eight $30 \mathrm{~kW}$ Capstone microturbines were installed in 2003, and the electricity produced is sold to Alliant Energy (Wisconsin Power \& Light). Since landfills are typically located in remote locations, however, grid interconnection can become an issue with this scenario.

With LFG projects, sometimes additional gas wells need to be drilled at the landfill, as was the case with the Avery County Landfill in Newland, North Carolina. The LFG flow rate at this landfill was too low, so more gas wells were drilled, and the extra costs nearly crippled the project. Most of the time, however, the flow rate is adequate and extra gas wells are not necessary. As long as all of the equipment is designed and installed correctly, and the genset properly maintained, there are very few problems with landfill gas as a fuel.

The traditional rule of thumb has been that industrial facilities should be located within 5 miles of a landfill in order to economically utilize the gas, but some new installations are questioning this notion. In Virginia, Honeywell International Inc.’s Hopewell manufacturing plant completed a 23-mile pipeline from a large landfill in Waverly, owned by Atlantic Waste Disposal Inc. The Hopewell plant uses natural gas for various plant operations, as well as a raw material to manufacture a key ingredient in nylon. 
According to plant manager Rick Higbie, "We are probably the largest consumer of natural gas on the East Coast and one of the largest in the United States". ${ }^{147}$

As natural gas prices increased around the turn of the century, the Hopewell plant began looking for ways to cut their dependency on the fuel, and an agreement with Atlantic Waste Disposal was reached. An 18inch polyethylene pipe was constructed underground, spanning 23 miles. A third party, DTE Energy, operates the gas collection system and pipeline. When LFG reaches the Hopewell plant, it is blended with natural gas and used for steam generation, power production and other industrial processes. Landfill gas now displaces about 15 percent of the plant's natural gas fuel requirements, and eventually it will displace up to 50 percent of the plant's fuel needs as the landfill grows in capacity. ${ }^{148}$

Another long pipeline of nearly 10 miles was installed at the BMW manufacturing plant in Spartanburg, South Carolina in 2003. The Palmetto Landfill pipes their gas to the BMW plant, where it is used to fuel two combustion turbines that produce a combined $11 \mathrm{MW}$ of electricity. Heat is recovered from the turbines and used in the facility as process steam. The system produces 30 percent of the plant's electrical needs and 60 percent of its thermal needs. A 20-year purchase agreement was made with the Palmetto Landfill before the 9.5-mile pipeline was constructed. To protect their investment, BMW installed gas treatment equipment to remove siloxanes from the landfill gas before it is sent along the pipeline. $^{149}$

At the Calabasas Landfill in Agoura, California (Los Angeles County), a set of three Mercury 50 Turbines from Solar recently began operation. In 2004, the Los Angeles County Sanitation District approached Solar Turbines to inquire about LFG electricity production using their low-emissions Mercury $504.8 \mathrm{MW}$ gas turbines. Solar Turbines made some modifications to the design of the turbine to accommodate the medium-Btu biogas, and completed a 5-year development program. In June 2010, three Mercury 50 gas turbines began operating at the Calabasas landfill, selling most of the electricity to the local power grid. The turbines have been operating successfully, and several more Mercury 50 biogas turbine installations are currently under development. ${ }^{150}$ These new low-emission combustion turbine designs for medium-Btu biogas could pave the way for large industrial LFG utilization projects in areas with strict emission standards, such as California and the Northeastern states.

The main issue with landfill gas is its location-limited potential market. A landfill, a project developer and a third party or utility must agree on a contract that is mutually beneficial, and sometimes it is just not possible. Of the thousands of landfills across the U.S., around 400 are currently utilizing their gas for electricity, and the EPA has labeled nearly 1,800 more landfills as candidate or potential projects. ${ }^{151}$ The vast majority of existing LFG projects, however, are direct electricity sales, not CHP. Still, there could be a strong market for industrial landfill gas CHP with the remaining landfills, especially larger ones with nearby facilities that could support multi-megawatt installations. With the prospect of a low-cost fuel source, and thousands of potential projects, landfill gas is one of the most promising opportunity fuels, and it will be evaluated in the following section.

\footnotetext{
${ }^{147}$ Blackwell, John Reid. “Honeywell Finds a Solution to its Gas Needs”. Richmond Times-Dispatch. April 24, 2006. 


\subsection{TIRE-DERIVED FUEL}

Tire-derived fuel has been available for quite some time, but has not yet made an impact on the CHP market. The fuel is primarily used as a supplement to coal in cofiring applications. Its heating value is often higher than coal, and unprocessed TDF can be purchased for a much cheaper price, so cofiring is advantageous to most facility operators. While highly processed TDF can be burned exclusively in coalfired boilers with no necessary modifications, maintenance costs will increase, and processed TDF can be more expensive than coal. This is especially true when TDF must be transported over large distances, and a lack of TDF processing centers makes this highly probable for most potential locations. For this reason, lower-grade TDF is usually purchased for a relatively inexpensive price and cofired at 10-20 percent, with only a slight possible increase in maintenance costs for the unit.

TDF applications have been found in cement kilns, paper mills, and other industrial facilities, but it is typically either burned for heat, or as a supplementary boiler fuel. Scrap tires are chosen by cement mills and other industrial facilities because of their low price and high Btu content. The facilities burn whole tires at high temperatures to melt the embedded metal wires and extract all of the available thermal energy. Although this produces a considerable amount of emissions, controls can be put in place and these facilities often have lower emission limits than newer plants. Other facilities, such as paper mills, purchase tire-derived fuel as a supplementary boiler fuel, but rarely use it for a primary fuel source. Most often it is blended with wood fuels that are produced on-site (or coal) and used in fluidized bed or stoker boilers for industrial steam generation. While tire-derived fuel has found a niche in these two types of facilities, there are significant resources of scrap tires in the United States that could potentially be used for combined heat and power applications.

There are only two known facilities in the United States designed to burn 100 percent tire-derived fuel for electricity. The Sterling Energy facility in Sterling, Connecticut (formerly the Exeter Energy facility, pictured in Figure 28) was completed in 1991. It burned TDF in two inclined reciprocating grate boilers specifically designed for the fuel. The boilers reach temperatures of over 3,000 degrees Fahrenheit so that unprocessed tires can be used. The waste heat is used to preheat the feedwater for the boilers, and the steam is used to power a $30 \mathrm{MW}$ turbine. The boilers have had no major problems in over ten years of operation. It has recently been converted to burn biomass as well, to take advantage of renewable energy markets in the Northeast.

The other facility is a $20 \mathrm{MW}$ plant located in Ford Heights, Illinois that is capable of burning 17,000 lbs of tirederived fuel per hour. The plant was completed in 1996, but shortly after completion, Illinois modified its Retail Rate Act and repealed certain rate incentives, forcing the original owners into bankruptcy. In 1998, the plant was purchased by KTI, Inc.

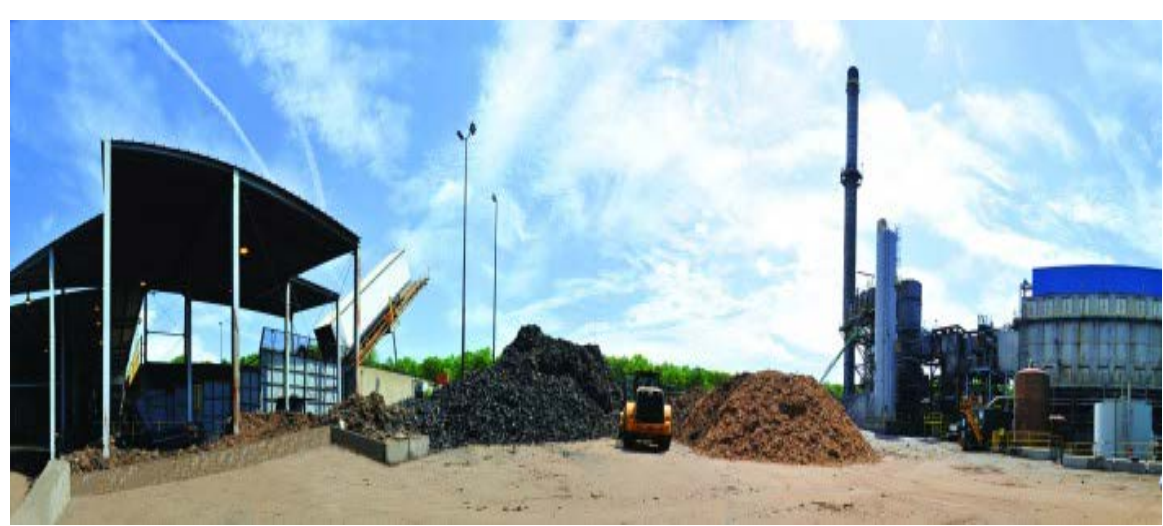

Figure 28. The Sterling Energy Facility designed to burn 100 percent tirederived fuel (Source: ReEnergy Holdings LLC) and Casella Waste Systems and put back into operation. The incentives were reinstated in 2002. Like the Sterling plant, the boiler was designed specifically for tire-derived fuel. 
Currently, the main markets for TDF are cement kilns, industrial facilities, and cofiring applications, where the fuel is primarily used for heat. Even in these applications, TDF utilization has run into some major barriers, many of which would also apply to potential CHP installations. A 2007 study on the use of TDF at industrial facilities in Virginia interviewed nine plants that had either burned tires as a fuel in industrial boilers or performed burning trials and chose not to continue. From these nine plants, six major problems were found. ${ }^{152}$

1) Seven plants felt they were hampered because the permitting process limited the amount of TDF they could burn, thereby limiting the economic advantage

2) Five plants found the permitting process to be excessively difficult, lengthy and costly

3) Four plants observed that wires from the tires clogged the grates in the boilers, creating hot spots that required temporary shutdowns and increased maintenance costs, and some plants reported difficulties mixing shredded tires with wood or other fuels

4) Four plants reported excessive zinc in the ash, which kept it from being sold in some cases

5) Two plants encountered high costs of additional pollution controls

6) Two plants faced strong negative public opinion

These issues are typical for TDF projects, although there are several ways to overcome them. A less difficult, lengthy, and costly permitting process, along with more thorough TDF processing, could help to alleviate most of these problems. Public opposition to local TDF projects, however, can be difficult to overcome.

Opposition to TDF projects is less likely to occur with cofiring applications, where only a small percentage of TDF is used in coal or biomass boilers. In order to use 100 percent TDF, the fuel must be heavily processed due to boiler performance and emissions issues. This processed TDF can sometimes cost more than coal, so there may be limited incentives for coal users to switch to 100 percent TDF. However, there is plenty of incentive for current coal-users to cofire TDF, since cheaper, low-grade TDF can be used, often with negligible effects on performance and emissions. TDF actually contains less sulfur and nitrogen than most coal, so less SOx and NOx emissions are produced in cofiring operations. Cofiring is a primary market for tire-derived fuel projects, but most coal-fired plants are large industrial or utility boilers. Additionally, the technical potential for TDF is not very high compared with most of the other opportunity fuels, and it is doubtful that even $1 \mathrm{GW}$ of electric capacity will ever be realized. It is unclear what lies in the future for tire-derived fuel, but as of this moment, it is not considered a prime contender for CHP applications.

\subsection{WOOD WASTE AND FOREST RESIDUES}

Wood waste fuels are often used for CHP projects in the wood and paper industries, but large amounts of wood waste and forest residues remain uncollected and under-utilized. Forest residues are generally more expensive to obtain than wood waste, but both fuels can be feasibly used for industrial CHP applications. Various facilities using wood waste fuels were contacted, and all that were contacted explained that they produce the waste themselves, meaning the only costs come from processing the fuel for combustion. While this is obviously an ideal option for those in the wood and paper industries, facilities that do not possess wood on-site can purchase other wood waste fuels from recycling yards and processing centers.

\footnotetext{
${ }^{152}$ Use of Tire-Derived Fuel In Virginia. Virginia State Advisory Board, Air Pollution. November 2007.
} 
In Vermont, where the forestry industry is large, the Joseph C. McNeil Generating Station contains a $50 \mathrm{MW}$ wood-fired power generation plant. The plant provides power for Vermont utilities using a mixture of harvested wood and wood waste for fuel, fired in boilers that power specially designed steam turbines. While most wood-fueled CHP applications utilize wood waste at industrial sites, this plant hauls in wood and wood waste from various local sources, including sawmills and urban wood waste. After a demonstration project using gasification completed in the late 1990s, the plant has been running for years without any major problems. When the wood-fired boiler is down for maintenance, the station switches to producing electricity with natural gas.

The Northumberland Cogeneration Facility in Pennsylvania provides a good example of a facility utilizing wood and wood waste fuels from outside sources to produce both power and heat. The facility obtains various types of wood fuel from a range of nearby sources, and uses the wood to produce power and heat in a boiler/steam turbine configuration. Chips and shredded wood from logging and recycling sources, tree debris from development land clearing, yard waste, sawmill residue, and other types of wood waste fuel are all combined and processed into wood chips. The chips are screened and sorted, metal is removed, and they are incorporated into the stack of wood fuel, using augers and belts to feed the combustion chamber. In the end, 16.2 MW of net electricity is produced and sold to Pennsylvania Power and Light, and expanded steam is sold to a nearby processing plant. ${ }^{153}$ This facility demonstrates how biomass fuels varying in origin, quality and consistency, can be flexibly combined in boilers to produce steam for industrial processes at a competitive price.

In New Jersey, the Rex Lumber Company provides an example of a lumber processor utilizing their wood waste for heat and power. The company produces over 44,000 cubic yards of wood waste annually previously the waste was trucked away to a landfill for disposal. A wood waste boiler system was recently installed to provide heat for the kiln-drying process the company uses. A $150 \mathrm{~kW}$ steam turbine was added to the system to lower plant electricity costs. Overall, the project has been a success and Rex Lumber Company has saved thousands of dollars in annual energy costs. ${ }^{154}$

Another example of CHP at a lumber company can be found in Josephine County, Oregon at the Rough and Ready Lumber mill. In February 2008, the mill began operation of a 1.5 MW CHP system using wood waste to generate heat and power. The heat is used to dry lumber on-site in 12 different kilns, while all power is sold to PacifiCorp, the local utility. Rough and Ready buys back the power that they need to run the plant at the wholesale rate, and they sell more than 10 million kWh of electricity to PacifiCorp each year. The project would not have been possible without government incentives for combined heat and power as well as biomass utilization. With tax credits and incentives, including a \$1.7 million grant from the Energy Trust of Oregon, the payback period is estimated at 4 years, but without the incentives, payback would likely have taken 15 years. ${ }^{155}$ Later in the economic analysis of this report, the 10 percent federal investment tax credit for CHP systems is considered for all potential wood waste CHP projects, but state incentives are not considered due to limited project funding and variable requirements.

For pulp and paper mills, as well as wood product manufacturers, it is common practice to utilize on-site biomass waste fuels in boilers and back pressure steam turbines. The utilization of wood waste for heat and power at these facilities comes as second nature to site operators, using boilers that have been designed to handle wood fuels. Some types of wood waste require more preparation and cleaning than others, but they all seem to perform well in stokers and fluidized bed boilers, despite having a lower

\footnotetext{
${ }^{153}$ Case Studies on Wood Biomass Use in the Northeastern United States, West Virginia University Division of Forestry, Appalachian Hardwood Center, no publication date listed.

${ }^{154}$ Telephone conversation with Rex Lumber Company manager, 2005.

${ }^{155}$ U.S. DOE Northwest Clean Energy Application Center. Rough and Ready-1.5 MW Wood-Fired Combined Heat and Power Plant. Project Profile.
} 
energy content and higher tar production byproduct than coal. Some plants may purchase additional forest residues and urban wood waste to provide more fuel for their boilers. In most cases, more electricity and/or steam are required on-site, necessitating additional fuel and electricity purchases. However, recently there have been some projects designed to draw from even more waste fuels and nearby biomass resources at paper mills in a large boiler/steam turbine configuration. Excess electricity is sold, while the mill utilizes all of the steam output from the extraction turbines. Recent CHP projects at paper mills in Port Angeles, Washington and Rothschild, Wisconsin have incorporated this practice.

In 2011, Nippon Paper Industries USA began construction on a 20 MW extraction/condensing steam turbine-generator with an inclined grate biomass boiler to provide electricity and steam to their paper mill in Port Angeles, Washington. Approximately 168,000 MWh will be generated each year, with excess electricity being sold into the California market, earning renewable energy credits from the California Renewable Portfolio Standard. The biomass CHP facility is scheduled to be completed by the end of 2013. Biomass will be hauled in from various sources within a 100 mile radius of the paper mill, consisting primarily of forest residues and lumber mill waste. The new CHP facility will lead to a reduction in nearly all emissions, including particulate matter, carbon monoxide, sulfur dioxide, and nitrogen oxide. The facility, an $\$ 85$ million investment, is expected to operate 355 days a year, with two planned annual outages for maintenance and cleaning. ${ }^{156}$

Domtar Corporation, owner of several pulp and paper mills throughout the country, has moved forward with two projects in which an agreement has been reached with a utility to support a large biomass boiler and steam turbine CHP installation. In 2009, Domtar and We Energies announced that construction would soon begin on a 50 MW CHP facility at Domtar's Rothschild, Wisconsin paper mill. The electricity, expected to average $37 \mathrm{MW}$ of net output, will be owned by We Energies. The electricity will contribute to the renewable energy portfolio, while steam will be sold to the Domtar mill. Wood, forest residues, wood waste, and sawdust will all be used to power the biomass boiler. Studies indicate that forests within a 75-mile radius of the mill can feasibly provide the power plant with residues for fuel. ${ }^{157}$ A similar 50 MW CHP installation also recently broke ground at Domtar's Marlboro, South Carolina paper mill, where they entered into a 15-year agreement with the Santee Cooper utility.

While these types of installations could become attractive for pulp and paper mills, it is unlikely that similar arrangements could be made with wood product manufacturers, who tend to produce large amounts of wood waste fuel, but do not require nearly as much steam at their plants. Wood product manufacturers generally utilize all of their wood waste for heat and power, but there could be potential for similar strategies to Nippon and Domtar involving excess electricity production and sales. The market potential for pulp and paper mills and wood product manufacturers to benefit from these practices will be explored in the next chapter of this report.

Although wood waste is an ideal fuel for those in the wood and paper processing industries, finding outside markets for the fuel could prove a challenge. For those without a supply of wood waste, wood fuels are only beneficial when their price is considerably less than coal. Wood-fired boilers tend to cost more than coal-fired boilers, and more maintenance is typically required. Additionally, coal is simply a superior fuel in terms of heat content and combustibility. Therefore, the only way wood fuels can be successful is if they cost significantly less than coal on a Btu-basis, or if state or federal government incentives were offered. Although some facilities may qualify for biomass tax credits, the price for wood wastes is usually about the same as coal, and harvested wood is typically more expensive. However,

\footnotetext{
${ }^{156}$ NPI USA Co-Generation Facility, Project Brochure, Nippon Paper Industries USA Co., LTD, February 2013.

157 "We Energies plans biomass plant at Domtar Rothschild Mill site”, Wisconsin Energy Corporation News, September 1, 2009, http://wecnews.wisconsinenergy.com/news/newsreel/pages/newsrelease_143
} 
there could be a market for both fuels in areas with concentrated biomass resources, and their potential will be further explored in the economic analysis.

Some industrial sites located in areas with plentiful biomass resources (such as the FERCO plant in Vermont and the Northumberland Cogeneration Facility in Pennsylvania) can collect wood and wood waste fuels from nearby resources with minimal transportation costs. However, the collection, processing and transportation costs associated with most harvested wood fuels are simply too high for most potential

projects. Urban wood waste fuels are less expensive than coal in most areas, and there is a large potential market for wood-fueled CHP at industrial sites. If a steady source of urban wood waste fuels can be obtained at a lower cost than coal, large-scale boiler/steam turbine systems could provide CHP to industrial sites and potentially some large commercial sites as well. In areas where wood and wood waste fuels are concentrated, they could become strong fuel options in the industrial CHP market.

\subsection{CHAPTER 5 SUMMARY}

Drawing from the information collected and presented in this section, the final screening has been completed, and only the most promising opportunity fuels were chosen for further evaluation.

Fuels Considered for Further Evaluation:

Anaerobic Digester Gas

Forest Residues

Landfill Gas

Wood Waste

Fuels Eliminated from Further Evaluation:

Coalbed Methane - Limited potential, coalmines not good candidates for CHP

Tire-Derived Fuel - Processed TDF can cost more than coal, limited market, limited potential

The next chapter of this project will discuss and present Resource Dynamics Corporation's DISPERSE model for opportunity fuels, along with the results that were obtained. This model will calculate the approximate cost to generate electricity with the different fuels, and compare it with electricity prices throughout the country. The model, based on fuel, equipment and maintenance costs, as well as local electricity rates, chooses the best locations for potential opportunity fuel projects and calculates the overall cost to generate electricity with various prime movers. Project economics are calculated over a 10 -year period, and the sites and sectors with the most promising economics and shortest payback periods are highlighted. 



\section{ANALYZING MARKET POTENTIAL WITH THE DISPERSE MODEL}

With the most promising opportunity fuels in focus, and potential resources identified, the next step was to analyze the CHP market potential for the fuels using Resource Dynamics Corporation's DISPERSE model (see Appendix B). Before the model could be implemented, some basic assumptions were made, and various forms of input data assembled for each fuel. Different strategies for applying the model were developed to work with the available data, with refined and improved strategies implemented for the 2013 update. While this analysis considers the Federal ITC for CHP systems, state and local incentives for CHP or renewable fuels were not assessed in this evaluation.

This section discusses the model inputs for the various fuels, as well as the underlying strategies and assumptions for model implementation. Then, the results are presented, giving the regional market potential for each of the chosen opportunity fuels. In the final chapter of this report, conclusions are drawn from the results and final recommendations are made.

\subsection{OVERALL RESULTS}

When the analysis of economically achievable market potential was completed, between 1.6 and $3.4 \mathrm{GW}$ was found among ADG, LFG, forest residue and urban wood waste CHP projects. The 2013 results for opportunity fuel CHP, using both high and low estimates are broken down in Figure 29.

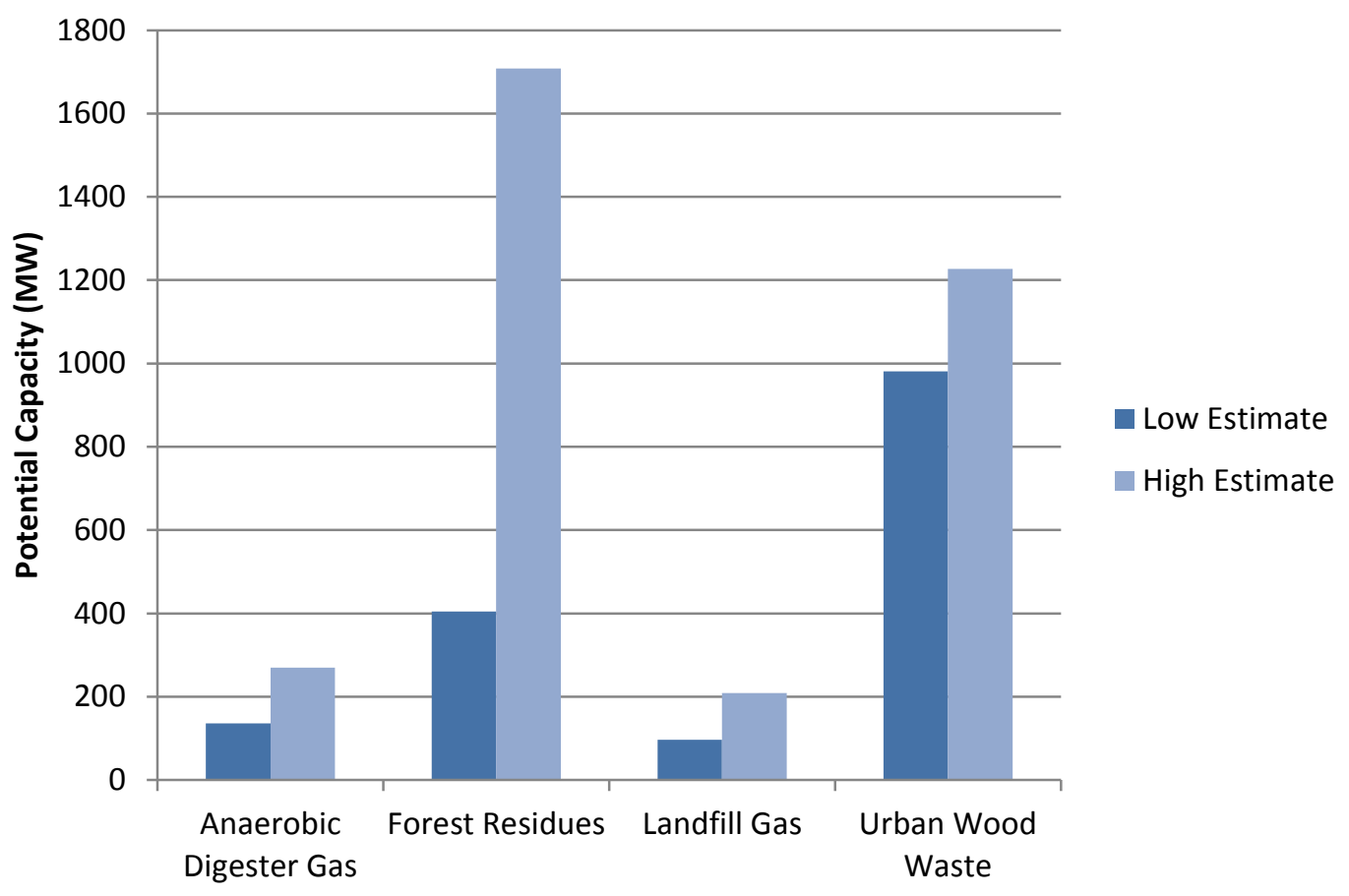

Figure 29. Overall Results by Fuel Type 
The largest opportunity lies with forest residues, which have significant potential capacity (up to $1.7 \mathrm{MW}$ ) for steam turbine CHP applications at industrial sites. However, the estimated potential depends heavily on the average transportation distances from forest residue source to CHP project, falling to $400 \mathrm{MW}$ when longer distances are assumed. The majority of forest residue potential comes from pulp and paper mills, which were treated as a special case in the analysis. Urban wood waste, a less-expensive source of woody biomass fuels, is capable of contributing between 980 and 1,190 MW of new CHP capacity, with less dependence on fuel transportation distances. The economic potential for ADG and LFG likely falls between 230 and $480 \mathrm{MW}$ combined, with many potential utilization projects, especially at municipal wastewater treatment plants with anaerobic digesters already installed.

These estimates do not include grid power export options, which could theoretically increase the size of the modeled CHP units. However, these opportunity fuel CHP systems are size-constrained by available fuel resources, and they are generally sized to their maximum potential, so grid export was not included as an option in the analysis.

The total estimated potential for opportunity fuels in 2013 ranges from 1.6 to $3.4 \mathrm{GW}$, significantly less than the $32 \mathrm{GW}$ that was estimated in the 2006 report. The primary reason for the large difference between 2013 and 2006 estimates is the exclusion of biomass gas in this analysis. In the 2006 report, advanced biomass gasifiers were considered to be an up-and-coming technology with strong potential for near-future commercialization. However, technological setbacks and the decrease in natural gas prices have slowed down the development of advanced gasification technologies, which now appear to be far from commercialization. Advanced gasifiers are a good candidate for focused research and development efforts, as low-cost, low-maintenance, high-efficiency gasifiers could open up the market to a large number of biomass-fueled CHP applications. In the 2006 report, gasified biomass accounted for 24 of the $32 \mathrm{GW}$ in the economic potential estimates, and solid biomass applications using urban wood waste accounted for $6 \mathrm{GW}$. The elimination of advanced gasification technologies along with increases in pricing estimates for biomass fuel and preparation equipment has caused the economic potential to fall for biomass resources.

The assumptions that produced the high and low estimates for each fuel are defined in Table 18.

Table 18. Assumptions for Conservative and Optimistic Estimates for Each Fuel

\begin{tabular}{|l|l|l|}
\hline Opportunity Fuel & Optimistic Assumptions & Conservative Assumptions \\
\hline $\begin{array}{l}\text { Anaerobic Digester Gas: wastewater } \\
\text { treatment plants with anaerobic } \\
\text { digesters installed }\end{array}$ & $\begin{array}{l}\text { Facilities with digesters but no } \\
\text { record of ADG utilization are } \\
\text { assumed to flare all ADG }\end{array}$ & $\begin{array}{l}\text { Facilities with digesters but no } \\
\text { record of ADG utilization are } \\
\text { assumed to use ADG for digester } \\
\text { heating (less thermal benefits) }\end{array}$ \\
\hline $\begin{array}{l}\text { Anaerobic Digester Gas: Farms and } \\
\text { WWTPs without anaerobic digesters }\end{array}$ & $\begin{array}{l}\text { Digester installation costs assumed } \\
\text { to be } \$ 1,000 / \mathrm{kW}\end{array}$ & $\begin{array}{l}\text { Digester installation costs assumed } \\
\text { to be \$3,000/kW }\end{array}$ \\
\hline Forest Residues & $\begin{array}{l}\text { Average transportation distance for } \\
\text { forest residues: } 10 \text { miles }\end{array}$ & $\begin{array}{l}\text { Average transportation distance: } 25 \\
\text { miles for pulp and paper mills, 50 } \\
\text { miles for other facilities }\end{array}$ \\
\hline Landfill Gas & $\begin{array}{l}\text { Fuel is piped 2 miles to nearby } \\
\text { industrial facility, no siloxane } \\
\text { removal required }\end{array}$ & $\begin{array}{l}\text { Fuel is piped 5 miles to nearby } \\
\text { industrial facility, and siloxane } \\
\text { removal is required }\end{array}$ \\
\hline Urban Wood Waste & $\begin{array}{l}\text { Average transportation distance for } \\
\text { urban wood waste: } 10 \text { miles }\end{array}$ & $\begin{array}{l}\text { Average transportation distance for } \\
\text { urban wood waste: 25 miles }\end{array}$ \\
\hline
\end{tabular}


Additional considerations, such as the effects of unscheduled maintenance (four weeks for biogas projects, two weeks for solid biomass boilers), federal tax credits, net metering, and siloxane treatment, have been incorporated into this 2013 analysis, some hindering and some helping project economics. The methodologies have also been refined to provide a more accurate estimate of the market potential by localizing solid biomass resources, eliminating some sites that already utilize opportunity fuels for CHP, and incorporating net metering for farm ADG operations. States with markets for renewable energy credits (RECs) were also considered, but the value of biomass RECs tends to be very small and economically insignificant compared to RECs from solar and wind power systems, so they were not included in the analysis. Overall, the result has been less economic potential estimated for opportunity fuels, and a more conservative assessment of the most promising applications.

In this update of the 2006 report, costs for pretreatment/processing equipment were re-established and found to be more expensive than previously estimated, and the economic conditions for power generation projects have generally become less favorable. The 2013 installed costs for engines and turbines, including all pretreatment equipment, are compared with 2006 estimates in Appendix B, along with an explanation for the DISPERSE model methodology. The primary changes from 2006 to 2013 are explained for each fuel.

- Anaerobic Digester Gas - Estimated pretreatment costs significantly increased, especially since siloxane removal was not considered to be necessary when the original analysis was conducted. Since then, the importance of siloxane removal has been shown as many sites required extensive and frequent cleaning to remove silicon dioxide deposits from engine surfaces. Additionally, about 100 municipal WWTPs that are already engaged in ADG CHP projects were identified ${ }^{158}$ and removed from the pool of potential sites. Large WWTPs that showed economic potential were also individually researched for more recent CHP project announcements, leading to the removal of several potential sites in New York and California.

- Forest Residues - Costs and state-level resources for forest residues were updated to reflect estimates from the DOE's 2011 Billion Ton Update ${ }^{159}$, and estimated transportation costs rose. County-level resources were compared to utility service territories in order to allocate forest residues properly, eliminating utilities that primarily serve urban areas. Sites that are known to utilize solid biomass fuels for CHP were also eliminated. ${ }^{160}$ Biomass prep yard expenses for fuel processing were updated. Back-pressure and extraction steam turbines were considered, leading to less potential for electric output and more for thermal output for most potential projects. Pulp and paper mills were evaluated as a special case with the potential to install CHP systems sized to their steam load with excess electricity using nearby forest residues as well as mill residues produced on-site. Finally, gasification was not considered in this update.

- Landfill Gas - The estimated costs for gas pretreatment and pipeline construction have increased since 2006. Instead of \$260,000 per mile, the EPA’s Landfill Methane Outreach Program (LMOP) now estimates $\$ 330,000$ per mile for most projects. ${ }^{161}$ Also, many more landfills that were previously the best candidates for LFG CHP have since engaged in energy projects. The latest LMOP database was queried for new LFG energy projects, and with the knowledge that California is aggressively pushing for new renewable generation, press releases for large California landfills were sought out to reveal recent project announcements that will take away

\footnotetext{
${ }^{158}$ ICF International, Combined Heat and Power Installation Database, 2013, http://www.eea-inc.com/chpdata/

${ }^{159}$ U.S. Billion-Ton Update: Biomass Supply for a Bioenergy and Bioproducts Industry, U.S Department of Energy, Oak Ridge National Laboratory, August 2011.

${ }^{160}$ ICF International, Combined Heat and Power Installation Database, 2013, http://www.eea-inc.com/chpdata/

${ }^{161}$ LFG Energy Project Development Handbook. US EPA Landfill Methane Outreach Program. 2010.
} 
potential LFG for CHP projects. This removed many landfills from the pool of potential sites. Finally, landfills now commonly charge third parties for access to their LFG, typically between $\$ 1$ and \$3 per MMBtu ${ }^{162}$, so an estimated cost of \$2 per MMBtu was incorporated into the analysis.

- Urban Wood Waste - Cost estimates for urban wood waste resources and transportation were slightly increased from the 2006 report, and biomass prep yard expenses were updated. State urban wood waste resources were allocated to utility service territories by assuming that the locations of resources line up with MSA populations. Facilities that already utilize solid biomass fuels for CHP were eliminated from the pool of potential sites in this update. ${ }^{163}$ Also, gasification systems were eliminated, and back-pressure and extraction steam turbines were evaluated, leading to less potential for electric output and more for thermal utilization. Finally, pulp and paper mills were evaluated as a special case with the potential to install CHP systems sized to their steam load with excess electric capacity using nearby urban wood waste resources as well as mill residues produced on-site.

Each fuel is examined and analyzed independently in this section, with DISPERSE model methodologies and low/high estimates for economic market potential, considering all of the possible sources for the fuels. Overall, markets with high population density and relatively high electricity prices show the most potential, as well as areas with high concentrations of biomass resources.

Most of the potential comes from reciprocating engine systems smaller than $10 \mathrm{MW}$ in size, but combustion turbines also show some potential for larger applications. While many potential projects require more than 5 years to break even, there are several opportunities for shorter payback periods with opportunity fuel CHP installations.

\subsection{ANAEROBIC DIGESTER GAS}

There are many opportunities for anaerobic digester gas projects in the United States, with four major fuel sources: municipal wastewater treatment plants, industrial wastewater treatment plants, dairy farms and hog farms. Each of these ADG sources is examined individually, with market analyses that determine the overall potential for power generation in the United States. In the end of the section, the results will be combined to give the total potential for ADG from all sources.

\subsubsection{Municipal Wastewater Treatment Plants}

For the purposes of this project, municipal wastewater treatment plants are divided into four categories:

(1) Plants that currently have an anaerobic digester and utilize their ADG for CHP;

(2) Plants that currently have an anaerobic digester and utilize their ADG for heat;

(3) Plants that have an anaerobic digester installed but do not currently utilize the gas; and

(4) Plants that do not currently have an anaerobic digester installed.

The first category, plants that already utilize their ADG for CHP, are not considered as candidates for new CHP projects. ${ }^{164}$ The second category, plants that have an anaerobic digester but are only known to

\footnotetext{
162 Ibid.

${ }^{163}$ ICF International, Combined Heat and Power Installation Database, 2013, http://www.eea-inc.com/chpdata/

${ }^{164}$ It is noted that some plants may be able to expand their CHP capacity due to additional biogas production, however these applications were not evaluated.
} 
utilize their ADG for heating requirements, could benefit from a CHP installation, although benefits from thermal energy savings would likely be limited. The third category, plants that have anaerobic digesters for wastewater treatment purposes, but are not known to utilize their digester gas, are considered the best candidates for ADG projects in terms of potential energy savings. The largest category of WWTPs, those that do not currently have anaerobic digesters, would have to construct and maintain the digester equipment, which adds significant costs. Still, many large WWTPs in this category could potentially benefit from ADG utilization, especially where electricity prices are high.

The 2008 EPA Clean Watershed Needs Survey ${ }^{165}$ was used to assemble a database of municipal WWTPs in the United States. The survey included information such as the average amount of wastewater that the plants process (in millions of gallons per day), whether or not anaerobic digestion is used, and if the digester gas is utilized. Additionally, the DOE database of CHP installations ${ }^{166}$ was used to eliminate sites that are already fully engaged in CHP projects. Announcements for new WWTP CHP projects using ADG were also sought out and used to eliminate potential sites, with a focus on California and New York. Both of these states have numerous large wastewater treatment plants in high-electricity-price areas, and they have both been aggressive in supporting new renewable fuel power generation.

Although the organic loading content of wastewater can vary from location to location, in general, for every 1 million gallons of daily processed wastewater (1 MGD), about 12,000 cubic feet per day of ADG is produced. With a heat content of $600 \mathrm{Btu} / \mathrm{ft}^{3}$ and an electric efficiency of 30 percent (HHV), about 27 $\mathrm{kW}$ of electricity could be produced at a 1 MGD plant - enough to support a small microturbine or engine project. If the plant were any smaller, it is likely that CHP would not be feasible. Therefore, this analysis uses a cutoff point of 1 million gallons of processed wastewater per day in order for WWTPs to be considered eligible for CHP projects.

Another important issue to analyze is the thermal and electric power required by the treatment plant. To keep the wastewater sludge heated at an optimal temperature (about $95^{\circ} \mathrm{F}$ ), an anaerobic digester typically requires about half of the thermal energy it is capable of producing. The amount of heat required depends on outside ambient temperatures - cold climate locations require more heat. ${ }^{167}$ With CHP systems, waste heat from the prime mover can be utilized to keep the digester tank heated. Many plants with anaerobic digesters already utilize some of their ADG for digester heating, although there are other potential on-site uses for thermal energy such as space heating. Plants using other methods for wastewater treatment (such as aerobic digestion) require power to operate aeration fans or blowers, so switching to an anaerobic digester would decrease their overall electric load. For all treatment plants, the DISPERSE model calculates the electricity and heat that the genset is capable of producing, and uses this to replace utilitypurchased power. However, the thermal requirements for a wastewater treatment plant are seasonal, and for most U.S. locations, about one third of the heat recovered throughout the year would not be useable due to lack of demand. ${ }^{168}$ All of these factors were considered when estimating the potential for ADGfueled CHP at municipal WWTPs.

\footnotetext{
${ }^{165}$ United States Environmental Protection Agency, 2008 Clean Watersheds Needs Survey, January 2011. http://water.epa.gov/scitech/datait/databases/cwns/2008reportdata.cfm

${ }^{166}$ ICF International, Combined Heat and Power Installation Database, 2013, http://www.eea-inc.com/chpdata/

${ }^{167}$ U.S. Environmental Protection Agency, Combined Heat and Power Partnership, Opportunities for Combined Heat and Power at Wastewater Treatment Facilities: Market Analysis and Lessons from the Field, October 2011. 168 Ibid.
} 


\subsubsection{Price and Performance Parameters}

In order to formulate the inputs for ADG in the DISPERSE model, some general assumptions were made. The cost of a digester can vary greatly, and depends on a number of different factors. Generally, anaerobic digesters cost between $\$ 1,000 / \mathrm{kW}$ and $\$ 3,000 / \mathrm{kW}$ to install, which was confirmed by analyzing several ADG case studies at both WWTPs and farms. This assumes that all of the ADG is utilized by a prime mover with an electric efficiency of around 30 percent. If the CHP system is sized smaller than this, or is less efficient, the total cost for the digester remains the same, but the cost per $\mathrm{kW}$ will increase accordingly.

Because ADG has a lower heat content than natural gas, electric efficiencies are slightly downgraded in comparison. In addition, the costs for equipment and maintenance are increased slightly, as quantified in Chapter 3. Finally, pretreatment equipment is required, including siloxane removal for many installations. Including siloxane removal, the fuel treatment equipment can cost up to $\$ 2,500 / \mathrm{kW}$ for small projects, or below $\$ 500 / \mathrm{kW}$ for large ones (pretreatment costs are also discussed in Chapter 3). Otherwise, the price and performance parameters are generally in line with prime movers fueled by natural gas.

A federal investment tax credit for ten percent of project costs for CHP systems was incorporated into the DISPERSE economics. This credit applies to the entire CHP system, including pretreatment equipment, when the total CHP efficiency is 60 percent or higher.

\subsubsection{Load Profiles}

Although the EPA Clean Watersheds Needs database ${ }^{169}$ provides daily wastewater throughput data, plant specific energy requirements for the treatment operations are not included. WWTPs operate around the clock, and wastewater is constantly being treated. By assuming a plant's electricity needs are directly related to its daily wastewater throughput, a constant multiplier (kWh/MGD) was derived based on research into several in-depth WWTP reports, mainly a statewide assessment of Wisconsin's potential for ADG-fueled CHP. ${ }^{170}$ Since wastewater is always being introduced to the plant's system, and operating the wastewater treatment system is the plant's main electric load, a nearly constant load profile is assumed ( 95-100\% capacity during the week, and $~ 80 \%$ capacity on weekends/holidays).

As stated before, 1 MGD of wastewater can generate enough ADG to produce approximately $27 \mathrm{~kW}$ of electricity, assuming a prime mover efficiency of 30\% (HHV). Most plants with anaerobic digesters produce enough gas to power a considerable portion of the plant. Even with the range of considered genset technologies and their efficiencies, none of the systems produce any appreciable excess electricity beyond the treatment plants' strong demands while just using site-produced ADG. Therefore, it is assumed that all electricity produced by the digester gas gensets will be used by the plant.

In addition, plants already utilizing their ADG for digester tank heating will not realize the full thermal benefits of CHP utilization. WWTPs currently utilizing ADG for heat are primarily using it to heat the digester tank, which can require a significant amount of energy, especially in colder climates. Resource Dynamics Corporation performed an analysis for the U.S. EPA Combined Heat and Power Partnership to provide a climate-based relationship for digester tank heating requirements as they relate to different U.S.

\footnotetext{
${ }^{169}$ United States Environmental Protection Agency, 2008 Clean Watersheds Needs Survey, January 2011. http://water.epa.gov/scitech/datait/databases/cwns/2008reportdata.cfm

${ }^{170}$ Vik, Thomas E. Anaerobic Digester Methane to Energy - A Wisconsin Statewide Assessment. Prepared for Focus on Energy, January 2003.
} 
climate zones. The analysis revealed that the heat load for digester tanks can require nearly all of the heat from ADG-fueled CHP units (and sometimes more in the coldest climates). ${ }^{171}$ In this updated report, the climate-based digester tank heating requirements are used to provide an accurate measure of economic potential for plants that may be already using ADG directly (not CHP) for this purpose.

\subsubsection{Results: Plants With Anaerobic Digesters}

The 2008 EPA Clean Watersheds Needs Survey (CWNS) database ${ }^{172}$ was queried for plants that contain anaerobic digesters, and cross-referenced for plants that are already utilizing their digester gas in some way. Additionally, the DOE's CHP installation database ${ }^{173}$ and recent press releases were consulted to find the WWTPs currently engaged in ADG-fueled CHP projects. These sites were eliminated from consideration. Other plants that are listed in the CWNS as utilizing their ADG were included in the analysis, assuming diminished thermal utilization potential for recovered waste heat (using the climatebased model mentioned in the previous section). This reduces potential savings from avoided natural gas purchases compared to facilities who are not utilizing their ADG.

Overall, there are 1,425 treatment plants in the CWNS database that treat over 1 MGD, possess anaerobic digesters, and have not adopted a CHP project. According to the CWNS data, 198 of these plants are utilizing their ADG in some other way, although it should be noted that survey responses are voluntary and it is likely that many more plants with digesters are utilizing their gas for digester heating, and possibly other purposes. All of the wastewater treatment plants with anaerobic digesters were evaluated using the DISPERSE model. This was done by matching up location information with specific utilities, estimating the savings ADG CHP utilization could produce against utility tariffs, and calculating the payback periods and net present values of the CHP investments.

Of the 198 municipal wastewater treatment plants that are known to utilize their digester gas (but not currently for CHP), 87 returned a positive net present value on their potential CHP investment. This is assuming that these sites only utilize their ADG for digester tank heating. The total estimated potential CHP capacity for these plants is $40.3 \mathrm{MW}$, primarily with small engines at plants processing between 1 and 10 MGD (a common size range for plants using anaerobic digestion). For the other 1,227 municipal facilities currently using anaerobic digestion but with no reported ADG utilization, the estimated potential depends on whether or not current ADG utilization is assumed.

If all of the remaining plants with anaerobic digesters currently utilize their ADG for digester tank heating, despite not indicating so in the CWNS survey, 319 plants show a total potential of 93.6 MW. Reciprocating engines are the most economically beneficial prime mover for plants processing less than 200 million gallons per day, according to the DISPERSE model results. For sites processing less than 7-8 million gallons per day (supporting CHP systems $200 \mathrm{~kW}$ or smaller), microturbines have similar economics and are extremely competitive with engines. The prime mover choice for these smaller sites depends on factors like electric efficiency, emissions, and required maintenance of the systems (engines have higher efficiencies, while microturbines require slightly less maintenance and generate fewer emissions with off-the-shelf units). For plants processing more than 200 million gallons per day, combustion turbines $5 \mathrm{MW}$ or larger in size generally provide the most attractive economic benefit.

\footnotetext{
${ }^{171}$ U.S. Environmental Protection Agency, Combined Heat and Power Partnership, Opportunities for Combined Heat and Power at Wastewater Treatment Facilities: Market Analysis and Lessons from the Field, October 2011. ${ }^{172}$ United States Environmental Protection Agency, 2008 Clean Watersheds Needs Survey, January 2011. http://water.epa.gov/scitech/datait/databases/cwns/2008reportdata.cfm

${ }^{173}$ ICF International, Combined Heat and Power Installation Database, 2013, http://www.eea-inc.com/chpdata/
} 
The market potential for these remaining plants is substantially improved if it is assumed that the digester gas is not being used, as is suggested in the CWNS survey. For these sites, the full thermal benefits of CHP can be realized. Using this assumption, 622 plants show a total potential of $136.5 \mathrm{MW}$ (many smaller plants become economically viable with both thermal and electric CHP benefits). The actual economic potential for this subset of WWTPs is believed to be somewhere between these two estimates, but the optimistic estimate of 136.5 MW is used when estimating the market potential.

Overall, there are between 409 and 713 municipal WWTPs with anaerobic digesters that could potentially benefit from CHP. The total potential ranges from $134 \mathrm{MW}$ to $177 \mathrm{MW}$, depending on current ADG utilization practices, with payback periods ranging from 2 to 7 years. The Mid Atlantic and East North Central regions, both highly populated areas with relatively high electricity prices, show the most potential, followed by the Pacific region. Engines dominate this market due to their lower cost and higher efficiency compared to microturbines and small combustion turbines, but two large (>300 MGD) plants showed potential for combustion turbines in the 5-15 MW size range. Also, payback periods for small $(<200 \mathrm{~kW})$ microturbine installations are typically within a half year of small engines, so in many cases either technology can be economically utilized.

The states with the most potential for CHP at municipal wastewater treatment plants are states with large population centers, because they include the largest treatment plants capable of supporting the largest CHP systems. High electricity prices are another major factor in project economics, but plants that are capable of supporting multi-megawatt installations can still be economical with lower electricity prices. The most promising opportunities lie in New York, Illinois, Michigan, Ohio and California. The top states are broken down in Figure 30, giving the potential capacity for both the conservative (low) and optimistic (high) estimates.

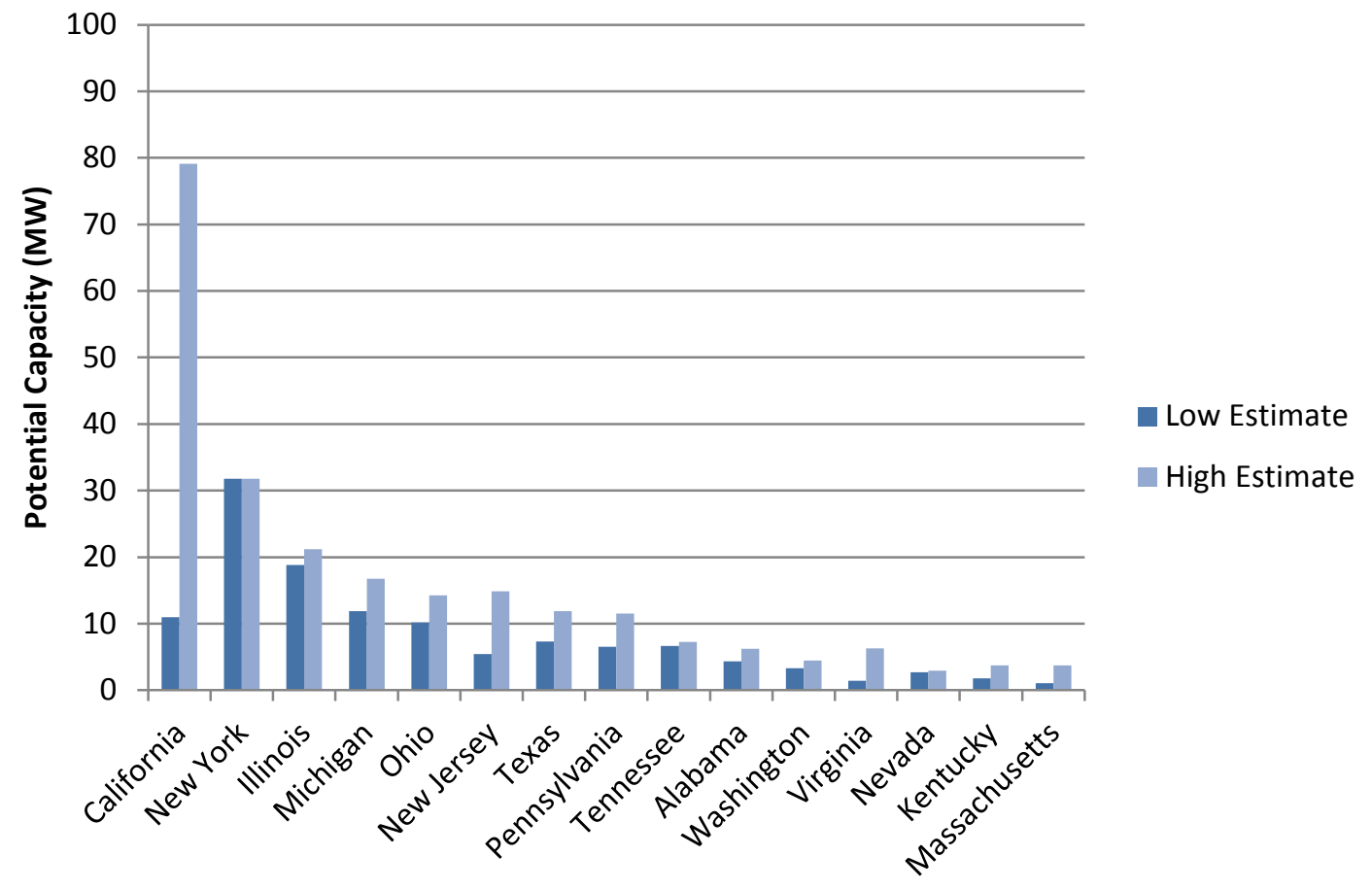

Figure 30. Top States for ADG-Fueled CHP at Municipal Wastewater Treatment Plants with Anaerobic Digesters 
In Figure 31, the potential for municipal wastewater treatment plants with digesters is broken down by payback period range, and in Figure 32, it is broken down by size range and technology, assuming that most treatment plants do not utilize their ADG for heating (optimistic estimate, yielding $177 \mathrm{MW}$ of total potential).

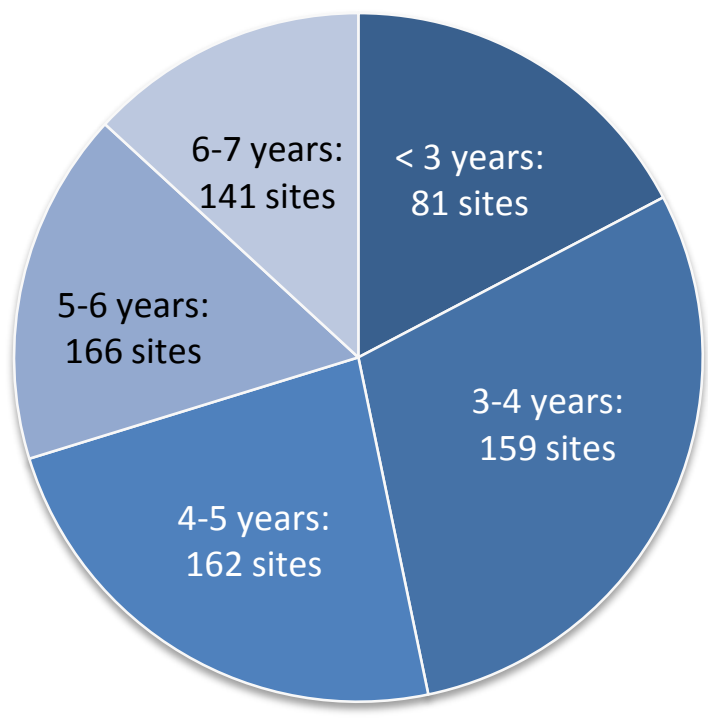

Figure 31. Payback Period Ranges for ADG CHP at Municipal WWTPs with Anaerobic Digesters (177 MW Total, Optimistic Estimate)

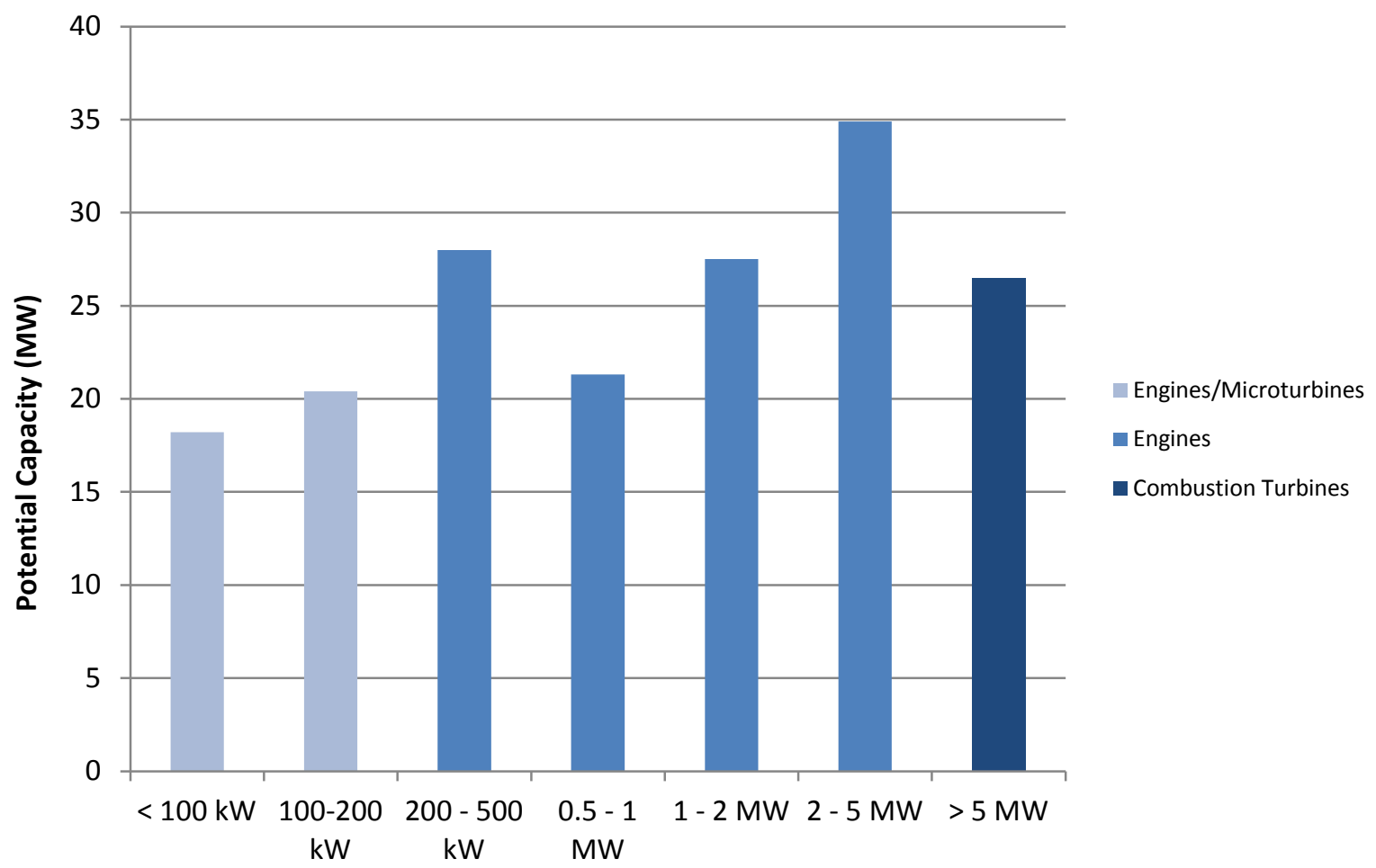

Figure 32. Potential for Municipal WWTPs with Digesters by Size Range and Tech 


\subsubsection{Results: Plants Without Anaerobic Digesters}

When the EPA Clean Water Needs Survey database was queried for WWTPs processing over 1 MGD using treatment methods other than anaerobic digestion, 1,963 facilities were found. ${ }^{174}$ Because of the additional capital cost of a digester (which equates to about $\$ 1,000-\$ 3,000$ per $\mathrm{kW}$ ), the payback periods for these plants are significantly longer than for plants that already possess anaerobic digesters. With a $\$ 1,000 / \mathrm{kW}$ digester cost, 130 treatment plants were able to produce a positive net present value with their investment, and the total potential capacity is $15.9 \mathrm{MW}$. Two treatment plants in New Jersey were able to achieve a payback period of less than four years, and some plants were able to achieve a payback period in the range of 4-5 years, but the vast majority of plants required more than five years to break even on their investment. While some of the larger WWTPs not using anaerobic digestion showed potential, the majority of sites are relatively small plants in high electricity price states like California, Connecticut and New Jersey. Engines were the favored technology for all potential sites except for a large 278 MGD New Jersey treatment plant that was projected to economically support a $5 \mathrm{MW}$ combustion turbine.

Microturbines also showed competitive economics for systems $200 \mathrm{~kW}$ or smaller, with payback periods only about a half-year longer than similarly-sized engines.

Anaerobic digesters can be costly investments, sometimes adding more than $\$ 3,000$ per $\mathrm{kW}$ to the CHP system investment. For a high-cost scenario, the digester cost was increased to $\$ 3,000$ per $\mathrm{kW}$, while other installation and maintenance costs remained the same. Under this scenario, no potential was found among WWTPs without anaerobic digesters.

In general, municipal WWTPs using other treatment methods need to be able to install a digester for the equivalent of around \$1,000 per $\mathrm{kW}$ in order for ADG CHP economics to work. However, treatment plants may look to install a digester for other reasons, such as odor reduction or eliminating land application of solids. In some cases, plant operators may be willing to adopt digesters given the benefits that ADG-fueled CHP can provide. Also, the avoided cost of maintaining or overhauling old treatment equipment can effectively reduce the overall cost of a new anaerobic digestion system.

If anaerobic digesters can be installed for an equivalent of about $\$ 1,000$ per $\mathrm{kW}$ of electricity (assuming they are paired with a prime mover that can utilize all of the digester gas to provide heat and power for the plant), there are several WWTPs in New Jersey, New Hampshire, and possibly Hawaii that could break even on their investment in less than five years. Other sites in states like Connecticut, California, and even Kentucky show some potential, but may require a longer payback period. Again, the total potential for these sites is estimated at 15.9 MW. It should be noted that the estimated costs of installing new anaerobic digester systems $(\$ 1,000-\$ 3,000 / \mathrm{kW})$ are largely based on recent agricultural ADG projects, while installations at wastewater treatment plants could require more redesigning and engineering, potentially increasing the cost. Overall, unless a treatment plant is already considering switching to anaerobic digestion, the focus for new CHP development should be on WWTPs that already contain anaerobic digesters.

\subsubsection{Industrial Wastewater Treatment Plants}

Wastewater treatment plants are also located at some industrial plants that produce wastewater as a byproduct of their manufacturing processes. While some industries may produce wastewater with a low volatile/organic content, many industries such as food \& beverage, paper and chemical processing consistently produce organic wastewater with a similar concentration of potential biologically digestible

\footnotetext{
${ }^{174}$ United States Environmental Protection Agency, 2008 Clean Watersheds Needs Survey, January 2011. http://water.epa.gov/scitech/datait/databases/cwns/2008reportdata.cfm
} 
compounds comparable to municipal treatment plants. Data on industrial treatment plants was not included in the EPA Clean Water Needs Survey, but it can be found in the EPA Envirofacts database of water discharge permits. Flow rate data was taken from facilities whose SIC codes corresponded with an organic-laden wastewater stream (SIC codes beginning with 20, 26 and 28 - food processing facilities, pulp \& paper mills and chemical plants), and the data was analyzed for CHP potential using the DISPERSE model. Since there was no data on whether or not these facilities already host anaerobic digesters, and due to the fact that industrial plants often employ other wastewater treatment methods, it was assumed that none already possessed a digester.

\subsubsection{Price and Performance Parameters and Load Profiles}

The same price and performance parameters that were used for municipal treatment plants are also used for industrial sites, using the same underlying assumptions. Again, the 1 million gallons per day (MGD) cutoff was applied to select the larger facilities where CHP could offer economic potential. By considering the wastewater treatment operations as a standalone facility within a larger industrial complex, load profiles, genset sizing and operation were deduced using the same methods as municipal wastewater plants. One exception is the pretreatment equipment for industrial plants: since siloxanes are only commonly found at municipal WWTPs and landfills, there would be no siloxane treatment required at industrial WWTPs, and this generally makes up 40-50 percent of the total pretreatment costs. Costs for the anaerobic digester were included in the analysis, estimated at $\$ 1,000$ to $\$ 3,000$ per $\mathrm{kW}$, although some industrial plants already utilize anaerobic digestion.

\subsubsection{Results}

When the Envirofacts database was queried for treatment plants with known organic wastewater streams producing 1 MGD or more, 398 industrial plants were found. ${ }^{175}$ When a $\$ 1,000 / \mathrm{kW}$ anaerobic digester system is included in project economics, only 14 of these plants are capable of returning a positive net present value on their investment. Larger plants and those in states with high electricity prices are generally favored, and the total potential capacity comes out to $7.8 \mathrm{MW}$, all from reciprocating engines. All payback periods fell in the 5-7 year range. When the digester cost is increased to $\$ 3,000$ per $\mathrm{kW}$, none of the industrial treatment plants show economic potential.

Overall, industrial wastewater treatment plants are not recommended for ADG-fueled CHP projects unless there is already a digester installed at the plant. Because industrial WWTPs are not included in the EPA's Clean Watersheds Needs Survey, it is currently unknown which of these plants contain anaerobic digesters, and their relative sizes. Without this data, industrial sites are believed to be limited in their ADG CHP potential, and municipal wastewater treatment plants with anaerobic digesters are seen as much more likely targets for ADG CHP projects.

\subsubsection{Anaerobic Digester Gas from Dairy Farms}

Anaerobic digesters are sometimes used to treat manure on large dairy farms, and these larger farms tend to have a sizeable electric load. Unlike WWTPs, however, the load profiles of dairy farms have two distinct peaks during the day, corresponding to feeding and milking times. If the generator is sized to the peak load, it is under-utilized most of the day, and if it is sized smaller, another power source is required

\footnotetext{
${ }^{175}$ Environmental Protection Agency, Envirofacts Permit Compliance System - Water Discharge Permits, September 2005.
} 
during the peaks. The gas produced by anaerobic digesters on dairy farms is more than enough to power the entire farm, although it is likely that a smaller generator would be more cost-effective than one that powers the entire farm during peak loads.

Data on dairy farms was obtained from a variety of sources, and through this data, some general assumptions and approximations were made. The Census of Agriculture provides data on the number of dairy farms contained in each state, along with their size category. ${ }^{176}$ From various estimates, a single cow produces enough waste to create 0.1 to $0.2 \mathrm{~kW}$ of power with ADG. Therefore, it is estimated that a dairy farm with 200 cows and an anaerobic digester could produce about $30 \mathrm{~kW}$ of power. This is believed to be a reasonable cutoff point, since it is about the size of a small microturbine and a smaller reciprocating engine. The Census of Agriculture categorizes dairy farms as having either 200-500 cows, or more than 500 cows. Within this data, each county, however, is recorded the total number of cows at farms for these categories, as long as there is more than one farm (for proprietary reasons, the Census does not give information for single farms). When the total number of cows is given (i.e. when there is more than one farm in a category), the average is taken. When the total number is not given, the midpoint of 350 cows is taken for farms with 200-500 cows, and for farms with 500+ cows, the lower limit of 500 cows is assumed.

\subsubsection{Price and Performance Parameters}

The same price and performance parameters for CHP systems in wastewater treatment plants are used for dairy farms. Although the gas produced can be slightly different, a heating value of about $600 \mathrm{Btu} / \mathrm{ft}^{3}$ is usually maintained, with the same equipment and maintenance costs defined in Chapter 3. Unlike wastewater treatment plants, farms are not required to treat all of their waste (they can land-apply the waste as a fertilizer or leave it to degrade in a lagoon). So farms can take the liberty of sizing their digester to correspond with their genset(s). For all of the cases analyzed, it is assumed that the digester is sized only to support the genset(s) with the most favorable economics, even if it means some of the farm's waste will not be treated. Anaerobic digester costs of $\$ 1,000$ and $\$ 3,000$ per $\mathrm{kW}$ are used in the analysis, and net metering is incorporated when applicable (the 2006 report did not include a net metering analysis). Siloxane treatment is not required at farms, so pretreatment costs are roughly half of those for municipal wastewater treatment plants. The evaluation does not take into account the added benefits anaerobic digesters can have for farms, such as using digestate as fertilizer, fiber for bedding, improving waste treatment, and reducing greenhouse gas emissions.

\subsubsection{Load Profiles}

While the load profiles for dairy farms vary depending on the equipment used, and how the operation is set up, a general load profile for most dairy farms can be established. From various sources, including the National Food and Energy Council’s guide "Electrical Farm Equipment Demand \& Control Options”177, it appears that a dairy farm with 200 cows has a peak load of approximately $30 \mathrm{~kW}$ to operate, which coincides with the power that a farm of 200 cows could produce with their waste using CHP. A dairy farm with 400 cows, however, would probably only require about $40 \mathrm{~kW}$ to operate (while the cows are capable of producing $60 \mathrm{~kW}$ ). For every additional 200 cows, another $10 \mathrm{~kW}$ required, and another 30 $\mathrm{kW}$ can be produced - so larger dairy farms tend to produce more ADG than they require to operate. As

\footnotetext{
${ }^{176} 2002$ United States Census of Agriculture, United States Department of Agriculture, National Agricultural Statistics Service, http://www.nass.usda.gov/census/census02/volume1/index2.htm

${ }^{177}$ National Food and Energy Council, Electrical Farm Equipment Demand \& Control Options, February 1987.
} 
far as the farm's energy requirements are concerned, each cow on the farm adds about $300 \mathrm{kWh}$ per year. ${ }^{178}$

However, dairy farms do not operate at a constant electric load - there are distinct peaks throughout the day and more energy is used in the summer than the winter. A University of Wisconsin report ${ }^{179}$ provided load curves for several different dairy farms. The general curve for a 400-cow dairy was used and fit to the numbers derived in the preceding paragraph for model implementation. The load profile data was scaled to each dairy farm in the country according to the number of cows, producing estimated hourly loads to serve throughout the year. The original load profile curves are shown in Figure 33.

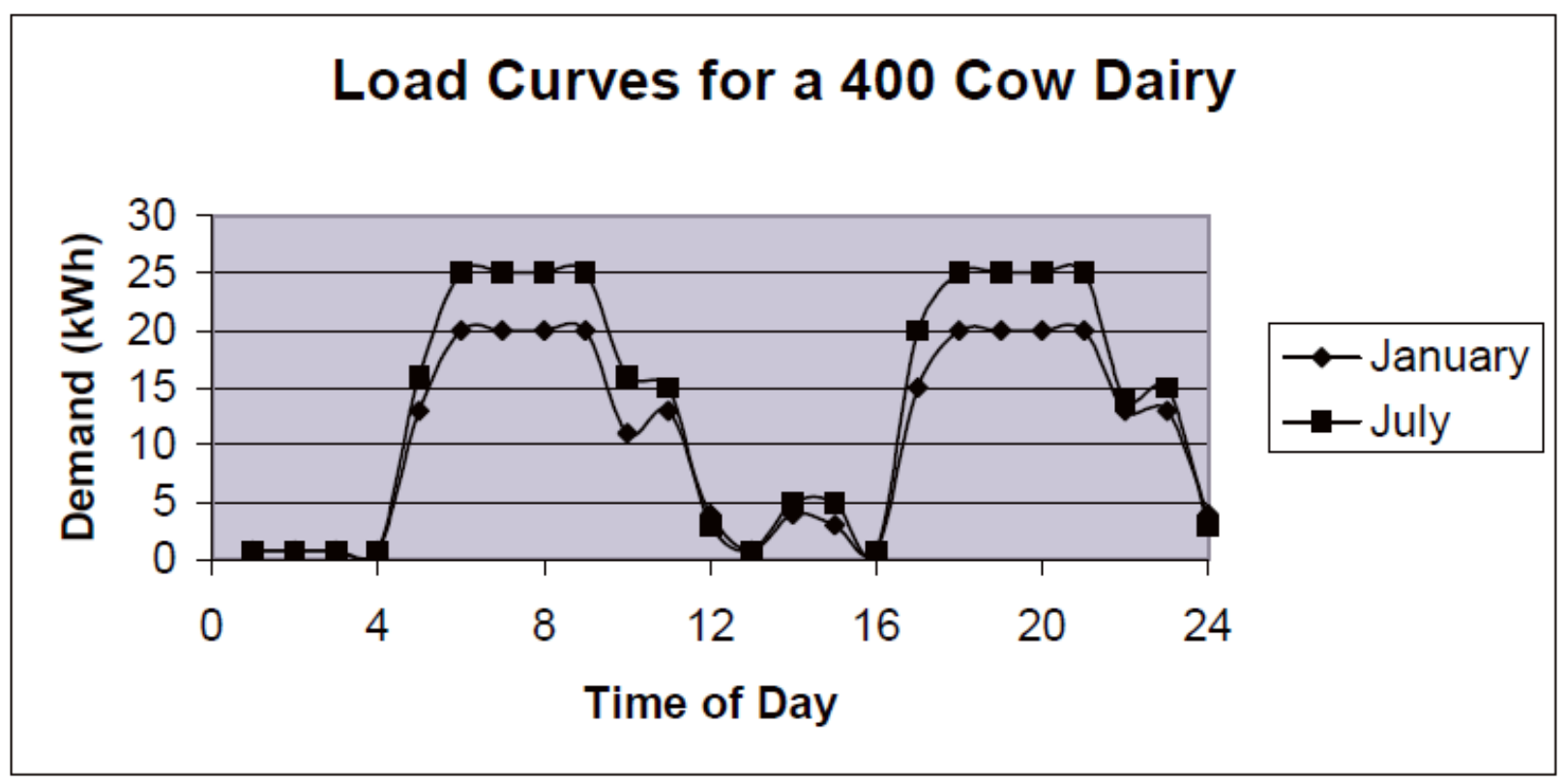

Figure 33. Load Profile for a Typical Dairy Farm

Source: Mehta, Aashish, University of Wisconsin, Department of Agriculture and Applied Economics, The Economics and Feasibility of Electricity Generation using Manure Digesters on Small and Mid-size Dairy Farms, January 2002.

When sizing the CHP system, some different options were considered: sizing it to match the peak, sizing it to half of the peak, and sizing it to the average load. It turned out that sizing the genset to the average load was the most economically beneficial scenario. Using the load profile information, and setting the CHP system to the average $\mathrm{kW}$ demand, the analysis was conducted using the DISPERSE model.

For this 2013 update, net metering was considered for states with net metering laws that include ADG from farms. For net metering applications where participants are paid retail pricing for excess electricity, the genset should be sized closer to the peak load, while allowing the utility to purchase electricity during the off-peak hours. The analysis showed that sizing the generator to the peak load causes the farm to operate as a net seller of electricity, so utilities would only pay the "avoided cost" of electricity for these excess hours, providing limited revenue. Sizing the generator to 80 percent of the peak load allows for a good balance of utility electricity purchases and retail price reimbursements (utilities often credit the full retail rate for excess electricity up to the amount that is purchased by the customer each month - after

\footnotetext{
178 Ibid.

${ }^{179}$ Mehta, Aashsih, University of Wisconsin, Department of Agriculture and Applied Economics, The Economics and Feasibility of Electricity Generation using Manure Digesters on Small and Mid-size Dairy Farms, January 2002.
} 
this, the lower avoided-cost rate is applied). The modeled net metering gensets operate year-round at full capacity, except for the estimated four weeks of unscheduled maintenance.

\subsubsection{Anaerobic Digester Gas from Swine Farms}

Anaerobic digesters are also sometimes used on large hog and hog farms to treat waste manure. Although swine do not produce nearly as much waste as cows, large farms can still produce enough waste to power an ADG genset. The potential ADG fuel from digested hog and hog waste is usually enough to provide electricity to the entire farm. The load profiles of swine farms, however, have very high peaks in demand for short periods during the day, so finding an optimal CHP system size can be even harder than for dairy farms, and it is likely that supplemental power from the utility would be required during peak hours.

The Census of Agriculture was used to determine where the largest swine farms are located. ${ }^{180}$

According to various sources, the waste from a single hog produces anywhere from 0.01 to $0.06 \mathrm{~kW}$ when used to generate power from anaerobic digester gas. However, gas production can vary greatly depending on a number of factors. To date, swine farms have seen the most ADG CHP installations in North Carolina, so data from some of these farms was analyzed to see how the farm size, flow rate, and CHP potential are related. The results are provided in Table 19.

Table 19. ADG Production and CHP Potential for Swine Farms in North Carolina

\begin{tabular}{|l|l|l|r|r|r|}
\hline Farm & Number of Hogs & Digester Type & $\begin{array}{l}\text { ADG Production } \\
\left(\mathbf{f t}^{\mathbf{3}} / \text { day) }\right.\end{array}$ & $\begin{array}{l}\text { Estimated CHP } \\
\text { Potential (kW) }\end{array}$ & $\begin{array}{l}\text { Electricity/Hog } \\
(\mathbf{k W} / \mathbf{h o g})\end{array}$ \\
\hline Loyd Ray Farms & 8,640 sow (farrow to finish) & Covered lagoon, flush tanks & 50,400 & 110 & 0.013 \\
\hline Barham Farm & 4,000 sow (farrow to wean) & Covered lagoon, pull-plug & 33,200 & 73 & 0.018 \\
\hline Carroll's Farm & 1,000 sow (farrow to finish) & Covered lagoon, flush tanks & 29,000 & 64 & 0.064 \\
\hline
\end{tabular}

Sources: United States Environmental Protection Agency, AgSTAR program, Projects: Loyd Ray Farms, September 2012; Biogas Anaerobic Digester Considerations for Swine Farms in North Carolina, North Carolina State University College of Agriculture and Life Sciences, North Carolina Cooperative Extension

From these three farms, the electric capacity per hog ranges from 0.013 to $0.064 \mathrm{~kW}$. Assuming each hog produces the average of $0.03 \mathrm{~kW}$, a farm with 1,000 hogs could produce $30 \mathrm{~kW}$ of power. ${ }^{181}$ This figure is used in the analysis, with a lower limit of 1,000 hogs for potential swine farm CHP projects.

\subsubsection{Price and Performance Parameters}

The same price and performance parameters and assumptions for CHP systems at dairy farms are also used for swine farms, with the same equipment and maintenance costs defined in Chapter 3 . The digester is still sized coincidentally with the CHP system, because farms are not required to treat all of their waste. Net metering is considered for states with net metering rules. The analysis does not take into account the

\footnotetext{
${ }^{180} 2002$ United States Census of Agriculture. United States Department of Agriculture, National Agricultural Statistics Service. http://www.nass.usda.gov/census/census02/volume1/index2.htm

${ }^{181}$ Swine farms in the Census of Agriculture are categorized as either less than or greater than 1,000 hogs or hogs, so this was used as the cutoff point. In cases where there is more than one 1,000-hog farm per county, the total number of hogs is given, and each farm is modeled as the average. In cases where there is only one 1,000-hog farm per county, the number of hogs is not given, so the lower limit of 1,000 hogs is used.
} 
added benefits anaerobic digesters can have for the farm, such as using the digestate as fertilizer and improving their method of waste treatment.

\subsubsection{Load Profiles}

Swine farm load profiles tend to vary more so than dairy farms, according to the equipment that is used and how the hogs are confined. Electric mixer-grinders and related conveyors cause spikes in demand when they are operational. From the National Food and Energy Council's report ${ }^{182}$, some estimates were made on how much electricity hog farms require. A 1,000-hog farm requires about $30 \mathrm{~kW}$ to operate, plus another $10 \mathrm{~kW}$ for every thousand hogs. These are rough estimates, as there are many different types of hog farms, and not all would fit this profile. In general, a swine farm can always generate as much power through ADG fuel as it requires, with the possible exception of during peak feeding hours.

Although information on load profiles for swine farms is limited, the National Food and Energy Council's report has an electrical demand curve corresponding with the time of day for a Minnesota farm with 950 hogs. The electric load for hog farms does not vary much according to time of year, so this is not an issue. The general shape of the curve, shown in Figure 34, was fitted with the data in the previous paragraph to estimate the load profiles for different hog farms in the model.

As with dairy farms, some different approaches were considered for sizing the generator. Again, sizing to the average load proved most beneficial for non-net metering farms, and about 80 percent of the peak load for farms with net metering.

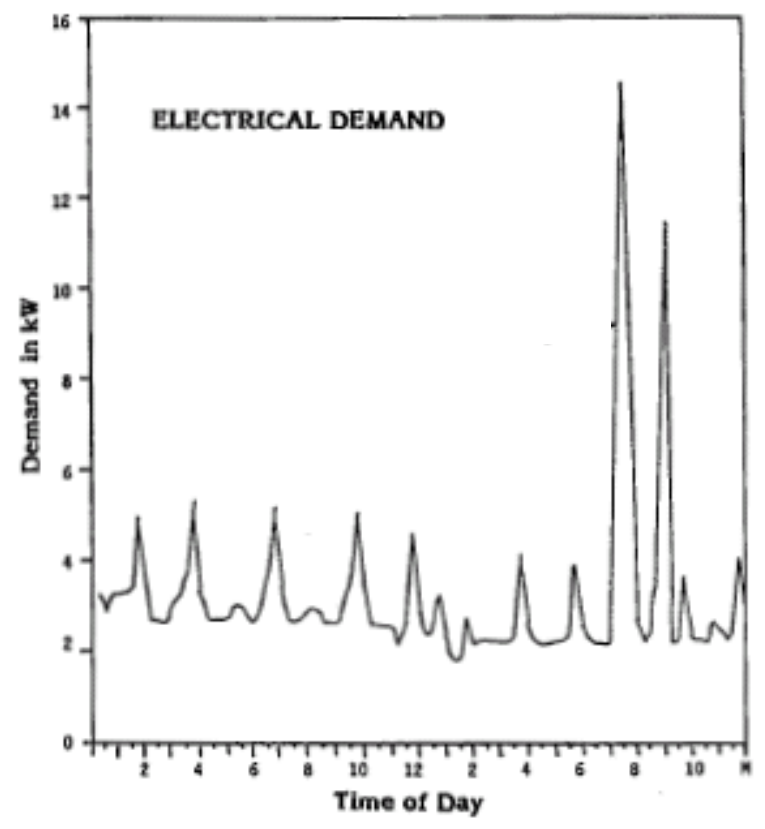

Figure 34. Load Profile for a Typical Swine Farm (950-Head Hog Operation)

Source: National Food and Energy Council. Electrical Farm Equipment Demand \& Control Options. February 1987.

${ }^{182}$ National Food and Energy Council. Electrical Farm Equipment Demand \& Control Options. February 1987. 


\subsubsection{Results for Dairy and Swine Farms}

The results for dairy and swine farms were not as promising as for wastewater treatment plants. As expected, economic potential was only possible with digester costs at $\$ 1,000 / \mathrm{kW}$, with no potential found at the $\$ 3,000 / \mathrm{kW}$ price point. For farms without net metering, only 64 large hog farms in Iowa (4.9 year payback) showed an estimated 1.8 MW of total potential. When net metering was included, with the state-specific rules and estimated avoided-cost prices ${ }^{183}$, several more farms showed potential, especially in California. Overall, 875 farms in California accounted for close to $65 \mathrm{MW}$ of potential capacity when net metering rules were incorporated. Some net metering farms also showed potential in New Hampshire, New Jersey and Pennsylvania, but these only accounted for about $900 \mathrm{~kW}$ of total potential. For all net metering projects, payback periods were in the range of 5-7 years.

While the calculated potential was primarily limited to California, farms with sufficient electric loads in areas with high electricity prices and favorable net metering laws can support ADG CHP projects when some financial assistance is provided. This is evidenced by several farm-based ADG net metering installations throughout New York state that have been supported by the New York Energy Research and Development Authority. Cornell University's College of Agriculture and Life Sciences has conducted several case studies on these farms, with mixed economic results. ${ }^{184}$ Similar incentives have helped farm ADG projects come online in other states, with at least 162 total installations throughout the country. To date, farm-based CHP has been concentrated in Wisconsin, New York and Pennsylvania, with California, Vermont and North Carolina also emerging as strong markets with backing from state incentives. ${ }^{185}$

\subsubsection{Sensitivity: Renewable Energy Credits}

In addition to incorporating net metering into the farm-based ADG analysis, the potential impact of renewable energy credits (RECs) was also considered. Many states have recently adopted renewable portfolio standard (RPS) programs, and most of them work the same way. Each year, utilities in states with RPS programs have an increasing mandate for the amount of renewable electricity in their energy portfolios. Facilities that produce electricity with qualifying renewable fuels or technologies can receive a renewable energy credit for each MWh produced. If utilities do not incorporate the appropriate amount of renewables, they can purchase these RECs from the local energy producers.

For many states, renewable portfolio standards are merely a goal, but several have implemented the market-based REC model, which has proven to be effective. However, states often divide renewable fuels into tiers, with solar and wind power usually taking precedence, often with separate mandates and credits. Biomass fuels (including ADG) are typically in the lower tier of these programs, where REC values are low because the demand is not as high. In most cases, the value of biomass RECs is only a small fraction of a penny per kilowatt-hour.

\footnotetext{
${ }^{183}$ With most net metering rules, excess electricity is purchased at the end of the year at the average avoided cost for the utility (no transmission or distribution costs, just electricity generation) - for this cost, the average 2011 wholesale electricity costs for the nearest power market was used (data was taken from the Energy Information Administration) - average wholesale costs generally ranged from three to five cents per kWh.

${ }^{184}$ Cornell University, College of Agriculture and Life Sciences, Dairy Environmental Systems, Anaerobic Digestion, http://www.manuremanagement.cornell.edu/Pages/Resources/Resources-Case_Studies.htm

${ }^{185}$ A Farm Lives High - and Clean - off the Hog, Zucchino, David, Los Angeles Times, December 25, 2011.
} 
North Carolina's new RPS law singles out swine waste as a renewable energy source, and includes aggressive mandates that should increase REC values and help spur new farm-based ADG projects. ${ }^{186}$ To estimate the potential impact of RPS programs with high value for farm-based ADG, RECs of 1 cent per $\mathrm{kWh}$ were added to the analysis. The results were fairly predictable, with project economics slightly improved across the board, improving payback periods by about half a year.

For the baseload CHP scenario, some large Tennessee and Alabama farms showed promise with the 1 cent per kWh renewable energy credits. However, these states have not yet adopted RPS programs, so near-future potential is unlikely. When states with net metering laws were analyzed, only some Maryland, Pennsylvania, and California farms that were previously on the fringe began to show potential in the 6-7 year range. In other states like North Carolina and New York, payback periods are estimated in the range of 7-10 years with help from REC credits. It should be noted that the RECs were only applied to on-site power use, as the utility would typically own any RECs from net metered electricity, although that is not always the case (i.e. Maryland and New Jersey), and many states with RPS programs leave this issue unaddressed. Also, all of these results include costs for installing a digester.

The results for farm-based ADG are summarized in Figure 35. Without including state incentives, and limiting potential projects to payback periods of seven years or less, the economic market potential is dominated by California farms.

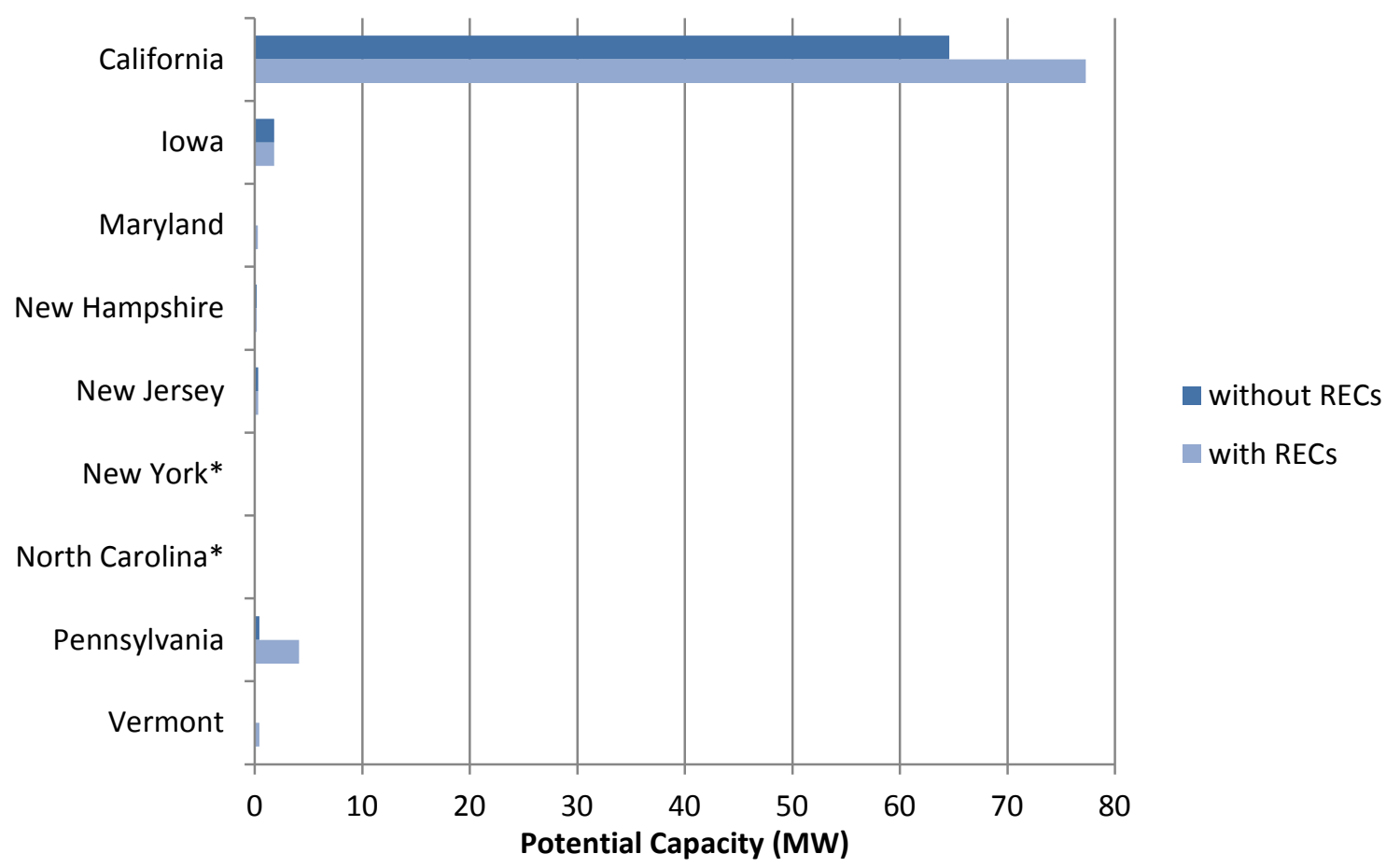

*While no economic potential was found in New York and North Carolina, there have been several recent farm-based ADG CHP installations in these states, aided by state-level incentive programs that were not considered in the analysis. Without these state incentives, payback periods for NY and NC farm projects are estimated in the range of 7-10 years.

Figure 35. Estimated Potential for Farm-Based ADG, with and without RECs at 1 cent/kWh

\footnotetext{
${ }^{186}$ North Carolina Utilities Commission - Renewable Energy and Energy Efficiency Portfolio Standard, http://www.ncuc.commerce.state.nc.us/reps/reps.htm
} 


\subsubsection{Anaerobic Digester Gas Results: All Sources}

Overall, there is between 136 and $270 \mathrm{MW}$ of economic potential for CHP fueled by anaerobic digester gas, depending on which assumptions are made. The majority of potential comes from municipal wastewater treatment plants that can utilize their ADG on-site in a CHP configuration. While the total capacity may not be high, there are certainly a large number of potential ADG projects with strong economics, especially among municipal WWTPs that already utilize anaerobic digestion. Table 20 breaks down the economic potential for ADG by fuel source.

Table 20. Economic Potential for ADG from All Fuel Sources

\begin{tabular}{|l|r|r|}
\cline { 2 - 3 } \multicolumn{1}{c|}{} & \multicolumn{2}{c|}{ Economic Potential (MW) } \\
\hline Source & $\begin{array}{c}\text { Conservative } \\
\text { Estimate }\end{array}$ & $\begin{array}{c}\text { Optimistic } \\
\text { Estimate }\end{array}$ \\
\hline Municipal WWTPs with Digesters & 134 & 177 \\
\hline Municipal WWTPs w/o Digesters & 0 & 16 \\
\hline Industrial WWTPs & 0 & 8 \\
\hline Farms (Dairy and Swine) & 0 & 67 \\
\hline All ADG Sources & 134 & 268 \\
\hline
\end{tabular}

The actual potential for ADG CHP is likely in between these two estimates, but the optimistic estimate of 268 MW will be used in this report's summaries. The vast majority of economic potential comes from municipal wastewater treatment plants with anaerobic digesters already installed, and it is concentrated in areas with high population densities.

\subsection{FOREST RESIDUES}

Forest residues, primarily produced during logging operations, are an abundant source of biomass fuel for certain areas of the country. When forest residues can be collected at the roadside for less than $\$ 40$ per dry $\operatorname{ton}^{187}$, they can be a viable source of fuel for steam and power generation for industrial plants. Forest residues were only considered as a potential fuel for biomass gas in the 2006 report, but with the lack of significant advancement in gasifier technology, solid biomass boiler/steam turbine systems are seen as the most economical option for combined heat and power projects fueled by these woody biomass resources.

\subsubsection{Price and Performance Parameters}

The 2011 Billion Ton Update ${ }^{188}$ provided state-level estimates for available forest residues at price caps of \$20 and \$40 per dry ton. ${ }^{189}$ These were used as the fuel price points in the DISPERSE model, with the amount of resources used as the limitations for total potential (see 6.3.3 Resource Limitations).

Transportation costs for solid fuels have risen considerably in recent years because of inflation and increasing fuel prices. A recent analysis comparing biomass transportation costs by truck versus by rail

\footnotetext{
${ }^{187}$ The estimated "roadside" costs include the significant labor and transportation costs required to make forest residues ready for final truck transportation. This involves tying the wood scraps into bundles and hauling them from the logging operation to the roadside.

${ }^{188}$ U.S. Billion-Ton Update: Biomass Supply for a Bioenergy and Bioproducts Industry, U.S Department of Energy, Oak Ridge National Laboratory, August 2011.

${ }^{189}$ State-level estimates for forest thinnings were provided at \$20/ton and \$40/ton price point, but state-level logging residue resources were only provided at the $\$ 40 /$ ton price point - in order to estimate the amount of logging residues at $\$ 20 /$ ton or less, the national percentage given in the report (28\%) was applied to all state-level numbers.
} 
used 2008 diesel fuel prices ${ }^{190}$ to show that truck transportation of 50 miles now costs about $\$ 22.50$, or 45 cents per ton-mile. ${ }^{191}$ This is an increase of 25 cents per ton-mile, over double the price included in the 2006 report. $^{192}$

Boiler-steam turbine configurations are seen as the only viable option for solid fuel such as biomass at this time, and are the only option considered for this analysis. Capital and maintenance costs for woodfueled steam turbine systems, depending on prime mover size, are outlined in Chapter 3. Overall, costs of boiler/steam turbine systems range from \$2,000 to over \$10,000 per kW, installed, depending on unit size and turbine design. Systems that utilize higher percentages of steam for process heating have higher per$\mathrm{kW}$ costs, but can make up for this with effective steam utilization in CHP configurations. The analysis evaluated extraction turbines that utilize a large portion of their steam for electricity production as well as back-pressure turbines whose steam is primarily utilized for process heating applications.

Extraction turbines were modeled with 20 percent electric efficiency and 50-60 percent total CHP efficiency. It was estimated that only the largest ( $>10 \mathrm{MW}$ ) extraction turbine configuration could reach the 60 percent CHP efficiency necessary for the Federal Investment Tax Credit (ITC). Back-pressure turbines were modeled with a 10 percent electric efficiency and 60 percent CHP efficiency, thus meeting the requirements for the ITC (see related discussion in the Steam Turbines section of Chapter 3).

\subsubsection{Load Profiles}

All commercial and industrial facilities are considered for this analysis, although industrial facilities are more likely candidates for boiler-steam turbine systems. Industrial sites tend to have large thermal demands, including steam for process heating applications, while thermal demand at commercial buildings is generally limited to hot water and space heating. In general, hospitals are the only type of commercial facility with the consistently high thermal demands necessary to incorporate boiler/steam turbine CHP systems.

In the analysis, all commercial and industrial buildings, and their corresponding load profiles, are considered. Load profiles are based on modeled building characteristics and weather files, combined with data from the 2003 Commercial Buildings Energy Consumption Study (CBECS), the 2006 Manufacturing Energy Consumption Survey (MECS), and 2008 County Business Patterns data for location-specific information.

\subsubsection{Resource Limitations}

The quantities of available forest residues were estimated at the county level in 2005 by the National Renewable Energy Laboratory (NREL) ${ }^{193}$, but pricing information is not included in the NREL report. Estimated quantities of forest residues at different price levels are provided at the state level in Oak Ridge National Laboratory (ORNL)'s 2011 Billion Ton Update. ${ }^{194}$ These ORNL estimates are used for the economic analysis, and they are shown in Table 21.

\footnotetext{
190 in 2008, diesel fuel prices in Canada were very similar to the United States - since then, U.S. prices have fallen, and then risen back to 2008 levels.

${ }^{191}$ Short, Harry, Pipes, Trains, and Trucks: How to Move Biomass Cost Effectively, Biofuels and Bio-based Carbon Mitigation, Worldpress.com, http://snrecmitigation.wordpress.com/2009/04/24/pipes-trains-and-trucks-how-tomove-biomass-cost-effectively/

${ }^{192}$ The 2006 report used an older estimate of \$10/ton for 50 miles of truck transportation (20 cents per ton-mile)

${ }^{193}$ Milbrandt, A., A Geographic Perspective on the Current Biomass Resource Availability in the United States, United States Department of Energy, National Renewable Energy Laboratory, Technical Report, December 2005.

${ }^{194}$ U.S. Billion-Ton Update: Biomass Supply for a Bioenergy and Bioproducts Industry, U.S Department of Energy, Oak Ridge National Laboratory, August 2011.
} 
Table 21. Forest Residues Available Annually at \$20/ton and \$40/ton

\begin{tabular}{|c|c|c|c|c|c|c|c|}
\hline \multirow[b]{2}{*}{ State } & \multicolumn{6}{|c|}{ Forest Residues (Thousand Dry Tons) } & \multirow[b]{2}{*}{\begin{tabular}{|c|} 
Maximum \\
Number of $10 \mathrm{MW}$ \\
CHP Facilities* \\
\end{tabular}} \\
\hline & $\begin{array}{c}\text { Forest Thinnings } \\
<\$ 20 / \text { dry ton }\end{array}$ & $\begin{array}{c}\text { Forest Thinings } \\
<\$ 40 / \text { dry ton }\end{array}$ & $\begin{array}{c}\text { Logging Residues } \\
<\$ 20 / \text { dry ton }\end{array}$ & $\begin{array}{c}\text { Logging Residues } \\
<\$ 40 / \text { dry ton }\end{array}$ & $\begin{array}{c}\text { Total Residues } \\
<\$ 20 / \text { dry ton }\end{array}$ & $\begin{array}{c}\text { Total Residues } \\
<\$ 40 / \text { dry ton }\end{array} \mid$ & \\
\hline Alabama & 700 & 900 & 730 & 2,600 & 1,430 & 3,500 & 34 \\
\hline Arizona & 20 & 30 & 20 & 80 & 40 & 110 & 1 \\
\hline Arkansas & 720 & 920 & 530 & 1,900 & 1,250 & 2,820 & 27 \\
\hline California & 430 & 790 & 420 & 1,500 & 850 & 2,290 & 22 \\
\hline Colorado & 20 & 30 & 10 & 40 & 30 & 70 & 0 \\
\hline Connecticut & 0 & 20 & 10 & 20 & 10 & 40 & 0 \\
\hline Delaware & 10 & 20 & 10 & 50 & 20 & 70 & 0 \\
\hline Florida & 380 & 430 & 360 & 1,300 & 740 & 1,730 & 17 \\
\hline Georgia & 950 & 1,190 & 970 & 3,450 & 1,920 & 4,640 & 45 \\
\hline Idaho & 210 & 310 & 180 & 650 & 390 & 960 & 9 \\
\hline Illinois & 10 & 160 & 100 & 350 & 110 & 510 & 5 \\
\hline Indiana & 190 & 290 & 180 & 650 & 370 & 940 & 9 \\
\hline lowa & 0 & 40 & 40 & 150 & 40 & 190 & 1 \\
\hline Kansas & 0 & 5 & 10 & 50 & 10 & 55 & 0 \\
\hline Kentucky & 630 & 800 & 320 & 1,150 & 950 & 1,950 & 19 \\
\hline Louisiana & 470 & 590 & 810 & 2,900 & 1,280 & 3,490 & 34 \\
\hline Maine & 180 & 290 & 780 & 2,800 & 960 & 3,090 & 30 \\
\hline Maryland & 0 & 180 & 60 & 200 & 60 & 380 & 3 \\
\hline Massachusetts & 0 & 20 & 30 & 100 & 30 & 120 & 1 \\
\hline Michigan & 380 & 540 & 310 & 1,100 & 690 & 1,640 & 16 \\
\hline Minnesota & 170 & 190 & 420 & 1,500 & 590 & 1,690 & 16 \\
\hline Mississippi & 640 & 800 & 970 & 3,450 & 1,610 & 4,250 & 41 \\
\hline Missouri & 300 & 520 & 270 & 950 & 570 & 1,470 & 14 \\
\hline Montana & 190 & 290 & 180 & 650 & 370 & 940 & 9 \\
\hline Nebraska & 0 & 20 & 0 & 10 & 0 & 30 & 0 \\
\hline Nevada & 0 & 0 & 0 & 0 & 0 & 0 & 0 \\
\hline New Hampshire & 90 & 180 & 110 & 400 & 200 & 580 & 5 \\
\hline New Jersey & 0 & 0 & 10 & 40 & 10 & 40 & 0 \\
\hline New Mexico & 15 & 20 & 10 & 40 & 25 & 60 & 0 \\
\hline New York & 470 & 720 & 270 & 950 & 740 & 1,670 & 16 \\
\hline North Carolina & 920 & 1,180 & 630 & 2,250 & 1,550 & 3,430 & 33 \\
\hline North Dakota & 0 & 0 & 0 & 0 & 0 & 0 & 0 \\
\hline Ohio & 10 & 370 & 140 & 500 & 150 & 870 & 8 \\
\hline Oklahoma & 110 & 120 & 110 & 400 & 220 & 520 & 5 \\
\hline Oregon & 1,200 & 1,390 & 880 & 3,150 & 2,080 & 4,540 & 44 \\
\hline Pennsylvania & 700 & 1,120 & 410 & 1,450 & 1,110 & 2,570 & 25 \\
\hline Rhode Island & 0 & 0 & 0 & 0 & 0 & 0 & 0 \\
\hline South Carolina & 500 & 620 & 450 & 1,600 & 950 & 2,220 & 21 \\
\hline South Dakota & 15 & 15 & 30 & 100 & 45 & 115 & 1 \\
\hline Tennessee & 830 & 1,100 & 210 & 740 & 1,040 & 1,840 & 18 \\
\hline Texas & 360 & 470 & 390 & 1,400 & 750 & 1,870 & 18 \\
\hline Utah & 10 & 10 & 10 & 20 & 20 & 30 & 0 \\
\hline Vermont & 140 & 180 & 70 & 240 & 210 & 420 & 4 \\
\hline Virginia & 830 & 1,160 & 460 & 1,650 & 1,290 & 2,810 & 27 \\
\hline Washington & 930 & 1,080 & 770 & 2,750 & 1,700 & 3,830 & 37 \\
\hline West Virginia & 410 & 830 & 310 & 1,100 & 720 & 1,930 & 19 \\
\hline Wisconsin & 310 & 420 & 460 & 1,650 & 770 & 2,070 & 20 \\
\hline Wyoming & 20 & 25 & 20 & 80 & 40 & 105 & 1 \\
\hline
\end{tabular}

${ }^{*}$ Assuming extraction steam turbines are used with an effective electric efficiency of 20 percent

Also included in the table are the potential number of $10 \mathrm{MW}$ CHP facilities that could be supported by forest residues at $\$ 40 /$ ton or less, based on extraction steam turbines with an effective electric efficiency of 20 percent. 
Although some states are capable of supporting a large number of CHP projects with forest residue resources, they do not always have favorable economics, especially for biomass resources costing up to $\$ 40 /$ ton. The Southeast and the Northwest have the most forest residue resources, although neither region has particularly strong economic conditions for CHP projects.

To estimate the resources available to the different utility service territories in the DISPERSE model, county-level resource maps from the earlier NREL report were compared to utility service territory maps, and forest residue resources from the updated ORNL study were allocated accordingly to the utilities. Many utilities that are located in urban areas or arid regions of the country that lack forest resources were effectively eliminated from the analysis as their territories offered little forest resources.

Potential industrial and commercial sites located in each utility service territory with substantial forest residue resources were analyzed with the DISPERSE model, assuming average transportation distances of 10 and 50 miles. The utility-specific resource limitations were used to provide limits on the possible potential, assuming an average of 7,000 Btu/lb for all dry forest residues. ${ }^{195}$

Pulp and paper mills, as well as wood product manufacturers, were not included in the pool of potential sites for the initial economic analysis. These facilities produce wood waste products that they tend to process and utilize on-site for boiler fuel. The majority of biomass boiler installations to date have been located at pulp and paper mills or wood manufacturing plants. While there may be a few opportunities for traditional CHP projects in these sectors, especially at pulp and paper mills where there is often a nearby surplus of potential waste fuel resources (most on-site resources are already being fully utilized), in general these sites already use CHP. However, there could be opportunities for these facilities to install large CHP systems, and sell excess electricity to the local utility grid. These types of facilities already have the capability to receive and process large amounts of biomass feedstock for boiler fuel, with welltrained work forces of operators and engineers. Pulp and paper mills and wood product manufacturers are analyzed separately as a special power export case that takes these considerations into account.

Other than the power export cases, when a facility shows potential in the DISPERSE model, it is crossreferenced with a database of known biomass-fueled CHP installations ${ }^{196}$, and eliminated from consideration if it matches up with an existing project (between 50 and 150\% of modeled CHP capacity). When this happens, other potential project(s) are identified and chosen from the DISPERSE results in an attempt to fully utilize each utility area’s estimated forest residue resources.

\subsubsection{Results for Industrial Facilities, Not Including Power Export}

Industrial facilities located close to low-cost forest residue resources can economically benefit from installing a biomass boiler/steam turbine CHP system. When assuming only 10 miles of average fuel transportation, $652 \mathrm{MW}$ of economic CHP potential from boiler/steam turbine systems is found. When a 50-mile average transportation distance is assumed, the potential drops to $235 \mathrm{MW}$. More often than not, back-pressure steam turbines producing less electricity but more thermal output produced the most favorable project economics. Extraction turbines that produce more electricity provided the best option in some cases, however, typically for larger CHP projects. Florida and Pennsylvania, with plentiful forest resources and favorable economics, show a large amount of potential. Washington state and North

\footnotetext{
${ }^{195}$ Green forest residues are nearly 50 percent moisture, and have an energy content of about 4,500 Btu/lb. Bonedry residues contain about 8,000 Btu/lb. Forest residues used for fuel are usually somewhere in between, at about 20 percent moisture and 7,000 Btu/lb.

${ }^{196}$ ICF International, Combined Heat and Power Installation Database, 2013, http://www.eea-inc.com/chpdata/
} 
Carolina have plentiful forest residues, but economics are not as favorable, so 50-mile transportation would not feasible. The potential for the top twelve states is broken down in Figure 36.

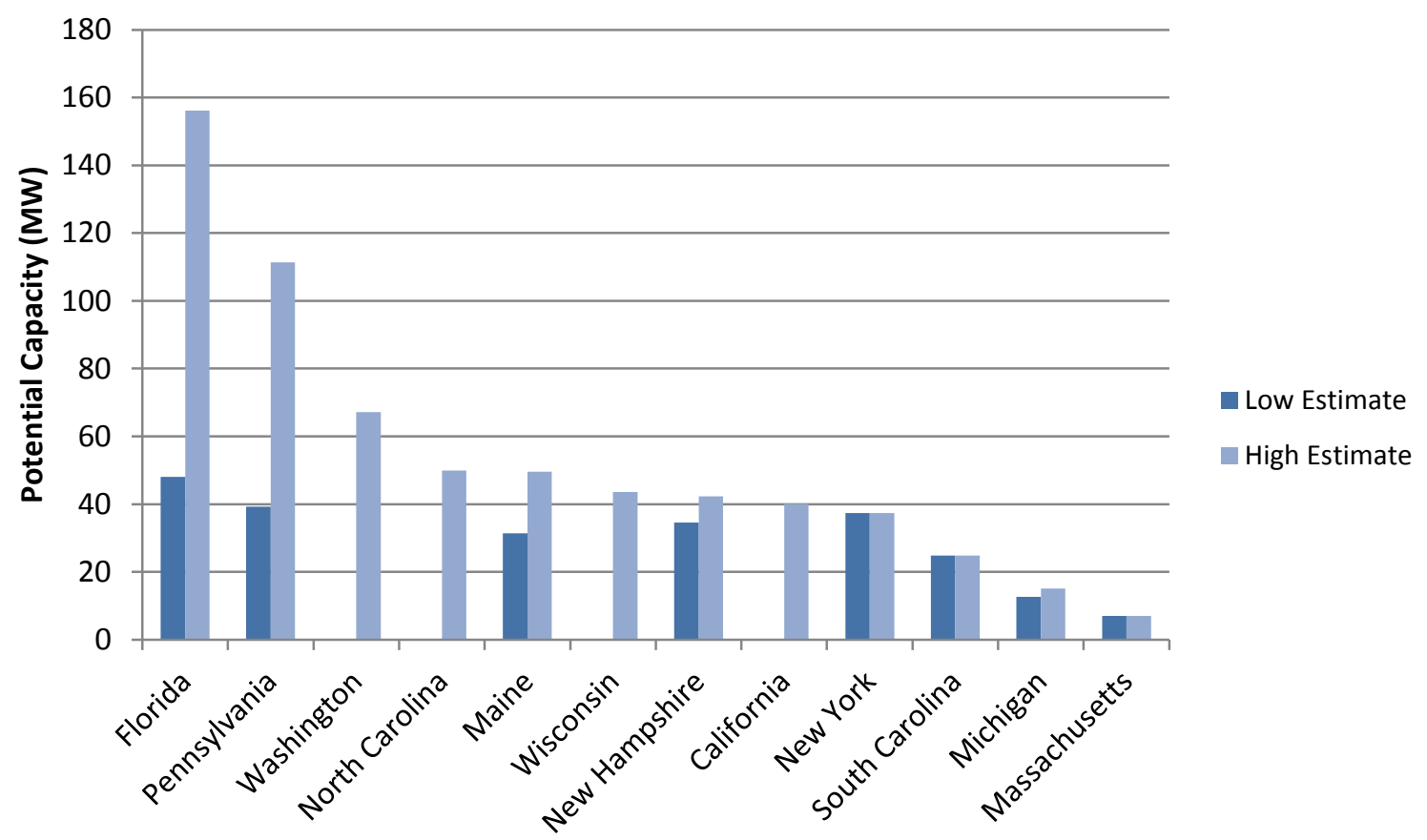

Figure 36. Economic Potential for Forest Residue CHP Applications: Top Twelve States (Not Including Power Export)

The optimistic results (assuming a 10-mile average transportation distance) are broken down by industrial facility type in Figure 37.

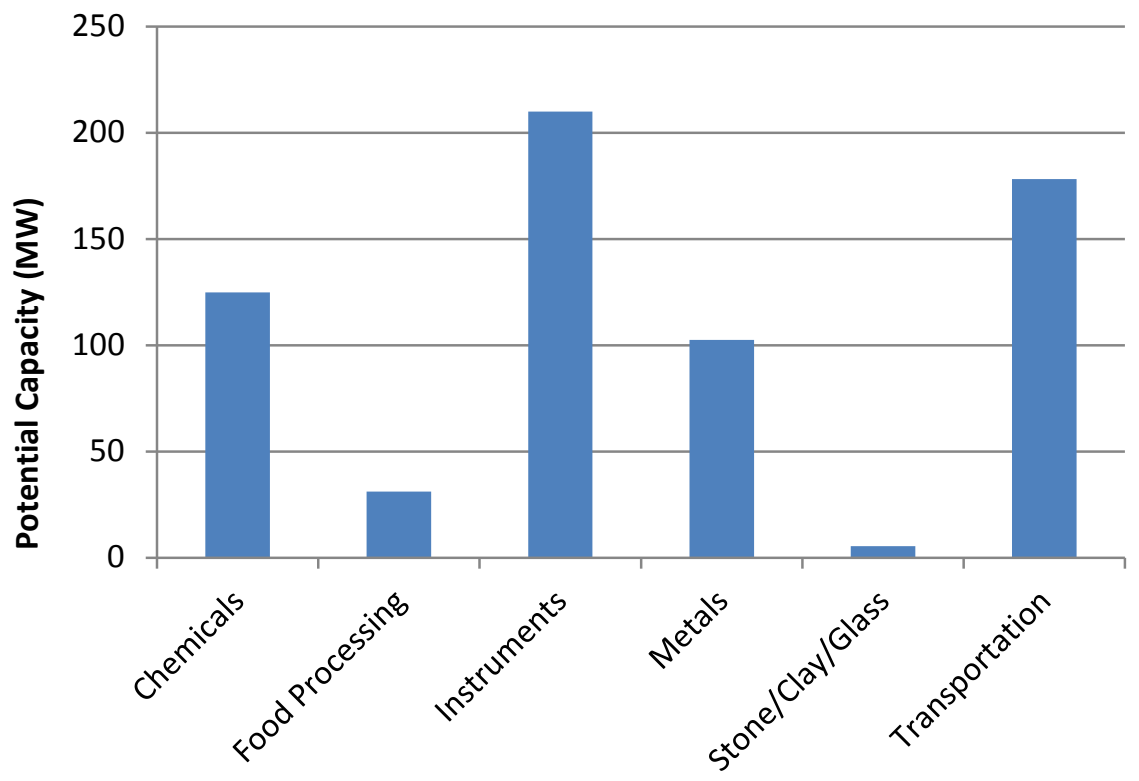

Figure 37. Economic Potential for Forest Residue CHP Applications, by Facility Type (Not Including Wood or Paper Products) 
All of these facilities have substantial thermal loads that can be met with steam or hot water production, and sufficient electric demand to support combined heat and power. In many cases, there were industrial facilities from other sectors that could have also shown potential, but due to resource limitations, only the facilities with the lowest payback periods and highest net present values on their investments were selected. For most of these projects, payback periods are over 5 years, limiting their appeal. Payback period ranges for both the 10-mile and 50-mile average transportation distance are broken down in Figure 38. Pulp and paper mills and wood manufacturing facilities were not included in this analysis due to their abundant on-site biomass resources and current utilization practices - they are considered in the power export scenario later in this chapter.

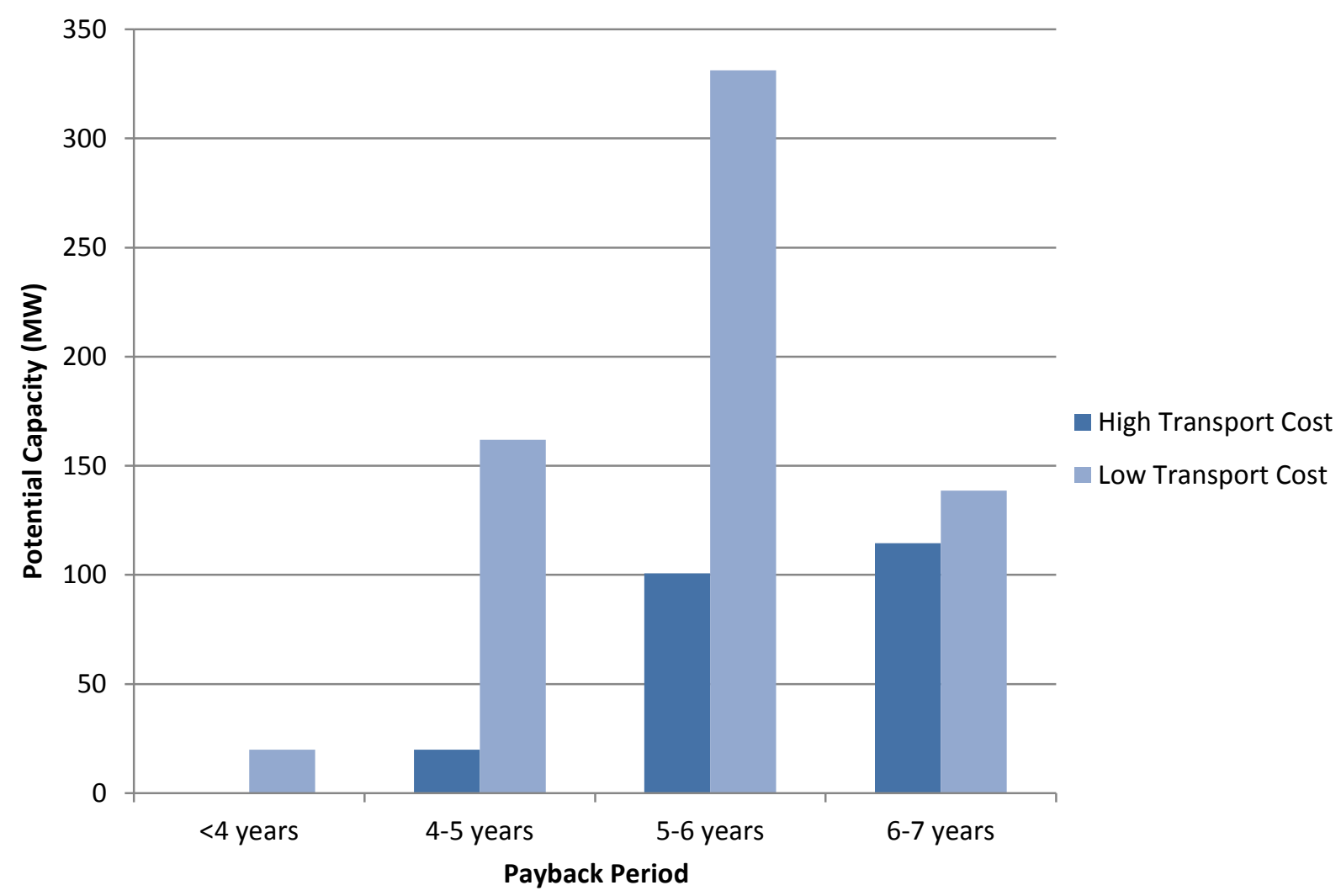

Figure 38. Payback Periods for Forest Residue CHP Applications (No Wood or Paper Products)

The facilities able to achieve a payback period of 5 years or below are presented in Table 22. The results are for an average transportation distance of 10 miles. When the transportation distance is increased to 50 miles, only two sites, one in New Hampshire and one in Massachusetts, come in at under 5 years. 
Table 22. Industrial Sites with Forest Residue CHP Payback Periods of Five Years or Less (10-mile transport, No Wood or Paper Products)

\begin{tabular}{|c|c|c|c|c|c|c|c|c|c|}
\hline Facility Type & State & Utility & \begin{tabular}{|} 
Estimated \\
Facility Size \\
$(\mathrm{kW})$
\end{tabular} & $\begin{array}{c}\text { CHP Size } \\
(\mathrm{kW})\end{array}$ & $\begin{array}{c}\text { Applicable } \\
\text { Facilities }\end{array}$ & $\begin{array}{c}\text { Extraction or } \\
\text { Back- } \\
\text { Pressure? }\end{array}$ & $\begin{array}{c}\text { Annual } \\
\text { Electricity } \\
\text { (MWh) }\end{array}$ & $\begin{array}{c}\text { Annual } \\
\text { Fuel Use } \\
\text { (MMBtu) }\end{array}$ & $\begin{array}{c}\text { Payback } \\
\text { (years) }\end{array}$ \\
\hline Food Processing & New Hampshire & Public Service NH & 3,210 & 1,240 & 1 & Back-Pressure & 10,869 & 370,877 & 3.5 \\
\hline Instruments & New Hampshire & Public Service NH & 55,160 & 18,700 & 1 & Back-Pressure & 150,254 & $5,126,964$ & 3.8 \\
\hline Chemicals & Michigan & Consumers Energy & 27,670 & 12,650 & 1 & Back-Pressure & 110,786 & $3,780,236$ & 4.1 \\
\hline Transportation & Maine & Central Maine & 43,910 & 14,450 & 2 & Extraction & 126,550 & $4,318,134$ & 4.2 \\
\hline Instruments & Florida & Florida Power Corp & 55,160 & 18,700 & 1 & Back-Pressure & 150,254 & $5,126,964$ & 4.3 \\
\hline Chemicals & New Hampshire & Public Service NH & 6,220 & 2,840 & 2 & Back-Pressure & 24,893 & $1,698,765$ & 4.3 \\
\hline Chemicals & New Hampshire & Public Service NH & 2,730 & 1,250 & 1 & Back-Pressure & 10,923 & 372,711 & 4.3 \\
\hline Food Processing & Maine & Central Maine & 3,210 & 1,240 & 1 & Back-Pressure & 10,869 & 370,877 & 4.3 \\
\hline Chemicals & Florida & Florida Power Corp & 26,700 & 12,200 & 1 & Back-Pressure & 106,897 & $3,647,525$ & 4.4 \\
\hline Primary Metals & Pennsylvania & Penelec & 27,350 & 11,080 & 1 & Back-Pressure & 97,030 & $3,310,858$ & 4.4 \\
\hline Chemicals & Massachusetts & Massachusetts Electric & 3,030 & 1,380 & 1 & Back-Pressure & 12,132 & 413,973 & 4.4 \\
\hline Primary Metals & New Hampshire & Public Service NH & 14,150 & 5,730 & 1 & Back-Pressure & 50,213 & $1,713,384$ & 4.5 \\
\hline Food Processing & Massachusetts & National Grid (MA) & 8,210 & 3,170 & 1 & Back-Pressure & 27,745 & 946,726 & 4.7 \\
\hline Food Processing & Massachusetts & National Grid (MA) & 3,210 & 1,240 & 2 & Back-Pressure & 10,869 & 741,754 & 4.7 \\
\hline Instruments & New York & National Grid (NY) & 55,160 & 18,700 & 2 & Back-Pressure & 150,254 & $10,253,928$ & 4.8 \\
\hline Chemicals & Maine & Central Maine & 2,810 & 1,290 & 1 & Back-Pressure & 11,262 & 384,289 & 4.8 \\
\hline Instruments & Washington & Puget Sound & 55,160 & 18,700 & 1 & Back-Pressure & 150,254 & $5,126,964$ & 5.0 \\
\hline & & Totals & 393,050 & 144,560 & 21 & & $1,212,054$ & $47,704,928$ & \\
\hline
\end{tabular}

\subsubsection{Special Case: Power Exporting with Pulp and Paper Mills, Wood Product Manufacturers}

For facilities like pulp and paper mills that produce and utilize biomass waste fuels on-site, the economics for CHP systems using forest residues are not as straightforward. Recently, some paper mills have installed oversized boiler/steam turbine systems, purchasing additional biomass fuels from nearby resources to produce large amounts of steam and excess electricity for utility sales. These applications tend to involve large steam turbines, 20 to $75 \mathrm{MW}$ in size. Different factors for sizing include the availability of nearby biomass resources, the facility's electric and thermal demands, and the potential revenue from electricity sales. For many states, renewable energy credits (RECs) can provide additional incentives. In some cases, utilities have partnered with mills to provide funding for the projects, under the condition that they own the electricity (and the RECs as well). ${ }^{197}$

While this power export strategy has become attractive for large pulp and paper mills, it is questionable if it would also work for wood product manufacturers. Manufacturers of wood products produce a large amount of wood waste fuels that are generally utilized to their fullest extent for on-site heat and power. Pulp and paper mills require vast quantities of steam for daily operations, and utilize multiple boiler configurations with different fuels ${ }^{198}$, which is not the case for most wood product manufacturers, so large extraction steam turbine configurations may not be practical.

197 “We Energies plans biomass plant at Domtar Rothschild Mill site”, Wisconsin Energy Corporation News, September 1, 2009, http://wecnews.wisconsinenergy.com/news/newsreel/pages/newsrelease_143

${ }_{198}$ In this scenario, a pulp and paper facility with multiple boilers was analyzed. A power boiler fueled by either coal or woody biomass is usually the largest, providing the most steam to the mill, and sometimes electricity through 
A preliminary economic analysis was conducted for wood product manufacturers, based on typical electric and thermal requirements and forest residues at \$20/dry ton, with a 10-mile average transportation distance. The large-scale power export strategy would only be feasible for the largest wood processing facilities in areas with extremely high wholesale electricity prices. Unfortunately, wood product manufacturers do not tend to locate large industrial facilities in high-price urban areas, and the only U.S. location with electricity prices high enough for attractive economics in this scenario is Hawaii. Similar strategies employed at a smaller scale $(<10 \mathrm{MW})$ were not able to achieve attractive project economics in any realistic pricing scenario.

For pulp and paper mills, however, there are many facilities that are large enough to support CHP steam turbines significantly greater than $10 \mathrm{MW}$ in size, utilizing all of the steam while exporting the majority of the electricity. There are currently eight paper mills with new CHP systems either already functioning or in the construction process. These mills, with their paper processing capacities (in annual tons) and steam turbine sizes (in MW of electric capacity) are presented in Table 23. On average, the CHP systems were sized at about $100 \mathrm{~kW}$ per thousand annual tons of paper processed.

Table 23. Pulp and Paper Mills Installing New Steam Turbine CHP Systems

\begin{tabular}{|c|c|c|c|c|c|}
\hline Paper Mill & City & State & $\begin{array}{c}\text { Paper Processing } \\
\text { Capacity } \\
\text { (1000 tons/yr) } \\
\end{array}$ & $\begin{array}{c}\text { CHP Capacity } \\
\text { (MW) }\end{array}$ & $\begin{array}{c}\text { Size Factor } \\
\text { (MW per } 1000 \\
\text { annual tons) } \\
\end{array}$ \\
\hline Domtar Marlboro Mill & Bennettsville & SC & 389 & 50 & 0.13 \\
\hline Domtar Rothschild Mill & Rothschild & WI & 132 & 37 & 0.28 \\
\hline Graphic Packaging International Macon Mill & Savannah & GA & 558 & 40 & 0.07 \\
\hline Meadwestvaco Covington Mill & Covington & VA & 950 & 75 & 0.08 \\
\hline Nippon Paper Industries Port Angeles Mill & Port Angeles & WA & 166 & 20 & 0.12 \\
\hline Simpson Tacoma Kraft Tacoma Mill & Tacoma & WA & 400 & 55 & 0.14 \\
\hline Verso Paper Bucksport Mill & Bucksport & ME & 486 & 25 & 0.05 \\
\hline Verso Paper Quinnesec Mill & Norway & $\mathrm{Ml}$ & 374 & 28 & 0.07 \\
\hline & & Totals & 3,455 & 330 & 0.10 \\
\hline
\end{tabular}

Source for paper processing capacity: Georgia Tech Center for Paper Business and Industry Studies Data Center, October 2013

There are a number of factors that go into the decisions of how to size the CHP system for this scenario, with the most important being the estimated amount of nearby biomass resources. It is unlikely that steam turbines larger than $75 \mathrm{MW}$ would be sustainable due to this factor. Also, a nearby utility must be willing to either purchase excess electricity from the mill or own the project and its electricity, with the paper mill purchasing the steam. Areas with high electricity prices and state renewable portfolio standards provide the most attractive economics. Finally, the pulp and paper mill must see some benefit from the new CHP installation - for most mills, this would come from outsourcing the acquisition and maintenance of the boiler/steam turbine system to the utility, and purchasing steam and electricity at a discounted contract rate. One scenario would be to replace their power boiler and their wood waste boiler

an extraction turbine. The mill analyzed also has a secondary "hog fuel” boiler fueled by wood waste, as well as a "recovery boiler" fueled by black liquor. Finally, the mill has a gas-fueled boiler that is only used to its fullest extent during periods of peak output. Existing back-pressure turbines can be fed by these three smaller boilers, and these turbines would continue to be utilized in the power export CHP scenario. Only the coal and wood-fueled boilers would be replaced with the oversized CHP system. 
(also called a hog fuel boiler) with the CHP system. The recovery boiler, fueled by black liquor, and the gas boiler, used during peak production periods, would remain in use at the mill. This is illustrated in Figure 39.

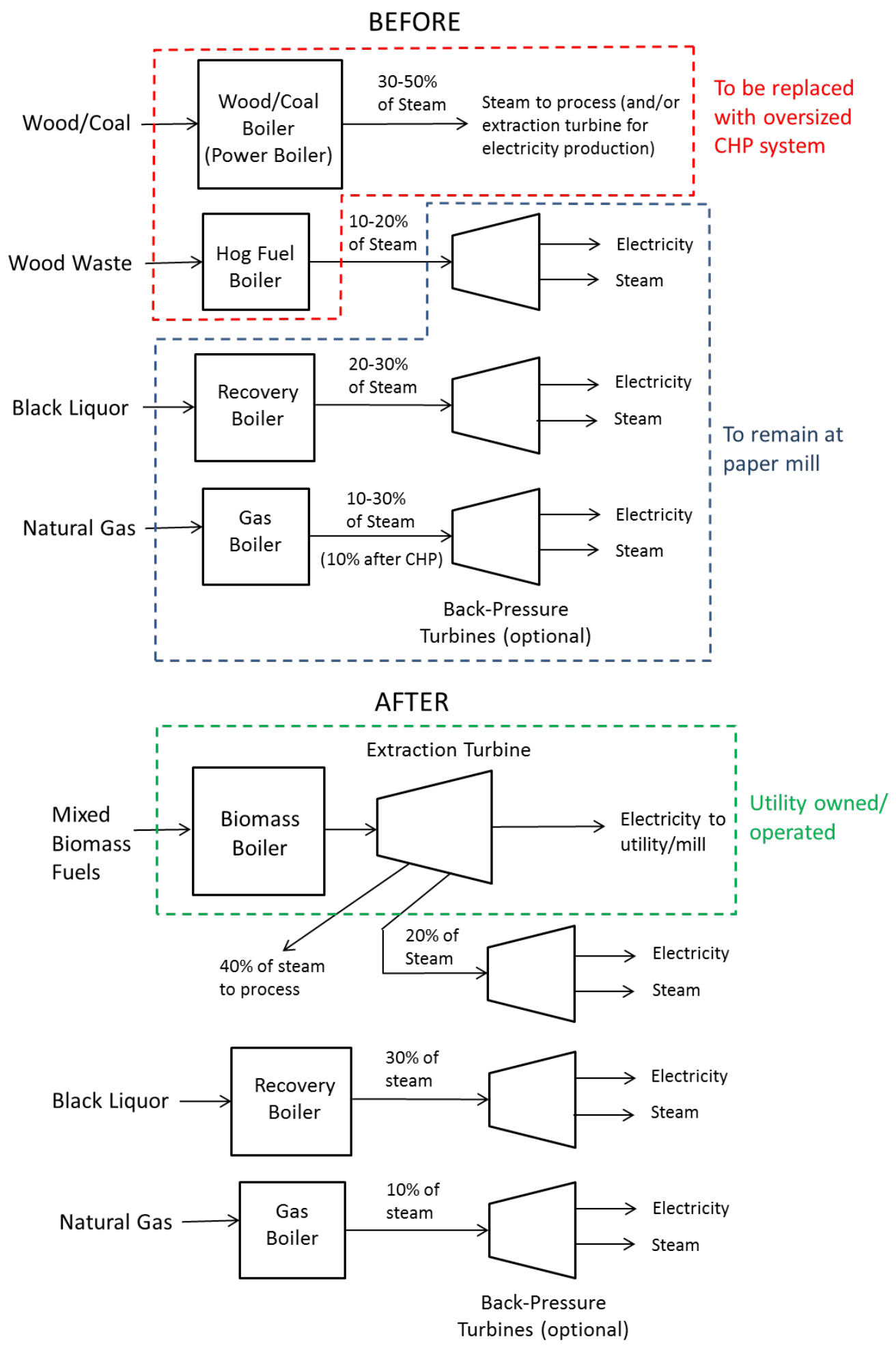

Figure 39. Configuration of Paper Mill Boilers and Turbines Power Export Scenario, Before and After CHP 
Using the average figure of $100 \mathrm{~kW}$ per thousand annual tons of paper production from the analysis of recent CHP installations, a comprehensive database of United States paper mills was analyzed for CHP potential. ${ }^{199}$ All mills processing over 100,000 annual tons (capable of supporting a 10 MW CHP system) were included in the analysis. For all installations, an effective electric efficiency of 20 percent (with a total CHP efficiency near 60 percent) is assumed, and a cap of $75 \mathrm{MW}$ (for sites processing more than 750,000 tons/year) is used. Also, paper mills are assumed to source one third of the necessary biomass fuel on-site, with the remaining two thirds purchased from nearby forest residues.

Without considering resource limitations, the estimated CHP potential comes in at $7.2 \mathrm{GW}$, with a large portion potentially coming from purchased forest residues. However, when resource limitations and economic considerations are implemented, only a fraction of this potential is achievable.

In order to conduct the economic market analysis, some general assumptions were made:

1. Utilities collaborate with paper mills for project planning, and finance the CHP system in full. Electricity and steam produced by the new CHP unit is owned by the utility.

2. Electricity from the CHP unit is valued at the average wholesale rate (3-4.5 cents $/ \mathrm{kWh}$, depending on location). The electricity may or may not be sold to the mill, depending on their previous configuration and their electricity requirements. As a sensitivity, half of the electricity will be sold to the mill at a discounted rate (relative to retail rates, higher than the wholesale rate) to make up for displaced mill electricity - this would be beneficial to the utility.

3. All of the steam from the CHP units is sold to the collaborating paper mill(s) at a typical rate for large industrial customers (\$6 per thousand pounds of steam).

4. All systems are eligible for the Federal Production Tax Credit (1.1 cents/kWh). For states with renewable energy credit trading, an additional 0.5 cents per $\mathrm{kWh}$ is applied.

5. The CHP system uses a large stoker boiler designed for biomass fuels, along with extraction turbine(s) at a net electric efficiency of 20 percent, and a total CHP efficiency of 60 percent. The effective cost of the boiler/steam turbine system is $\$ 3,500 / \mathrm{kW}$, with 2 cents $/ \mathrm{kWh}$ for maintenance costs (see Chapter 3 for detailed price and performance parameters).

6. Based on typical plant configurations and data from the Nippon Paper Industries CHP installation ${ }^{200}$, about two-thirds of the biomass fuel resources will come from newly purchased biomass resources, while onethird of the biomass will come from existing mill fuel. An average transportation distance of 10 or 25 miles is assumed for purchased forest residue resources.

7. Required fuel purchases and maintenance costs are compared to potential electricity and steam sales, along with the estimated installed cost of the CHP system. When the payback period for a large boiler/steam turbine system is estimated at less than 10 years for a given state, all of the paper mills in that state are assumed to have economic potential, although this would be limited by the amount of available forest residue resources.

8. Forest residue resources that were utilized in the general economic analysis are subtracted from the available resources for pulp and paper mills, so as not to double-count the potential - for most states with paper mills, there are plentiful forest residue resources.

Using these assumptions and guidelines, the economic potential was evaluated for paper mills in each state. Wholesale electricity prices for U.S. markets in 2012 were found to average between 3 cents $/ \mathrm{kWh}$ (Louisiana, Southern Texas) and 4.5 cents/kWh (New England, Mid-Atlantic). ${ }^{201}$ Based on all of the available data, each state was assigned an average wholesale electricity price of 3.0 cents, 3.5 cents, 4.0 cents, or 4.5 cents per kWh. States with renewable energy credit trading were given credits of 0.5 cents

\footnotetext{
${ }^{199}$ Georgia Tech Center for Paper Business and Industry Studies: Database of United States Pulp and Paper Mills, October 2013.

${ }^{200}$ City of Port Angeles, Nippon Paper Industries Biomass Co-generation Facility Final Environmental Impact Statement, September 3, 2010.

${ }^{201}$ United States Department of Energy, Energy Information Administration, Electricity: Wholesale Market Data, October 2013, http://www.eia.gov/electricity/wholesale/index.cfm
} 
per kWh for all electricity produced. Steam is typically sold to large industrial customers for around \$6 per thousand pounds of steam, or $\$ 5$ per MMBtu, so this number was used for all potential projects.

When the data was analyzed, up to $1.1 \mathrm{GW}$ of economic potential was found for forest residue applications at up to 50 U.S. pulp and paper mills. ${ }^{202}$ Some states showed favorable economics, but the lack of available forest residue resources prevented them from reaching the minimum of $10 \mathrm{MW}$, so they were not included in the results. ${ }^{203}$ The states with the most potential are identified in Table 24, along with the maximum number of paper mills that could potentially benefit from CHP installations. All estimated payback periods fell in the 7-10 year range, which utilities may be willing to take on (as opposed to industrial facilities, which generally prefer payback periods of less than five years on large investments).

Table 24. Economic Potential for New CHP Installations at Pulp and Paper Mills using Forest Residues and Mill Resources

\begin{tabular}{|l|c|c|}
\hline \multicolumn{1}{|c|}{ State } & $\begin{array}{c}\text { Economic } \\
\text { Potential } \\
\text { (MW) }\end{array}$ & $\begin{array}{l}\text { Maximum } \\
\text { Number of } \\
\text { Installations* }\end{array}$ \\
\hline Oregon & 191 & 6 \\
\hline North Carolina & 189 & 4 \\
\hline Virginia & 187 & 7 \\
\hline Texas & 109 & 4 \\
\hline Washington & 88 & 8 \\
\hline California & 84 & 4 \\
\hline Minnesota & 54 & 5 \\
\hline Indiana & 46 & 3 \\
\hline Maine & 43 & 4 \\
\hline Wisconsin & 20 & 2 \\
\hline Missouri & 20 & 1 \\
\hline Illinois & 14 & 1 \\
\hline Vermont & 11,056 & 50 \\
\hline United States & 509 & 1 \\
\hline
\end{tabular}

*Based on number of mills and $10 \mathrm{MW}$ minimum size

\footnotetext{
${ }^{202}$ New forest residue resources provide two-thirds of the total fuel for the oversized CHP system - the remaining third comes from wood fuels that the mill was already assumed to be utilizing. The potential reflects the total capacity, using both fuel sources.

${ }^{203}$ When economic market potential for forest residue-fueled CHP was shown for other industrial sites in the initial analysis, those resources are not considered in this special case analysis. For example, all of New York's \$20/ton forest residue resources were utilized in the initial market analysis, so potential for paper mills was not possible using forest residues at this price point. Economics at $\$ 40 /$ ton were unfavorable, leaving no potential for New York paper mills.
} 
All of these results assume an optimistic average fuel transportation distance of 10 miles for forest residue resources. When the distance is increased to 25 miles, only $170 \mathrm{MW}$ of potential is possible, concentrated in high-electricity-price areas like California and New England. The combined economic potential for forest residues, using optimistic estimates, is presented in Figure 40.

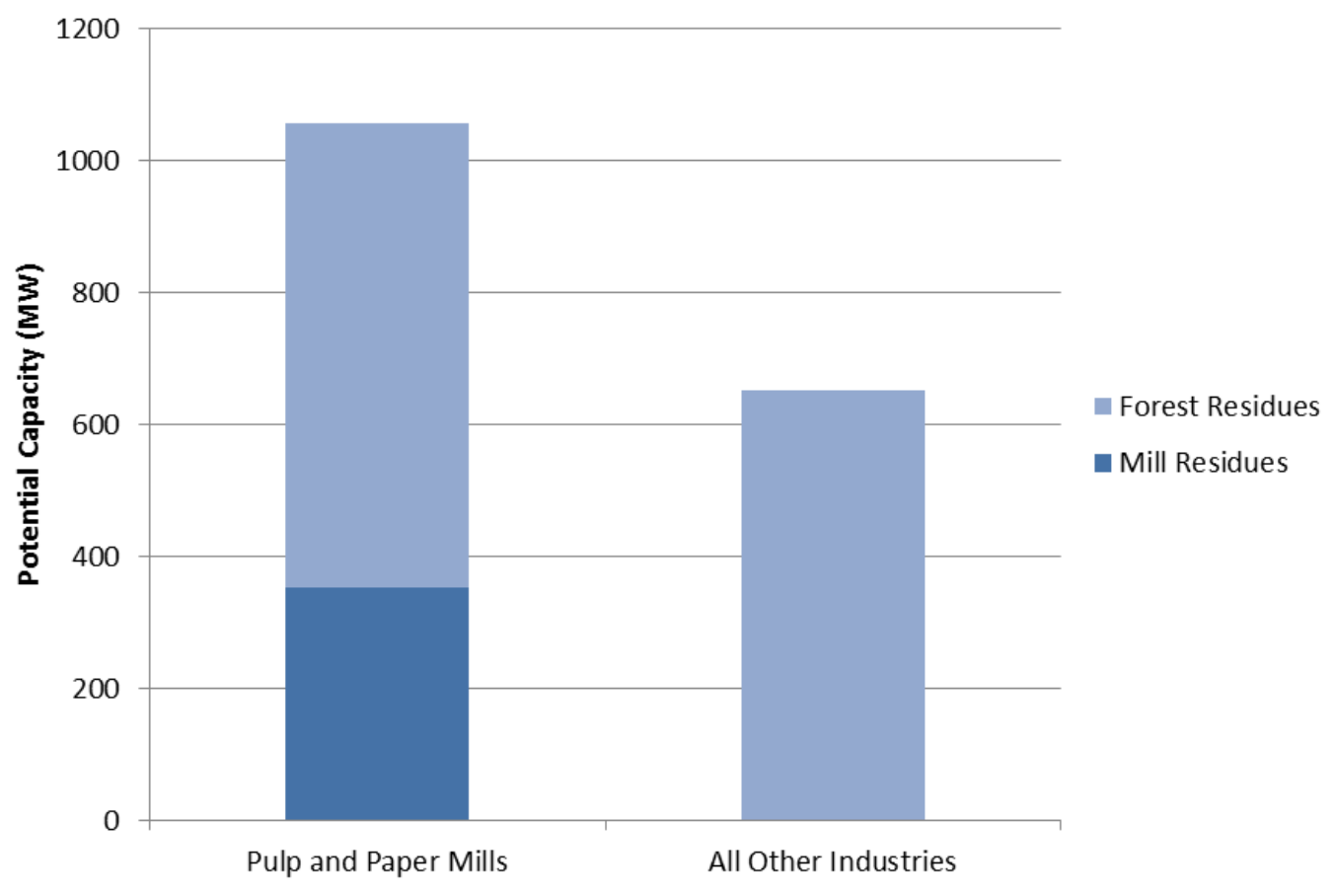

Figure 40. Economic Potential for CHP from Forest Residues with CHP Power Export Scenario (Optimistic Estimates)

A sensitivity analysis was performed to determine how the economic potential would increase if utilities were replacing mill-produced electricity, selling a large portion of power from the new CHP systems at a discounted rate, higher than the wholesale rate that was previously assumed.

\subsubsection{Sensitivity: Replacing Mill-Produced Electricity}

Some pulp and paper mills use their power boilers to produce electricity with extraction steam turbines. For these facilities, at least some of the electricity from a new oversized CHP system would be replacing electricity that was previously produced on-site. Under the utility ownership scenario, all of the electricity and steam produced by the CHP system would belong to the utility. Paper mills may be reluctant to replace on-site electricity with purchased power, but utilities could potentially offer a substantial discount. For typical pulp and paper mills, about half of the electricity generated from the new oversized steam turbine would be replacing electricity that was previously produced on-site. ${ }^{204}$

\footnotetext{
${ }^{204}$ This assumes that the pulp and paper mill follows the configuration outlined in Figure 39, with the power boiler fueling an extraction turbine.
} 
An internal analysis showed that large paper mills tend to pay about 15 percent less than the state average industrial electricity price. An additional 20 percent discount was applied to this figure for each state, for half of the electricity sales from the new CHP unit. The other half of electricity sales are valued at the wholesale rate, as in the base case analysis. Because the details of paper mill power production are unknown, this scenario was applied to all potential pulp and paper mill CHP installations, resulting in improved economics from the utility's perspective.

Overall, 2-2.5 GW of CHP potential could be realized if all of the pulp and paper mills are currently utilizing extraction turbines to produce some of their own power. This is a best-case scenario, and it is likely that economics for the majority of mills would be closer to the base case scenario, where up to $1.1 \mathrm{GW}$ of potential was found.

\subsubsection{Summary: Forest Residues}

Overall, forest residues are a promising opportunity fuel that could be used economically for CHP in areas with high residue concentrations and low collection costs. The combined economic potential for all forest residue CHP applications is estimated at between $400 \mathrm{MW}$ and $1.7 \mathrm{GW}$. However, most facilities would be unable to achieve a payback period below 5 years under current market conditions, especially if the average transportation distance is greater than 10 miles. Most of the potential for forest residues (up to $1.1 \mathrm{GW}$ ) comes from opportunities for utility-collaborated boiler/extraction steam turbine CHP systems that export power and offer payback periods in the 7-10 year range. Otherwise, the majority of potential sites would likely utilize back-pressure steam turbines in the 1-10 MW size range to take advantage of nearby forest residue resources. Facilities that can support larger systems ( $>10 \mathrm{MW}$ ) could utilize a combination of back-pressure and extraction steam turbines, depending on their thermal and electric requirements.

\subsection{LANDFILL GAS}

Although landfill gas (LFG) is already being utilized as a fuel in several hundred applications throughout the United States, there is room for further utilization, with over 1,400 landfills that the EPA has deemed as candidate or potential sites for LFG energy projects. Unlike wastewater treatment plants, landfills do not have intensive electric or thermal demands, so possible CHP projects usually need to be sited at a nearby facility with higher energy requirements or within a short distance to a transmission line to export power to the grid. Due to gas pipeline construction costs, the nearby facilities that utilize LFG tend to be located within 5 miles of the landfill site, although some recent industrial projects have incorporated pipelines well over 10 miles in length.

A landfill's current waste-in-place (measured in tons) determines roughly how much LFG is produced, which in turn determines how much energy can be created. The EPA's Landfill Methane Outreach Program (LMOP) Database lists most of the landfills currently operating in the United States, including the amount of waste-in-place and LFG project status (operational, construction, shut down, candidate, or potential). Only sites listed as candidate or potential are considered in this analysis. While waste-in-place data was available for most active landfills, it was not available for all - for landfills lacking this data, the median value of 1,000,000 tons of waste in place was used. Overall, there are 1,763 landfills in the LMOP database listed as candidate or potential landfills that are large enough for CHP applications. ${ }^{205}$

205 “candidate” landfills have been deemed strong candidates for LFG energy projects, while "potential” landfills are seen as having potential, but have not been thoroughly reviewed. 
For sites with known existing or planned LFG energy projects, the estimated gas flow to the project was subtracted from the total estimated LFG flow.

The EPA's Landfill Methane Outreach Program Database provides the locations of the landfills, and the Census Bureau's County Business Patterns (CBP) database provides business data for nearby operational facilities, including county location and employee size range. The analysis looks at these as potential host CHP sites that can use LFG as a fuel. Since multiple commercial businesses often occupy a single building or building complex (i.e. a commercial CBP data point often represents an unknown percentage of some larger commercial building), and because industrial facilities have large electric and thermal demands, only CBP data for manufacturing sites were used as possible matches for LFG CHP projects. Additionally, industrial facilities are often located far from residential areas, closer to landfills, while commercial buildings tend to be located in urban areas where pipeline construction can be especially difficult and costly. Taking these factors into account, the CBP data was probed for manufacturing facilities within the county of each landfill, matching estimated electric loads with potential LFG utilization, and most of the landfills were able to find a matching host industrial site.

In theory, nearly any large industrial facility located within 5 miles of a large landfill could support construction of a pipeline and utilize their LFG, with the economic incentive of a low-cost fuel source. Gas pipeline costs are more a function of length, less related to LFG volume, so smaller landfills that produce less LFG could have trouble supporting long pipeline installations. Additionally, there could be issues with right-of-way and land ownership along a pipeline's projected path, which could necessitate additional pipeline construction. In practice, it can be difficult to reach long-term agreements with industrial sites, which is one of the reasons the majority of LFG energy projects to date have involved electricity sales rather than industrial utilization.

\subsubsection{Price and Performance Parameters}

Landfill gas performs very similarly to anaerobic digester gas with most CHP options, so similar price and performance parameters can be used. The estimated equipment and maintenance costs for LFGpowered CHP systems are provided in detail in Chapter 3. With landfill gas projects, the main impediments are the cost to construct pipelines and gas collection equipment. While larger landfills typically have LFG collection equipment in place, since they are required to either flare or utilize their gas, landfills with less than 2.75 million tons of waste-in-place do not fall under federal regulations. This gives an advantage to larger landfills, who will not have to install additional gas collection equipment. According to the EPA, gas collection equipment costs approximately $\$ 600,000$ per million tons of wastein-place. For all landfills, pipeline construction costs are estimated at $\$ 330,000$ per mile ${ }^{206}$, and with a lack of detailed location data, and pipelines both 2-miles and 5-miles in length are considered in the analysis, which are reasonable pipeline lengths considering that the landfill and the industrial host sites evaluated are located in the same county. Also, because not all landfills require siloxane treatment, a lower-cost option for no siloxane treatment is considered. In the previous 2006 opportunity fuel analysis, pipeline costs were estimated at \$260,000 per mile, and pretreatment costs were not as high.

Landfill gas, which is typically sold in its raw and unfiltered form to third parties for $\$ 1-\$ 3$ per $\mathrm{MMBtu}^{207}$, is assumed to cost an average of $\$ 2.00 / \mathrm{MMBtu}$ for most industrial applications. While conducting research for the 2006 study, no-cost access to LFG was commonplace, but as the market for landfill gas has continued to grow stronger, landfills have started negotiating compensation for access to

\footnotetext{
${ }^{206}$ LFG Energy Project Development Handbook. US EPA Landfill Methane Outreach Program. 2010.

${ }^{207}$ Biomass Catalog of Combined Heat and Power Technologies. United States Environmental Protection Agency Combined Heat and Power Partnership. September 2007.
} 
their LFG. Between the higher pipeline cost estimates, higher pretreatment costs, the added cost to obtain the gas, and higher estimates for CHP equipment in general, project economics were severely affected for industrial LFG utilization in this updated report.

\subsubsection{Load Profiles}

The LFG CHP analysis is unusual in that the starting point is the CHP system size, and not a customer facility size. In order to find a potential manufacturing facility, the analysis assumed that a baseline $30 \%$ electric efficient generator (LHV) should serve between 30 and $85 \%$ of the facility's peak electric load. The majority of landfills were matched with a manufacturing facility to use a sizeable percentage of the potentially available LFG supply within the same county.

No favor was given to a manufacturing facility based on its particular NAICS classification, although food processing facilities were most commonly matched with landfill sites based on location and electric demand. At the rather broad 3 digit NAICS level, manufacturing facilities with the same electric $\mathrm{kW}$ demand in the same county do not tend to vary greatly in the potential electricity bill savings from a baseloaded CHP project, assuming the facility offers sufficient thermal demand that does not limit the CHP system's operation.

\subsubsection{Results}

When installing a 5-mile pipeline at $\$ 330,000$ a mile (\$1,650,000 total investment) and including siloxane pretreatment equipment, 39 industrial sites located near landfills are able to achieve a positive net present value on LFG CHP systems, with a total potential capacity of $97 \mathrm{MW}$. For a more optimistic estimate, a 2-mile pipeline $(\$ 660,000)$ and no siloxane treatment were assumed, and this yielded significantly more potential, with 139 sites showing 209 MW of potential. The potential came primarily from reciprocating engines, but for projects over $5 \mathrm{MW}$ in size, combustion turbines proved the more economical option. This reflects to a large degree the types of units already installed at U.S. landfills.

California has more LFG CHP potential than any other state. However, it should be noted that the counties in California cover large areas of land, so industrial sites located in the same county as a landfill could be more likely to require long pipelines compared to other states. Also, California has a very aggressive Renewable Portfolio Standard, and many top candidate landfills have recently engaged in energy projects. All California landfills with at least $1 \mathrm{MW}$ of project potential were individually researched for recent LFG energy projects, and many of them had to be removed from consideration due to current engagements not captured in the LMOP database. Still, the economics and opportunities in California make it an ideal location for LFG CHP installations. The top fifteen states for new LFG CHP projects are detailed in Figure 41. 


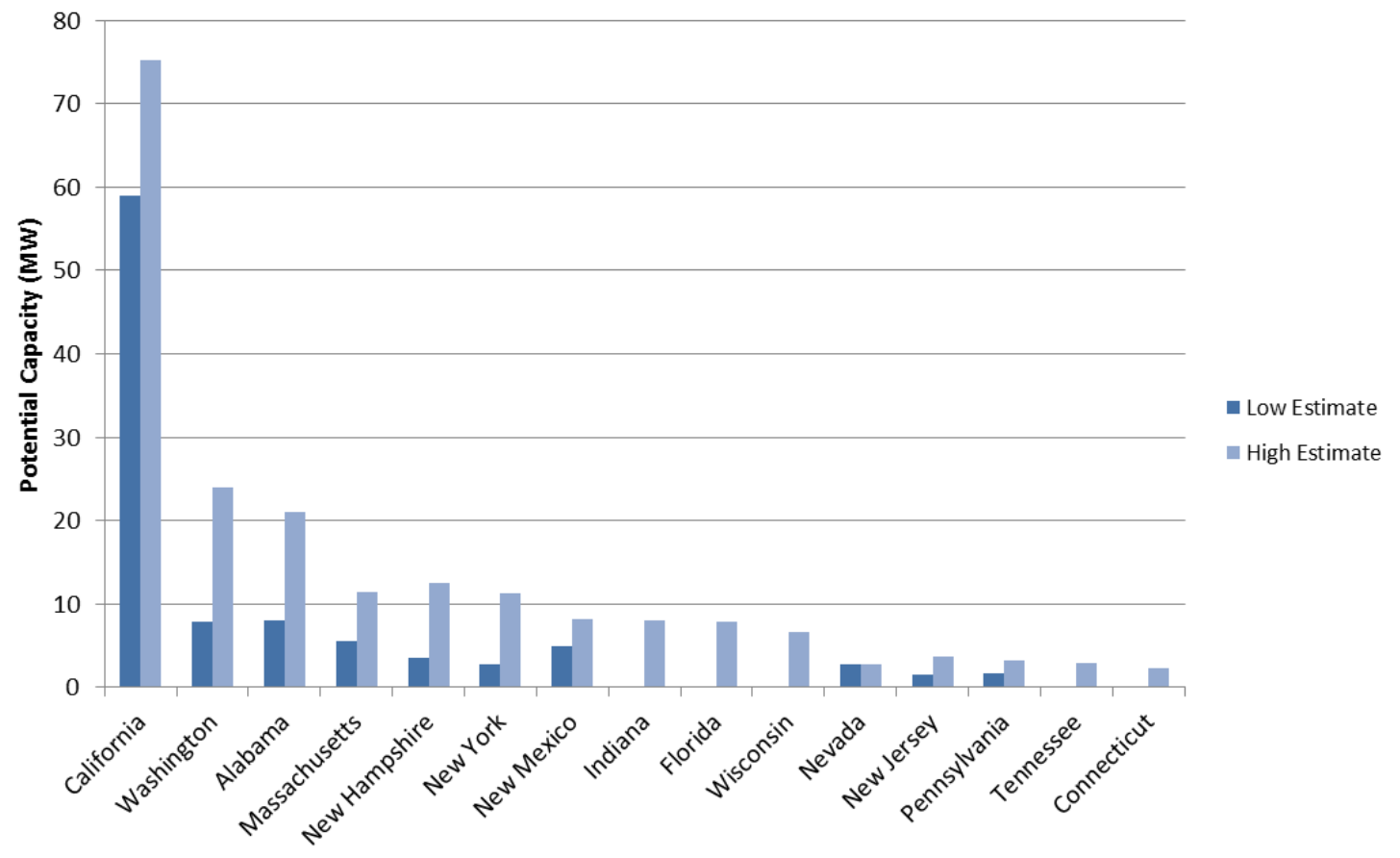

Figure 41. Economic Potential for LFG CHP Applications: Top Fifteen States

Payback periods for LFG projects were obviously more favorable when 2-mile pipelines are used and no siloxane pretreatment equipment is required (as opposed to 5-mile pipelines and full pretreatment costs). In the low installation cost scenario, 31 sites show $67 \mathrm{MW}$ potential with payback periods below four years, while in the high cost scenario, only 7 sites and $20 \mathrm{MW}$ of potential are in this range. The distribution of payback periods ranges for both scenarios is provided in Figure 42.

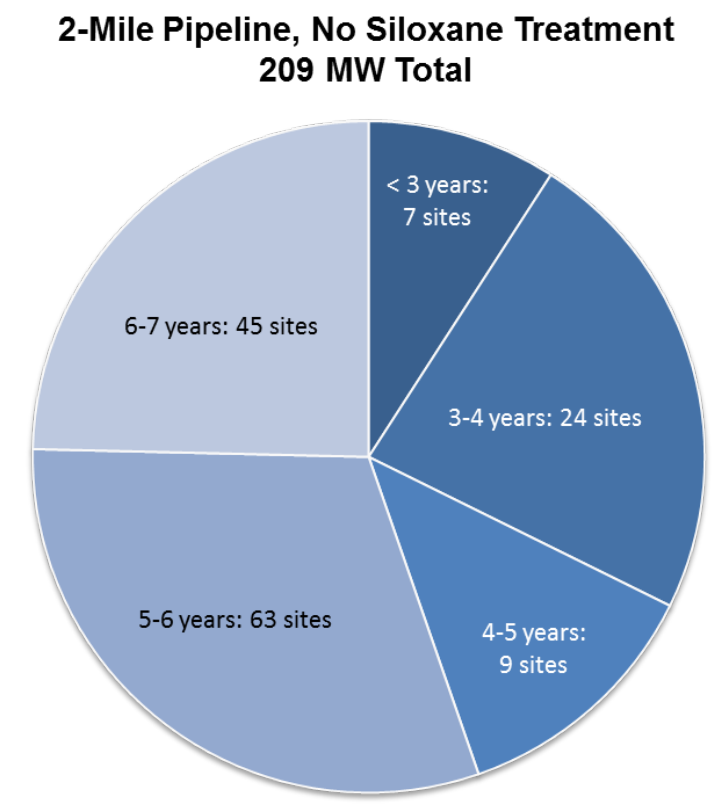

\section{5-Mile Pipeline, Full Pretreatment 97 MW Total}

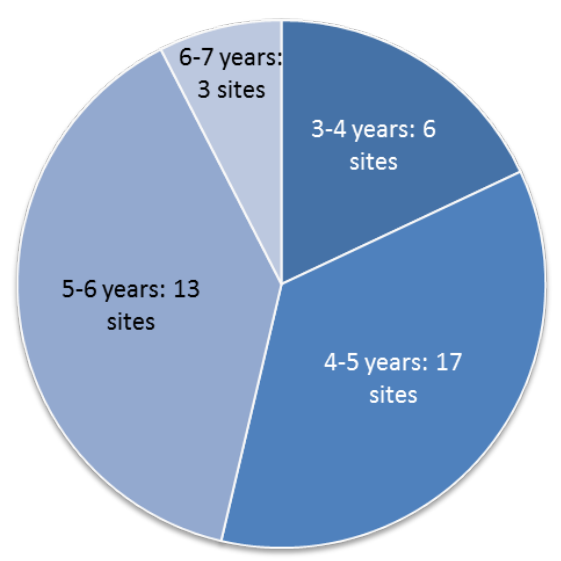

Figure 42. Payback Period Ranges for LFG CHP Projects 
For most potential LFG projects, the model selected reciprocating engines as the most cost-effective technology, with the vast majority falling in the 1-5 MW range. Larger sites were able to incorporate combustion turbines. The breakdown of the optimistic estimate (209 MW) by size range and technology is provided in Figure 43.

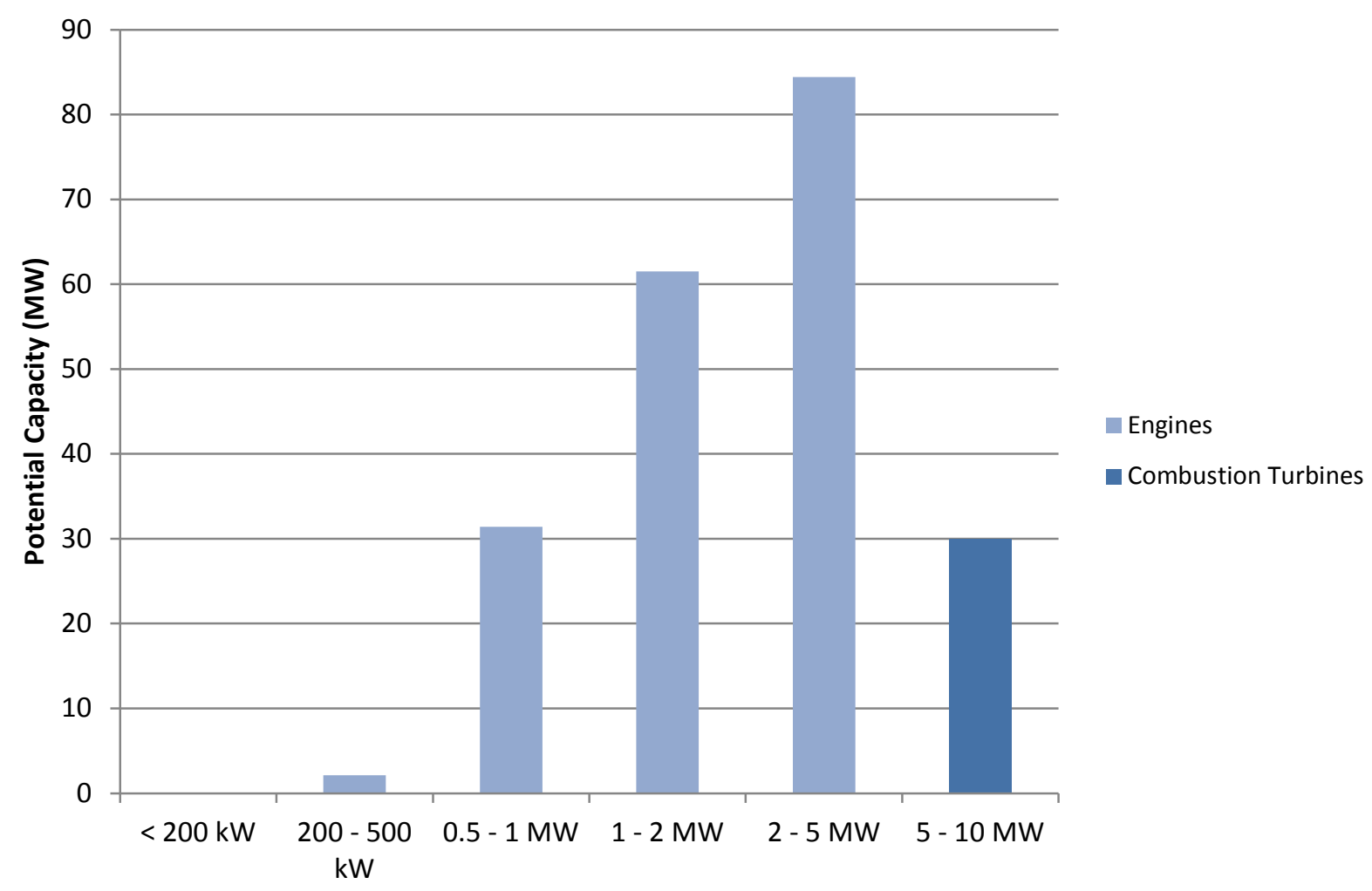

Figure 43. Landfill Gas CHP Potential by Technology and Size Range (Optimistic Estimate)

For landfills that can produce at least 1 MW with LFG, nearby industrial sites with sufficient electric and thermal demand should be able to economically benefit, especially if no siloxane treatment is required.

\subsection{URBAN WOOD WASTE}

Although many pulp and paper mills, wood product manufacturers and lumber processing facilities produce wood waste on-site and have easy access to the fuel, most of these facilities already utilize the majority of their wood waste for energy. Urban wood waste, however, should be readily available near population centers in every state, and its low price makes it a legitimate fuel option for CHP boiler-steam turbine applications.

Because urban wood waste comes from a variety of different sources, the heat content of the fuel can vary considerably. Most sources of urban wood waste produce a dried fuel with a heat content of 6,000-7,500 $\mathrm{Btu} / \mathrm{lb}$, but urban brush and tree clearings (which typically contain more moisture and less woody 
biomass) tends to produce fuel with a heat content of only 4,000-5,000 Btu/lb. ${ }^{208}$ The EPA's Biomass CHP Catalog of Technologies ${ }^{209}$ estimates the average heating value of urban wood waste at 6,150 Btu/lb on a dry basis. However, many other sources report urban wood waste heating values in the range of $7,000 \mathrm{Btu} / \mathrm{lb}$. For the purposes of this report, an average heating value of $6,500 \mathrm{Btu} / \mathrm{lb}$ is assumed for all urban wood waste fuels.

\subsubsection{Price and Performance Parameters}

According to REPP-CREST ${ }^{210}$, urban wood waste and mill residues cost approximately \$1 per MMBTU, or \$15-\$20 per dry ton, to obtain. These figures apply to all U.S. locations, as the cost of collecting the waste fuels is roughly the same at each site. Transportation costs for solid fuels, using an older estimate of \$10 per 50 miles (20 cents per ton-mile) via truck in the 2006 analysis, have risen considerably in recent years because of inflation and increasing fuel prices. An analysis comparing biomass transportation costs by truck versus by rail used 2008 diesel fuel prices ${ }^{211}$ to show that truck transportation of 50 miles now costs about $\$ 22.50$, or 45 cents per ton-mile. ${ }^{212}$ This is over double the estimate that was used in the 2006 report.

For this analysis, transportation distances of 10 and 25 miles, and their effective cost differences, are used to provide estimates for urban wood waste utilization potential from industrial sites located close to population centers. In order to estimate the amount of wood waste available for the different utilities represented in the DISPERSE model, the populations of metropolitan statistical areas in the different territories was used to estimate the percentage of the state's available urban wood waste resources, as estimated by the National Renewable Energy Laboratory in $2005 .{ }^{213}$ See "Resource Limitations" later in this section for a full explanation of the process.

Since wood waste is a solid fuel, only boiler-steam turbine configurations are considered for this analysis. Capital and maintenance costs for wood-fueled steam turbine systems, depending on prime mover size, are outlined in Chapter 3. Costs of boiler/steam turbine systems range from $\$ 2,000$ to over $\$ 10,000$ per $\mathrm{kW}$, installed, depending on unit size and a number of other factors. Systems that utilize higher percentages of steam for process heating have higher per-kW costs, but can make up for this with effective steam utilization. The DISPERSE model evaluated extraction turbines that utilize a large percentage of their steam for electricity production as well as back-pressure turbines whose steam is primarily utilized for process heating applications.

Extraction turbines were modeled with 20 percent electric efficiency and 50-60 percent total CHP efficiency. It was estimated that only the largest (>10 MW) extraction turbine configuration could reach

\footnotetext{
${ }^{208}$ Study of Processing and Utilizing Urban Wood Waste and Pallets for Fuel in the State of Illinois. M.L. Smith Environmental, Inc. and Associates, prepared for Council of Great Lakes Governors Regional Biomass Energy Program. January 1995.

${ }^{209}$ Biomass Combined Heat and Power Catalog of Technologies. United States Environmental Protection Agency Combined Heat and Power Partnership. September 2007.

${ }^{210}$ Costs of Bioenergy. Renewable Energy Policy Project \& Center for Renewable Energy and Sustainable Technology, http://www.repp.org/bioenergy/link5.htm, May 2011.

${ }^{211}$ in 2008, diesel fuel prices in Canada were very similar to the United States - since then, U.S. prices have fallen, and then risen back to 2008 levels as of early 2012.

${ }^{212}$ Short, Harry, Pipes, Trains, and Trucks: How to Move Biomass Cost Effectively, Biofuels and Bio-based Carbon Mitigation, Worldpress.com, http://snrecmitigation.wordpress.com/2009/04/24/pipes-trains-and-trucks-how-tomove-biomass-cost-effectively/

${ }^{213}$ Milbrandt, A., A Geographic Perspective on the Current Biomass Resource Availability in the United States, United States Department of Energy, National Renewable Energy Laboratory, Technical Report, December 2005.
} 
the 60 percent CHP efficiency necessary for the Federal Investment Tax Credit (ITC). Back-pressure turbines were modeled with a 10 percent electric efficiency and 60 percent CHP efficiency, thus meeting the requirements for the ITC (see related discussion in the Steam Turbines section of Chapter 3).

\subsubsection{Load Profiles}

All commercial and industrial facilities are considered for this analysis, although industrial facilities are more likely to install a boiler-steam turbine CHP system. Industrial sites tend to have large thermal demands, including steam for process heating applications, while thermal demand at commercial buildings is generally limited to hot water and space heating. In general, hospitals are the only type of commercial facility with the consistently high thermal demands necessary to incorporate boiler/steam turbine CHP systems.

In the analysis, all commercial and industrial buildings, and their corresponding load profiles, are considered. Load profiles are based on typical building characteristics and weather data, combined with information from the 2003 Commercial Buildings Energy Consumption Study (CBECS), the 2006 Manufacturing Energy Consumption Survey (MECS), and 2008 County Business Patterns data for location-specific information.

\subsubsection{Resource Limitations}

Urban wood waste resources available by state are estimated in a 2005 NREL report. ${ }^{214}$ The location of these resources directly correlates with population density, so the percentage of a population located within a metropolitan statistical area (MSA) compared to the entire state's population should be about the same as the percentage of urban wood waste located in that MSA. This correlation was used to estimate the amount of urban wood waste located in MSAs for each utility service territory represented in the DISPERSE model. It is assumed that industrial facilities located in these metropolitan statistical areas would be able to access urban wood waste with an average transportation distance of 10-25 miles.

The estimated amount of urban wood waste in each utility service territory (taken by adding up the estimates for urban wood waste resources in each MSA within the territory) was used to limit the potential capacity for each utility. This is a more refined and accurate approach compared to the statelevel analysis used in the 2006 report that only considered total state urban wood waste resources as a limiting factor.

As with the forest residue analysis, pulp and paper mills and wood manufacturing plants are not considered because of their on-site wood waste resources and the propensity to economically utilize them. Other sites with CHP potential are cross-referenced with a database of known biomass CHP installations ${ }^{215}$ and eliminated if necessary.

\subsubsection{Results for Industrial Facilities, Not Including Power Export}

Industrial facilities and hospitals located close to urban wood waste resources can potentially benefit from installing a biomass boiler/steam turbine CHP system. Since urban wood waste can typically be obtained at a lower cost than forest residues, and urban wood waste resources are located close to population

\footnotetext{
214 Ibid.

${ }^{215}$ ICF International, Combined Heat and Power Installation Database, 2013, http://www.eea-inc.com/chpdata/
} 
centers (more likely to be located close to end-users), the economics for potential CHP projects are improved compared to forest residues. Overall, there is an estimated $734 \mathrm{MW}$ of economic potential when average transportation distances are 25 miles, or $950 \mathrm{MW}$ if transportation distances of 10 miles can be obtained. These estimates do not include wood products or pulp and paper mills, which are treated in a special power exporting scenario. The optimistic estimate for economic market potential among other industrial facilities is mapped for the different states in Figure 44.

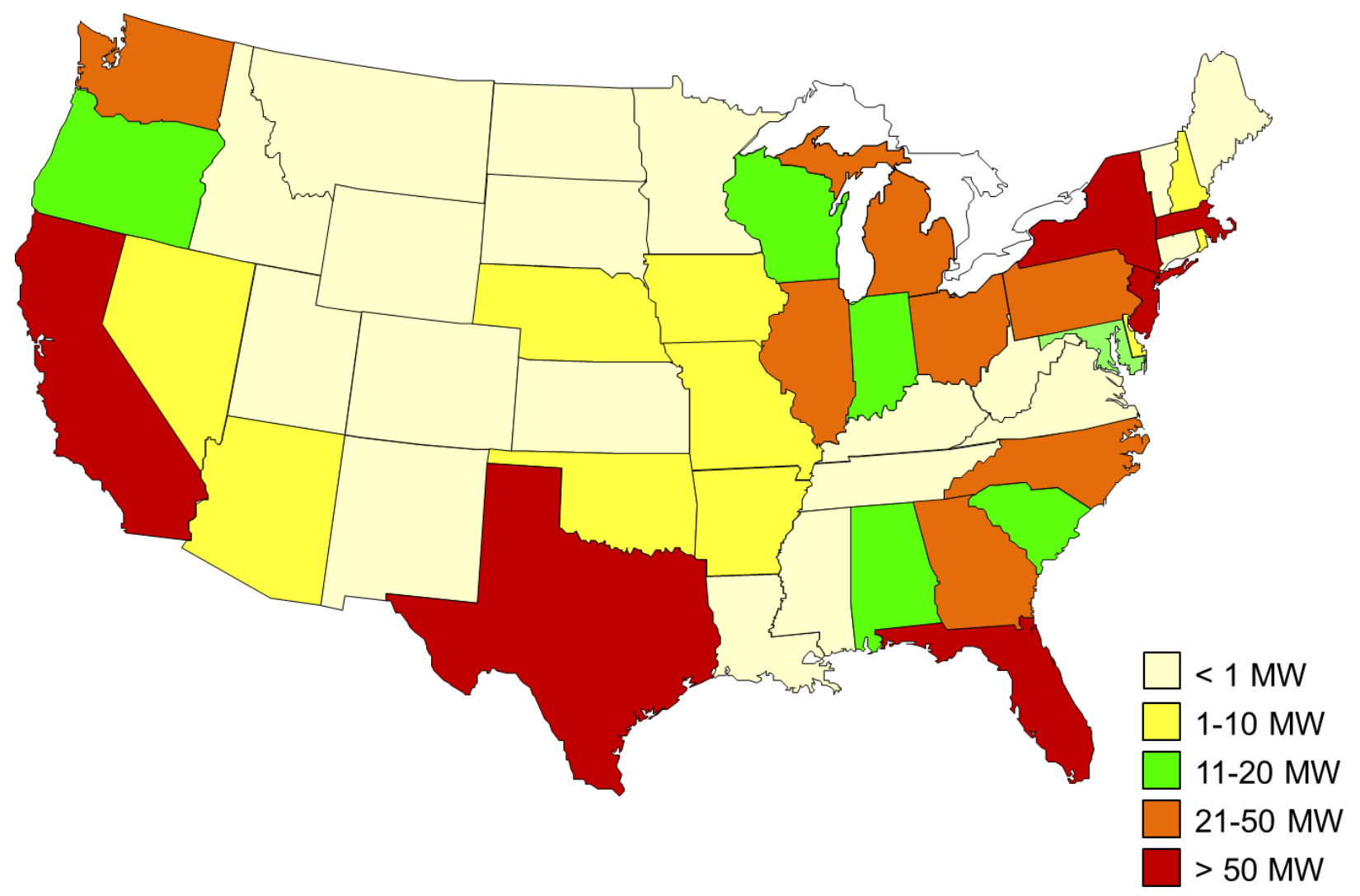

Figure 44. Economic Potential for Urban Wood Waste CHP Applications by State (Not Including Wood or Paper Products)

Not surprisingly, states with high-population areas tend to show the most potential for urban wood waste applications. In terms of both potential and economics, the top five metropolitan statistical areas to target are: New York City, Los Angeles, San Francisco, Chicago, and Boston. Urban areas in Texas, Florida and other parts of the country may have a large amount of resources and potential sites, but economics are generally not as favorable.

The optimistic economic potential is broken down by facility type in Figure 45. 


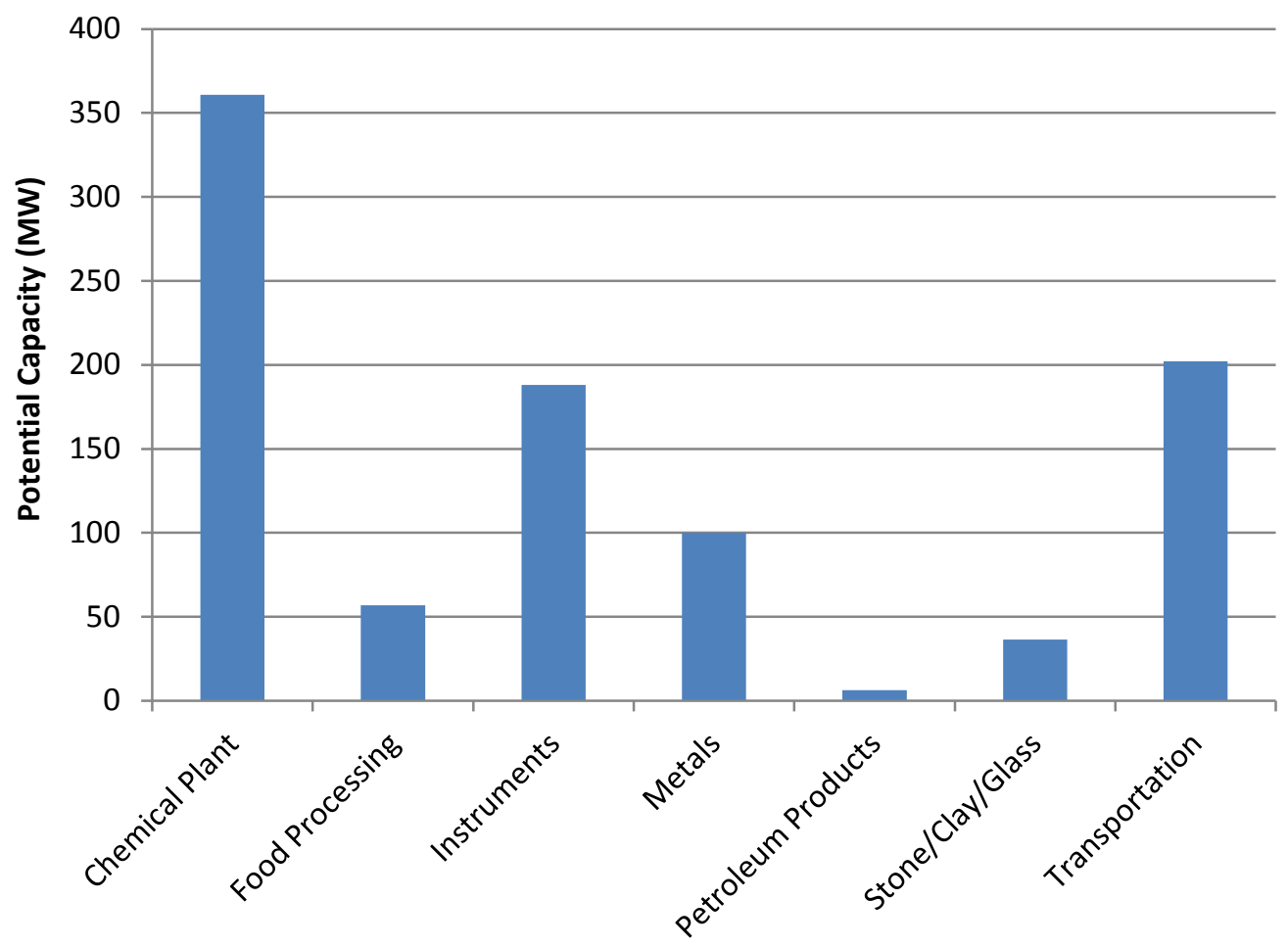

Figure 45. Economic Potential for Urban Wood Waste CHP Applications, by Facility Type (Optimistic Estimate, Not Including Wood or Paper Products)

All of these facilities have substantial thermal loads that can be met with steam production, and sufficient electric demand to support combined heat and power. For most of these projects, payback periods can be expected to fall between 4 and 6 years, but there are some exceptions. Payback period ranges for both the 10-mile and 25-mile average transportation distance are broken down in Figure 46. 


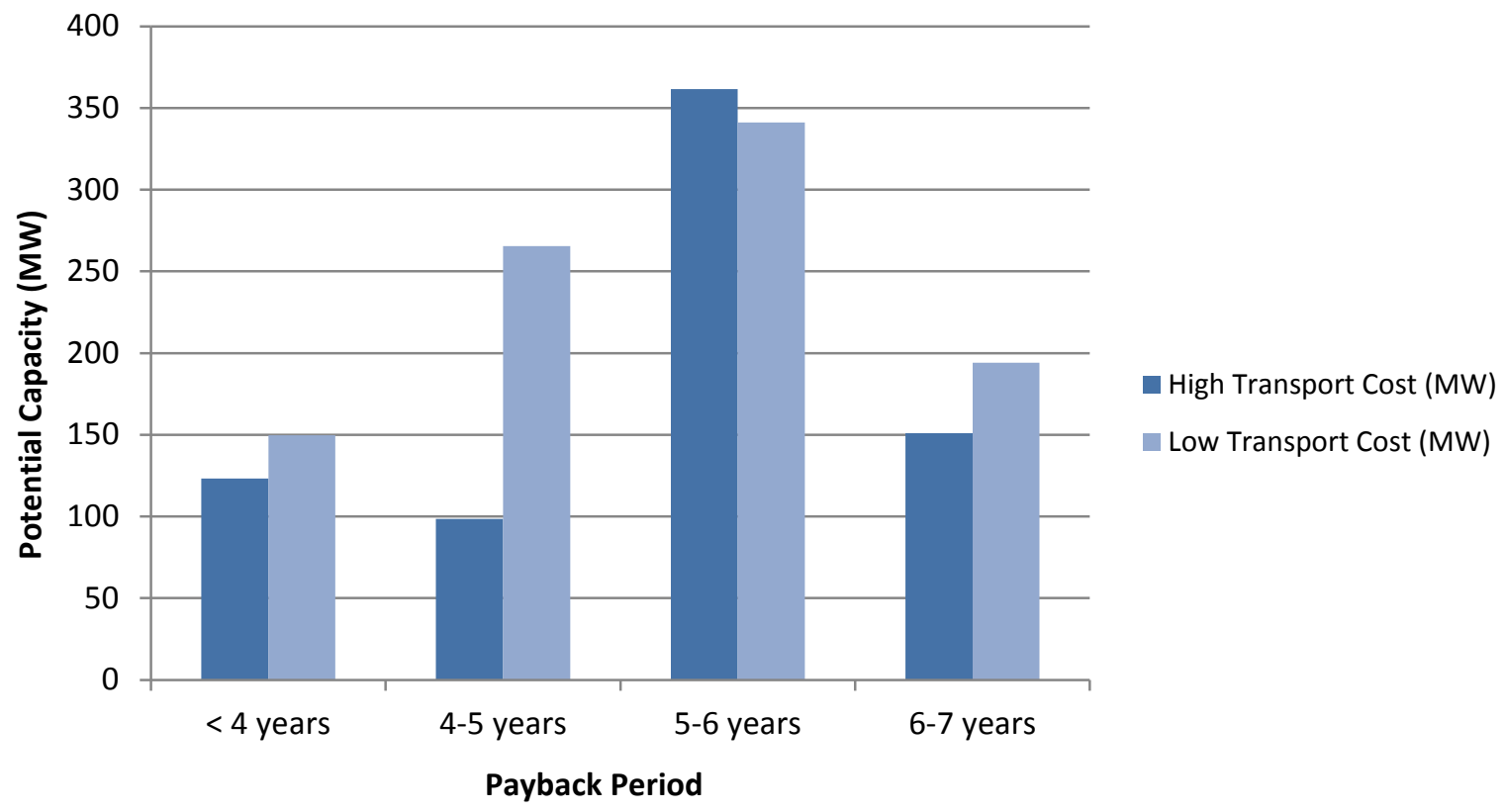

Figure 46. Payback Period Ranges for Urban Wood Waste CHP Applications

(Not Including Wood or Paper Products)

Several sites are estimated to be able to obtain payback periods of five years or less with urban wood waste. Table 25 shows the facilities with paybacks under five years when assuming a 10-mile average transportation distance. Most of the sites with the lowest payback periods reside in the Northeast. 
Table 25. Industrial Sites with Wood Waste CHP Payback Periods of Five Years or Less (10-mile transport, no Wood or Paper Products)

\begin{tabular}{|c|c|c|c|c|c|c|c|c|c|}
\hline Facility Type & State & Utility & $\begin{array}{c}\text { Estimated } \\
\text { Facility Size } \\
(\mathrm{kW})\end{array}$ & $\begin{array}{c}\text { CHP size } \\
\text { (kW) }\end{array}$ & $\begin{array}{c}\text { Applicable } \\
\text { Facilities }\end{array}$ & $\begin{array}{c}\text { Extraction or } \\
\text { Back- } \\
\text { Pressure? }\end{array}$ & $\begin{array}{c}\text { Annual } \\
\text { Electricity } \\
\text { (MWh) }\end{array}$ & $\begin{array}{c}\text { Annual } \\
\text { Fuel Used } \\
\text { (MMBtu) }\end{array}$ & $\begin{array}{c}\text { PayBack } \\
\text { (years) }\end{array}$ \\
\hline Petroleum Products & Hawaii & Hawaiian Electric & 13,950 & 6,220 & 1 & Extraction & 54,500 & 929,500 & 3.2 \\
\hline Chemicals & New York & LIPA & 50,930 & 23,300 & 1 & Back-Pressure & 203,900 & $6,957,400$ & 3.3 \\
\hline Food Processing & New Hampshire & Pub Serv NH & 3,210 & 1,240 & 1 & Back-Pressure & 10,900 & 370,900 & 3.4 \\
\hline Food Processing & New Hampshire & Pub Serv NH & 3,210 & 1,240 & 1 & Back-Pressure & 10,900 & 370,900 & 3.4 \\
\hline Chemicals & Massachusetts & National Grid & 62,830 & 28,700 & 1 & Extraction & 251,500 & $4,291,200$ & 3.4 \\
\hline Chemicals & New York & Con Edison & 50,930 & 23,300 & 1 & Back-Pressure & 203,900 & $6,957,400$ & 3.4 \\
\hline Chemicals & New York & Central Hudson & 17,240 & 7,880 & 1 & Back-Pressure & 69,000 & $2,354,900$ & 3.5 \\
\hline Transportation & Massachusetts & National Grid & 43,910 & 14,500 & 2 & Extraction & 10,900 & 741,800 & 3.6 \\
\hline Food Processing & Massachusetts & National Grid & 3,210 & 1,240 & 2 & Back-Pressure & 126,500 & $4,318,100$ & 3.6 \\
\hline Chemicals & Florida & Florida Power & 26,420 & 12,100 & 1 & Back-Pressure & 105,800 & $3,609,200$ & 3.8 \\
\hline Chemicals & Michigan & Detroit Edison & 27,670 & 12,600 & 1 & Back-Pressure & 110,800 & $3,780,200$ & 3.9 \\
\hline Stone/Clay/Glass & Rhode Island & Narragansett & 3,810 & 1,630 & 1 & Back-Pressure & 14,300 & 488,000 & 4.0 \\
\hline Chemicals & New York & Con Edison & 17,240 & 7,880 & 2 & Back-Pressure & 69,000 & $4,709,900$ & 4.0 \\
\hline Instruments & New Jersey & PSEG & 55,160 & 18,700 & 2 & Back-Pressure & 150,300 & $10,253,900$ & 4.0 \\
\hline Chemicals & New York & National Grid & 17,240 & 7,880 & 1 & Back-Pressure & 69,000 & $2,354,900$ & 4.3 \\
\hline Primary Metals & Pennsylvania & West Penn Power & 27,350 & 11,100 & 1 & Back-Pressure & 97,000 & $3,310,900$ & 4.6 \\
\hline Instruments & Washington & Puget Sound & 55,160 & 18,700 & 1 & Back-Pressure & 150,300 & $5,127,000$ & 4.6 \\
\hline Stone/Clay/Glass & New Jersey & PSEG & 3,150 & 1,350 & 1 & Back-Pressure & 11,800 & 402,700 & 4.6 \\
\hline Instruments & Rhode Island & Nagarransett & 2,050 & 1,050 & 1 & Back-Pressure & 8,500 & 288,400 & 4.7 \\
\hline Transportation & California & San Diego G\&E & 29,460 & 14,450 & 2 & Extraction & 126,500 & $4,318,100$ & 4.7 \\
\hline Primary Metals & Ohio & Cleveland Illum & 16,270 & 11,080 & 1 & Back-Pressure & 97,000 & $3,310,900$ & 4.7 \\
\hline Instruments & California & LADWP & 36,460 & 18,700 & 2 & Back-Pressure & 150,300 & $10,253,900$ & 4.8 \\
\hline Chemicals & Delaware & Delmarva & 1,990 & 1,680 & 1 & Back-Pressure & 14,700 & 501,600 & 4.8 \\
\hline Food Processing & Florida & Florida Power & 1,970 & 1,240 & 2 & Back-Pressure & 10,900 & 741,800 & 4.8 \\
\hline Chemicals & South Carolina & SC Pub Serv Auth & 16,190 & 13,630 & 1 & Extraction & 119,400 & $2,036,400$ & 4.8 \\
\hline Chemicals & Rhode Island & Nagarransett & 1,480 & 1,250 & 2 & Back-Pressure & 10,900 & 745,400 & 4.8 \\
\hline Transportation & California & LADWP & 28,070 & 13,760 & 1 & Extraction & 120,600 & $2,056,700$ & 4.8 \\
\hline Transportation & Connecticut & Connecticut L\&P & 29,460 & 14,450 & 2 & Extraction & 126,500 & $4,318,100$ & 4.9 \\
\hline Food Processing & Pennsylvania & PP\&L & 1,970 & 1,240 & 1 & Back-Pressure & 10,900 & 370,900 & 4.9 \\
\hline Instruments & California & Pacific G\&E & 36,460 & 18,700 & 1 & Back-Pressure & 150,300 & $5,127,000$ & 4.9 \\
\hline Chemicals & Florida & Florida P\&L & 14,350 & 12,070 & 1 & Back-Pressure & 105,800 & $3,609,200$ & 5.0 \\
\hline & & Totals & 698,800 & 322,860 & 40 & & $2,772,600$ & $99,007,200$ & \\
\hline
\end{tabular}

\subsubsection{Special Case: Power Exporting with Pulp and Paper Mills, Wood Product Manufacturers}

As with forest residues, a special case was evaluated for pulp and paper mills and wood products. These facilities tend to utilize their biomass waste fuels on-site, but there could be room for larger powerexporting CHP systems that would provide benefits for both the industrial facilities and the utilities that serve them. See page 6-25 for a discussion on this topic as it relates to forest residues. The only different variable here is the source of additional fuels for the oversized CHP systems, although it is possible that a 
combination of fuels could be used. In fact, some of the systems that have recently been deployed use a combination of forest residues and urban wood waste resources, in addition to on-site mill residues.

This analysis was treated in the same way as the special case for forest residues, except that urban wood waste resources are less expensive as well as less plentiful. Overall, there is an estimated $281 \mathrm{MW}$ of additional economic potential for urban wood waste to be utilized at up to 26 pulp and paper mills with power-exporting CHP systems. The same potential was found when using transportation distances of 10 and 25 miles, although economics suffered slightly with longer distances. Payback periods were in the range of 6-10 years, which is in the realm of acceptability for many utility companies. Combined with forest residues, the total economic potential for new pulp and paper mill CHP installations is estimated at up to $1.3 \mathrm{GW}$.

Some states with large pulp and paper mills and plentiful urban wood waste resources do not show up in the results because the wood waste could be economically utilized by other industrial facilities at lower payback periods compared to these utility projects. To avoid double-counting, urban wood waste resources that could be economically utilized by other industrial sites (as found in the initial market analysis) are not included in the pool of potential resources for pulp and paper mills. The results are summarized in Table 26.

Table 26. Economic Potential for New CHP Installations at Pulp and Paper Mills using Urban Wood Waste and Mill Resources

\begin{tabular}{|l|c|c|}
\hline $\begin{array}{l}\text { States with } \\
\text { Available } \\
\text { Urban Wood } \\
\text { Waste }\end{array}$ & $\begin{array}{c}\text { Economic } \\
\text { Potential } \\
\text { (MW) }\end{array}$ & $\begin{array}{c}\text { Maximum } \\
\text { Number of } \\
\text { Installations* }\end{array}$ \\
\hline Virginia & 84 & 7 \\
\hline Minnesota & 49 & 7 \\
\hline Tennessee & 42 & 4 \\
\hline Oregon & 37 & 3 \\
\hline Iowa & 19 & 1 \\
\hline Indiana & 15 & 1 \\
\hline Wisconsin & 13 & 1 \\
\hline New Mexico & 12 & 1 \\
\hline South Carolina & 10 & 1 \\
\hline United States & 281 & 26 \\
\hline
\end{tabular}

*Based on number of mills and 10 MW minimum size

The economic potential for urban wood waste, from pulp and paper mills as well as all other industries, is broken down in Figure 47. 


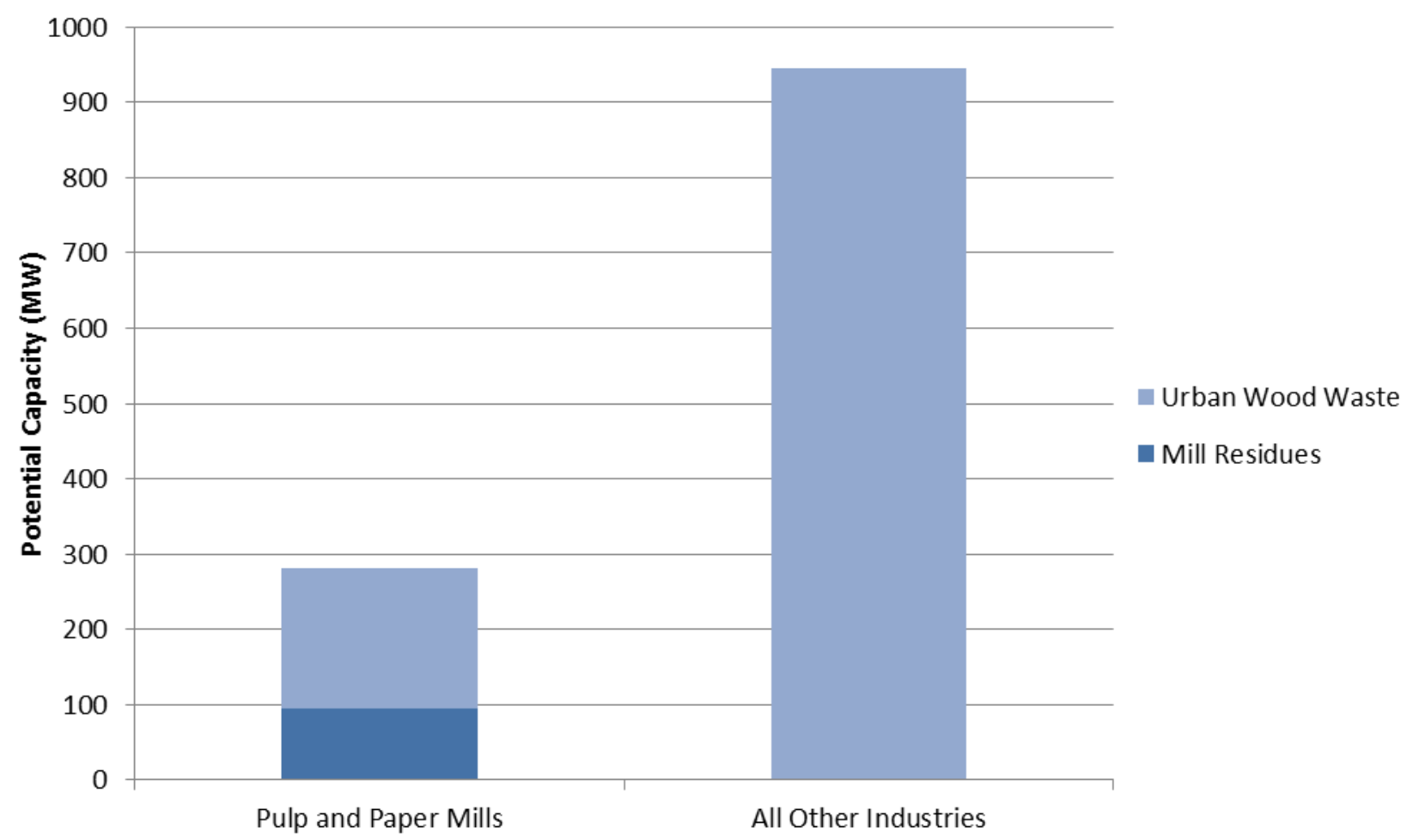

Figure 47. Economic Potential for CHP from Urban Wood Waste with CHP Power Export Scenario (Optimistic Estimates)

A sensitivity analysis was performed to determine how the economic potential would increase if utilities were replacing mill-produced electricity, selling a large portion of power from the new CHP systems at a discounted rate, higher than the wholesale rate that was previously assumed.

\subsubsection{Sensitivity: Replacing Mill-Produced Electricity}

Some pulp and paper mills use their power boilers to produce electricity with extraction steam turbines. For these facilities, at least some of the electricity from a new oversized CHP system would be replacing electricity that was previously produced on-site. Under the utility ownership scenario, all of the electricity and steam produced by the CHP system would belong to the utility. Paper mills may be reluctant to replace on-site electricity with purchased power, but utilities could potentially offer a substantial discount. For typical pulp and paper mills, about half of the electricity generated from the new oversized steam turbine would be replacing electricity that was previously produced on-site. ${ }^{216}$

An internal analysis showed that large paper mills tend to pay about 15 percent less than the state average industrial electricity price. An additional 20 percent discount was applied to this figure for each state, for half of the electricity sales from the new CHP unit. The other half of electricity sales are valued at the wholesale rate, as in the base case analysis. Because the details of paper mill power production are unknown, this scenario was applied to all potential pulp and paper mill CHP installations, resulting in improved economics from the utility's perspective.

${ }^{216}$ This assumes that the pulp and paper mill follows the configuration outlined in Figure 39, with the power boiler fueling an extraction turbine. 
Approximately 314 MW of CHP urban wood waste potential could be realized if all of the pulp and paper mills are currently utilizing extraction turbines to produce some of their own power. This is not a drastic improvement compared to the $244 \mathrm{MW}$ of potential found in the base case scenario. Again, the analysis assumes that urban wood waste resources are first allocated to industrial facilities with successful CHP economics, so the pool of resources for pulp and paper mills is fairly limited.

\subsubsection{Summary: Urban Wood Waste}

Urban wood waste is arguably the most promising opportunity fuel that can be used economically for CHP in areas with high population densities. The majority of potential came from backpressure steam turbines in the 10-20 MW size range, but there is substantial potential for smaller 1-10 MW systems. In addition, a few sites in New York, California and Texas were able to support boiler-steam turbine systems producing more than $20 \mathrm{MW}$, and some large pulp and paper mills could potentially support similarlysized projects. In total, there is an estimated 1-1.2 GW of potential capacity for urban wood waste utilization at industrial facilities.

\subsection{SUMMARY}

There is between 1.6 and 3.4 GW of economic potential for opportunity fuels in the United States. Figure 48 shows the estimated potential by fuel type, based on the optimistic estimates. The most potential lies with solid biomass boiler-steam turbine applications at large industrial facilities, with over 2.9 GW of combined potential from forest residues and urban wood waste using optimistic fuel transportation assumptions. Anaerobic digester gas and landfill gas projects are capable of supporting up to $480 \mathrm{MW}$ of opportunity-fueled CHP.

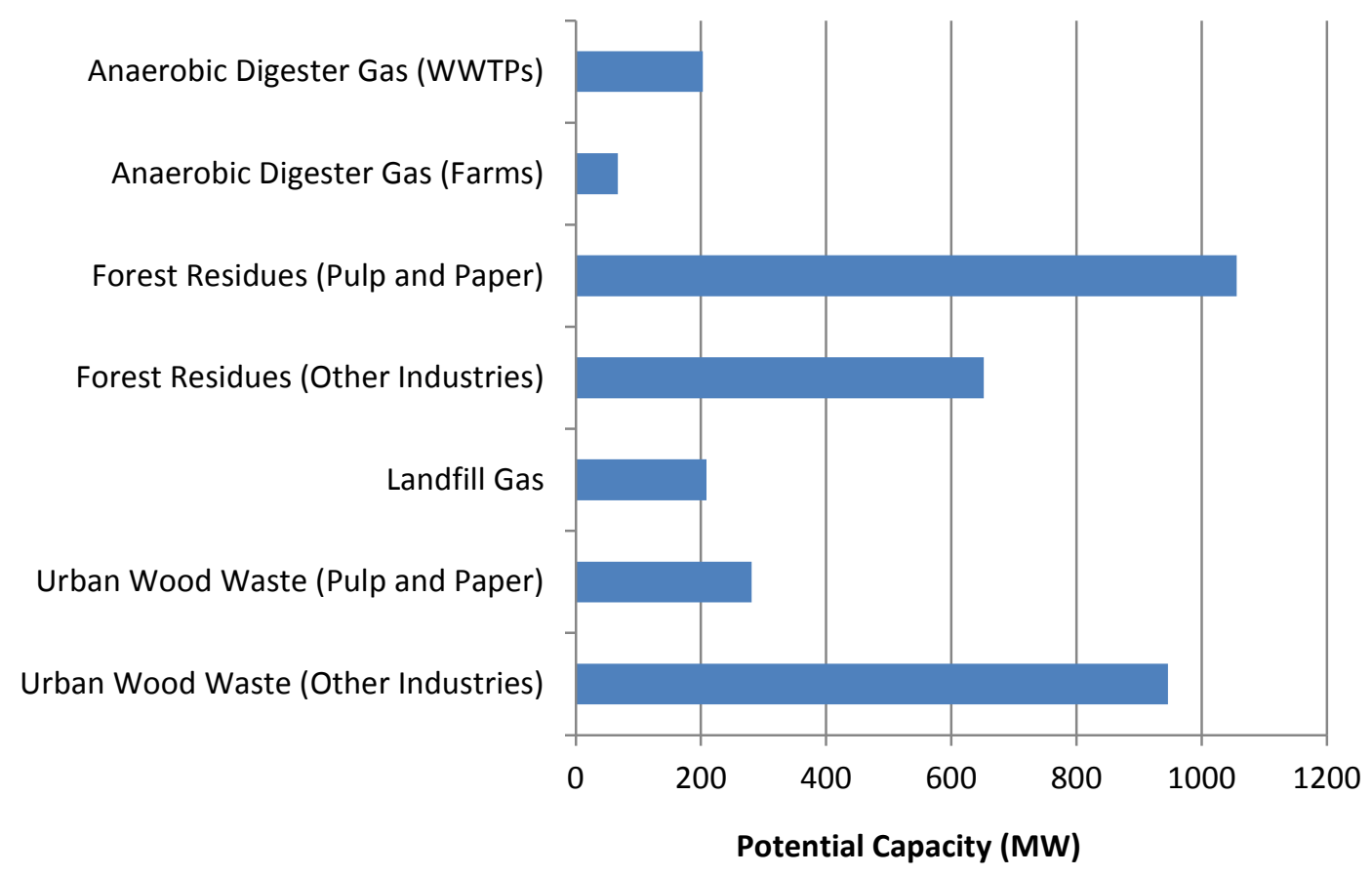

Figure 48. CHP Market Potential by Fuel Type (Optimistic Estimates) 
California has the most potential for CHP opportunity fuel applications, with between 360 and 490 MW of potential capacity. Following California are Virginia and North Carolina, which have a combined potential of up to $540 \mathrm{MW}$, primarily due to potential paper mill CHP installations. However, the conservative estimates (assuming longer transportation distances) are not nearly as high, at just $80 \mathrm{MW}$ of combined potential for the two states. Similarly, the economic potential in Texas could range anywhere between 20 and $250 \mathrm{MW}$, depending heavily on average biomass transportation distances. Washington and Oregon show a great deal of potential, especially for CHP applications at pulp and paper mills, but again they are dependent on relatively short transportation distances for biomass fuel resources. Florida, Pennsylvania, and New York show strong potential under both the optimistic and conservative scenarios, so projects in these states (along with California) have a better chance of handling unexpected setbacks related to fuel acquisition or other project finances.

The total market potential for each state is plotted on the map in Figure 49, using the optimistic estimates. A breakdown of the economic market potential by CHP Technical Assistance Partnership region and facility type is provided in Appendix C.

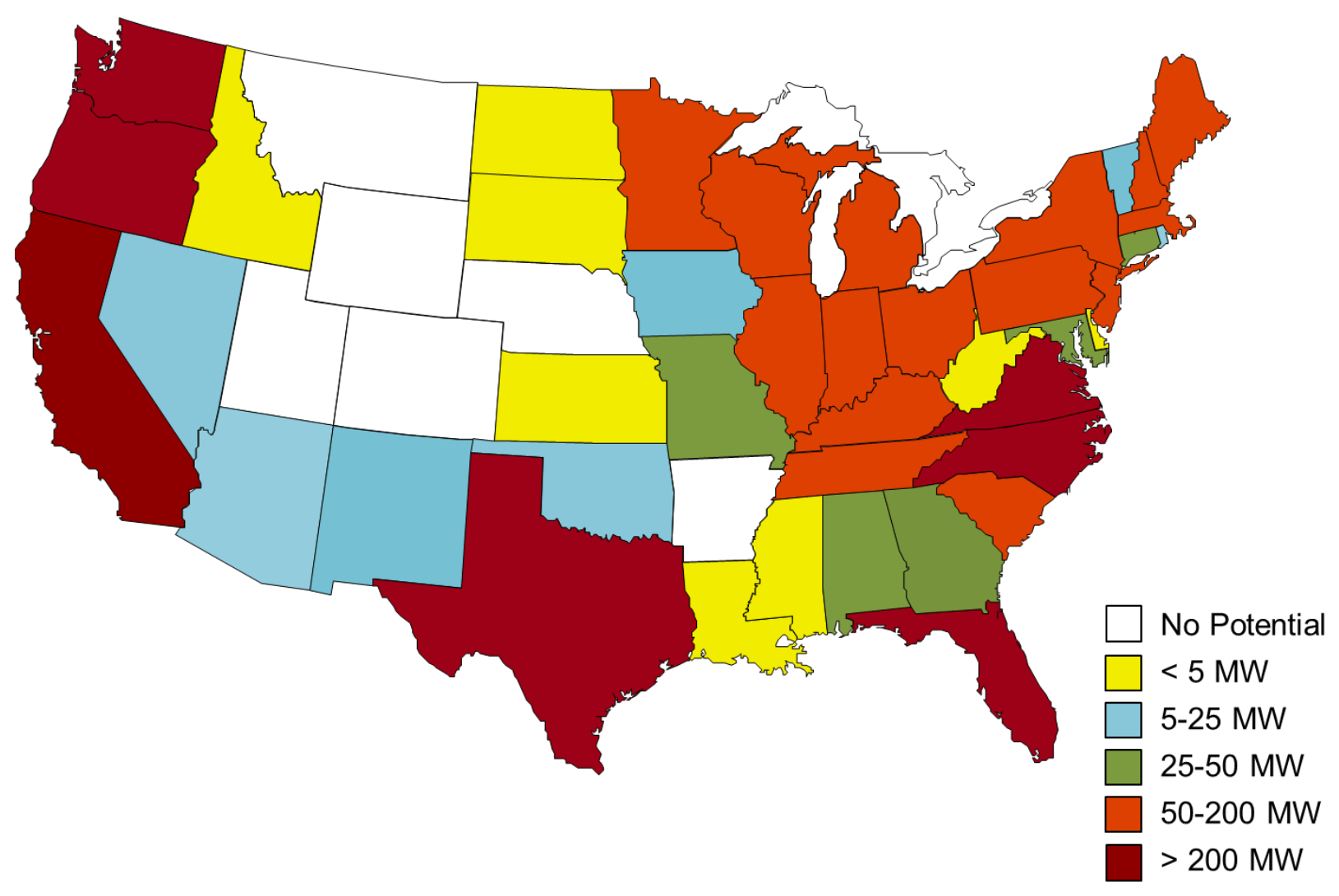

Figure 49. Estimated Potential for All Opportunity Fuels, by State

The economic potential depends on economic conditions within the state (utility prices for electricity and gas) as well as available opportunity fuel resources. This analysis included the Federal Investment Tax Credit for CHP (10\% of the system cost), but it did not include any state-specific incentives that could potentially improve the economics for opportunity fuel CHP projects. 
APPENDIX A. DISPERSE MODEL METHODOLOGY 



\section{APPENDIX A. DISPERSE MODEL METHODOLOGY}

The analysis of opportunity fuel CHP systems was performed using the DIStributed Power Economic Rationale SElection (DISPERSE) model ${ }^{217}$. This spreadsheet-based model can estimate the achievable economic potential for distributed generation systems by comparing the cost to obtain, operate, and maintain the CHP system with the cost of utility heat and power. The model determines which combination of size, rate schedule, and operating mode is the most economical for a given application. Figure 50 illustrates how the DISPERSE model organizes the key data inputs and generates the desired outputs.

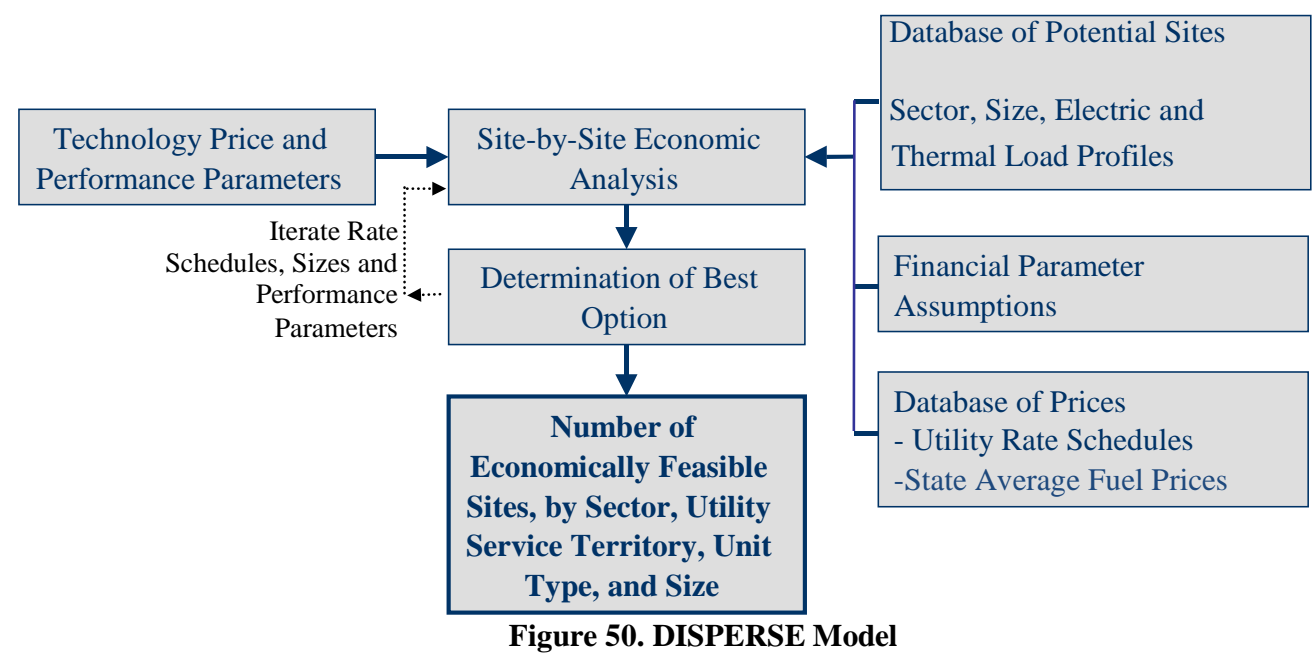

The DISPERSE model has been developed over the past twenty years, and has been applied to a variety of projects for utilities, equipment manufacturers, and research organizations.

\section{DISPERSE MODEL: KEY INPUTS AND ASSUMPTIONS}

The DISPERSE model performs a life-cycle cost economic analysis, based on the estimated unit life, fuel expenses, cost and performance data, electric utility rate schedules, and monthly average state fuel prices. The model determines whether any CHP technology option can beat the case in which all electricity and natural gas is purchased from the local utilities. The best technology option for a given application is selected based on the shortest payback period.

The following key inputs are used by the model:

1. Technology price and performance parameters. The model requires data on the mix of technologies that are being analyzed. This data includes each technology's installed cost, heat rate, electrical efficiency, usable thermal output, operating and maintenance costs, and other key parameters. These estimates were obtained by collecting data from equipment manufacturers, case studies, and industry experts.

\footnotetext{
${ }^{217}$ Resource Dynamics Corporation, DIStributed Power Economic Rationale Selection (DISPERSE) Model. McLean, Virginia, 2013.
} 
The estimated installed costs for opportunity fuel CHP have increased considerably from the 2006 analysis, primarily due to higher estimates for fuel pretreatment equipment, including siloxane and hydrogen sulfide removal for gaseous fuels, and biomass fuel preparation for boiler/steam turbine systems. The installed cost estimates for ADG and LFG in 2006 and 2013 are provided in Figures 51 and 52. Costs for boiler/steam turbine systems were not comparable as back-pressure and extraction turbines were analyzed in the 2013 analysis.

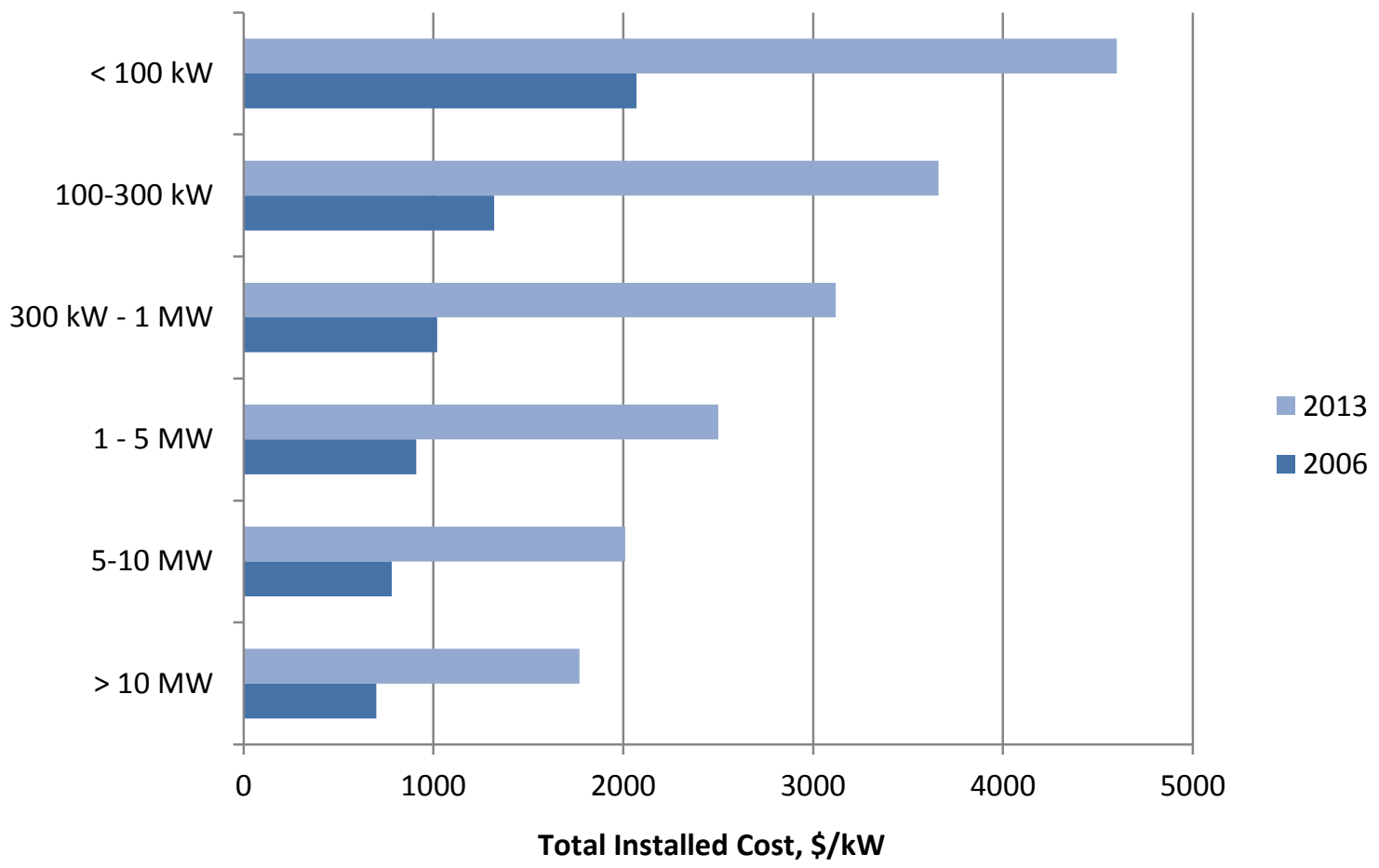

Figure 51. Installed Costs for ADG/LFG Engines, 2006 and 2013 


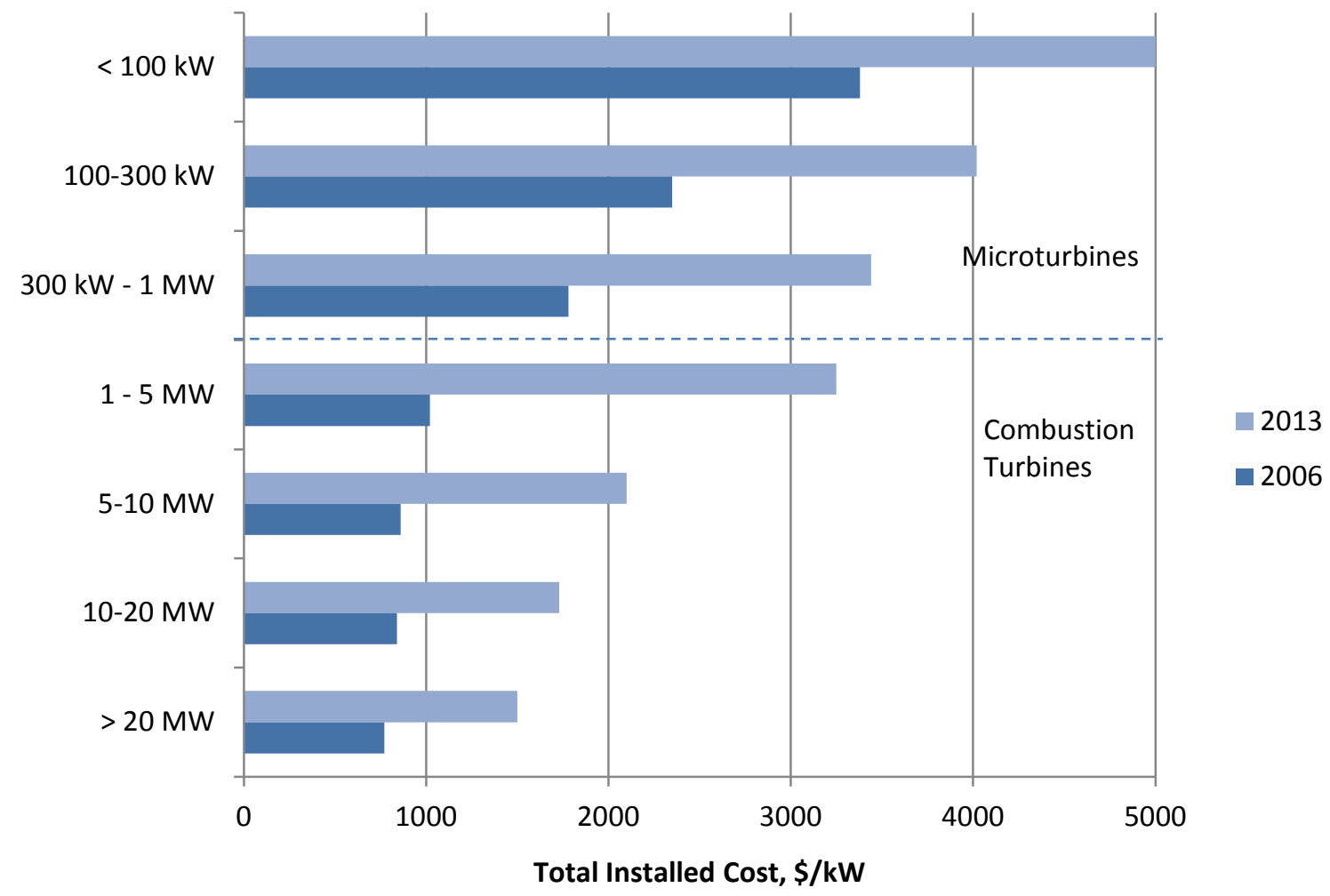

Figure 52. Installed Costs for ADG/LFG Turbines, 2006 and 2013

2. Building characteristics Load profiles for building types used in the analysis were generated using DOE2 building models and average weather data. Industrial load profiles are generated from data collected by the contractor and simplified 24-hour load profiles that can be adjusted for different facility sizes based on the number of employees.

3. Database of fuel prices. Natural gas costs are based on state average 2011 prices for the industrial sector, by month, as reported by the DOE’s Energy Information Administration (EIA).

4. Database of grid prices. Commercial, industrial and residential rate schedules were identified and modeled for prominent utilities in nearly every state, including options for time-of-use and demand-based rates. Electricity rates vary based on location and building load profiles.

5. Financial parameter assumptions. A maximum project life of 10 years is assumed, reflecting the anticipated life of smaller CHP projects and conservative financial planning from customers. The installed cost of the system, maintenance costs, and fuel costs are the primary variables, along with the calculated electricity costs for the building before and after CHP is installed. Simple payback periods are calculated for all projects, and those with paybacks of less than seven years are generally considered to have economic potential. 


\section{DETERMINING THE MOST ECONOMIC CHP OPTION}

The DISPERSE model estimates the most economic technology and unit size that can be used for baseload operation for a particular building type. To do so, the payback period for various CHP systems versus grid electricity and local natural gas prices is calculated. That is, the economics of either utilizing CHP or purchasing adequate electricity and natural gas to meet consumption needs is estimated for each combination of building size/type and CHP technology size/type. In each case, one technology will offer the most attractive project economics, which may or may not be preferable to utility-purchased electricity and gas. 
APPENDIX B. DETAILED MARKET POTENTIAL BY FUEL, FACILITY TYPE AND TAP REGION 



\section{APPENDIX B. DETAILED MARKET POTENTIAL BY FUEL, FACILITY TYPE AND TAP REGION}

In this Appendix, the potential is broken down by facility type and CHP Technical Assistance Partnership Region for each fuel (see Figure 53). For all cases, the optimistic set of assumptions were used.

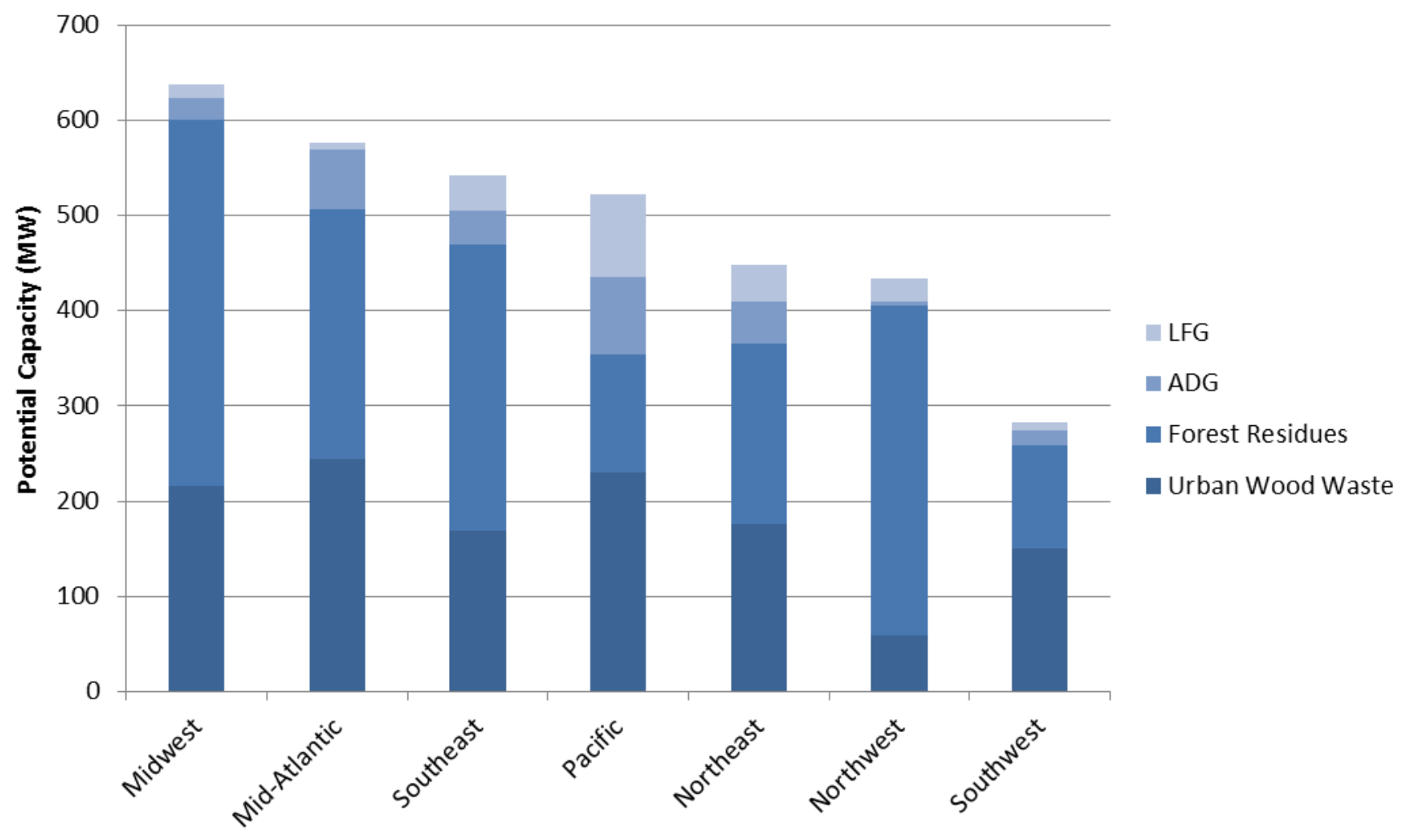

Figure 53. . Opportunity Fuel Market Potential by TAP Region 
Table 27. Market Potential for ADG CHP by Facility Type and TAP Region

\begin{tabular}{|c|c|c|c|c|c|c|c|}
\hline \multirow[b]{2}{*}{ Facility Type } & \multicolumn{7}{|c|}{ Potential Capacity (MW) } \\
\hline & Northeast & Mid-Atlantic & Southeast & Midwest & Southwest & Pacific & Northwest \\
\hline Muncipal WWTPs & 40 & 62 & 33 & 21 & 16 & 16 & 5 \\
\hline Industrial WWTPs & 4 & 0 & 3 & 0 & 0 & 1 & 0 \\
\hline Dairy Farms & 0 & 1 & 0 & 2 & 0 & 65 & 0 \\
\hline All Sectors & 44 & 63 & 36 & 23 & 16 & 82 & 5 \\
\hline
\end{tabular}

Table 28. Market Potential for LFG CHP by Facility Type and TAP Region

\begin{tabular}{|c|c|c|c|c|c|c|c|}
\hline \multirow[b]{2}{*}{ Facility Type } & \multicolumn{7}{|c|}{ Potential Capacity (MW) } \\
\hline & Northeast & Mid-Atlantic & Southeast & Midwest & Southwest & Pacific & Northwest \\
\hline Food Processing & 2 & 3 & 21 & 0 & 0 & 47 & 24 \\
\hline Pulp and Paper & 0 & 0 & 11 & 7 & 8 & 5 & 0 \\
\hline Chemicals & 24 & 0 & 2 & 0 & 0 & 21 & 0 \\
\hline Petroleum Products & 0 & 2 & 0 & 0 & 0 & 11 & 0 \\
\hline Rubber and Plastics & 0 & 2 & 0 & 0 & 0 & 0 & 0 \\
\hline Primary Metals & 13 & 0 & 0 & 0 & 0 & 3 & 0 \\
\hline Metal Products & 0 & 0 & 3 & 0 & 0 & 0 & 0 \\
\hline Transportation Equipment & 0 & 0 & 0 & 6 & 0 & 0 & 0 \\
\hline All Sectors & 39 & 7 & 37 & 13 & 8 & 86 & 24 \\
\hline
\end{tabular}


Table 29. Market Potential for CHP from Forest Residues, by Facility Type and TAP Region

\begin{tabular}{|l|r|r|r|r|r|r|r|}
\cline { 2 - 8 } \multicolumn{1}{c|}{} & \multicolumn{9}{c|}{ Potential Capacity (MW) } \\
\hline Facility Type & Northeast & Mid-Atlantic & Southeast & Midwest & Southwest & \multicolumn{1}{c|}{ Pacific } & Northwest \\
\hline Food Processing & 12 & 8 & 4 & 5 & 0 & 3 & 0 \\
\hline Pulp and Paper & 54 & 187 & 189 & 154 & 109 & 84 & 279 \\
\hline Chemicals & 21 & 14 & 34 & 25 & 0 & 0 & 31 \\
\hline Stone/Clay/Glass & 2 & 2 & 0 & 2 & 0 & 0 & 0 \\
\hline Primary Metals & 6 & 57 & 11 & 11 & 0 & 0 & 17 \\
\hline Transportation Equipment & 37 & 29 & 98 & 14 & 0 & 0 & 0 \\
\hline Instruments & 58 & 2 & 75 & 19 & 0 & 37 & 19 \\
\hline All Sectors & 190 & 298 & 411 & 229 & 109 & 124 & 0 \\
\hline
\end{tabular}

Table 30. Market Potential for Urban Wood Waste CHP, by Facility Type and TAP Region

\begin{tabular}{|c|c|c|c|c|c|c|c|}
\hline \multirow[b]{2}{*}{ Facility Type } & \multicolumn{7}{|c|}{ Potential Capacity (MW) } \\
\hline & Northeast & Mid-Atlantic & Southeast & Midwest & Southwest & Pacific & Northwest \\
\hline Food Processing & 10 & 20 & 10 & 5 & 4 & 9 & 0 \\
\hline Pulp and Paper & 0 & 84 & 52 & 96 & 12 & 0 & 37 \\
\hline Chemicals & 116 & 20 & 71 & 43 & 111 & 0 & $\underline{0}$ \\
\hline Petroleum Products & 0 & 0 & 0 & 0 & 0 & 6 & 0 \\
\hline Stone/Clay/Glass & 2 & 10 & 6 & 2 & 8 & 6 & 3 \\
\hline Primary Metals & 0 & 22 & 0 & 56 & 0 & 22 & 0 \\
\hline Transportation Equipment & 62 & 0 & 41 & 0 & 14 & 85 & 0 \\
\hline Instruments & 1 & 37 & 0 & 37 & 0 & 93 & 19 \\
\hline All Sectors & 191 & 194 & 180 & 238 & 150 & 221 & 58 \\
\hline
\end{tabular}


